\title{
SOCIĀLĀ \\ SPĒCINĀŠANA \\ rīcībspējai un pārmaiņām
}

Zinātniskā redaktore

Dr. phil. Anna Stepčenko

\section{SOCIAL} EMPOWERMENT for Capability and Changes

Report on SEMPRE project "Social Empowerment in Rural Areas" 


\section{SOCIĀLA \\ SPËCINĀŠANA \\ rīcībspējai un pārmaiñām}

Pārskats par projektu "Sociālā spēcināšana reǵionos" (SEMPRE) Interreg Baltijas jūras regiona transnacionālās teritoriālās sadarbības programmā 2014.-2020. gadam

\section{SOCIAL EMPOWERMENT for Capability and Changes}

Report on the Project "Social Empowerment in Rural Areas" (SEMPRE), Interreg Baltic Sea Region Transnational European Territorial Cooperation Programme 2014-2020 
Sociālā spēcināšana rīcībspējai un pārmaiṇām. Pārskats par projektu "Sociālā spēcināšana reǵionos" (SEMPRE) Interreg Baltijas jūras reǵiona transnacionālās teritoriālās sadarbības programmā 2014.-2020. gadam = Social Empowerment for Capability and Changes. Report on the Project "Social Empowerment in Rural Areas" (SEMPRE), Interreg Baltic Sea Region Transnational European Territorial Cooperation Programme 2014-2020. Rīga : LU Akadēmiskais apgāds, 2019. 212 lpp.

SEMPRE projektu finansē Eiropas Regionālās attīstības fonds un Latvijas Republikas Izglītības un zinātnes ministrija.

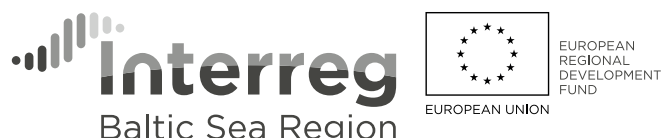

\section{SEMPRE .०}

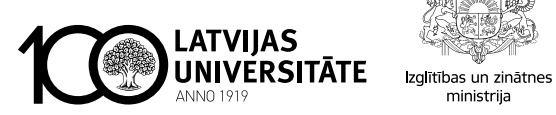

Publicēts saskaṇā ar LU Sociālo zinātṇu padomes sēdes lēmumu 2018. gada 13. decembrī (protokols Nr. 9).

Recenzenti:

Dr. phil. Signe Dobelniece, Latvijas Lauksaimniecības universitāte

Dr. $s c . s o c$. Ritma Rungule, Rīgas Stradiṇa universitāte

Mg. sc. educ. Gundi Šretere-Johansena (Gundi Schrötter Johannsen),

Dienviddānijas Universitātes koledža (University College South Denmark)

Zinātniskā redaktore Dr. phil. Anna Stepčenko

Literārā redaktore Ruta Puriṇa

Anglu teksta redaktore Andra Damberga

Maketētāja Andra Liepiṇa

Vāka noformējumā izmantots SEMPRE projekta dizains, kurā ir iezīmētas partnerïbas vietas.

Pārskats izstrādāts Latvijas Universitātes Sociālo zinātṇu fakultātes Sociālo un politisko pētījumu institūtā.

ISBN 978-9934-18-393-5

(C) Latvijas Universitāte, 2019

(C) Anna Stepčenko, Laura Jaunromāne, 2019

DOI: http://doi.org/10.22364/ssrp 


\section{Saturs}

SEMPRE projekta partneru, to atrašanās vietu un lokālās spēcināšanas tîklu vietu saraksts $\ldots \ldots \ldots \ldots \ldots \ldots \ldots$. 5

Sociālo pakalpojumu galalietotāju saraksts

SEMPRE projektā $\ldots \ldots \ldots \ldots \ldots \ldots \ldots \ldots \ldots \ldots \ldots \ldots \ldots, 7$

Akronīmu un saīsinājumu saraksts $\ldots \ldots \ldots \ldots \ldots \ldots \ldots \ldots, 8$

Terminu un jēdzienu skaidrojums un tulkojums $\ldots \ldots \ldots \ldots .10$

\section{Anna Stepčenko}

Ievads

Anna Stepčenko

Sociālā spēcināšana rīcībspējai un pārmaiṇām

\section{Anna Stepčenko, Laura Jaunromāne}

Iesaistî̌sana un iesaistǐšanās līdzdalībai pārmaiṇu procesā ......

\section{Anna Stepčenko}

Sociālekonomiskā konteksta salīdzinošā analīze

SEMPRE projekta spēcināšanas vietās

\section{Anna Stepčenko, Laura Jaunromāne}

Iesaistītās/ieinteresētās puses sociālo pakalpojumu

organizāciju personāla un pakalpojumu galalietotāju

spēcināšanā. Teorētisks ieskats un SEMPRE projekta

empirisko datu analīze

\section{Laura Jaunromāne}

Personu ar invaliditāti vajadzības Grobiṇas, Priekules, Rucavas novadā un Liepājā ...................... 139

1. pielikums. Politikas veidošanas dokumenti attiecībā uz personām ar invaliditāti ................. 199

2. pielikums. Likumi un MK noteikumi par personu ar invaliditāti tiesībām 



\section{SEMPRE projekta partneru, to atrašanās vietu un lokālās spēcināšanas tīklu vietu saraksts ${ }^{1}$}

1. Šlēsvigas-Holšteinas Diakonija, Rendsburga, Ditmāršene, Vācija (Diaconie of Schleswig-Holstein, Rendsburg, Dithmarschen, Germany).

2. Ziemel̦vācijas Evaṇgéliski luteriskā baznīca, Ķile, Plēne, Vācija (Evangelical Lutheran Church in Northern Germany, Kiel, Plön, Germany).

3. Šlēsvigas-Holšteinas Ekonomikas akadēmija, Ķile, Vācija (Academy of Economics Schleswig-Holstein, Kiel, Germany).

4. Lietišķo zinātṇu augstskola Novia, Ostrobotnija, Vāsa, Somija (Novia University of Applied Sciences, Ostrobothnia, Vaasa. Finland; somu val. Ammattikorkeakoulu Novia; zviedru val. Yrkeshögskolan Novia).

5. Jiveskiles-Kokolas Universitātes konsorcijs Chydenius, Ostrobotnija, Kokola, Somija (University of Jyväskylä, Kokkola University Consortium Chydenius, Ostrobothnia, Kokkola, Finland).

6. Talantu kalve, NVO, Rīga, Latvija (projekta partnerībā netika iekḷauta, bet tiek saglabāta partneru sarakstā) (Talent Forge, NGO, Riga, Latvia).

7. Liepājas Diakonijas centrs, Liepāja, Latvija (Diaconal Centre Liepaja, Liepaja, Latvia). Grobiņa, Bārta, Duben̦i, Rucava, Durbe.

8. Latvijas Universitāte, Rīga, Latvija (University of Latvia, Riga, Latvia).

9. Luterāṇu Diakonija, Jurbarka, Pageēgi, Viḷna, Lietuva (Lutheran Diaconia, Jurbarka, Pagégiai, Vilnius, Lietuva).

10. Igaunijas Evaṇgéliski luteriskā baznīca, Harkujerve, Tallina, Igaunija (Estonian Evangelical Lutheran Church, Harkujärve, Tallinn, Estonia).

Partneru secība sarakstā veidota saskaņā ar to secību projekta pieteikumā vai arī iesaistǐšanās laiku partnerībā. Ja lokālais spēcināšanas tīkls atrodas tajā pašā vietā, kur ir partnera rezidence, tad otrreiz vietas nosaukums netiek norādìts (A. S.). 
11. Sociālās rīcības fonds, Tallina, Ziemeḷaustrumigaunija (Foundation of Social Action, Tallinn, Northern-Eastern Estonia).

12. Mūžizglitīibas fonds PERITIA, Ričivola, Polija (The Foundation for Lifelong Learning PERITIA, Ryczywol, Poland). Polijas partneris darbu SEMPRE projektā pārtrauca 2018. gada 31. augustā.

13. Coompanion Norrbotten, Lūleo, Norbotenas regions, Zviedrija. Konsultatīva apvienība sociālās uzñēmējdarbības ekonomiskos jautājumos (Coompanion Norrbotten, Luleå, Sweden. Consulting Economical Association in Field of Social Entepreneurship).

14. Sanderbijas tautas vidusskola, Lūleo, Norbotenas regions, Zviedrija (Sunderby Folk High School, Luleå, Norrbotten, Sweden).

15. Dienviddānijas Universitātes koledža, Esbjerga, Tendere, Varde, Dānija (University College South Denmark, Esbjerg, Toender, Varde, Denmark).

16. Nordregio, Ziemel̦valstu Ministru padomes starptautiskais regionālās attīstības un plānošanas pētniecības centrs, Stokholma, Zviedrija (Nordregio, Nordic Council of Ministers' International Reserch Center for Regional Development and Planning, Stockholm, Sweden).

17. Vidzemes Augstskola, Vidzemes reg̣iona apdzīvotās vietas, Valmiera, Latvija (Vidzeme University of Applied Sciences, Valmiera, Latvia). 


\title{
Sociālo pakalpojumu galalietotāju saraksts SEMPRE projektā ${ }^{1}$
}

\author{
Bēgḷi (refugees), DK
}

Bēgli un migranti (refugees and migrants), DE

Ģimenes ar bērniem un vecāka gadagājuma personas (families with children and elderly), EE

Ilgstošie bezdarbnieki un vinu gimenes (long-term unemployed people and their families), DE

Jaunieši (15-29) bezdarbnieki ar zemu izglìtības līmeni, garīgās attīstìbas un uzvedības traucejumiem (disadvantaged youth, not in education, employment, or training (NEET), with intellectual disabilities, mental and social behavioral problems), LV

Jaunieši bezdarbnieki ar zemu izglitīibas un prasmju līmeni, kuri riskē būt ilgstoši bezdarbnieki (young people in lack of education and work in risk of becoming long-term unemployed), SE

Jaunieši laukos (11-25) (rural youth (11-25)), PL

Migranti ar pastāvīgās uzturēšanās aț̣aujām un patvēruma meklētāji (migrants with permanent residence permit and those applying for asylum), SE

Migranti, kas ir ilgstoši bezdarbnieki (long-term unemployed migrants), FI

No ieslodzijuma atbrīvotās personas un gimenes ar bērniem (exprisoners and families with children), EE

Pieaugušas personas ar garīgu un fizisku invaliditāti (people with mental and physical handicaps/disabilities), LV

Vecāka gadagājuma personas (65+) (older adults (65+)), FI

Viena vecāka gimenes (single parents), DE, LT

Viena vecāka gimenes un vielatkarīgas personas (single parents and persons suffering from addiction diseases), LT

\footnotetext{
Saraksts veidots alfabētiski, un tiek lietoti partneru sociālo pakalpojumu galalietotāju kategoriju nosaukumi, beigās norādot tās valsts simbolu, kuru tie pārstāv. Daži partneri ir spēcinājuši vairāku kategoriju sociālo pakalpojumu galalietotājus, arī tas minēts šai sarakstā (A. S.).
} 


\section{Akronīmu un saīsinājumu saraksts}

ANO - Apvienoto Nāciju Organizācija

b.g. / n.d. - atsaucēs lietots saīsinājums avotiem, kuros nav norādìts publicēšanas gads: bez gada (avotiem latviešu valodā) / no date (avotiem angḷu valodā)

DE - Vācija

DI - deinstitucionalizācija

DK - Dānija

EE - Igaunija

EPSPAIA - Eiropas Pakalpojumu sniedzēju asociācija personām ar invaliditāti (European Association of Service Providers for Persons with Disabilities (EASPD))

ESH - Eiropas Sociālā harta

FI - Somija

HIV/AIDS - cilvēka imūndeficīta vīruss / iegūtā imūndeficìta sindroms (Human Immunodeficiency Virus / Acquired Immunodeficiency Syndrome)

IA Pamatnostādnes - Izglìiības attīstības pamatnostādnes 2014.2020. gadam

ICT (information and communication technologies) - informācijas un komunikācijas tehnologijas

IT - informācijas tehnologijas

IZM - Izglìtības un zinātnes ministrija

"Latvija 2030" - Latvijas ilgtspējīgas attīstības stratēgija līdz 2030. gadam

LM - Labklājības ministrija

LT - Lietuva

LV - Latvija

MK - Ministru kabinets

"NAP 2020" - Latvijas Nacionālais attīstības plāns 2014.-2020. gadam

NEET (Not in Education, Employment, Training) - jaunieši, kas nemācās, nestrādā un neapgūst arodu

NVO - nevalstiska organizācija

PL - Polija 
PP - projekta partneris

PSRS - Padomju Sociālistisko Republiku Savienība

PVO - Pasaules Veselības organizācija

SAC - sociālās aprūpes centrs

SD Pamatnostādnes - Profesionālā sociālā darba attīstības pamatnostādnes 2014.-2020. gadam

SE - Zviedrija

SIF - Sabiedrības integrācijas fonds

SIVA - Sociālās integrācijas valsts ag̣entūra

SP Pamatnostādnes - Pamatnostādnes sociālo pakalpojumu attīstībai 2014.-2020. gadam

SPS - sociālo pakalpojumu sniedzēji

SV Pamatnostādnes - Sabiedrības veselỉbas pamatnostādnes 2014.2020. gadam

TA - tautas augstskola

TA Pamatnostādnes - Transporta attīstības pamatnostādnes 2014.2020. gadam

VDEAVK - Veselības un darbspēju ekspertīzes ārstu valsts komisija VM - Veselíbas ministrija 


\section{Terminu un jēdzienu skaidrojums un tulkojums}

Uzrādīti tie termini un jēdzieni, kas saistīti ar šī projekta tematisko saturu.

Asistents - fiziska persona, kas sniedz atbalstu personai ar smagas vai loti smagas pakāpes funkcionēšanas ierobežojumu tādu darbỉbu veikšanai ārpus mājokḷa, kuras tā invaliditātes dēḷ nevar veikt patstāvīgi (Saeima, 2010a) ${ }^{1}$.

Dienas aprūpes centrs - institūcija, kas dienas laikā nodrošina sociālās aprūpes un rehabilitācijas pakalpojumus, sociālo prasmju attīstību, izglītošanu un brīvā laika pavadīšanas iespējas personām ar garīga rakstura traucējumiem, invalīdiem, bērniem no trūcīgām ğimenēm un gimenēm, kurās ir bērna attīstībai nelabvēlīgi apstākḷi, kā arī personām, kuras sasniegušas vecumu, kas dod tiesības saņemt vecuma pensiju (Saeima, 2002a).

Funkcionālais traucējums - slimības, traumas vai iedzimta defekta izraisīts fiziska vai garīga rakstura traucējums, kas ierobežo personas spējas strādāt, aprūpēt sevi un apgrūtina personas iekḷaušanos sabiedrībā (Saeima, 2010a).

Galalietotājs - (end user) - sākotnēji šis jēdziens ir parādījies pagājušā gadsimta 80. gadu beigās datorikā kā multifunkcionālo kopīgā darba produktu galalietotājs. Galalietotājs ir indivīds, kas lieto produktu tad, kad tas ir izveidots un tiek piedāvāts tirgū. ${ }^{2}$ Sociālo pakalpojumu galalietotājs ir sociālo pakalpojumu organizāciju sniegto sociālo pakalpojumu saṇēmējs jeb galalietotājs. Tekstā dažkārt tiek lietota saīsināta jēdziena forma, proti, galalietotājs. Sociālās labklājības jomā Eiropas Savienībā termins "sociālo pakalpojumu galalietotājs" ir aizstājis terminu "sociālā darba klients"

1 Iekavās ir norāde uz avotu, no kura ir pārṇemta termina vai jēdziena definīcija vai skaidrojums. Avota pilnais nosaukums dots raksta par personu ar invaliditāti vajadzībām atsaucēs.

2 Rouse, M. Definition end user. Available: https://whatis.techtarget.com/definition/end-user [accessed: April 14, 2018]. 
kā vienots apzīmējums daudzveidīgo sociālo pakalpojumu saṇēmēju kategorijām. Piemēram, Dānijā sociālās labklājības jomā ir nepiel̦aujami lietot jēdzienu "klients", jo tas sociālo pakalpojumu galalietotājus liek uztvert kā pasìvus objektus, tādēḷ Dānijā tas aizstāts ar universālo jēdzienu "pilsonis" (citizen), tā pievienojot terminam tādu papildu nozīmi, ka katrs varam reizēm kḷùt par sociālo pakalpojumu galalietotāju un tāds būt.

Grupu māja (dzīvoklis) - māja vai atseviškşs dzīvoklis, kurā personai ar garīga rakstura traucējumiem nodrošina mājokli, individuālu atbalstu sociālo problēmu risināšanā un, ja nepieciešams, sociālo aprūpi (Saeima, 2002a).

Iekḷaujoša sabiedrība (inclusive society) - uz universālām cilvēktiesībām balstīta pieeja dažādībai un atškirīibām, kuras pastāv un ir novērojamas sabiedrībā.

Iesaistǐšana un/vai iesaistišanās (involvement) - jēdziens, kas izsaka procesu, norisi, notiekošo saistībā ar vajadzību apzināšanu un darbībām, kas veicina to apmierināšanu. Parasti sākumā sociālo pakalpojumu sniedzēji ir pakalpojumu galalietotāju iesaistītāji vajadzību kopīgā noskaidrošanā, formulēšanā un darbībās, kas tās l̦autu apmierināt un uzlabotu viṇu dzīves situāciju. Sociālo pakalpojumu galalietotāju gaidītā reakcija ir kritiskās domāšanas lietojums un iesaistǐšanās aktīvā rīcībā, lai paši piedalītos sociālo pakalpojumu veidošanas procesā un tā uzlabotu gan savu, gan citu, gan kopienas dzīves kvalitāti.

Projektā ir izmantotas četras sociālo pakalpojumu galalietotāju iesaistǐšanas metodes savu vajadzību izvērtēšanā un apzināšanā. Tās ir, pirmkārt, ātrais līdzdalīgais novērtējums (participatory rapid appraisal). Šì metode ir izmantojama, ja nepieciešams ātri novērtēt situāciju, ņemot vērā galalietotāju zināšanas un viedokluus. Metodes pamatā ir ideja, ka cilvēki ir savas dzīves situācijas eksperti.

Otrkārt, log̣iskās strukturēšanas pieeja (logical framework approach). Tã ir deviṇu soḷu metode. Šie soḷi ir 1) konteksta analīze, 2) iesaistīto/ieinteresēto pušu (stakeholder) analīze, 3) problēmas analīze, 4) mērḳu analīze, 5) aktivitāšu plāna izstrāde, 6) resursu plāna izstrāde, 7) indikatoru noteikšana, 8) risku analīze, 9) pieñēmumu analīze. Vajadzību apzināšanai ir izmantojami pirmie trīs soḷi. 
Treškārt, mugursomas metode (backpack method). Par mugursomas metodi to sauc tādēl, ka pirmais jautājums darbā ar tādu sociālo pakalpojumu galalietotāju kategoriju kā bēgli parasti ir "Kas bija jūsu mugursomā, ko pañēmāt līdzi no mājām?”. Mugursomā var būt gan lietas, gan kaut kas simbolisks vai pat ideja. Mugursoma te drīzāk ir simbols pagātnes, tagadnes un nākotnes vērtībām. Ceturtkārt, nākotnes darbnīca (future workshop), kas ir trīs fāžu metode. Pirmā ir kritiskā fāze (grupas kritiskā domāšana par problēmām tagadnes situācijā), otrā ir fantāzijas fāze (idejas un ieteikumi, kā mainīt situāciju) un trešā ir îstenošanas fãze (rīcības plāna veidošana un konkrēto rīcību apspriešana). Detalizētāk šīs metodes ir izklāstītas šì izdevuma rakstā "Iesaistīšana un iesaistīšanās līdzdalībai pārmaiṇu procesā".

Iesaistītās/ieinteresētās puses (stakeholders) - šis jēdziens apzīmē visus, kas ir redzami vai neredzami, tieši vai netieši ir iesaistīti un/ vai iesaistījušies kaut kādā pasākumā, norisē, lēmumu pieṇemšanā, lai to ietekmētu. Jēdziens tiek latviskots dažādi. Tas tiek tulkots kā 1) iesaistītā puse, 2) ieinteresētā puse, 3) interešu grupas, 4) rīcības grupas, 5) iesaistītais un/vai ieinteresētais aktors (actor), aǵents.

Jēdziens stakeholder var ietvert visu lielo sociālo struktūru valsts, privātās uzṇēmējdarbības un pilsoniskās sabiedrības jeb trešà sektora - pārstāvjus, kas iesaistās rīcībā, lai risinātu problēmas, ietekmētu lēmumu pieņemšanu, vairotu kopīgo labumu un/ vai gūtu kādu labumu sev.

Invaliditāte - ilgstošs vai nepārejošs ḷoti smagas, smagas vai mērenas pakāpes funkcionēšanas ierobežojums, kas ietekmē personas garīgās vai fiziskās spējas, darbspējas, pašaprūpi un iekḷaušanos sabiedrībā (Saeima, 2010a).

Jauktā mācīšanās (blended learning) - sociālās spēcināšanas metode, kurā zināšanu ieguve klātienes mācībās apvienota ar mācǐšanos un komunikāciju tīmeklī.

Konvivialitāte (conviviality) - cilvēku kopdzīves modelis, kas balstīts uz laipnību, saticību, draudzīgumu un savstarpēju uzticēšanos un atbalstu.

Kopīgais sekretariāts (Joint Secretariat) - pārvaldības institūcija Eiropas Savienības Interreg teritoriālās sadarbības programmai 2014.-2020. gadam. 
Lìdzdalības pētîjums (participatory research) - pētījumu metode sociologijāā, kas iekḷauj ar risināmo jautājumu saistītās personas pētījumu metodologijas veidošanas un norises procesā.

Mācišanās rīcībā un mācīšana rīcībā (action learning) - izmantojot šo metodi, personāls, kas sniedz sociālos pakalpojumus, praktiski strādā mazā (5-6) sociālā darba profesionāḷu vai sociālās labklājības studentu grupā, iesaistot sociālo pakalpojumu galalietotājus, lai meklētu labākos konkrētu problēmu risinājumus un uzlabojumus. Iesaistīšanai un iesaistīšanās procesam ir kopīga iezīme ar līdzdalỉbas pètījumu metodi (participatory research) sociolog̣ijā.

Novērotājs (observer) - viena no daudzajām sociālo pakalpojumu organizāciju personāla lomām. Mācīšanā rīcībai un grupu darbā novērotāja uzdevums ir pierakstīt novērojumus un izteikt pārdomas, izbrīnu un/vai šaubas par novēroto, norises laikā neiesaistoties grupas diskusijā.

Pamatvajadzības - ēdiens, apgérbs, mājoklis, veselības aprūpe, obligātā izglìtỉba (Saeima, 2010a).

Persona ar invaliditāti - termins, ar kuru oficiālos un formālos tekstos - sociālās politikas un likumdošanas dokumentos - apzīmē personas ar dažādiem funkcionāliem traucējumiem un ierobežojumiem, piemēram, ar kustību traucējumiem, maṇu orgānu traucējumiem, garīgās attīstības traucējumiem, psihiskiem traucējumiem.

"Persona ar invaliditāti - persona, kurai Invaliditātes likumā paredzētajā kārtībā ir noteikta invaliditāte." (Saeima, 2010a)

Pusceḷa māja - sociālās rehabilitācijas institūcija vai ilgstošas sociālās aprūpes un sociālās rehabilitācijas institūcijas struktūrvienība, kurā personām ar funkcionāliem traucējumiem nodrošina sociālu rehabilitāciju, patstāvīgai dzīvei nepieciešamo pašaprūpes iemaņu un dzīves prasmju apgūšanu vai nostiprināšanu (Saeima, 2002a).

Sociālā spēcināšana (social empowerment) - šì jēdziena saturiskā jēga un būtība saistìta ar varas pārdalī̌sanu sabiedrībā, iedalot vairāk varas sociāli vājām, mazaizsargātām, viegli ievainojamām sociālām grupām. Vairāk varas tiek iegūts, sniedzot un apgūstot zināšanas, attīstot kritisko domāšanu un aktīvi rìkojoties. Sociālo spēcināšanu veic profesionāḷi izglītības, sociālās labklājības, veselības aizsardzības jomā, kā arī pilsoniskās sabiedrības organizācijas un brīvprātīgie, sniedzot reālu materiālu un psiholog̣isku palīdzību 
kritiskās un/vai krīzes situācijās. Sociālās spēcināšanas mērḳis ir panākt, lai vājās sociālās grupas aktīvi rīkojas un tādējādi panāk savas dzīves situācijas uzlabošanos.

Latviešu valodā angḷu valodas termins dažkārt tiek tulkots kā spējināšana, taču šāds tulkojums neizsaka vārda saturisko jēgu un kodolu.

Sociālo pakalpojumu sniedzēji (social service providers) - plašāks jēdziens par sociālā darbinieka (social worker) jēdzienu. Sociālo pakalpojumu sniedzējs - persona, kas sniedz sociālās aprūpes, sociālās rehabilitācijas, profesionālās rehabilitācijas un sociālā darba pakalpojumus (Saeima, 2002a).

Spējinātājs (facilitator) - viena no daudzajām sociālo pakalpojumu organizāciju personāla lomām. Mācībās kā spēcināšanas instrumentā un grupu darbā tā ir skolotāja/instruktora loma. Spējinātāja uzdevums ir palīdzēt kaut ko darīt vieglāk, veicināt problēmu apspriešanu, sniegt padomu, kā rīkoties, kopīgi meklēt risinājuma variantus, vienlaikus izvairoties no autoritatīva rīkojuma, kurā norādīts, kas būtu jādara galalietotājam.

Vajadzību apzināšana (needs assessment) - sociālo pakalpojumu galalietotāju aktuālo pamatvajadzību noskaidrošana, pakalpojumu galalietotājiem aizpildot anketas un tās definējot grupu vai individuālās intervijās.

Vecāka gadagājuma personas (older persons) - šo jēdzienu lieto tāda autoritatīva institūcija kā Apvienoto Nāciju Organizācija Deklarācijā par vecāka gadagājuma personām un Eiropas Savienības oficiālos dokumentos, kas saistīti ar vēlīnā vecuma grupu.

Veicinātājs (enabler) - viena no daudzajām sociālo pakalpojumu organizāciju personāla lomām. Mācīšanās rīcībai un grupu darbā tā ir loma, kuras uzdevums ir padarīt kaut ko par iespējamu vai radìt nepieciešamos nosacījumus, lai saglabātu vēlamo lietu stāvokli vai arī veicinātu vēlamās pārmaiņas. 


\section{levads}

2015. gada 19. novembrī Eiropas Savienības Interreg Baltijas jūras regína teritoriālās sadarbības programmas 2014.-2020. gadam valstu Kopīgais sekretariāts, kas ir tās pārvaldības institūcija, informēja Eiropas teritoriālās sadarbības projekta "Sociālā spēcināšana reğionos" (Social Empowerment in Rural Areas, akronīms SEMPRE) pieteicēju un potenciālo vadošo partneri, ka ir pieņemts lēmums par šì projekta finansēšanu. Tālaika trīs Latvijas partneru - Latvijas Universitātes, Liepājas Diakonijas centra un nevalstiskās organizācijas "Talantu kalve" - kopīgā domu apmain̄ā par projekta nosaukuma latviskojumu izvēle no pieciem piedāvātiem variantiem nosliecās par labu pārliecinoši argumentētajam nosaukumam "Sociālā spēcināšana regionos".

SEMPRE projektā ir iesaistītas visas astoņas Eiropas Savienības Baltijas jūras reǵiona valstis: Dānija, Igaunija, Latvija, Lietuva, Polija, Somija, Vācija un Zviedrija. Projekta partneru skaits ir sešpadsmit, jo dažas dalībvalstis pārstāv vairāki partneri. Tà Igauniju un Somiju katru pārstāv divi partneri, Latviju, Vāciju un Zviedriju katru pārstāv trīs partneri. Projekta partneri no Latvijas ir Latvijas Universitāte, Liepājas Diakonijas centrs, un iecerētās "Talantu kalves" vietā par partneri 2016. gada rudenī kḷuva Vidzemes Augstskola.

Projekta pamatmērḳis ir noskaidrot, kādas pārmaiņas būtu vēlams vai nepieciešams veikt, lai sociālo pakalpojumu organizāciju personāls kḷūtu rīcībspējīgāks un atvērtāks pārmaiņām. Tajā tiek apzināts, kādas jaunas pieejas, metodes un instrumentus nepieciešams ieviest sociālo pakalpojumu organizāciju darbā, ko mainìt vai uzsākt no jauna un kā spēcināt to personālu, lai ikdienas darbs ar sociālo pakalpojumu lietotājiem būtu sekmīgāks. Pārmaiṇas sociālo pakalpojumu organizācijās, spēcinot dienestu personālu, varētu kāpināt to darbinieku rīcībspēju veikt pārmaiṇas sociālo pakalpojumu galalietotāju apziṇā un uzvedībā.

SEMPRE projektam ir izteikti lietišķa, praktiskas cilvēku dzives uzlabošanas ievirze kaut mikroapjomā, ko īsteno mikroprojektos, 
un transnacionālās sadarbības mērḳorientācija. Lietišḳiem pētījumiem, kas tajā veikti, ir praktiska ievirze. Projekta centrālie jēdzieni un idejas ir saistītas ar sociālo spēcināšanu un iesaistī̌̌anu/iesaistǐšanos (involvement) sociālās norisēs, sniedzot un saņemot sociālos pakalpojumus. Latviešu valodā anglu valodas jēdzienu involvement, lai atbilstoši atklātu tā saturu, ir nepieciešams tulkot divējādi - gan kā 'iesaistī̌sana', gan kā 'iesaistīšanās', jo šis jēdziens apzīmē procesu, kurā sociālo pakalpojumu organizāciju personāls iesaista sociālo pakalpojumu galalietotājus sociālo pakalpojumu veidošanā un/vai rīcībā, kas var būtiski mainìt un uzlabot sociālo pakalpojumu galalietotāju dzīves situāciju. Iesaistīties, līdzdarboties vai turpināt būt pasìva sociālo pakalpojumu galalietotāja lomā ir šo cilvēku izvēle.

Interreg programmas principiāla nostādne projektu īstenošanā ir apzināta pētniecỉbas ierobežošana. Tādēḷ SEMPRE projektā mērḳtiecīgi ierobežota izpēte ir veikta, pirmkārt, saistībā ar sociālekonomiskā konteksta kontūru iezīmēšanu lokālo spēcināšanas tîklu vietās. Otrkārt, tika apzināti subjekti, kas ietekmē sociālos procesus. Subjekti, kas ietekmē lietu gaitu, tiek saukti par iesaistītajām/ieinteresētajām pusēm (stakeholders). Šai projektā interesi izraisa tas, kā dažādi subjekti ietekmē lokālo spēcināšanas tỉklu darbỉbu. Treškārt, tiek skaidrots projektam būtisko jēdzienu - sociālā spēcināšana un iesaistišana/ iesaistišanās - saturs un teorētiskā pieeja, kurā tie tiek lietoti projektā, kā arī iesaistīšanas/iesaistīšanās un sociālās spēcināšanas, ko veikuši partneri, labās prakses piemēri. Ceturtkārt, empīriski ticis noskaidrots, ar kādām barjerām un šḳēršlıiem ikdienas darbā nākas sastapties sociālo pakalpojumu sniedzējiem un kādas ir sociālo pakalpojumu galalietotāju vajadzības. Sociālo pakalpojumu galalietotāju aktuālās vajadzības tika apzinātas, iesaistot vinus līdzdalīgā savu vajadzību noskaidrošanā.

Tā kā pētniecība projektā ir apzināti ierobežota, tad arī teoriju pārskats un izklāsts šai grāmatā ir apzināti ierobežots ar ieskatu tajās teorijās par spēcināšanu, iesaistišanu/iesaistǐšanos, iesaistītajām/ ieinteresētajām pusēm un vājo sociālo grupu vajadzībām, kas tikušas pieņemtas par pamatu projekta īstenošanai. Praktiskam lietojumam ir izvēlētas vien dažas teorijas. Par izvēles kritēriju ir izmantots to lietderīgums, lai izveidotu rīcības koordinātu sistēmas un projektu pamatkoncepciju par nepieciešamām pārmaiṇām sociālo pakalpojumu sniegšanas sfērā, sociālo spēcināšanu, sociālo pakalpojumu lietotāju iesaistî̌sanu/iesaistǐšanos savu vajadzību apzināšanā un apmierināšanā 
un lai iespēju robežās kḷūtu par noteicējiem savas dzives pārvaldībā un savas dzīves kvalitātes veidošanā.

SEMPRE projekta savdabība ir tā, ka tiek veikts darbs ar daudzveidīgām sociālo pakalpojumu galalietotāju kategorijām. Projekta partneriem bija iespēja izvēlēties to sociālo pakalpojumu galalietotāju kategoriju, kuru tie vēlētos spēcināt. Dānijas, Somijas, Vācijas un Zviedrijas partneri izvēejēās spēcināt bēgḷus un imigrantus. Igaunijas partneri izvēlējās spēcināt gimenes ar bērniem depresīvā valsts ziemel̦austrumu regionā un no ieslodzījuma atbrīvotās personas. Savukārt Lietuvas partneri - viena vecāka gimenes un tos no alkohola un narkotikām atkarīgos, kas vēlas atbrīvoties no vielatkarībām. Viena vecāka gimenes ir sociālās spēcināšanas objekts arī Vācijas partnerim no Ditmāršenes (Dithmarschen). Latvijas partneru izvēle ir sociāli spēcināt pieaugušās personas ar invaliditāti Kurzemes regionā un tādus jauniešus ar zemu izglîtības un prasmju līmeni, kuri nav iekḷāvušies darba tirgū Vidzemes reǵionā. Ilgstoši bezdarbnieki ir Vācijas partnera izvēle Plēnē. Viens no Somijas partneriem ir izvēlējies spēcināt vecāka gadagājuma personas lauku dzīvesvidē.

Tā kā SEMPRE projekta praktiski orientētā logika ir veidot sociālos pakalpojumus tā, lai tie būtu sociālās spēcināšanas rīki, tad šim nolūkam SEMPRE projekta ietvarā tiek īstenoti mikroprojekti kā praktiskas sociālo pakalpojumu lietotāju spēcināšanas īstenošanas un testēšanas rīks. Mikroprojekti ir sociālo pakalpojumu galalietotāju iesaistîšana/iesaistī̌̌anās praktiskā rīcībā, lai pašu spēkiem uzlabotu savus dzīves apstākḷus, kā arī savas dzīves un vides kvalitāti, ieviestu jauna veida sociālos pakalpojumus, pārveidotu esošos vai izveidotu jaunus sociālos uzṇēmumus. Iesākumā parasti tie ir neliela apjoma pārmainu testēšanas pasākumi. Mikroprojektu īstenošanā sociālo pakalpojumu galalietotāji tiek iesaistīti, viņus informējot un pārliecinot par pārmainu lietderīgumu. Pèc tam galalietotāji brīvprātīgi tajos iesaistās un faktiski tos issteno paši. Sociālo pakalpojumu sniedzēju loma ir būt par mentoriem, rīkojot kopīgas pārrunas, palīdzot piekḷūt resursiem un sniedzot padomus, ja tie tiek lūgti.

Stadijas mikroprojektu īstenošanā, raugoties no sociālo pakalpojumu organizāciju profesionāļu puses, pirmkārt, ir sociālo pakalpojumu galalietotāju vajadzību apzināšana, to formulēšanā iesaistot sociālo pakalpojumu galalietotājus, otrkārt, pārdomas par sociālo pakalpojumu attīstī̌anu un racionalizāciju, domājot par to, kādas pārmaiṇas 
veikt esošos pakalpojumos, kādus radīt no jauna. Treškārt, tā ir līdzdalība pakalpojumu galalietotāju rīcības vadīšanā, sniedzot atbalstu komunikācijā, finanšu piesaistē, konfliktu risināšanā, informējot un psihologiski iedrošinot.

Mikroprojekti ir orientēti uz sociālo grupu un/vai vietējās kopienas spēcināšanu. Sociālo pakalpojumu organizāciju personālam mikroprojekti paver pārmaiņu perspektīvu sociālo pakalpojumu piedāvājumā un pakalpojumu galalietotāju iesaistišanā, lai pārvaldītu savu dzìvi un veidotu to pašu spēkiem.

Ja ieskicē projekta īstenošanai iegūtos datus, tad sociālekonomiskā konteksta rādītāju salīdzināšana Baltijas jūras regiona valstu projekta īstenošanas vietās rāda, ka dominējošās sociālo procesu tendences ar dažiem izṇēmumiem ir līdzīgas. Šīs tendences ir depopulācija jeb iedzīvotāju skaita samazināšanās lauku apdzīvotās vietās, iedzīvotāju sastāva novecošana, tādas dzīves kvalitāti pasliktinošas pārmaiņas infrastruktūrā kā vitāli svarīgu sociālu pakalpojumu pieejamības samazināšanās vai izzušana pavisam. İpaši izteikta sociālo pakalpojumu pieejamības mazināšanās Baltijas valstīs notiek tādās jomās kā veselības aprūpe, izglìtība, pārvietošanās ar sabiedrisko transportu, bankomātu un banku pieejamība, pasta un iepirkšanās vietu pakalpojumu pieejamība. Skandināvijas valstu un Vācijas specifiskā problemātika ir saistīta ar 2015. gadā strauji pieaugošo bēgḷu un imigrantu plūsmas sociālo integrāciju. Te minētie sociālie procesi liek meklēt inovatīvus risinājumus sociālo pakalpojumu sniegšanā.

Grāmatas saturs organizēts tā, lai tajā iekḷautu projektam kopīgo būtisko tematiku un Latvijas Universitātes pētnieku iegūto unikālo izpētes materiālu par pieaugušo personu ar invaliditāti aktualizētām vajadzībām Kurzemes reǵionā. Sākumā ir iztirzāti visiem projekta partneriem kopīgie būtiskie teorētiskie temati un tiem pievienoti labas prakses piemēri kā praktiskie risinājumi. Visiem partneriem kopīgais tematiskais kodols ir iztirzāts rakstos par sociālo spēcināšanu, sociālo pakalpojumu lietotāju iesaistī̌sanu/iesaistī̌̌anos un iesaistītajām/ieinteresētajām pusēm. Šie jēdzieni un koncepcijas izklāstītas, sniedzot ziņas par to izcelsmi un attīstìbu.

Šiem rakstiem seko raksti, kas balstīti uz empīriskās informācijas analīzi. Tie sniedz informāciju par sociālekonomisko kontekstu lokālās spēcināšanas tīklu vietās, barjerām un šḳēešçiem sociālo pakalpojumu organizāciju personāla darbā, iesaistītajām/ieinteresētajām pusēm 
pakalpojumu sniegšanā dažādām sociālo pakalpojumu galalietotāju kategorijām. Noslēdzošais raksts ir par vajadzībām, kuras izjūt pieaugušās personas ar invaliditāti Kurzemes reǵionā.

Personu ar invaliditāti vajadzības ir apzinātas, sadarbojoties Latvijas Universitātes un Liepājas Diakonijas centra projekta partneriem. Materiāls par personu ar invaliditāti vajadzībām ir visapjomīgākais, jo tajā ir iekḷauta sociālās politikas un likumdošanas analīze. Divos pielikumos, kas seko rakstam par personu ar invaliditāti vajadzībām, ir atrodams detalizētāks materiāls par sociālās politikas nostādnēm un likumdošanu saistībā ar sociāliem pakalpojumiem personām ar invaliditāti. Profesionāḷiem, kas specializējušies strādāt ar šo sociālo pakalpojumu galalietotāju kategoriju, tādējādi ir pieejams tiem noderīgs paplašināts informācijas apkopojums.

Katra raksta sākumā ir sniegts tā kopsavilkums angḷu un latviešu valodā.

Lai rakstā būtu vieglāk atrast interesējošo jautājumu, tā sākumā ir nosaukti svarīgākie konkrētā raksta temati.

Par lokālo spēcināšanas tīklu vietu sociālekonomisko kontekstu, kā arī par barjerām un šķērṣ̌liem sociālo pakalpojumu sniedzēju darbā ir atsevišḳi apjomīgi raksti ang̣̦u valodā. Anglu un latviešu valodā ir raksti par iesaistītajām/ieinteresētajām pusēm.

Raksti ang̣̣u valodā ir gatavoti kā informācija projekta partneriem un programmas vadỉbai. Tie ir ievietoti projekta elektroniskajā datubāzē.

Vispārināts projekta ietvaros veiktais darbs - sociālekonomiskā konteksta analīzes rezultāti, apkopojums par barjerām un šḳēršliem sociālo pakalpojumu sniedzēju darbā, informācija par sociālo pakalpojumu sniedzēju mācībām par rīcības veidiem, sociālo pakalpojumu galalietotāju vajadzību apzināšanas dati un pārmaiņu testēšana pilotāžas mikroprojektu formā, visi iegūtie atzinumi, rezultāti un ieteikumi ir apkopoti "Sociālās spēcināšanas rokasgrāmatā", "Organizāciju spēcināšanas ceḷvedī” un "Rekomendācijās politikas veidotājiem". Visi trīs projekta darba rezultātu apkopojumi ir adresēti sociālo pakalpojumu organizāciju profesionāliem un sociālās politikas veidotājiem. Taču arī pakalpojumu galalietotāji var rast vielu pārdomām par savu iespējamo rīcību, iedvesmojoties no labās prakses piemēriem.

Projekts "Sociālā spēcināšana regionos" ir nodrošinājis tā partneriem iespēju mācīties citam no cita, savstarpēji papildināt citam citu, 
apmainīties ar zināšanām par jaunām metodēm un pieejām sociālo problēmu risināšanā. Līdzịgu pieredzi varētu iegūt arī šīs grāmatas lasītāji, it īpaši profesionāļi sociālās labklājības jomā, un interesenti. Projekta rezultātu galvenā nozīmība ir saistīta ar inovatīvu pieeju meklējumiem un atradumiem sociālo problēmu risināšanā. Te atspoguḷotās jaunās pieejas, zināšanas un pieredze var būt noderīgas Latvijā.

Anna Stepčenko

Rīgā un Latvijas Universitātes

Ratnieku lauku teritorijā 2018. gada maijā 


\title{
Anna Stepčenko
}

\section{Sociālā spēcināšana rīcībspējai un pārmaiņām}

\section{Social Empowerment to Capability and Changes}

\begin{abstract}
Summary
The article is dedicated to the study of empowerment concept, its origin and content. At the outset, power and an asymmetric division of power in the society between dominating and subordinated social classes are defined for better comprehension of that concept. The theoretical source for reflection upon empowerment and a way to reach it is advocacy of the subordinated and oppressed social groups by Paolo Freire's humanistic approach.

Further theoretical developments include United Nations' care of individual empowerment and building life conditions to satisfy the basic needs of weak and vulnerable social groups. Empowerment of individuals, groups and communities are combined differently to provide useful means for evaluation.

Social empowerment of the social service provision organizations' staff is in focus of the project SEMPRE and its description in the application form. Staff empowered in trainings with the ideas on innovative approach to problem solving can be better prepared for changes and capable of involving social service end users in shared actions to change their awareness and living conditions. Capability of both service providers and end users has been promoted by action learning and blended learning.
\end{abstract}

Key words: social empowerment of the social service provision organizations' staff and social service end users, change of mindset and actions, raising of innovative capability.

\section{Kopsavilkums}

Šai rakstā tiek iztirzāta jēdziena "sociālā spēcināšana" izcelsme, jēga un attīstība. Sociālās spēcināšanas logika inovatīvā pieejā ir sākotnēja sociālo pakalpojumu sniedzēju spēcināšana, to pārnesot un iedarbinot sociālās spēcināšanas mehānismus sociālo pakalpojumu galalietotāju domāšanā un rīcībā. Projekta 
teorētiskais un praktiskais pamats spēcināšanai ir kritiskās domāšanas prasmju attīstīšana par sociālo realitāti. Kritiskās domāšanas prasmes, kā rāda to pašreizējā aktualizēšana saistỉbā ar informācijas analīzes pratību digitālā vidē, vajadzīgas vienmēr. Sava stāvokḷa apzināšana, sapratne par pastāvošās sociālās iekārtas log̣iku, varas un resursu sadalījumu, savu pozīciju sociālajā hierarhijā un zināšanas, kā ietekmēt varas aǵentus, lai veiktu resursu pārdali, ir Paulu Freires (Paulo Freire) humānistiskās sociālās spēcināšanas pieejas kodols. Apvienoto Nāciju Organizācijas (ANO) iesaistī̌sanās teorētiskā un praktiskā spēcināšanas idejas izstrādē un īstenošanā nozīmē, ka tiek uzsvērta individuālās, grupu un kopienas spēcināšanas kombinēšanas nepieciešamība. Rakstā pievērsta uzmanība spēcināšanas veidiem un metodei "mācīšana/mācǐšanās rīcībā".

Atslēgvārdi: sociālā spēcināšana humānistiskā pieejā, sociālo pakalpojumu sniedzēju un galalietotāju sociālās spēcināšanas metodes, pārmaiṇas domāšanā un rīcībā.

Tematika. Sociālās spēcināšanas jēdziena definīcija un attīstība. Sociālo pakalpojumu galalietotāju spēcināšana rīcībspējai. Sociālo pakalpojumu sniedzēju sociālā spēcināšana. Mācību metodes un modeḷi. Mācīšana/mācīšanās rīcībā (action learning).

\section{Sociālās spēcināšanas jēdziens un tā attīstības logika}

Sociālās spēcināšanas jēga, to skaidrojot īsumā, ir pārdalīt varu un resursus, proti, kaut nedaudz vairāk varas resursu iegūt pašām sociāli vājām, viegli ievainojamām grupām un/vai iedalīt kaut kādus varas resursus arī mazaizsargātām, diskriminētām, marginalizētām sociālām grupām. Ang̣̣u valodā vārds power nozīmē 'vara', empowerment - 'varas pieaugums, palielināšana jeb spēcināšana'. Klasiskus un l’oti spēcīgus apcerējumus par varu un tās lietojumu sabiedrībā ir sarakstījuši Nikolo Makjavelli (Nicolo Machiavelli), Mišels Fuko (Michel Foucault), Eliass Kaneti (Elias Canetti). Vara nozīmē spēku, zināšanas, lēmumu pieņemšanu un pieeju resursiem. Kodolīgo varas formulu, kas ir arī sociālo pakalpojumu sniedzēju un galalietotāju spēcināšanas procesa sastāvdaḷa, formulējis Frānsiss Bēkons (Francis Bacon). Šì formula tradicionāli ir latviskota kā "zināšanas ir spēks", bet to noteikti atbilstoši vārdu jēgai var tulkot kā "zināšanas ir vara" (Knowledge is power), sociālā kontekstā tā ir reāla vara pār tiem, kam zināšanu nav.

Sociālās labklājības jomā klasisku sociālās spēcināšanas skaidrojumu ir devis sociālo zinātṇu un pieaugušo izglitības kritiskās pieejas 
iedibinātājs Paulu Freire. Viņš un Mailss Hortons (Miles Horton) tiek uzskatīti par spēcināšanas sistēmiskās metodologijas un teorijas aizsācējiem 20. gs. otrajā pusē. Spēcināšanas jēdziens ticis lietots arī agrāk, taču tā saturu izprata intuitīivi (Elisheva, 30). 20. gs. pēdējā desmitgadē spēcināšanas teorija tiek strauji attīstìta un to lieto ne tikai dažādu sabiedrībā kritiski vērtētu sociālo grupu spēcināšanai, bet arī organizāciju personāla spēcināšanai

Freires sociālās spēcināšanas koncepcija ir SEMPRE projekta sociālās spēcināšanas idejas izpratnes pamatā. Šo koncepciju savā praktiskā un izglìtošanas darba pieredzē ilgstoši izmanto projekta dalībvalsts - Dānijas - sociālā darba ekspertes un docētājas Dienviddānijas Universitātes sociālā darba specialitātē Anete Nilsena (Anette Nielsen) un Gundi Šretere-Johansena (Gundi Schrötter Johannsen). Abas dān̨u speciālistes projektā ir piedāvājušas apgūt vairākas mācību metodes un reāli spēcinājušas sociālo pakalpojumu sniedzējus mācībās par to, kā rīkoties, lai ieviestu pārmaiņas un mācībām piesaistìtu pakalpojumu galalietotājus.

P. Freire sociālo spēcināšanu ir raksturojis kā procesu, kurā tiek attīstìta, veicināta vai apliecināta kritiskā domāšana un cilvēka intelekta spēks. Freires nolūks bija panākt, ka neprivilegètie indivīdi un neprivilegéēās sociālās grupas, kuru neprivilegétība noteikta pēc to piederības pie rases, etnosa, dzimuma, pie kādas vecumgrupas, invaliditātes statusa, var palielināt savus visdažādāko veidu resursus, spēcinot savu pašapziṇu un kāpinot spēju rīkoties, lai uzlabotu savu psihologisko, sociāli kulturālo, politisko un ekonomisko stāvokli. Cilvēki tam ir jāmāca, un, lai viṇus tam mācītu, cilvēki ir jāmīl. Šai Paulu Freires domai ir pievienojams būtisks papildinājums, ka vienlaikus ir jāmīl arī augstākas vērtības. Šai kontekstā tās ir sociālais taisnīgums un sociālā vienlīdzība, kas, lai arī realitātē nav sasniedzama, tomēr ir noderīga kā tālumā saskatāma bāka, kas palīdz orientēties, uz kādiem idejiskiem pamatiem ir veidojama sociālā dzīve.

\section{Sociālo pakalpojumu galalietotāju spēcināšana}

Lai arī SEMPRE projekta viena no pamatidejām ir sākotnēji spēcināt sociālo pakalpojumu sniedzējus, lai viṇi, būdami atvērti 
pārmaiṇām, rosinātu pakalpojumu galalietotājus veikt pārmaiṇas savā dzìvē, tomēr šai izklāstā sociāās spēcināšanas tematu iesāksim ar pakalpojumu galalietotāju spēcināšanu, bet noslēgsim ar pakalpojumu sniedzēju spēcināšanas veidiem.

Paulu Freires darba "Apspiesto pedagogija" (Pedagogy of the Oppressed, 1968), kam ir zīmola statuss saistībā ar P. Freires personību, pamatideja ir pašreizējo izglitîbas mērḳu atmaskošana un to aizvietošana ar apziņu atbrīvojošās izglìīibas principiem. P. Freires ieskatā pastāvošã izglìtības sistēma faktiski ir vērsta uz savas mazvērtības ieprogrammēšanu zemāko sociālo slāṇu un tradicionāli sabiedrībā kritiski vērtētu grupu (rasu, etnosu, sieviešu, homoseksuālistu, vientuḷo māšu, personu ar invaliditāti) apziņā un ekonomiski labklājīgā sociālā slāṇa, kas vienlaikus ir politiski valdošais slānis, pārākuma atzǐšanu. Pastāvošã izglītỉbas sistēma, lai saglabātu esošo sociālo lietu kārtību, izglītojamos orientē uz trīs mērḳiem, - pirmkārt, uz karjeru un ar to saistìto specializāciju, otrkārt, uz pakḷaušanos autoritātēm, tātad atkarības attiecībām un, treškārt, uz patērniecību - nokḷūšanu neapstādināmā preču un pakalpojumu pirkšanas-pārdošanas ratā, tā griešanās ātrumu sasaistot ar priekšstatu par "labu dzīvi”. Trīs minētie mērḳi atražo pašreizējo varas un ekonomisko resursu sadales stāvokli sabiedrībā un pieradina būt sociāliem konformistiem, kas nozīmē pieņemt šãdu stāvokli un tam piemēroties. Tā tiek veidota apspiesto sabiedrība, un tajā valdošā ir klusēšanas kultūra (culture of silence) (Aubrey, 2004, 8).

P. Freire iestājas par apspiešanas pedagogijas aizstāšanu ar atbrīvojošo pedagog̣iju - kritiskās domāšanas attīstīšanu, kam jāseko uz vienlīdzības principu balstītam atškirīgo sociālo slāņu dialogam. Klusēšanas kultūra ir jāpārtrauc un jāaizstāj ar pretošanās kultūru (culture of resistance). Pārejai jānotiek šādā secīgā procesā: "redzēt/ saskatìt - spriest/domāt - rīkoties" (process of see-judge-act) (Aubrey, 2004, 10), kam jāpievieno rīcības iznākuma pārdomāšana/novērtēšana. Izglìtotājiem, kas grib attīstīt atbrīvotu apziṇu, visam pāri nepieciešama ticība cilvēkiem un to mīlestîba. Apspiestajiem sociālo pakalpojumu lietotājiem (Aubrey, 2004, 12), kuru apziņa izglītības laikā tikusi atbrīvota, savas dzīves apstākḷu uzlabošanas labad ir jāuzsāk aktīvais, nepārtrauktais process, kas sastāv no kritiskās domāšanas, kurai seko rīcība, rīcỉbai seko refleksija par izdarīto un rezultātu, tam seko nākamā rīcība - refleksija. 
Sociālā spēcināšana ir nepārtraukts trīsdaḷīgs process: kritiskā domāšana - rīcība - refleksija. Tas iesākas ar vēlmi radīt pārmaiņas. Pārmaiņu procesa īstenošana var notikt, ja ir zināšanas, prasmes, mācišanās iespēja. Rezultātā ir iegūta atziņa par iespēju rīkoties, lai ieviestu pārmaiņas, tad tās pārdomāt un atkal rīkoties, varbūt labojot kḷūas vai darot vienkārši citādāk, nekā ticis darīts iepriekš.

Paulu Freires humānistiskajai pieejai seko skandināvu sociālās labklājības veidotāji. Šìs pieejas kontekstā ir noteikti pieminama uz humānismu balstītā ANO ilglaicīgā uzmanība sociālās spēcināšanas jautājumam. ANO sagatavotā materiālā par sociālo spēcināšanu ir apkopotas spēcināšanas definīcijas, kuru skaits ir liels, un tās ir dažādas, jo veidotas no atškiringiem skatpunktiem uz šo parādību, bet to kopèjā saturiskā jēga ir balstīta uz ANO Vispārējā cilvēktiesību deklarācijā izteiktām pamatvērtībām. Cilvēka dzīvei vajadzētu būt labai un saskaņotai ar cilvēka cieņu (UNO, 2012). Lai to panāktu, tiem, kas atrodas sociāli spēcīgākā pozīcijā, ir jāiestājas par augstākām vērtībām un to lietojumu lēmumu pieņemšanā sabiedrības pārvaldības struktūrās, lai tādējādi uzlabotu sociāli vājo, mazaizsargāto grupu dzīvi.

ANO stratēégiski sasaista sociālo spēcināšanu ar ilgtspējīgu attīstību (UNO, 2009). Šai apjomīgā dokumentā ir ietvertas zināšanas par ilgtspējīgu attīstību, un tas sastāv no 283 punktiem par procesiem dabā un sociāliem procesiem. Saistībā ar cilvēces ilgtspējīgu attīstību tajā ir iekḷautas visas globālās attīstības problēmas: klimata pārmaiṇas, ekonomika, visu veidu resursi un sociālās attīstības jautājumi, kuru centrā likta izglìtības un veselības aprūpes pieejamība.

Ilgtspējīga attīstība nevar notikt, ja nenotiek sociālā spēcināšana. Tāda ir ANO nostāja. Sociālā spēcināšana ir process, kas iekḷauj virkni pasākumu. Nozīmīgākie pasākumi ir nabadzības mazināšana, izglìīibas un veselības aprūpes pieejamības nodrošināšana, nodarbinātības un piemērota darba iespējas visiem, sociālā integrācija, līdzdalība savas valsts politiskajā dzìvē un lēmumu pien̦emšanā.

"Spēcināšana ir galvenais līdzeklis ilgtspèjīgas attīstības un citu vitālu mērḳu sasniegšanai. Bet tā ir vērtība pati par sevi," tā 2012. gada 5. augustā savu uzrunu starptautiskajā konferencē "Cilvēku spēcināšana un attīstība” Dhakā, Bangladešā, noslēdza tālaika ANO generālsekretārs Bans Kimūns (Ban Ki-moon) (UNO, 2012).

Vēl saistībā ar ANO materiālu par spēcināšanu būtiski ir pieminēt tur iezīmētās divas dimensijas, kas ir vienādi svarīgas cilvēku 
spēcināšanai. Viena dimensija ir tiešã indivīdu un īpaši spēcināmo grupu - bērnu, jaunatnes, sieviešu, vecāka gadagājuma personu, ğimeñu, bēgḷu, nabagu - spēcināšana, attīstot vinu kompetences, spējas, prasmes un zināšanas, lai viņi varētu gūt ienākumus, uzlabot savas ikdienas dzīves kvalitāti un dot ieguldījumu sabiedrības attīstībā. Spēcināšanas rezultātā ir iegūta spēja izvēelēties, tālāk notiek izvēles transformācija rīcỉbā un vēlamā iegūšana vai sasniegšana. Spēcināt var mācības, kā atraisìt un attīstìt savas spējas, kā nodrošināt pieeju finanšu un citiem materiāliem resursiem, kā delegèt varas funkciju, kā būt līdzdalīgiem lēmumu pieņemšanā.

Otra dimensija ir priekšnosacījumu radīšana indivīdu un minēto grupu pamatvajadzību apmierināšanai. Pamatvajadzības ANO piejā spēcināšanai ir miera nodrošināšana, cilvēktiesību ievērošana, pārtikas pieejamība, zemes pieejamība, iespēja iegūt mikrokredītus, izglìtības pieejamíba (UNO, 2012).

Kā pēdējo lai pieminam vēl vienu ANO spēcināšanas definīciju. To ir sniegusi ANO Bēg̣̣u lietu komisija. Tã ir šāda: "Spēcināšana ir process, kurā neveiksmīgā stāvoklī/pozīcijā esošas sievietes un vīrieši palielina savu pieeju zināšanām, resursiem un lēmumu pieņemšanas varai, kāpina apzināšanos par iesaistī̌šnos savas kopienas ikdienas dzīvē, lai iegūtu kontroli pār vidi, kurā dzìvo." (A Practical Guide to Empowerment, 2001, 3) Interesanti, ka Bēglu lietu komisija tūdal pēc šis spēcināšanas definīcijas raksturo, kas ir pretējais process. Kā notiek cilvēku vājināšana (disempowerment)? Vājināšana ir process, rīcība vai programma, kas ignorē cilvēku vajadzības, intereses, mazina vinu līdzdalību lēmumu pieṇemšanā, liek šḳērš̌lus viṇu ekonomiskās, sociālās un politiskās dzīves uzlabošanai (A Practical Guide to Empowerment, 2001, 3).

\section{Sociālo pakalpojumu organizāciju personāla loma pakalpojumu lietotāju spēcināšanā}

Sociālo pakalpojumu organizāciju personāls ir profesionāḷi, kuru viena no daudzajām lomām, kuras tie izpilda, ir būt par sociālo pārmaiņu veicinātāju. Indivīdu, sociālo grupu un/vai kopienas spēcināšana var tikt saprasta un lietota kā pārmainu instruments. 
Sociālo pakalpojumu organizāciju personāla profesionālais uzdevums ir vadīt un mazināt risku sociālos un psihologiskos faktorus. Tas nozīmē: lai veicinātu pārmaiṇas, ir jāietekmē sociālās dzìves vides apstākḷi, lēmumu pieņemšana politikā un indivìdu apziṇa.

Uzskati par sociālo pakalpojumu personāla darba nozīmi un pakalpojumu galalietotāju izturēšanos būtiski atšḳiras sociālo pakalpojumu lietotāju spēcināšanas modernajā un tradicionālajā pieejā.

Tradicionālajā pieejā sociālo pakalpojumu galalietotājs tiek saukts par klientu, uzlūkots kā indivīds, kas ir pasìvs, relatīvi bezpalīdzīgs un kam trūkst zināšanu, spēju, prasmju un pieredzes, kā mainīt savu dzīves situāciju.

Spēcināšanas pieejā sociālo pakalpojumu galalietotājs tiek saukts par pilsoni, lokālās kopienas pārstāvi, kas ir aktīvs indivīds - gimenes, lokālās kopienas un valsts pārstāvis. Viņš vislabāk zina savas dzīves apstākḷus un to nosacỉjumus. Viṇš ir eksperts šajās zināšanās.

Sociālo pakalpojumu galalietotāju spēcināšanas process var noritēt trīs dimensijās - individuālā, sociālo grupu un lokālas kopienas līmenī, tām dažādi kombinējoties. Sociālo pakalpojumu organizāciju personāla galvenais uzdevums pakalpojumu lietotāju spēcināšanā ir būt par pārmaiṇu rosinātāju un spējinātāju.

Individuālā līmenī sociālo pakalpojumu galalietotājiem uzsākt savas dzives spēcināšanas pārmaiņas mudina sociālo pakalpojumu organizāciju personāls, kas motivē pakalpojumu lietotājus uzṇemties atbildību par savu dzīvi, palīdz definēt problēmas un rosina vēlmi tās risināt pašiem, mudina pielikt pūles, lai attīstìtu sevi, apgūtu zināšanas un prasmes, lai spēcinātu sevi. Sociālo pakalpojumu organizāciju personāls šai procesā ir vienmēr pieejamais konsultants.

"Individuālā spēcināšana ir personiskās attīstības process sociālā ietvarā: pāreja no bezspēcības izjūtas un šīs izjūtas radītās dzīvošanas ēnā uz aktīvu dzīvi un reālu spēju rīkoties, uzṇemties iniciatīvu vides un nākotnes veidošanā." (Elisheva, April 8, 133)

Individuālā līmenī spēcināšana vispirms nozīmē indivīda psihologisko spēcināšanu - celt pašcieņas limmeni un pamodināt motivāciju sākt pašam rīkoties un iesaistīties grupu aktivitātēs (Schrötter Johannsen, 2018). Sociālo pakalpojumu lietotājs spēcināšanas procesā jāmotivē iegūt varu pār savu dzìvi, sākt lemt pašam par to, kas viṇa dzìvei vajadzīgs, un rīkoties, lai mērḳi sasniegtu. 
Grupu lìmenī sociālo pakalpojumu profesionāḷu uzdevums spēcināšanā ir veicināt tādu apstākḷu radīšanu, kas ḷautu notikt vēlamajām pārmaiñām. Tas nozīmē diskusijās modināt grupas solidaritātes jūtas, attīstìt vēlmi savstarpēji palīdzēt, būt gataviem kolektīvai rīcībai. Tas varētu būt arī grupu darbs, kur cilvēki, kam ir līdzīgas problēmas, tiktu pulcināti reālā vai virtuāā vidē, lai savstarpēji spēcinātu cits citu. Projekta partneru vidē Ditmāršenē, Vācijā, ir izveidota viena vecāka ğimeṇu virtuālā grupa. Sociālo pakalpojumu profesionālis ir novērotājs un konsultants. Viņam ir vajadzīgās zināšanas un prasmes, kā vadīt grupas dinamiku un ietekmēt attiecības grupā, kā stiprināt sociālā atbalsta tìklus, risināt konfliktus grupā. Projekta darba grupas sesijā nācās piedalìties diskusijā par konflikta risināšanu pieminētajā Ditmāršenes viena vecāka ǵimeņu virtuālā grupā, kur savstarpējā spēcināšana tika nobīdīta malā, kad grupai pievienojās ambicioza, egoistiska māte, kas uzsāka cinnu par līderes lomu grupā, atņemot to līderim.

Lokālās kopienas spēcināšanu ieskicēsim ar divu autoru idejām par to, kas ir kopiena un kā norit kopienas spēcināšana.

"Kopienas spēcināšana balstās uz šādu kopienas definīciju - kopiena ir atsevišks,s, dinamisks, kādu laiku pastāvošs kopums, kuru radījusi cilvēciskā vajadzība pēc kopības izjūtas un identifikācijas ar citiem." (Elisheva, May 4, 133)

Lokālās kopienas līmenī spēcināšana izpaužas, iesaistoties publiskā domu apmaiṇā un notikumu ietekmēšanā, ievērojot savstarpējo cieņu un pieprasot vēlamos rezultātus, arī nevienlīdzības mazināšanu un sociālā taisnīguma pieaugumu (Schrötter Johannsen, 2018). Vietējā kopiena ir stiprināma, kāpinot tās pārstāvju aktivitāti savas dzīves apstākḷu pārmaiṇās, stiprinot sociālo tîklojumu un palielinot pieeju resursiem.

Indivīdu, grupu un vietējās kopienas spēcināšana var kombinēties un saplūst vienotā visu triju vienību un sastāvdalı spēcināšanā. Norbotenas lēne Zviedrijas ziemel̦os rāda labu piemēru vienotai visu triju vienību un sabiedrības sastāvdalıu inovatīvai spēcināšanai. Zviedru projekta partneri Norbotenas lēnē spēcina tur iebraukušos imigrantus no attīstības valstīm. Šai skarba klimata regionā ir izteikts medicīnas un sociālā darba personāla trūkums. Te nometinātos imigrantus māca būt par palīgpersonālu veselības aprūpē un par vecāka gadagājuma cilvēku aprūpētājiem. Ar šādām zināšanām un prasmēm viṇiem tiek dota iespēja iekḷauties darba tirgū. Cits veids, kā imigranti tiek integrēti vietējā sabiedrībā, ir dažādi mikroprojekti, tai skaitā SEMPRE 
projekta ietvaros, kurā tiek sniegtas zināšanas un praktisks atbalsts, kā sākt sociālo uzṇēmējdarbību. Galvenās jomas, kur imigranti uzsāk sociālo uzñēmējdarbību, ir èdināšana un valodu mācības. Jau ilgstoši lielākajā pilsētā Zviedrijas ziemeḷos - Lūleo (Luleå) - sekmīgi darbojas kafejnīca, kas ir imigrantu un vietējo iedzīvotāju kopuzṇēmums. Cita joma, kur imigranti veido sociālās uzņēmējdarbības nišu, ir šǔšanas darbnīcas un imigrantu dzimto valodu mācìbu kursi.

Projekta partneri Somijas Pohjanmā (somu val. Pohjanmaa) regionā bēgḷu spēcināšanai par vienu no vairākiem instrumentiem lieto inovatīvu pieeju, kas ir iedrošinājums un padomdevējs, kā iesakņoties jaunajā mìtnes zemē, izmantojot videofilmu par veiksmīgu afgāṇu gímenes integrāciju Somijas lauku regionā. Padomus, pamatojoties uz savas dzīves pieredzi Somijā, sniedz tēvs. Viṇš strādā celtniecībā un stāsta, ka darbs ir grūts, bet tas ir pamats stabilitātei un vēlmei dzīvot savā mājā, kas reǵionos ir stipri lētāka nekā Helsinkos. Māte mācās frizieres amatu un aprūpē divus bērnus, kas apmeklē somu bērnudārzu. Mājas interjers, kurā dzīvo šì ğimene, viss ir baltā krāsā vai viegli tonēts. Mājās visa gimene ir tērpusies baltās drānās.

Somu partneri liecina, ka tieši pašu bēgḷu un imigrantu informācija par savu dzivi svešā zemē un stāsts par savu pieredzi, kā te veiksmīgāk iekārtoties, nesalīdzināmi spēcīgāk iedarbojas uz imigrantu prātiem nekā svešo somu stāstītais un ieteiktais.

\section{Sociālo pakalpojumu organizāciju personāla spēcināšana}

Spēcināšana šai projektā ir attiecināta uz divu spēlētāju (actors) grupām. Viena grupa ir sociālo pakalpojumu galalietotāji. Otra grupa sociālo pakalpojumu organizāciju personāls jeb sociālo pakalpojumu sniedzēji (SPS). Turklāt galvenā spēcināšanas darba mērksgrupa ir sociālo pakalpojumu sniedzēji.

Organizāciju psihologijāa pie profesijām, kas visvairāk ir pakḷautas psihologiiskai izdegšanai, pieskaita profesijas, kurās notiek saskarsme ar cilvēkiem. Šai sakarā īpaši riskants ir sociālais darbs un pedagogiija. Lìdzīgam izdegšanas riskam ir pakḷautas tās profesiju grupas, kurās ir augsta riska darbs. Tāds, piemēram, ir pilota darbs. 
Sociāāās sfēras profesionāḷ psihologisko izdegšanu veicina daudzu faktoru kopums. Viens no faktoriem ir saistits ar pakalpojumu galalietotāju psihologiisko un ekonomisko stāvokli, dzives apstākḷiem, uzvedību un risināmo situāciju sarežg̀itību. Cita faktoru grupa ir saistīta ar profesionāḷu darba vides apstākḷiem un šì darba novērtējumu algas izteiksmē, tātad ar telpām, kādās viṇi strādā, darbavietu aprīkojumu un atalgojuma līmeni. Apziṇa un izjūta, ka sasprindzinātais darbs netiek pienācīgi atalgots, spēcīgi iedarbojas uz personāla pašapzinuu. Zems atalgojums par smagu darbu rada nomāktības un netaisnības izjūtu, mazina darba sparu, var vedināt un bieži vedina uz domu par darbavietas mainī̌sanu.

Cita nozīmīga faktoru grupa, kas ietekmē darba vides kvalitāti un apmierinātību ar darbu, ir saistīta ar darba organizācijas kvalitāti horizontālās un vertikālās komunikācijas operativitāti, informācijas aprites ātrumu un darbu koordināciju gan organizāciju iekšienē, gan starp institūcijām. Sociālo pakalpojumu profesionāļu aptauja projekta ietvaros uzrāda šo faktoru kopumu, kas saistīts ar neapmierinošu vertikālo un horizontālo komunikāciju, neoperatīvu, novēlotu apmaiņu ar jaunāko informāciju, kā arī ar nepietiekamu darba un funkciju koordināciju starp sociālo pakalpojumu institūcijām.

Sociālo pakalpojumu organizāciju vadītājiem un politikas veidotājiem vajadzētu atcerēties sociālo taisnīgumu un apzināties, ka labi veikt profesionālo darbu var tāds darbinieks, kas ir apmierināts ar darba nosacijumiem.

Personāla menedžments ir sācis pievērst uzmanību darbinieku apmierinātības rādītājiem. Lai noturētu darbiniekus un uzturētu augstu darba ražīgumu, tiek ieviestas dažādas inovācijas. Sociālo pakalpojumu profesionāḷi tiek pasargāti no izdegšanas riska, ja ir saīsināts darbalaiks, tiek mainīts darba veids darbdienas un nedẹlas laikā, notiek supervīzijas pasākumi, korporatīvie pasākumi, tiek izrādīti daudzējādi uzmanības apliecinājumi un laipnība.

\section{Mācības kā spēcināšanas līdzeklis}

Svarīgs sociālo pakalpojumu sniedzēju spēcināšanas līdzeklis ir regulāru mācību rīkošana. SEMPRE projektā tam atvēlēta svarīga vieta. Mācību bloku projektā ir vadījuši Dienviddānijas Universitātes 
mācībspēki, gan gatavojot metodiskus un teorētiska izklāsta materiālus, gan vadot darba seminārus projekta dalïbniekiem kā zināšanu tālāknesējiem, gan organizējot mācības rīcībā un pilotprojektu novērtēšanas semināru.

Pārmaiņas sociālo pakalpojumu personāla uzvedībā tiek uzskatītas par vienu no personāla mācību dizaina mērḳiem (Nielsen, 2018). Mācību mērksauditorija ir pašlaik strādājošie pakalpojumu sniedzēji un sociālās labklājības studenti. Vēlamās pārmaiņas pakalpojumu sniedzēju uzvedībā ir orientētas uz tādu kompetenču apgūšanu, kas atraisītu spējas iesaistīt pakalpojumu sniegšanas procesā pakalpojumu galalietotājus. Spēcināšanas mācību modulis ir iekḷaujams kvalifikācijas celšanas mācībās, studentu mācīšanā un sociālo pakalpojumu organizācijās (in-house training), kur mācību metodēm un saturam jāiekḷauj materiāls par konkrētās pakalpojumu galalietotāju kategorijas reālo dzīves situāciju, un šajās mācībās ir iesaistāmi arī galalietotāji. Kopumā mācības tiek orientētas uz to, lai vislielākie ieguvēji būtu tieši pakalpojumu galalietotāji un lai tiktu veikta reāla, praktiska spēcināšana.

Tiek piedāvāta arī iespēja īstenot jauktas sociālo pakalpojumu sniedzēju mācības (blended learning), kurās tiek kombinētas klātienes mācības un mācišanās tīmeklī.

SEMPRE projekta ietvaros sociālo pakalpojumu organizāciju personāla mācību programma ir sagatavota 2017. gadā. 2018. gada pirmajā pusē ir veiktas pilotmācības partnerības valstu lokālos spēcināšanas tỉklos sociālās labklājības profesionāliem un dažādām pakalpojumu galalietotāju kategorijām.

Anete Nilsena (Anette Nielsen) materiālā par pieaugušo mācībām sociālās labklājības sfērā ir izklāstijusi dažādu autoru pedagoğiskās pieejas mācību procesa ìstenošanā. Par praktiski vispiemērotāko un rezultatīiāko mācību metodi, lai panāktu pārmaiņas pakalpojumu sniedzēju un galalietotāju domāšanā un rīcībā, tiek atzìta mācišana rīcībā un mācīšanās rīcībā. Šo mācību ilgums ir 8-10 nedēḷas.

Mācỉbu procesā ir trīs posmi. Pirmais ir sagatavošanās posms; tiek lēsts, ka tajā tiek ieguldīts 40\% mācību procesa darba. Šajā posmā tiek noskaidrotas vajadzības, formulēti mērḳi, domāts par motivāciju. Otrais posms ir saistīts ar mācībām - to plānošanu, uzdevumiem, materiālu sagatavošanu, instruktāžu un nodarbībām. Tiek uzskatìts, ka tajā tiek ieguldīts 20\% mācību procesa darba. Trešajā posmā notiek aktivitātes pēc mācībām. Šai posmā tiek apspriestas pārdomas par 
mācību rezultātiem, organizatoriskiem šķērš̌liem, atgriezeniskās saiknes efektiem. Tiek lēsts, ka tajā tiek ieguldīts $40 \%$ mācību procesa darba.

Šo mācību gaitā var rīkot dalībnieku seminārus. Pirmo semināru lietderīgi rīkot, uzsākot mācības, otro semināru - mācību vidusposmā, trešo semināru - mācību noslēgumā.

\section{Mācības kā spēcināšanas metode: mācīšana rīcībā un mācīšanās rīcībā (action learning)}

Mācības ir līdzeklis, kas stimulē gan indivīda, gan organizācijas attīstību un transformāciju. Sociālo pakalpojumu kontekstā mācību programmas tiek veidotas tā, lai tās būtu saistītas gan ar problēmu risināšanu, gan arī ar pakalpojumu sniedzēju un galalietotāju spēcināšanu, lai veiksmīgāk atrisinātu problēmu. Šì ir pieaugušo neformālā izglìtība, kas ilgst apmēram divus mēnešus. Tā var tikt organizēta sociālo pakalpojumu organizācijās, kur mācībās var iesaistìt sociālo pakalpojumu galalietotājus. Tā var tikt iekḷauta izglītỉbas iestādēs sociālās labklājības mācību programmās kā atseviškss studiju kurss. Ir jāṇem vērā fakts: tā kā sociālo pakalpojumu galalietotāju kategorijas ir atškirīgas, tad mācību programmas ir veidojamas atbilstoši konkrētās sociālās grupas dzīves situācijas īpatnībām. Šìs mācību programmas mērḳis ir "mainīt uzvedību un veidot tādas ievirzes praksi, kas balstīta uz sociālā darba normām" (Nielsen, 2017, 7). Mācību programmu var veidot tā, lai tajā varētu iesaistīt organizāciju dažādo hierarhisko līmeṇu pārstāvjus. Mācībās ir ieteicams apvienot mācību vielas izklāstu ar dalībnieku dalī̌̌anos personiskā pieredzē, un tajās ir veicināma un piekopjama savstarpējā atbalsta kultūra. Šajās mācībās ir iespējams lietot daudzējādas pedagogiskās teorijas. Pazīstamākās ir balstītas uz jēdzieniem "uzlabošanas jeb kultivēšanas process", "mācī̌nanās cikls", "didaktiskais modelis", "kopienas prakse", "situatīvā mācī̌anās" vai saistītas ar tiem (Nielsen, 2017, 7).

Ieteicamākās un biežāk izmantotās mācǐšanās metodes ir mācī̌anās rīcībā un jauktā mācǐšanās.

Mācīšanās rīcībā noris starp praktisku darbu un mācǐšanos no praktiskā darba, jeb tā ir mācišanās reālā darba praksē. Mācǐšanos 
rīcībā var grafiski attēlot kā spirāli, kuru veido piecas secīgas sastāvdạlas, kas var atkārtoties daudzas reizes. Šìs secīgās sastāvdaḷas ir 1) aizdomāšanās par problēmu (problem wondering), 2) rīcība, 3) novērošana (profesionālis novēro un pieraksta notiekošo), 4) pārdomas, 5) mācīšanās, proti, saprašana, ko esi uzzinājis (Nielsen, 2017, 15). Problēmas konstatēšanai un tās risinājumu meklējumiem seko darītāju apzināšana, darbu plānošana un pati rīcība. Rīcību pienākas vērot, dokumentēt, un var veikt regulāras darba piezīmes. Pēc tam darītāji un novērotāji tiekas. Pārdomu posmā katrs dalībnieks analizē, kāda bijusi rīcība, ko ir gribēts sasniegt un kādas atziņas ir gūtas no šìs rīcības. Piektajā posmā tie, kas ir kopīgi risinājuši problēmu, formulē, ko viṇi ir iemācījušies par metodēm, lomām, jēdzieniem, attiecībām, ko viṇi ir uzzinājuši par tiem, ar kuriem kopā strādāts, par organizācijas struktūru, procedūrām, kooperāciju un kas no uzzinātā turpmāk ir ieviešams praksē.

Mācišanās rīcībā ir uz problēmām orientēta izglītošana un izglītošanās, kas ir izaugusi no reālas problēmas un praktiskas vajadzības to risināt. Tā ir Paulu Freires t. s. atbrīvojošā pedagogiija, kas ir îstenota praksē. Sociālās problēmas subjekti tiek spēcināti, vinuus iesaistot dialogā, rosinot kritisko domāšanu, viniem rodas spēks nosaukt lietas ìstajos vārdos un spēks rīkoties, lai notiktu vēlamās pārmainas. Tà cilvēki paši spēj sevi atbrīvot no apspiestîbas (Nielsen, 2017, 16).

Skolotāja/instruktora loma mācībās rīcībā mainās. Šĩ loma sazarojas un var pārtapt par konsultanta, veicinātāja, gida, atbalstītāja, zināšanu un informācijas pārnesēja lomu. Skolotājs/instruktors kḹūst par gudras rīcības sava veida treneri.

Mācišana rīcỉbā un mācīšanās rīcỉbā var tikt īstenota jauktā veidā, mācišanos organizējot pa daḷai klātienē, pa daļai virtuāā vidē (blended learning). Reālās mācības klātienē un virtuālās mācības var tikt kombinētas un īstenotas mainīgās proporcijās. Šai gadījumā ir veicami papildu organizatoriski pasākumi un ir gatavojami papildu mācību materiāli, kas ir piemēroti virtuālai videi. Īpašs papildu organizatoriskais darbs šai gadijjumā ir veicams, komplektējot izglītojamo grupu - gan pakalpojumu sniedzējus, gan pakalpojumu galalietotājus. Lai mācības virtuālā vidē veiktos sekmīgi, izglītojamie ir jāinstruē, kā veikt darbības, izskaidrojot, kas un kā ir darāms. Papildu darbs šajā mācību formā ir saistīts arī ar atgriezeniskās saites nodrošināšanu. 


\section{Secinājumi}

Sociālā spēcināšana ir process, kura rezultātā rodas pārmaiṇas domāšanā, attieksmēs un rīcībā. Tas rosina iesaistìties citā, jaunā rīcībā, lai turpinātu pārmaiṇu procesu savas profesionālās un individuālās, kā arī sociālās dzìves pilnveidošanā.

Sociālā spēcināšana ir attiecināma gan uz sociālo pakalpojumu organizāciju personālu, kas ir sociālo pakalpojumu sniedzēji, gan uz sociālo pakalpojumu galalietotājiem.

Sociālā spēcināšana ir tehnologija sociālā darba profesijā, kas pastarpināti veido aktīvus, par savu dzīvi atbildīgus pilsoṇus, viņiem sniedzot zināšanas un citus resursus, lai palielinātu sociāli vājo, mazaizsargāto grupu varas potenciālu un rīcībspēju.

Izglītība, kas attīsta kritisko domāšanu un kāpina pašcieṇu un pašvērtības apziņu bērniem, it īpaši bērniem no sociāli zemākiem slāniem, skolās, kā arī mācību programmās pieaugušiem, ir spēcīgs, ja ne visspēcīgākais sociālās spēcināšanas līdzeklis. Šì atbrīvojošās pedagogijias ideja sociāli stratificētā, nevienlīdzīgā sabiedrībā nekad nav zaudējusi savu aktualitāti.

Praksē ir pierādījies, ka mācību metode, saukta par mācīšanu rīcībā un mācīšanos rīcībā (action learning), ir vispiemērotākā un efektīvākā sociālo pakalpojumu jomā. Tajā kopīgi kādu dzìves jautājumu inovatīvi risina sociālo pakalpojumu sniedzēji un galalietotāji. Tādējādi kopīgā rīcībā, kur reālie aktīvie darītāji ir sociālo pakalpojumu galalietotāji, tiek panāktas pārmaiṇas viṇu dzìves situācijā un domāšanā.

Sociālā spēcināšana vispirms ir attiecināma uz sociālo pakalpojumu organizāciju personālu, tā rosina viṇu būt atvērtam pārmaiņām un radīt pārmaiņas pakalpojumu galalietotāju domāšanā, attieksmēs un rīcībā.

Pārmaiņu vektors ir vēršams divos virzienos. Viens no tiem ir indivīda domāšana, attieksmes, konservatīvu ideju komplekss un rīcība, uzvedība. Otrs pārmaiņu vektors ir pārmaiņas sociālās dzīves pārvaldỉbā - nodokḷu politika un sociālā politika, kas orientētos uz sociālo taisnīgumu.

Tā indivīdu dzīves projekts tiek sasaistīts ar sociālo problēmu risināšanu sabiedrībā.

Sociālās labklājỉbas organizāciju pārvaldības līmenī to vadītājiem un sociālās politikas veidotājiem ir nepieciešams apzināties, ka tikai 
tāds darbinieks, kas ir apmierināts ar darba apstākḷiem, komunikācijas kvalitāti visos līmeņos, informācijas aprites operativitāti, darbu koordināciju un atalgojuma līmeni, ir motivēts veikt profesionālo darbu labi un var tikt pasargāts no psihologiskās izdegšanas darbavietā.

\section{Atsauces}

A Practical Guide to Empowerment (2001) Geneva: UNHCR, p. 3 Available: www.refworld.org [accessed: June 10, 2018].

Aubrey, J. The Roots and Process of Social Action. Groupwork. Vol. 14(2), 2004, pp. 6-23. Available: citeseerx.ist.psu.edu/viewdoc/download?doi= 10.1.1.863.8445... [accessed: April 8, 2018].

Elisheva, S. Empowerment and Community Planning. Part 1. Developing a Theory of Empowerment. Available: www.mpow.org/elisheva_sadan_empowerment_part1_intro.pdf [accessed: April 8, 2018].

Elisheva, S. Empowerment and Community Planning. [b.g.] 350 p. Available: http://www.mpow.org/elisheva_sadan_empowerment.pdf [accessed: May 4, 2018].

Nielsen, A. (2018) Action Learning. Handouts at Workshop in Esbjerg. Esbjerg. Nielsen, A. (2018) Designing Training Courses. Handouts at Workshop in Esbjerg, February 26.

Nielsen, A. (2017) Training Courses - an Introduction. Esbjerg, 17 p.

Schrötter Johannsen, G. (2018) Empowerment. The Power to Name - the Power to Act. Handouts in Esbjerg Workshop, February 26.

United Nations Organization. Empowerment: What Does it Mean for You? (2012) Available: http://www.un.org/esa/socdev/ngo/outreachmaterials/empowerment-booklet.pdf [accessed: June 10, 2018].

United Nations Organization. Future We Want - Outcome Document (2009) Available: https://sustainabledevelopment.un.org/futurewewant.html [accessed: June 10, 2018]. 

Anna Stepčenko, Laura Jaunromāne

\title{
lesaistī̌̌ana un iesaistīšanās līdzdalībai pārmaiņu procesā
}

\author{
Involvement of the Social Service Providers \\ and End Users in Process of Change
}

\begin{abstract}
Summary
Social involvement is a path to empowerment aimed at promoting capability of the end users of the social services to engage in changing their own living conditions. The project SEMPRE applied involvement since its very beginning - needs assessment at the outset as the first step to proceed toward practical action.

The article describes the methods of social service end users' involvement in their needs assessment in SEMPRE. These methods include participatory rapid appraisal, backpack method, future workshop, and logical framework approach.

Seven examples are provided to show the best practice of involving social service end users and the positive results attained through that involvement. The article also contains information on start of microprojects in five localities of Kurzeme region, Latvia - five microprojects dedicated to persons with disabilities realized by the representatives of this target group themselves in Grobina, Bārta, Rucava, Durbe un Dubeņi rural municipalities.
\end{abstract}

A supplementary information received in June 2018 by project partners on implementation of 12 microprojects is also included.

Finally, the article describes the actual involvement in food supply programme "Your own contribution to your family table" ("Pats savam saimes galdam") for poor and low-income people in rural areas of Latvia.

Key words: involvement methods of social service end users in needs assessment and service provision, best praxis examples of involvement, actual involvement praxis - microprojects in Kurzeme region of Latvia and partner countries. 


\section{Kopsavilkums}

Sociālo pakalpojumu galalietotāju iesaistǐšanas un iesaistǐšanās process ir līdzdalības pirmelements un iesākums spēcināšanai, lai šos cilvēkus motivētu uzṇemties atbildību būt aktīviem savas dzīves veidotājiem. Iesaistǐšanas/iesaistīšanās efektivitāte SEMPRE projektā tiek pārbaudīta mikroprojektos, kas tiek īstenoti kopprojekta ietvaros. Iesaistǐšana/iesaistǐšanās tiek aizsākta ar vajadzību apzināšanu. Rakstā ir sniegta informācija par četrām metodēm, kas iesaista galalietotājus un kas izmantotas vajadzību apzināšanā. Tās ir: 1) ātrais līdzdalīgais novērtējums (participatory rapid appraisal), 2) mugursomas metode (backpack method), 3) nākotnes darbnīca (future workshop) un 4) logiskās strukturēšanas pieejas metode (logical framework approach).

To, kā var notikt iesaistǐšana/iesaistī̌sanās sociālo pakalpojumu galalietotāju praktiskā savas dzīves apstākḷu uzlabošanā, ilustrē septiṇu îstenotu labas prakses piemēru apraksti.

Ieskatu par praktisko sociālo pakalpojumu lietotāju iesaistīšanas/iesaistīšanās norisi Latvijā sniedz to mikroprojektu apraksti, kas tiek īstenoti Kurzemes reǵiona piecās apdzīvotās vietās: Grobiṇā, Bārtā, Rucavā, Durbē un Dubeņos. Kurzemē mikroprojektu īstenošanā savas dzives kvalitātes uzlabošanā ir iesaistītas personas ar invaliditāti. Iesaistǐšanas/iesaistī̌anās praksi papildina 12 mikroprojektu apraksti, kas 2018. gada jūnijā saņemti no projekta partneriem.

Noslēgumā ir sniegta informācija par 2018. gada sākumā izteikto piedāvājumu trūcīgiem sociālo pakalpojumu galalietotājiem Latvijā iesaistīties programmā "Pats savam saimes galdam", lai atvieglotu savus dzīves apstākḷus, sagādājot sev daļu pārtikas un to izaudzējot pašiem.

Atslēgvārdi: sociālo pakalpojumu galalietotāju iesaistīšanas metodes vajadzību apzināšanā, mikroprojekti kā iesaistīšanas/iesaistīšanās labās prakses piemēri vajadzību apmierināšanā un dzīves kvalitātes uzlabošanā.

Tematika. Sociālo pakalpojumu galalietotāju iesaistīšana savu vajadzību apzināšanā. Četras līdzdalīgās metodes savu vajadzību apzināšanā. Septiṇi labas prakses piemēri. Mikroprojekti Kurzemes reǵionā. 12 mikroprojekti, kurus īstenojuši SEMPRE projekta partneri citās valstīs. Borisa un Ināras Teterovu fonda piedāvājums Latvijas trūcīgām un maznodrošinātām gimenēm iesaistīties pārtikas sagādē, lai uzlabotu savu dzīves kvalitāti. Ieteicamās papildliteratūras un avotu saraksts.

Sociālo pakalpojumu galalietotāju sociālā iesaistǐšana un iesaistīšanās ir norise, kas neškirami, nenodalāmi un organiski saistīta ar spēcināšanas procesu. Šai procesuālajā norisē ir spēcināmi un tiek spēcināti gan sociālo pakalpojumu organizāciju personāls, gan sociālo pakalpojumu lietotāji. 
Sociālo pakalpojumu galalietotāju iesaistīšana tiek uzskatīta par nepieciešamu visa procesa gaitā, sākot ar iesaistǐ̌̌nu un iesaistišanos savu vajadzību apzināšanā un to formulēšanu vārdos un beidzot ar procesa noslēdzošo posmu - rīcību, lai līdzdarbotos savu vajadzību apmierināšanai. Šì pieeja sociālo pakalpojumu galalietotājus uzlūko par savas dzīves ekspertiem, kas pārzina savas vajadzības un, dažādos veidos spēcināti, piedalās savu vajadzību apmierināšanas procesā.

Jēdzienu un ideju skaidrojums saskaṇā ar SEMPRE projekta orientāciju uz praktisko lietderību ir lakonisks, jo skaidrojuma mērḳis ir radìt formu, kurā iekḷaujams praktiskās rīcības saturs. Tas nozīmē, ka projekta īstenošanā un pārskatā par projektu apzināti izslēgti centieni, cik vien iespējams plaši un visaptveroši sniegt teorētisko izklāstu par jēdzienu un ideju vēsturi un pieejām to skaidrošanā. Tā vietā vien raksturota jēdzienu un ideju būtība, lai tie līdzīgi bākai kalpotu par cel̦vedi praktiskai rīcībai.

Teorētiskais karkass par iesaistǐšanu un iesaistīšanos ir balstīts uz humānistisko cilvēka dabas izpratni, kas nozīmē cieņu pret indivīdu, ticību indivīdam, uzskatu, ka indivīds spēj definēt savas dzìves situāciju, viņam ir tiesības to mainìt, viņam piemìt spēks to mainìt un viņam ir vai viņš var iegūt zināšanas un prasmes, kā to mainīt (Schrötter Johannsen, 2018).

\section{Līdzdalīgās metodes sociālo pakalpojumu galalietotāju vajadzību apzināšanā}

Sociālo pakalpojumu galalietotāju iesaistī̌sana savu vajadzību apmierināšanas procesā tiek iesākta ar viņu iesaistī̌sanu savu vajadzību apzināšanā.

SEMPRE projekta ietvaros partneriem ir piedāvātas četras metodes, kā apzināt viṇu dažādo mērķgrupu vajadzības, atbilstoši spēcināšanas idejai iesaistot pašus sociālo pakalpojumu galalietotājus. Partneri vēlas rūpēties par dažādām sociālām grupām, kurām palīdzība ir nepieciešama, un sniegt tām palīdzīgu roku, un viṇi ir izvēlējušies atšḳirīgas metodes, kā noskaidrot šo grupu vajadzības.

Ziemel̦vācijas Evaṇgêeliski luteriskās baznīcas dienests darba lietās (Kirchlicher Dienst in der Arbeitswelt, KAD) ir lietojis ātro līdzdalīgo 
novērtējumu (participatory rapid appraisal), Jiveskiles Universitātes konsorcija pārstāvji Kokolā (University of Jyväskylä, Kokkola), Somijā, ir iecienijuši izmantot mugursomas metodi (backpack method), Zviedrijas konsultatīvā ekonomiskā apvienība sociālās uzṇēmējdarbības jautājumos Coompanion Nord dod priekšroku nākotnes darbnīcas metodei (future workshop) un loğiskās strukturēšanas pieejai (logical framework approach). Turpinājumā ìss katras piedāvātās metodes apraksts, kas balstās uz partneru iesūtīto informāciju.

\section{1. Ātrais līdzdalīgais novērtējums (participatory rapid appraisal)}

Ātrais līdzdalīgais novērtējums ir ērti izmantojama metode, ja nepieciešams ātri novērtēt situāciju, ņemot vērā kopienas un/vai sociālo pakalpojumu galalietotāju zināšanas un viedokḷus. Metode labi noder attīstības projektu un programmu plānošanā un ìstenošanā. Kopienas un/vai sociālo pakalpojumu galalietotāju iesaiste ne tikai veicina kāda projekta attīstību, bet arī spēcina pašu kopienu un/vai sociālo pakalpojumu galalietotājus. Ātrais līdzdalīgais novērtējums iesaista iedzīvotājus savas problēmsituācijas novērtēšanā, sasniedzamo mērķu izvirzišanā un sasniegtā novērtēšanā. Vadmotīvs šai metodē ir ideja, ka sociālo pakalpojuma galalietotāji paši ir savu dzīves situāciju eksperti.

Ziemel̦vācijas Evaṇgéliski luteriskās baznīcas dienests darba lietās šo metodi ierasti lieto, strādājot kopā ar studentiem un noskaidrojot ilgstošo bezdarbnieku vajadzības. Šāda pētijuma laika grafiks ir sadalīts tā, ka, intensīvi un kopīgi strādājot vienu nedēḷ, šai nedēḷā divas dienas tiek veltītas studentu sagatavošanai, lai veiktu intervijas, trīs dienas noris intervijas un kopīgas aktivitātes ar kopienu un/ vai sociālo pakalpojumu galalietotājiem, un divas dienas tiek veltītas iegūtās informācijas apstrādei, interpretācijai un prezentācijām, uz kurām aicināti gan sociālo pakalpojumu sniedzēji, gan galalietotāji. Prezentācijās tiek ieteikts izmantot radošu pieeju un vizuālas metodes, veidot dialogu starp uzaicinātajiem pakalpojumu sniedzējiem un pakalpojumu galalietotājiem. Šīs metodes pozitīvie aspekti ir šādi: rezultāts iegūstams ātri - jau nedēlas laikā, iesaistītie studenti parasti ir motivēti, sociālo pakalpojumu galalietotāji - patīkami pārsteigti par studentu entuziasmu un radošumu rezultātu prezentēšanā, prezentācijas pasākumā veidojas dialogs starp sociālo pakalpojumu sniedzējiem 
un galalietotājiem. Negatīvie aspekti ir apjomīgais darbs, kas nepieciešams, lai sagatavotu visu nepieciešamo intensivajai darba nedēḷai, - it sevišķi, lai iesaistītu universitātes administrāciju un lai tā atbalstìtu studentu iekḷaušanu. Izvēelētā nedēḷa pētījuma veikšanai ir lielā mērā atkarīga no universitātes mācību grafika. Arī sociālo pakalpojumu galalietotāju sasniegšana un iesaistišana var sagādāt grūtības. Rezultātu izmantošana un konkrēto identificēto nākamo soḷu realizācija atkarīga no pakalpojuma sniedzēju interesēm un motivācijas.

\subsection{Mugursomas metode (backpack method)}

Mugursomas metodi ir izmantojuši SEMPRE projekta Somijas partneri, strādājot ar bēgliem. Ši metode palīdz veidot sadarbību ar sociālo pakalpojumu galalietotājiem, šajā gadījumā - ar bēgliem. Tiek veidota kopīga darba grupa, kurā iesaistās gan sociālo pakalpojumu sniedzēji, gan pakalpojumu galalietotāji. Šai darba grupai tiek organizētas kopīgas sapulces un tikšanās, kurās tiek izskaidrots par pieejamiem pakalpojumiem, tiek uzklausīta pakalpojumu lietotāju pieredze un vēlmes, tiek veidota sadarbība un diskusija. Vajadzību noskaidrošanā var tikt veikta vienkārša aptauja un tikt organizēta paplašināta diskusija, tajā iesaistot nevalstiskas organizācijas (NVO) vai asociāciju pārstāvjus, kas ir ieinteresēti šìs sociālo pakalpojumu lietotāju kategorijas dzīves kvalitātes uzlabošanā, kā arī citus cilvēkus ar līdzīgu pieredzi. Par mugursomas metodi to sauc tādēl, ka pats pirmais jautājums, kas bēgliem parasti tiek uzdots, ir jautājums "Kas bija jūsu mugursomā, ko pañēmāt līdzi no mājām?". Bēglus var lūgt parādìt kādu no šìm lietām vai izstāstīt par tām, ja viņi to vēlas. No dzimtām vietām līdzi ņemtais var būt ne vien materiālas lietas, ko var parādīt, bet arī kaut kas simbolisks vai kāda ideja. Mugursoma ir drīzāk iztēles ideja par sev nozīmīgo vērtību krātuvi, nevis reāla soma. Nākamie jautājumi, kas seko pirmajam, ir: "Ko jūs šodien liktu savā mugursomā? Kas mugursomas saturam ir nācis klāt? Kas jums šobrīd ir nozīmīgs?" Pēc atbildēm uz šiem jautājumiem seko ieskatī̌sanās nākotnē. Bēgliem tiek uzdoti jautājumi par to, ko, vinuprāt, nākotnei noderīgu vajadzētu ielikt savā mugursomā. "Kas jūs būsiet pēc pieciem vai desmit gadiem? Kas kavē realizēt jūsu ieceres?" - ir turpmākie jautājumi. Tad kopā ar citiem darba grupas dalībniekiem, balstoties uz atbildēm par šiem jautājumiem, tiek iezīmēta vēlamā nākotnes perspektīva un tās sasniegšanai nepieciešamās 
darbības. Šajā metodē ḷoti svarīga ir pakalpojumu lietotāju iesaistī̌̌anās un vēlme līdzdarboties. N̦emot vērā iespējamās valodas barjeras, sekmīgam dialogam var būt nepieciešams tulks. Vizuālas metodes var palīdzēt attēlot tagadējo un nākotnes saturu, kas ņemts līdzi mugursomā.

\subsection{Nākotnes darbnīca (future workshop)}

Nākotnes darbnīca ir viena no SEMPRE projekta Zviedrijas partnera lietotajām metodēm. Tā ir grupas intervija ar mērkgrupas pārstāvjiem - sociālo pakalpojumu galalietotājiem. Metode sastāv no trīs secīgiem posmiem jeb fāzēm. Pirmā ir kritiskā fāze, otrā - fantāzijas fāze un trešā ir isstenošanas fāze.

Kritiskās fāzes laikā intervijas dalībnieki izsaka savas bažas, stāsta par sarežǵījumiem savā dzīvē, viṇu pašreizējās problēmsituācijas izraisa "prāta vētru". Tāpēc tiek skaidri formulētas vairākas problēmas, kas skar visus grupas intervijas dalïbniekus. Problēmas ieteicams uzrakstìt uz tāfeles vai uz līmlapām, kas novietojamas dalībniekiem redzamā vietā.

Fantāzijas fāze ir iespēja attīstīt vīziju par to, kāda būtu labāka pasaule. Pirmajā fāzē izteiktā kritika tiek mainīta pret pozitīvām idejām un ieteikumiem. Idejas tiek apspriestas un attīstìtas, ja nepieciešams, darbojoties mazākās grupās.

İstenošanas fāzē notiek kopīga diskusija par fantāzijas fāzē izstrādātajām vīzijām. Te būtiski apspriest praktiskos soḷus, kas ḷautu tuvināties šo vīziju realizācijai, izstrādāt rīcības plānu, pārrunāt konkrētas ieteicamās rīcības. Ideāls variants ir tāds, kurā kopīgo sadarbību var turpināt, koordinējot un realizējot nākotnes darbnīcā veidoto rīcības plānu. Zviedrijas partneri izmanto tikai šis metodes pirmo - kritisko fāzi, lai izzinātu aktuālās problēmas un vajadzības. Viṇi uzsver, ka liela nozīme ir nākotnes darbnīcas vadītājam. Viṇa ziṇā ir veidot labu atklātības un kopīgas diskusijas atmosfēru šai darbnīcā.

Nākotnes darbnīcas metode tika dalieji izmēgināta divās grupas intervijās Liepājā. Vienreiz nākotnes darbnīca tika organizēta telpās personām ar invaliditāti, kas regulāri satiekas. Otrā nākotnes darbnīca bija domāta personām ar invaliditāti, kas iepriekš nav sadarbojušās, un tā notika vasarā dārzā pie Liepājas Mākslas muzeja. Atklātība un aktīva interese izstāstīt savu stāstu bija raksturīga abām nākotnes darbnīcām. Ievērojami vieglāk bija strādāt ar tiem, kas iepriekš bija tikušies un 
pieraduši kopīgi darboties, jo arī grupas darbs prasa iemaņas, kas jāizkopj. Grupā, kuras locekḷi nebija iepriekš tikušies, dominēja individuālāks diskurss, katrs vairāk stāstīja nekā uzklausīja. Arī nākotnes darbnīcas vadītāja ar šo grupu darbojās pirmo reizi. Secinājums ir tāds, ka vieglāk organizēt diskusiju un orientēties uz konkrētiem uzdevumiem bija nākotnes darbnīcā, kas notika telpās.

\subsection{Logiskās strukturēšanas pieeja (logical framework approach)}

Loǵiskās strukturēšanas pieeja ir deviṇu soḷu metode. Pirmais solis ir projekta konteksta analīze. Otrais solis ir iesaistìto un ieinteresēto pušu (stakeholders) analīze. Trešais solis - problēmas analīze. Ceturtais solis - mērķu analīze. Piektais solis - aktivitāšu plāna izstrāde. Sestais solis - resursu ieguves plāna izstrāde. Septītais solis - indikatoru noteikšana. Astotais solis - risku analīze. Devìtais solis ir pieñēmumu analīze. Vajadzību apzināšana notiek pirmajos trīs soḷos. Projekta konteksta un iesaistito pušu analīze ir priekšdarbi, ko var veikt nelielā darba grupā. Tie veido kontekstu trešajam solim. Problēmas analīze notiek kopā ar pakalpojumu galalietotājiem un iesaistītajām un ieinteresētajām pusēm, iegūstot pēc iespējas dažādākus skatijumus uz problēmu. Vispirms problēma ir jādefinē. Te SEMPRE projekta Zviedrijas partneri kā piemēru min iedzivotāju skaita samazināšanos lauku regionos. Nākamais solis ir strukturēt cēloṇus un sekas, ko var attēlot kā koku, kam saknes ir problēmas cēloṇi, stumbrs - pati problēma, bet zari ir problēmas sekas. Lai to paveiktu, diskusijas dalībnieki sadalās divās grupās, kur viena grupa apkopo idejas par cēloṇiem, otra - par sekām. Cēloṇi minētajā piemērā par iedzīvotāju skaita samazināšanos laukos ir, piemēram, darbavietu trūkums un infrastruktūras nepietiekamība. Savukārt šì procesa sekas ir mazāki nodokḷu ieņēmumi reǵiona pašvaldībā, spējīgāko un gudrāko kopienas pārstāvju aizbraukšana. Katru ideju uzraksta uz atsevišķas līmlapas. Cēloṇu līmlapas salīmē pie saknēm, bet seku lapas pie zariem, izveidojot "problēmas koku". Tas palīdz vizualizēt, kā lietas ir saistītas, un iegūt labāku priekšstatu par situāciju kopumā. Lai novērstu nevēlamas sekas, ir jārisina tie jautājumi, kas ir seku cēloṇi.

Mērḳu analīze notiek līdzīgi, skatot to struktūru kā "mērķa koku", kur saknes ir darbïbas, kas nepieciešamas, lai sasniegtu mērķi, bet zari ir pārmaiņas, ko mērķa sasniegšana var dot. Zviedrijas partneri atzīmē, 
ka grūtākais šajā pieejā ir panākt visu pušu aktīvu līdzdalību viedokḷu un ideju paušanā. Vieglāk ir panākt iesaistǐšanu trešajā solī, ja dalībnieki jau tikuši iesaistīti plānošanas procesā vai ir strādājuši kopā ar kādu no vadītājiem. Dažkārt var būt nepieciešams problēmu analizēt vispirms atseviški ar sociālo pakalpojumu galalietotājiem, lai viṇus iedrošinātu paust domas un idejas grupā kopāa ar citiem.

\section{Labas prakses piemēri sociālo pakalpojumu galalietotāju iesaistī̌sanā}

Pilsoṇu iesaistǐšana un iesaistī̌̌anās kopīgās sociālās dzīves veidošanā un norisēs ir demokrātiskas sabiedrības pazīme.

2017. gada oktobrī SEMPRE projekta partneri tika aicināti savstarpēji dalīties ar reāliem piemēriem, kā vinu valstī līdz šim ir tikusi realizēta sociālo pakalpojumu saṇēmēju iesaiste konkrētu sociālo pakalpojumu sniegšanā un spēcināšanas procesā kopumā. Aicinājuma mērḳis bija apkopot praktiskas pieredzes stāstus, lai iedrošinātu un iedvesmotu citus. Rezultātā septiṇi projekta partneri atsūtīja informāciju par savām aktivitātēm. Šeit apkopots neliels ieskats iesaistišanas un iesaistǐšanās un sociālās spēcināšanas aktivitāšu dažādībā. Piemērs no Igaunijas ir aktivitāte, kas veikta SEMPRE projekta ietvaros. Seši citi partneri (trīs no Vācijas, pa vienam no Dānijas, Somijas un Latvijas) te aprakstìto labo praksi ir realizējuši citos projektos.

\subsection{MarktTreff (Vācija)}

MarktTreff ir vācu valodas saliktenis. Tajā der Markt nozīmē 'tirgus', der Treff - 'satikšanās'. MarktTreff ir sadarbïbas tìkls, kas jau 17 gadus darbojas Šlēsvigas-Holšteinas federālajā zemē Vācijas ziemelıos. Tā mērḳis ir nodrošināt dažādu pakalpojumu pieejamību lauku reǵionos. MarktTreff ir savdabīga, speciāli veidota tirgus vieta, kur vienkopus atrodamas gan preces un pakalpojumi, gan informācija, idejas un iniciatīvas. Tā rada iespēju koncentrēt vienuviet dažādos piedāvājumus, kā arī rada darbavietas, nodrošina informācijas apriti un kalpo kā kopienu spēcinoša aktivitāte. MarktTreff ir satikšanās punkts. Tas ir mūsdienīgs tirgus, kur līdztekus ierastajām precēm tiek 
piedāvāta, piemēram, interešu izglìtība, veselības aprūpes pakalpojumi, kur ir iespējams uzlādēt vai salabot mobilo telefonu. Te ir pieejami kurpnieka, friziera, vel̦as mazgātavas, bankas vai pasta pakalpojumi un notiek interesanti pasākumi, kuros var pavadìt brīvo laiku un satikt līdzcilvēkus. Tieši MarktTreff dzīvīgums un plašā iespēju un piedāvājumu dažādība ir lielākais ieguvums, ko šis sociālais tirgus sniedz kopienām lauku reğionos.

Šlēsvigas-Holšteinas federālajā zemē 2017. gada oktobrī darbojās 38 MarktTreff vietas. Tiek plānots to skaitu palielināt līdz 50. Katra vieta ir atškirīga un atbilst konkrētās kopienas interesēm un vajadzībām. Kopienas iedzīvotāji to vērtē kā pozitīvu iniciatīvu, kas uzlabo vinu dzīves kvalitāti. MarktTreff iniciatore bija Šlēsvigas-Holšteinas federālās zemes valdība, kas sabiedrībā aktīi veicināja sadarbību, aicināja biznesa sektoru un dažāda profila nevalstiskās organizācijas iesaistīties projekta attīstībā. Katras MarktTreff vietas mērḳis ir tās ekonomiska ilgtspēja. To lielā mērā nodrošina pārtikas veikals, kas ir galvenā uzṇēmējdarbības forma šajās vietās.

\subsection{Prasmju kalve (Dānija)}

Prasmju kalve ir projekts, kas no 2012. līdz 2016. gadam tika īstenots Fredericijā (Fredericia), Dānijā. Tā ietvaros cilvēki ar garīgās attīstỉbas traucējumiem (persons with learning disabilities) tika mācīti par mentoriem, lai vini varētu palīdzēt citiem cilvēkiem ar garīgās attīstības traucējumiem apgūt ikdienā noderīgas prasmes un iemaņas. Projekta gaitā līdzās apgūtajām prasmēm būtisks blakus ieguvums ir mācību un mācišanas procesa pozitīvais iespaids uz dalíbnieku pašapziṇu un prieks par panākumiem. Projekta mērḳis bija paplašināt skatījumu uz mentora lomu, l̦aujot palūkoties uz to kā uz daudzpusīgu un vienojošu praksi kopā ar cilvēkiem, kam ir garīgās attīstības traucējumi.

Par vietējiem prasmju kalves centriem tika izraudzìtas četras vietas - nodarbinātības centrs, divas sociālās mājas un viena kafejnīca, kas ir tikšanās vieta tām personām ar garīgās attīstības traucējumiem, kuras dzīvo patstāvīgi. Katrā prasmju kalves centrā tika iesaistīti divi darbinieki, kas jau strādāja uz vietas, kā arī izraudzītas divas vai trīs personas ar garīgās attīstības traucējumiem, lai viņus mācìtu par mentoriem. Mācītie mentori, profesionālo darbinieku atbalstīit, palīdzēja attīstīt noderīgas iemaņas citām personām ar garīgās attīstības 
traucējumiem. Tā tika apgūta, piemēram, kafijas pagatavošana bez citu palīdzības. Prasmju kalvju centru dalībnieki, tiekoties reizi mēnesī, veidoja kopīgu sadarbības tīklu, lai pārrunātu līdzšinējo pieredzi un turpmākās aktivitātes.

Projektu atbalstīja vietējā pašvaldība, Attīstības asociācija (Udviklingshommedes Landsforbund, ULF) un Dānijas personu ar garīgās attīstības traucējumiem savienība. Attīstības asociācijas mērḳis ir padarīt redzamu dažādo cilvēku pieredzi un stāstus, veidot iekḷaujošu sabiedrību. Prasmju kalves projekts beidzās 2016. gadā, kad pašvaldībā tika veiktas organizatoriskas pārmainas. Projekts bija atkarīgs no tajā iesaistīto cilvēku intereses uzlabot šìs sociālo pakalpojumu lietotāju kategorijas dzīves apstākḷus un no vinu nesavtīguma. Administratīvās reformas izraisītā nestabilitāte projekta darbībai nebija labvēlīga. Attīstỉbas asociācijas paspārnē tika dibināta atbalsta grupa, lai turpinātu projekta iestrādnes pēc 2016. gada, kad projekta finansējums beidzās.

\subsection{ICT-Café (Somija)}

ICT-Café ir aktivitāte, kuru Somijā kopš 2015. gada organizē Korsholmas (Korsholm/Mustasaari) zviedriski runājošo pensionāru asociācija. ICT-Café seniori ar dažāda līmeņa informācijas un komunikācijas tehnolog̣iju zināšanām atbalsta un māca citus seniorus, kas ir mazāk prasmīgi informācijas un komunikācijas tehnologiiju lietotāji. ICT-Café apmeklētāji, savstarpēji cits citam palīdzot, apgūst dažādu ikdienā noderīgu digitālo aplikāciju izmantošanas prasmes, iemācās izveidot profilu sociālajā medijā Facebook, apgūst un izmēǵina pieeju banku un veselības pakalpojumiem tiešsaitē. ICT-Café var piedalīties ikviens, iepriekšēja reǵistrācija nav nepieciešama. Katras kopā sanākšanas saturu nosaka paši dalībnieki. ICT-Café ir guvusi plašu atsaucību.

ICT-Café panākumi balstās uz idejas vienkāršību un reālo nepieciešamību vecāka gadagājuma cilvēkiem apgūt informācijas un komunikācijas tehnologiju prasmes un tās lietot. Viṇi sanāk kopā, iepriekš vienojoties par tikšanās laiku. Kafija un draudzīgā atmosfēra palīdz veidot piederības sajūtu un iedrošina iesaistīties. Iedrošinājums un atbalsts ir būtisks, jo ir tādi seniori, kas baidās kḷūdīties, jūt nedrošỉbu, lietojot informācijas un komunikācijas tehnologiijas. Tas, ka vecāka gadagājuma cilvēki māca citus seniorus, palīdz veidot labāku savstarpējo kontaktu un atrast piemērotus un saprotamus veidus, kā paskaidrot 
interesējošo tēmu. Pēc regulāriem apmeklējumiem vairāki dalībnieki ir patiesi ieinteresēti iegūt zināšanas un turpina mācības augstākas sarežgîtības informācijas un komunikācijas tehnoloğiju kursos.

\subsection{Domu fabrika (Vācija)}

Domu fabrika (Denkfabrik - vācu valodas saliktenis, kurā vārds denken nozīmē 'domāt', die Fabrik - 'fabrika') ir mazāk aizsargāto sociālo grupu forums. Tas darbojas Štutgartē, Vācijā, sociālā uzṇēmuma "Jaunais darbs" (Sozialunternehmen Neue Arbeit GmbH) paspārnē. Viens no Domu fabrikas darbības virzieniem ir pētniecība, kas veidota kā spēcinoša un iesaistoša aktivitāte šai mērḳgrupai.

Veiksmīgs Domu fabrikas līdzdalības pētijuma piemērs ir darbs ar ilgstošiem bezdarbniekiem, kuri ir politiski pasīvi un nepiedalās vēlešanās. Veikt pētījumu rosināja novērojums, ka vēlēšanās mazāk aktīvi ir cilvēki ar zemākiem ienākumiem. Ilgstošie bezdarbnieki ir plaši pārstāvēti zemo ienākumu grupā. Viṇi no paša sākuma tika iesaistīti pētijjuma procesā un piedalījās interviju jautājumu izstrādē, intervēšanas procesā un veiktā pētijuma novērtēšanā. Pētījuma empīrisko datubāzi veidoja 70 intervijas. Mērḳgrupas iesaistǐšana visos pētījuma posmos nodrošināja to, ka socioloǵisku datu, analīzes un pārskatu kopumā netika pazaudēta cilvēku individuālā pieredze un dzīves gājums. Papildus intervijām mērķgrupas pārstāvji savu pieredzi dokumentēja fotogrāfijās un attēlos. Rezultātā tapa emocionāli uzrunājošs materiāls, kas jau ir apcelıjojis trīs izstāžu vietas. Pēc pētījuma publicēšanas un tā prezentācijām vairākās konferencēs mērḳgrupas pārstāvjiem tika sarīkota diskusija ar politikas veidotājiem. Aktīvā iesaistǐšanās un informācija par pētijumu deva pārliecību, ka viṇu viedoklis ir nozīmīgs un vinu iesaistī̌sanās politikas procesos var tās veidošanu ietekmèt.

Domu fabriku atbalsta Bādenes-Virtembergas federālās zemes valdība, federālā programma "Sociāla līdzdalība darba tirgū", Federālā nodarbinātības un sociālo lietu ministrija, Štutgartes Nodarbinātības dienests un Nacionālā loto loterija.

\section{5. "Latvijas Kustība par neatkarīgu dzīvi” (Latvija)}

Biedrība "Latvijas Kustība par neatkarīgu dzīvi” pārstāv personu ar invaliditāti intereses un vajadzības. Biedrības mērḳis ir veicināt 
iekḷaujošas sabiedrības attīstību un nodrošināt vienlīdzīgas iespējas ikvienam sabiedrības loceklim. Īpaša uzmanība tiek pievērsta tam, lai sasniegtu cilvēkus ar garīgās attīstības traucējumiem un multiinvaliditāti. Biedrība ir dibināta 2009. gadā. Sākotnēji bija tikai neformālas tikšanās ar personām, kam ir invaliditāte, un informācijas apmaiņa ar viņiem un viṇu tuviniekiem. Kopš 2013. gada šì biedrība ir Eiropas Sociālo pakalpojumu sniedzēju personām ar invaliditāti asociācijas (European Association of Service Providers for Persons with Disabilities, EASPD) biedre. Biedrība "Latvijas Kustība par neatkarīgu dzīvi" ir piemērs tam, kā no nelielas iniciatīvas izaug organizācija, kas ir nozīmīgs sociālais partneris politikas procesos un lēmumu pien̦emšanā.

Biedrība piedāvā dienas centra pakalpojumus bērniem ar invaliditāti, ir izveidojusi atbalsta grupas vecākiem un aprūpētājiem, organizē kopīgu dzīves telpu - grupu dzīvokḷus personām ar garīgās attīstības traucējumiem, uztur atbalsta darbnīcas. Viena no atbalsta darbnīcu aktivitātēm ir sveču liešana. Tajā piedalās biedrības dienas centra apmeklētāji - personas ar dažādiem garīgās attīstības traucējumiem. Kopīgi darbojoties, viņiem ir iespējams socializēties, un veidošanas un radī̌sanas process stiprina viṇu pašapziņu un l̦auj justies noderīgiem. Šobrīd sveču liešanas aktivitāte, kas aizsākās interešu grupā, ir attīstījusies un ir radīts sociāls uzṇēmums.

\section{6. (Dārz)kopība (Vācija)}

Šì projekta oriğinālais nosaukums ir G(a)arden(ing). Nosaukums ir veidots kā vārdu spēle, kas sapludina angḷu valodas vārdu gardening 'dārzkopība' un K̦iles rajona Gaarden nosaukumu. G(a)arden(ing) ir dārzkopības projekts Vācijā. Projekts norisinājās no 2013. līdz 2016. gadam, dārza izveidē iesaistot bērnus un jauniešus, it sevišḳi no mazāk aizsargātām sociālām grupām. Jaunieši tika iesaistīti teritorijas plāna izveidē, teritorijas sakopšanā, dobju veidošanā, sēšanā, stādī̌anā, ravēšanā, laistǐšanā un ražas novākšanā un sadališsanā projekta noslēgumā. Lai īstenotu ekoloǵisku pieeju, dārza izveidē tika izmantoti tikai pārstrādājami un atkārtoti izmantojami materiāli. Projekta mērḳis bija veicināt gados jauno migrantu, it sevišḳi marginalizēto romu un sintu, integrāciju sabiedrībā. Kopīgā darbā un komunikācijā, kurā piedalījās arī vietējie iedzīvotāji, veidojās jauniešu imigrantu sociālais kapitāls un spēcināšanas izjūta. 
Projekta iniciatore bija profesore no Ķiles augstskolas (Kiel University of Applied Sciences, Fachhochschule Kiel - Hochschule für Angewandte Wissenschaften), kas ideju aizguva no citiem sociālās dārzkopības projektiem Vācijā. Projekta G(a)aden(ing) realizācijā aktīvi iesaistijās augstskolas pedagogijas studenti. Projektu atbalstija Ķīles pašvaldība un viena nevalstiskā organizācija. Ķīles pašvaldība projekta realizācijai ierādīja zemes gabalu, kas pieder pilsētai. Projekta G(a)rden(ing) devumu sociālās integrācijas procesā nodrošināja mijiedarbība ar vietējiem iedzīvotājiem un augstskolas studentiem, visus bagātinot ar jaunu savstarpējās mijiedarbības pieredzi.

\subsection{Filca bumbas stresa mazināšanai (Igaunija)}

Vienu no pirmajiem mikroprojektiem SEMPRE projekta ietvaros realizēja partneri no Igaunijas Evaņgēeliski luteriskās baznīcas, kas atrodas un aktīvi darbojas Harkujerves ciemā. SEMPRE projektā šì mikroprojekta mērḳis ir spēcināt cilvēkus, kam ir invaliditāte, it sevišḳi gimenes ar bērniem, kam ir invaliditāte.

Mikroprojekta aizsākumu rosināja informācija, ko uzzināja kopīgās sarunās ar mērķgrupas pārstāvjiem, proti, ka daži vecāki saviem bērniem ir noadījuši nelielas bumbas ar mîkstu pildījumu. Bērniem patīk ņurcīt šìs pašdarinātās bumbas, un tās ietekmē bērnus kā stresu mazinošs līdzeklis. Mazinās trauksmes sajūta un iekšèjs sasprindzinājums. Mīkstās, elastīgās bumbas, tās turot plaukstās, kairina receptorus un tā palīdz nomierināties un koncentrēties.

Igaunijas Evaṇgêeliski luteriskās baznīcas pārstāvji organizēja mācības un darbnīcu, kur jauni cilvēki ar garīgās attīstìbas traucējumiem iemācījās izgatavot līdzīgas bumbas no filca. Gatavais produkts tālāk tika nodots bērniem ar invaliditāti, kā arī tirgots labdarības tirdziņā, kur tās ieguva lielu atsaucību un labi pirka.

Filca bumbu izgatavošanas pulciņa izveide palīdzēja gan bērniem ar invaliditāti, kas ieguva papildu līdzekli trauksmes sajūtas mazināšanai, gan tiem cilvēkiem ar garīgās attīstības traucējumiem, kuri apguva jaunu prasmi, guva kopīgas darbošanās prieku un gandarījumu par paveikto.

Šobrīd Harkujerves Evaņgèliski luteriskā baznīca nodrošina septiņu dažādu radošo pulciņu darbību, arī teātra un dejas nodarbības. Ar domubiedru atbalstu un palīdzỉbu ir sakopta teritorija ap baznīcu un iekopts dārzs. 
Labas prakses piemēri sociālo pakalpojuma lietotāju iesaistī̌nanai sociālo pakalpojumu sniegšanā un spēcināšanas procesā kopumā, ko piedāvā SEMPRE projekta partneri, rāda dažādas iespējas, kā domāt par spēcināšanu un iesaistī̌sanu un iesaistī̌šnos. Visos mikroprojektos tiek veicināta cilvēku savstarpējā komunikācija, kas var būt gan informācijas apmaiṇa, gan kopīga jaunu prasmju apgūšana vai kopīga darbu veikšana.

\subsection{Mikroprojekti, kas SEMPRE projekta ietvaros īstenoti Kurzemes regionā ${ }^{1}$}

Liepājas Diakonijas centrs kā SEMPRE projekta partneris Kurzemes regiionā ir ierosinājis īstenot piecus mikroprojektus. Mikroprojekti ir iecerēti un apspriesti sadarbībā ar novadu sociālajiem dienestiem, personām ar invaliditāti un citām iesaistītajām un ieinteresētajām pusēm. Atbilstoši SEMPRE projekta idejai veicināt sociālu spēcināšanu lauku reǵionos mikroprojekti tiek realizēti nevis Liepājā, bet Kurzemes regiona lauku iedzivotājiem novadu un pagastu centros Grobiṇā, Bārtā, Dubeṇos, Rucavā un Durbē. Mikroprojekti ir plānoti, pārrunāti, aizsākti un attīstīti, kopīgi darbojoties vietējos sadarbỉbas tîklos.

Saskan̄ā ar Liepājas Diakonijas centra pārstāvju Mārtiṇa Urdzes un Karīnas Krieviṇas sniegto informāciju SEMPRE projekta ietvaros Kurzemes reǵionā no 2016. līdz 2019. gadam tiek īstenoti pieci mikroprojekti. To īstenošanas vietas ir Grobiṇa, Bārta, Dubeṇi, Rucava un Durbe.

Grobiṇā labiekārto Tikšanās dārzu personām ar invaliditāti, kur varētu satikties un kopīgi nodarboties ar dārza darbiem, rīkot nelielus pasākumus, būt kopā ērti pieejamā un sakoptā vidē. Projekta ietvaros izveidota atbalsta grupa "Kopā būt", kurā kopā ar personām ar invaliditāti aktīvi darbojas arī Sarkanā Krusta organizācija un tās Grobiṇas nodaḷas personāls, Grobiṇas novada Sociālais dienests, Grobiṇas Evaṇ̂gēliski luteriskās baznīcas diakonija, kā arī citu iesaistīto un ieinteresēto pušu pārstāvji. Šis mikroprojekts risina tādas personu

Informāciju par mikroprojektu īstenošanu Kurzemes regionā snieguši Karīna Krieviṇa un Mārtiņš Urdze (A. S.). 
ar invaliditāti vajadzības kā nepieciešamība pēc pozitīviem sociāliem kontaktiem un jēgpilnas laika pavadīšanas.

Projekta izpildes sākumstadijā 2017. gada maijā ar pašvaldību tika risināts jautājums par aț̣auju izmantot zemes gabalu līdzās Sarkanā Krusta èkai. Nākamais uzdevums ir sarīkot puḳu stādu un krūmu stādu dāvināšanas pasākumu.

Bārtā tiek veidota Baskāju taka, kam materiāli sarūpēti kopīgos izbraukumos un talkās. Tie ir oḷi, akmeņi, koka ripiņas, zīles, kastaņi, šḳelda. Ar Bārtas pagasta Sociālā dienesta palīdzību uzrakstīts projekts pašvaldības atbalsta pasākumiem. Projektā kopā ar Grobiṇas novada personām ar invaliditāti līdzdarbojas pašvaldības Sociālais dienests, Bārtas pagasta pārvalde, Bārtas kultūras nams, ir cieša sadarbība ar Grobiṇas novada atbalsta grupu "Kopā būt". Arī šajā mikroprojektā tiek radīta iespēja pozitīvu sociālo kontaktu uzturēšanai un jēgpilnai laika pavadī̌sanai.

Projekta izpildes sākumstadijā 2017. gada maijā notiek pārrunas ar pašvaldību par vietu, kur Baskāju taka varētu tikt izveidota, tiek plānoti komunikācijas pasākumi, lai pievērstu sabiedrības uzmanību šim projektam.

Grobiñas novada Duben̦os mikroprojekta uzdevums ir iekārtot vienkāršu uzbrauktuvi pie daudzdzīvokḷu nama ieejas, tā risinot vides pieejamības jautājumu. Šai namā ir atvēlētas telpas lūgšanu kapelai un atbalsta grupas tikšanās vietai. Pie nama ieejas ir pakāpieni, kas apgrūtina vides pieejamību cilvēkiem ratiņkrēslos. Šajā gadījumā uzmanība ir vērsta uz vajadzību patstāvīgi pārvietoties telpā, tātad uz vides pieejamību, kas ir nozìmīga komponente citu vajadzību apmierināšanai.

Mikroprojekta izpilde sākusies 2017. gada maijā, izveidojot tā īstenošanas plānu un nosakot soḷu secību tā īstenošanai.

Rucavā personu ar invaliditāti atbalsta grupa "Cerību stariņš" veido recepšu krājumu vienkāršu, lētu un garšìgu èdienu pagatavošanai. Mikroprojekta dalībnieki paši gatavo èdienus, izmantojot produktus no Eiropas Savienības pārtikas pakām, kas domātas trūcīgiem cilvēkiem, kā arī citus ikdienā pieejamus produktus. Receptes tiek apspriestas un pierakstìtas, lai tās apkopotu un publicētu. Šàds recepšu krājums būs noderīgs arī citām atbalsta grupām un interesentiem, kas ir līdzīgā trūcīgo un maznodrošināto personu statusā. No vienas puses, šis mikroprojekts palīdz apmierināt pamatvajadzību pēc èdiena ierobežotu resursu apstākḷıs. No otras puses, tas apmierina vajadzību pēc 
pozitīviem sociāliem kontaktiem, jaunrades un kopā būšanas. Rucavas novada Sociālais dienests aktīi līdzdarbojas šai mikroprojektā no paša atbalsta grupas veidošanas pirmsākuma.

2017. gada maijā mikroprojektā tiek kopīgi izmēǵinātas un pierakstītas receptes, lai sakopoto krājumu publicētu brošūrā. Mikroprojekta dalībnieki - personas ar invaliditāti - ir l̦oti apmierinātas ar šo kopdarbošanos.

Durbē mikroprojekta ietvaros veido mācību kursu un organizē mācības brīvprātīgajiem asistentiem, kas palīdzētu personām ar invaliditāti tikt galā ar dažādām lietām. Mācībās ir iekḷautas dažādas praktiskas un teorētiskas nodarbïbas, kas to dalībniekiem dod iespēju palīdzēt citiem, strādājot par asistentiem. Mācỉbu programmā ir iekḷauts pirmās palīdzības kurss, sociālās likumdošanas kurss par personu ar invaliditāti tiesībām un pienākumiem, fizioterapeita konsultācija, nodarbības par saskarsmes psiholog̣ijas tematiem. Ir oficiāli reǵistrēta Durbes atbalsta biedrība personām ar invaliditāti, to sauc "Roku rokā". Šajā mikroprojektā vajadzība attīstīties un jēgpilni pavadìt laiku tiek risināta līdztekus vajadzībai pēc palīdzības un sociāliem kontaktiem.

Mikroprojektā plānotās nodarbības ir uzsāktas 2017. gada maijā. Durbes pašvaldība ir solījusi sniegt atbalstu ar transportu. Lìdzekḷi degvielas iegādei ir jāmeklē. Ir iecere, ka pēc mācību beigšanas katrs to dalībnieks atrod aprūpējamo, kam palīdzēt. Turpmākais atbalsts dalībniekiem plānots supervīziju veidā.

Sākotnēji Kurzemes regiionā tika plānots attīstīt pa vienam mikroprojektam Grobiṇā, Rucavā un Priekulē. Visos trīs novados ir izveidojusies laba sadarbība ar sociālajiem dienestiem. Sadarbỉbas tīklam attīstoties, Grobiṇas novadā radās trīs atbalsta grupas - Grobiṇā, Bārtā un Dubeņos. Redzot sociālo pakalpojumu galalietotāju un citu iesaistīto pušu ieinteresētību un reālās vajadzības, mikroprojektu programmu šeit tika nolemts paplašināt. Tā kā atbalsta grupas Bārtā un Dubeņos izveidojās vēlāk, tad arī projektu izpilde tur ir agrīnākā stadijā. Savukārt Priekules atbalsta grupa turpina darboties jau šobrīd piedāvātajos pašvaldības pasākumos, kā arī aktīivi iesaistās SEMPRE projekta sadarbības tīkla sapulcēs un pasākumos, mikroprojektam atvēlētos līdzekḷus atstājot jaunizveidoto atbalsta grupu plānotajiem pasākumiem. Šādai elastīgai pieejai ir lielāks kopējais ieguvums, kā arī tā stiprina sadarbības saites starp atbalsta grupām. 
SEMPRE projekta mērḳis ir palīdzēt sociālo pakalpojumu sniedzējiem attīstìt mūsdienīgus sociālos pakalpojumus. Sociālo pakalpojumu galalietotāju spēcināšana, iesaistīšana un iesaistǐšanās ir nozīmīgi mūsdienīgu sociālo pakalpojumu izveides faktori. Tie ne tikai veicina konkrētā uzdevuma izpildi vai pakalpojuma radīšanu, bet arī sniedz iemaņas citu problēmsituāciju risināšanai un pakalpojumu galalietotājiem dod pārliecību par pašu iesaistī̌sanās svarīgumu. Vietējo sadarbỉbas tīklu veidošana un sadarbỉbas praktizēšana ir viens no atbalsta pasākumiem, ko Liepājas Diakonijas centram ir izdevies realizēt. Mārtiņš Urdze un Karīna Krieviña uzsver, ka tas ir laikietilpīgs process, kas prasa pacietību un iejūtību: "Vajadzīgs laiks, lai viens ar otru iepazìtos, atklāti dalītos ar savām vajadzībām un problēmām, kopīgi meklētu risinājumus, kā atbalstìt vienam otru, izmantojot tos resursus, kas ir pieejami konkrētajā vietā."

Kurzemes regiona mikroprojekti ir veidoti un attīstīti, skrupulozi sekojot idejai par sociālo pakalpojumu sniedzēju, galalietotāju un citu iesaistīto un ieinteresēto pušu kopdarbošanos. Idejas par mikroprojektiem netika pasniegtas gatavas. Tās meklētas un pārrunātas sadarbības tîklu sapulcēs. Tika veidota vide, kur rasties un attīstīties mikroprojektu idejām. Tā ir atzinīgi vērtējama iesaistī̌sanas un spēcināšanas prakse, kurā mikroprojektu idejas un iniciatīvas tika pacietīgi meklētas un izaudzētas jaunizveidotajos vietējos sadarbïbas tîklos. Tas ir prasījis daudz laika, tādēḷ mikroprojektu realizēšana nenotiek tik ātri, kā sākotnēji plānots. Tā kā SEMPRE projekta galvenais mērḳis ir sociālo pakalpojumu sniedzēju spēcināšana, lai viṇi spēcināšanu pārnestu uz sociālo pakalpojumu galalietotājiem, tad mikroprojekti ir rīki, kas to palīdz ìstenot. Šādā kontekstā ir uzteicama projekta partnera - Liepājas Diakonijas centra - pacietība un neatlaidíba. Visi pieci mikroprojekti vērtējami kā SEMPRE projekta idejai un mērḳiem atbilstoši.

Nākotnē plānojot šādus uz sociālo iesaistīšanu un spēcināšanu balstìtus projektus, jāṇem vērā, ka sociālo pakalpojumu galalietotāju sasniegšana un iesaistī̌sana aktivitātēs, tāpat kā kopīgas sadarbỉbas veidošana iesaistīto un ieinteresēto pušu starpā, ir laikietilpīgs process. Tomēr tieši pats process ir būtiska spēcināšanas komponente. Ideju meklēšana un attīstī̌̌ana atbalsta grupās, kas jau ir ne tikai iesaistī̌̌ana, bet arī pašu dalībnieku iesaistīšanās, savukārt, dod lielāku ticamību mikroprojektu ilgtspējai un atbalsta grupu aktivitāšu turpinājumam pēc SEMPRE projekta noslēguma. 


\section{Divpadsmit mikroprojekti SEMPRE projekta partnerības ${ }^{2}$ valstīs (īstenoti līdz 2018. gada jūlijam)}

\section{1. Šlēsvigas-Holšteinas diakonija (Vācija)}

Šlēsvigas-Holšteinas diakonijas darbinieki ir îstenojusi trīs mikroprojektus.

Pirmais mikroprojekts ir tīmekḷa vietnes izveidošana viena vecāka gimenēm. Tā ir nosaukta par AllDi. Tās mērḳis ir piedāvāt noderīgas informācijas klāstu, iespēju sadarboties, komunicēt un kooperēties viena vecāka ğimenēm. Tiek veidota organizācija, kas nodrošinātu vietnes darbību un aktuālās informācijas plūsmu, kā arī veidotu kodolu komandas darbam kopā ar sociālo pakalpojumu sniedzējiem. Vecāku atsaucíba un interese apgūt jaunas iemaņas un zināšanas ir negaidīti liela. Sākumā sociālo pakalpojumu sniedzējiem trūka entuziasma, šobrīd visi projekta dalībnieki ir ieinteresēti un aktīvi iesaistījušies. Procesā ir nācies saskarties ar aizspriedumiem gan par projekta iniciatīvām, gan par viena vecāka gimenēm. Pirms šì mikroprojekta pastāvēja interneta vietne viena vecāka ğimenēm reǵionā. Tā kā informācija tajā netika atjaunota, tā bija zaudējusi aktualitāti. Šobrīd vecāki paši kopīgā darba grupā veido vietni, kas atbilstu viṇu vajadzībām. Šãda mikroprojekta attīstǐšana prasa daudz laika. Spēcināšana ir laikietilpīgs process, kur nepieciešama liela pacietỉba, tādēl būtiski ieplānot pietiekami daudz laika gan idejas realizācijai, gan attīstībai.

Otro mikroprojektu sauc “"Veselības tīkls" viena vecāka gimenēm” ("health network" for single parents). Veselības tìkla mērḳis ir rūpēties par veselību, mazināt stresu ikdienas rutīnā un laika trūkumā, veicināt sociālo mijiedarbību, sniegt atbalstu pašaprūpei un organizēt sociālās sadarbības tīklu, piemēram, jogas nodarbības. Pirmais redzamais ieguvums ir tas, ka šie vecāki vairāk aizdomājas par savu veselību un iespējām to stiprināt. Šajā mikroprojektā sociālo un veselības pakalpojumu sniedzēju iesaistī̌sana grūtības nesagādāja. Organizējot apạ̄ā galda

Otrais cipars šai sadaḷā norāda partnera numerācijas secību projekta pieteikumā. Visi partneri mikroprojektus nav ìstenojuši, tādēḷ skaiț̣i, kas norāda partnera numuru, neveido secīgu rindu (A. S.). 
diskusijas, notika veiksmīga domu apmaiņa, tika rasti interesanti risinājumi. Pagaidām lielākās grūtības ir bijušas, lai nodrošinātu pašu vecāku iesaistišanos mikroprojekta veidošanā, organizēšanā un turpināšanā.

Trešā mikroprojekta mērḳis ir nodrošināt bērnu pieskatīšanas pakalpojumu tad, kad vecāks, kurš viens audzina bērnus, dodas uz konsultāciju pie ārsta. Šāds pakalpojums uzlabo veselības aprūpes pieejamību šiem vecākiem.

\subsection{Ziemeḷvācijas Evañgéliski luteriskā baznīca (Vācija)}

Šis projekta partneris ir izveidojis ilgstošo bezdarbnieku atbalsta grupu Wirkstatt (darbošanās vieta). Šì mikroprojekta galvenais uzdevums bija izveidot un iedzīvināt vietu, kur ilgtermiņa bezdarbnieki varētu tikties ar citiem cilvēkiem līdzīgā situācijā, komunicēt un sadarboties, kopīgi atpūsties bez papildu izmaksām, iesaistīties pieredzes apmain̄ā. İstermiṇa ieguvums ir pašapziņas celšana, pārliecības par sevi nostiprināšana. Ilgtermiṇā tiks veidots kas līdzīgs politiskai pārstāvniecībai, mācību platforma un forums. Pagaidām šie mērḳi ir sasniegti dal̦ēji. Projekts ir labi zināms reg̣ionā. Tie dalībnieki, kuru situācija ir mainijusies uz labo pusi un kuriem atbalsta grupa vairs nav nepieciešama, no mikroprojekta izstājas. Interesi par iesaistišanos mikroprojektā ir izrādijjuši vairāki jauni sociālo pakalpojumu sniedzēji. Kopumā darbs ir gana sarežg̀îts, jo atbalsta grupa ir trausla un heterogēna. Nav viegli saskaņot ilgstošu un ḷoti ilgstošu bezdarbnieku mērḳus, kas ievērojami atškiras. Wirkstatt dod iespēju darba devējiem satikt potenciālos darbiniekus.

\section{3. Šlēsvigas-Holšteinas Ekonomikas akadēmija (Vācija)}

Šis partneris mikroprojektu ir īstenojis, izveidojot mācību uzṇēmumu, kas bēgliem palīdz iesaistīties darba tirgū. Tajā tiek mācìta vācu valoda, tādējādi racionāli izmantojot gaidīšanas laiku, kamēr tiek veiktas dažādas ar bēgḷu statusa iegūšanu saistītas procedūras. Vajadzību apzināšanā tika noskaidrots, ka ir l̦oti daudz laika, kad bēgliem vienkārši jāgaida, kamēr notiek dažādas birokrātiskas procedūras - tiek apstiprināts bēg̣̣a statuss vai organizēta atgriešanās uz savu izcelsmes valsti. Mikroprojektā tiek piedāvāta iespēja uzsākt darba gaitas arī sievietēm. Lai arī izcelsmes valstīs bēgḷu sievietes lielākoties algotu darbu 
nestrādā, bet rūpējas par māju un bērniem, tomēr vajadzību apzināšanās sarunās sievietes izrādīja aktīvu interesi par iespējām iesaistīties darba tirgū un integrēties Vācijas sabiedrībā. Viṇas ir pamanījušas, ka Vācijā sievietes loma ir citādāka nekā vinu izcelsmes valstīs. Izglìtības līmenis bēglēm no Sirijas ir atškirīigs. Dažas bēgles ir studējušas, bet ir arī tādas, kas neprot lasìt un rakstīt. Projektā piedalās abu dzimumu bēg̣̣i. Viṇiem palīdz apgūt vācu valodu un tiek sniegts atbalsts darba meklēšanā. Sarežǵîtākais šajā mikroprojektā ir starpkultūru komunikācija un saprašanās. Te jāmācās abām pusēm: gan iebraucējiem, gan vietējiem iedzīvotājiem - vāciešiem.

\subsection{Lietišķo zinātņu augstskola Novia (Somija)}

Šîs augstskolas mikroprojekta mērḳis ir apkopot vecāka gadagājuma cilvēkiem noderīgu informāciju no dažādiem avotiem, lai viṇi vienuviet varētu skatīt informāciju par interesantiem pasākumiem un noderīgām aktivitātēm. Tāds digitāls rīks varētu veicināt vecāka gadagājuma cilvēku līdzdalību pasākumos un mazināt vinu vientulību. Šim nolūkam ir radīts kalendārs internetā - vienkāršs digitāls instruments, ar kura palīdzību var vieglāk iegūt informāciju par notikumiem un iespējām reǵionā. Pakalpojumu sniedzēji šo digitālo instrumentu var izmantot pasākumu plānošanai. Tāpat tas var būt noderīgs dažādu jomu pārstāvju sadarbības veidošanai un plānošanai. Kalendārs sniedz kopskatu par regionā plānotajiem notikumiem un tādējādi palīdz ieraudzīt jomas un laika posmus, kuros aktivitāte ir zemāka un tāpēc ir iespējams vai nepieciešams iekḷaut papildinājumus. Šobrīd ir grūti novērtēt, cik veiksmīgs ir šis mikroprojekts, jo tikai pēc ilgāka laika varēs redzēt, vai kalendārs joprojām tiek izmantots, regulāri papildināts un tālāk attīstīts. Vecāka gadagājuma cilvēkiem, kuriem ir digitālā pratība, šis rīks palīdz uzzināt par pasākumu piedāvājumu un plānot savas aktivitātes. Vajadzība pēc prasmes darboties internetā arvien pieaug, un, iespējams, šis vienkāršais digitālais rīks var arī iedrošināt šos cilvēkus apgūt internetpratību.

\subsection{Jiveskiles-Kokolas Universitātes konsorcijs Chydenius (Somija)}

Šis projekta partneris mikroprojektu ir îstenojis divās daḷās. Sākumā ir uzņemta videofilma par migrantu prasmēm. Pēc tam ir 
nodibināta afgāṇu imigrantu NVO. Afgāṇu kopienai Kokolā nebija telpu, kur organizēt kopīgas tikšanās. Universitātes konsorcijs tās piedāvāja, kā arī uzklausīja vajadzības, palīdzēja veidot komunikāciju, plānot aktivitātes un dibināt NVO. Afgāņu kopienu iedrošināja tas, ka šajā projektā arī viṇi paši tiek sadzirdēti. Pēc pusgada kopīga darba un diskusijām tika nolemts dibināt NVO. Mikroprojektā afgāṇu imigrantiem tika mācīts, kā noris demokrātisks lēmumu pieṇemšanas process, kā pieteikties fondu projektiem, kā vadīt NVO. Tāpat tas veicināja līdzdalību dažādās aktivitātēs, kas tika rīkotas pilsētā. Jaundibinātā NVO sadarbojas ar pilsētas domi. Demokrātiska lēmumu pieñemšanas procesa apgūšana un funkcionējoša rīcībspēja Somijas kontekstā ir ārkārtīgi nozīmīga prasme, kas noteikti ir jāapgūst imigrantiem, kuri nokḷuvuši šajā valstī.

\subsection{Luterāṇu diakonija (Lietuva)}

Lietuvas partneru veidotā mikroprojekta galvenais uzdevums ir identificēt viena vecāka gimenes un veidot to savstarpējas saiknes, organizēt pasākumus, kuros var apgūt organizatoriskas, vadības un uzṇēmējdarbības prasmes. Sākumā tika apzinātas vajadzības. Atklājās, ka nopietna šo cilvēku problēma ir bailes, pašapziņas un pašpārliecinātības trūkums, kā arī neziṇa, kur vērsties pēc palīdzības. Tādēl tika nolemts organizēt kopīgu pasākumu, lai cilvēki varētu satikties un izrunāties. Tas tika noorganizēts kopā ar dažādiem sociālo pakalpojumu sniedzējiem, papildus tika nodrošinātas dažādas atraktīvas aktivitātes - friziera pakalpojumi, spēles bērniem. Pasākums izdevās veiksmīgs, un šobrīd ir plāns piesaistīt valsts un privātus finansētājus, lai šādu pasākumu rīkotu katru gadu.

Vēl šogad tiek plānota mācību programma, kurā zināšanu apguves priekšmeti būtu sociālais mārketings, mijiedarbība un komunikācija ar pakalpojumu lietotājiem, sevis prezentācijas prasmes un veiksmīgas konkurences nosacījumi darba tirgū. Lìdztekus ir izveidota laba sadarbība ar Lietuvas Nodarbinātības valsts aǵentūru, veicinot izpratni par individuālas pieejas nepieciešamību šai mērķ̧grupai. Nākotnē tiek plānots izveidot klubu, kur viena vecāka gimenes varētu tikties, gūtu atbalstu, iedrošinājumu un zināšanas vadības un uzṇēmējdarbības jautājumos. 


\subsection{Igaunijas Evaņgêeliski luteriskā baznīca (Igaunija)}

Te tiek īstenoti divi mikroprojekti. Viens mikroprojekts ir bērnudārza izveidošana, otrs ir atbalsta sniegšana no ieslodzījuma atbrīvotām personām.

Izpētot reǵiona attīstības plānu un pašvaldībā pieejamos datus, tika secināts, ka Igaunijas ziemeḷaustrumu reǵionā ir nepieciešams bērnudārzs bērniem līdz trīs gadu vecumam. Lìdz šim regionā bija pieejami bērnudārzi tikai bērniem, kas jau sasnieguši trīs gadu vecumu. Bērnu vecāki mikroprojekta ideju atbalstīja. Kopīgi ar viniem tika rīkotas diskusijas, lai labāk izprastu vajadzības šì pakalpojuma kontekstā. Būtisks arguments par labu šim mikroprojektam ir tas, ka bērnudārza pakalpojuma nodrošināšana dod iespēju vecākiem strādāt algotu darbu.

Otrā mikroprojekta mērķis ir rekrutēt un izglìtot atbalsta personas tām personām, kas atbrīvotas no ieslodzījuma. Brīvprātīgiem tiek mācītas šim darbam nepieciešamās sociālā darba prasmes. Brīvprātīgo darbs tiek sākts, personai vēl esot brīvības atņemšanas iestādē. Brīvprātīgiem tiek mācìts, kā palīdzēt ieslodzìtajiem pašiem risināt savas problēmas un radušos sarežǵỉjumus. Pēc mācībām brīvprātīgie rīko diskusiju ar ieslodzìtajiem par viṇu vajadzībām. Šì mikroprojekta mērḳis ir veidot labāku izpratni par to, kā palīdzēt personām, kas notiesātas ar brīvības atņemšanu, saprast savas problēmas, to cēloṇus un kā pašām tās veiksmīgāk risināt. Pēc kopīgām diskusijām tiek veidoti individuāli plāni dzīvei pēc ieslodzījuma. Ar valsti ir noslēgts līgums par samaksu brīvprātīgajiem. Tie ir 7 eiro stundā. Brīvprātīgajiem tiek nodrošināta supervīzija. Kaut arī sākotnēji cietuma vadība un darbinieki izrādīja piesardzỉbu un nebija atvērti šim projektam, tomēr šobrīd visi ir atzinuši, ka brīvprātīgo regulārās tikšanās ar ieslodzītajiem ir nākušas par labu videi brīivibas atņemšanas institūcijā.

\subsection{Sociālās rīcības fonds (Igaunija)}

Sociālās rīcības fonda veidotā mikroprojekta sākumā tika plānots Igaunijas ziemel̦austrumu un centrālā reǵionā organizēt nodarbību programmu skolēniem pēc mācību stundām skolā. Projekts paplašinājās, tajā iekḷaujot pasākumus pieaugušajiem. Mērḳis ir sekmēt reǵiona iedzīvotāju labklājību. Jaunākais papildinājums mikroprojektā ir bērnudārzs bērniem līdz trīs gadu vecumam. Mikroprojekta aktivitāšu rezultātā ir nostiprinājusies kopienas baznīcas ideja, kā arī 
izpratne par draudzīgas, savstarpēji izpalīdzīgas, dzīvi apliecinošas kopienas (conviviality) labvēlīgo ietekmi uz kopienas un indivīda dzīvi. Mikroprojekta rezultātā ir pieaugušas iespējas sniegt sociālos pakalpojumus regionā.

\subsection{Dienviddānijas Universitātes koledža (Dānija)}

Mikroprojekta "Kultūru šḳērsošana" (Crossing cultures) mērḳis ir darbs ar bēgliiem. Galvenā ideja ir spēcināt jaunos cilvēkus, kas Dānijā ieradušies kā bēgli, veidojot no viņu vides kodolu, kas palīdz iesaistīt citus bēgḷus un organizē viṇiem spēcināšanas aktivitātes. Šiem cilvēkiem tiek palīdzēts, dodot iespēju palīdzēt citiem, būt tiem, kas spēcina citus. Bēgḷi, kas ieradušies Dānijā, tiek iedrošināti veltīt laiku citu cilvēku atbalstī̌sanai. Mikroprojektā iesaistītie dalībnieki paši meklē līdzekḷus un atbalstītājus ieplānotajiem projektiem. Ar padomiem viņiem palīdz projekta koordinators. Piemēram, šie jaunie cilvēki spēja piesaistìt līdzekḷus un noorganizēja lieliskas brīvdienas viena vecāka gimenēm. Mikroprojektā iesaistīto un iesaistijušos grupa nu jau attīstās patstāvīgi un palīdz attīstīties citiem. Viņiem ir dažādi resursi, un viņi var palīdzēt un palīdz tiem, kam resursu trūkst. Šo bēgḷu darba rezultātā gan vini, gan citi cilvēki piederību kopienai izjūt arvien stiprāk.

Mikroprojektu apskats rāda, cik tie ir dažādi, jo dažādas ir sociālo pakalpojumu lietotāju kategorijas. Kopīgais secinājums par mikroprojektiem ir tāds, ka tie visi ir uzlabojuši dzīves kvalitāti tiem, kas iesaistījās mikroprojektu īstenošanā.

\section{Trūcīgo un maznodrošināto daudzbērnu gimeñu iesaistīšana savas labklājības veidošanas darbā Latvijā}

Noslēgumā ilustrācijai konkrēts piemērs par sociālo pakalpojumu galalietotāju iesaistīšanu savas labklājības veidošanā Latvijā.

Latvijas pilsoniskās sabiedrības pārstāvji (NVO), pašvaldības un privāts fonds ir devuši iespēju trūcīgām un maznodrošinātām gímenēm izaudzēt sev pārtikai dārzeņus, ogas un aug̣̦us. Tā ir iesaistišanas iniciatīva sava dārza iekopšanā, lai ar sava darba ieguldījumu 
pašvaldību pieškịirtos zemes gabalos un ar citu cilvēku sagādāto sēklu materiālu un nepieciešamāko inventāru lielā mērā nodrošinātu sevi un savu gimeni ar pārtiku.

\section{Latvijas trūcīgo un maznodrošināto daudzbērnu gimeņu iesaistīšana rīcībā, lai spēcinātu savu labklājību}

Šis ir piemērs par Latvijas lokālās spēcināšanas tīklu sarūpēto un piedāvāto iespēju sociālo pakalpojumu galalietotājiem iesaistīties pārtikas sagādē savai ǵimenei. Šo iespēju nodrošina nevalstiskās organizācijas, lauku apdzīvoto vietu pašvaldības un Borisa un Ināras Teterovu fonds kā izdevumu finansētājs. Projekta mērksgrupa ir trūcīgās un maznodrošinātās daudzbērnu gimenes, kas dzīvo laukos un lieto sociālos pakalpojumus. Borisa un Ināras Teterovu fonds sociālo pakalpojumu lietotāju iesaistišanu un spēcināšanu finansē, izveidojot šim nolūkam finansējuma programmu "Pats savam saimes galdam". Programma visā Latvijas lauku teritorijā darbojas kopš 2017. gada, un tiek plānots to îstenot trīs gadus. 2018. gadā lokālās spēcināšanas organizācijas tika aicinātas līdz 31. janvārim pieteikties finansējuma saņemšanai no fonda un vienlaicīgi ar pieteikumu iesniegt izdevumu tāmi par to, ko nepieciešams iegādāties, lai nodrošinātu darbošanos tām gimenēm un atsevišḳiem indivīdiem, kas pauduši gribu iesaistīties.

Atbalsta sniegšanā trūcīgām un maznodrošinātām daudzbērnu ǵimenēm laukos ir iesaistîti un ieinteresēti vietējo pašvaldību sociālie dienesti, lokālās sabiedriskās organizācijas, kopienu fondi, religískās organizācijas un Borisa un Ināras Teterovu fonds, kas piekritis šo iniciatīvu un projektu finansēt. Šĩ pasākuma norisi organizē lokālā sociālās spēcināšanas tīkla organizācija, kas ir atbildīga par programmas "Pats savam saimes galdam" īstenošanu. Tā informē un uzaicina iesaistīties tos vietējos iedzīvotājus, kam pašu darbs un piedalǐšanās šādā programmā sniegtu jūtamu atbalstu pārtikas nodrošināšanā. Programma "Pats savam saimes galdam" par brīvu piedāvā dārzeņu un kartupeḷu sēklas, augģ kocinus un ogu krūmus, dažos gadījumos arī minerālmēslojumu un kaut ko no lauksaimniecības inventāra, lai trūcīgās daudzbērnu ǵimenes un atsevišķi iedzīvotāji varētu izaudzēt 
sev pārtiku. Tā tiktu sagādāta nozīmīga pārtikas daļa. Sadarbības tīkla organizācijas apzina un uzaicina iesaistīties sociālo pakalpojumu galalietotājus, pašvaldības piešķir lietošanā zemi, kur ierīkot dārzu. Tā, izmantojot piedāvāto iespēju par brīvu saņemt visu nepieciešamo darbam, pieņemot šo piedāvājumu, sociālo pakalpojumu galalietotāji reǵionos ar savu darbu var kḷut labāk nodrošināti, materiāli un psiholoǵiski labklājīgāki un pašapziñā spēcīgāki.

Statistiskie dati rāda, ka 2017. gadā šajā programmā iesaistījās 436 trūcīgās un maznodrošinātās daudzbērnu ǵimenes, aptverot 1581 cilvēku, to skaitā 778 bērnus, 21 Latvijas novadā. Šìs ǵimenes saimniekoja uz $400 \mathrm{~m}^{2}$ zemes un izaudzēja 86000 kg dārzeņu. Visbiežāk audzēja kartupel̦us, sīpolus, burkānus, tomātus, bietes un gurk̦us.

2018. gadā šĩ programma netika īstenota, bet tā atsāks darbu 2019. gadā.

Avots: Borisa un Ināras Teterovu fonds aicina klūt par saimniekiem savam saimes galdam. Pieejams: www.teterovufonds.lv [28.01.2018., 02.01.2019.].

\section{Secinājumi}

Iesaistǐšana un iesaistî̌sanās ir sabiedrības demokrātiskas pārvaldības un varas sadalīšanas un pārdalīšanas instruments.

Iesaistī̌̌ana un iesaistīšanās sociālās labklājības sfērā ir pieeja, kas ir aktualizēta kā inovatīvs instruments, jo sociālo pakalpojumu jomā kādu laiku tas nav ticis izmantots kā pārmainu instruments un dzīves kvalitāti uzlabojoša sociālā tehnolog̣ija.

Apzinoties nepieciešamību aktivizēt sociālo pakalpojumu galalietotāju domāšanu un rīcību, lai viṇi aktīvi veiktu pārmaiṇas savā dzīves situācijā, viṇi sākumā kopā ar nozares profesionāliem ir iesaistāmi savu vajadzību apzināšanas procesā.

Praksē ir pierādīts, ka vienkāršas un efektīvas iesaistī̌̌anas metodes savu vajadzību apzināšanā ir, pirmkārt, ātrais līdzdalīgais novērtējums, otrkārt, tā dēvētā mugursomas metode, treškārt, nākotnes darbnīca un, ceturtkārt, loğiskās strukturēšanas pieeja. 
Vajadzību apzināšanai seko praktiska rīcība, lai apmierinātu patiesi nepieciešamās vajadzības.

Kā iespējamais iedvesmas avots pārdomām par rīcību, rīcības plānošanai un pašai praktiskai rīcībai rakstā ir sniegta virkne labas prakses piemēru no SEMPRE projekta partnerības valstu pieredzes un SEMPRE projekta partneru īstenoto mikroprojektu prakses, kā pašu spēkiem uzlabot dzīves un vides kvalitāti.

Kopumā cilvēku iesaistîšana un iesaistǐšanās aktīvā rīcībā var zināmā mērā mainīt un uzlabot sociālo pakalpojumu galalietotāju dzīves apstākḷus gan lauku, gan pilsētas vidē.

\section{Atsauces}

Borisa un Ināras Teterovu fonds aicina klūt par saimniekiem savam saimes galdam. Pieejams: www.teterovufonds.lv [skatits: 28.01.2018., 02.01.2019.].

Elisheva, S. Empowerment and Community Planning. Part 1. Developing a Theory of Empowerment. Available: www.mpow.org/elisheva_sadan_empowerment_ part1_intro.pdf [accessed: April 8, 2018.].

Elisheva, S. Empowerment and Community Planning. [b.g.] 350 p. Available: http:// www.mpow.org/elisheva_sadan_empowerment.pdf [accessed: May 4, 2018.].

Schrötter Johannsen, G. (2018) Empowerment. The Power to Name - the Power to Act. Handouts in Workshop in Esbjerg on February 26, 2018.

\section{leteicamā literatūra un avoti papildu informācijai par iesaistǐšanu un iesaistǐšanos ${ }^{3}$}

\section{Grāmatas, rokasgrāmatas, brošūras}

Aldridge, J. (2015) Participatory Research: Working with Vulnerable Groups in Research and Practice. Policy Press.

Barnes, M., Cotterell, P. (2012) Critical Perspectives on User Involvement. The Policy Press.

Beresford, P. (2012) Social Care, Service Users and User Involvement (Research Highlights in Social Work Series). Jessica Kingsley Pub.

Literatūras un avotu sarakstu par iesaistǐšanu/iesaistǐ̌anos veidojušas Evija Zača, Laura Jaunromāne un Anna Stepčenko. Sarakstu sakārtojusi atbilstoši bibliogrāfijas normām Līva Upena (A. S.). 
Branfield, F., Beresford, P. with contributions from Andrews, E. J., Chambers, P., Staddon, P., Wise, G., Williams-Findlay, B. (2006) Making User Involvement Work: Supporting Service User Networking and Knowledge. Joseph Rowntree Foundation. Available: https://www.jrf.org.uk/sites/default/files/jrf/migrated/ files/1410-user-networking-knowledge.pdf.

Community-Based Participatory Research: A Guide to Ethical Principles and Practice (2012) Centre for Social Justice and Community Action, Durham University; National Co-ordinating Centre for Public Engagement (United Kingdom).

Croft, S., Beresford, P. (1993) Citizen Involvement: A Practical Guide for Change (Practical Social Work Series). Palgrave Macmillan.

Greenhalgh, T., Humphrey, C., Woodard, F. (2011) User Involvement in Health Care. Blackwell Publishing Ltd.

Kaasinen, E., Ainasoja, M., Vulli, E., Paavola, H., Hautala, R., Lehtonen, P., Reunanen, E. (2010) User Involvement in Service Innovations. VTT. Available: http://www.vtt.fi/inf/pdf/tiedotteet/2010/T2552.pdf.

Lowes, L., Hulatt, I. (2005) Involving Service Users in Health and Social Care Research. Routledge.

Participation Toolkit (2013) Available: http://www.feantsa.org/spip.php?article 122\&lang=en; available in following languages: English, Catalan, French, German, Polish, Spanish.

Payne, M. (2014) Modern Social Work Theory (4th ed.). Basingstoke: Palgrave Macmillan.

Roy, H. (2015) User Participation and Empowerment Toolkit. Eurodiaconia.

Social Innovation: The Role of Social Service Providers (2012) Social Services Europe.

Tyler, T. R. (2011) Why People Cooperate: The Role of Social Motivations. Princeton University Press.

Trotter, C. (1999) Working with Involuntary Clients: A Guide to Practice. Sage Publications.

Warren, J. (2007) Service User and Carer Participation in Social Work. SAGE.

\section{Raksti}

Beresford, P., Croft, S. Service Users' Knowledge and the Social Construction of Social Work. Journal of Social Work. Vol. 1, No. 3, December 2001, pp. 295-316. Doi: 10.1177/146801730100100304.

Cossar, J., Neil, E. Service User Involvement in Social Work Research: Learning from an Adoption Research Project. British Journal of Social Work. Vol. 45, No.1, 2015, pp. 225-240. Doi: 10.1093/bjsw/bct108.

Cowden, S., Singh, G. The 'User': Friend, Foe or Fetish?: A Critical Exploration of User Involvement in Health and Social Care. Critical Social Policy. Vol. 27, No. 1, February 2007, pp. 5-23. Doi: 10.1177/ 0261018307072205. 
D'Cruz, H., Gillingham, P. Participatory Research Ideals and Practice Experience: Reflections and Analysis. Journal of Social Work. April 22, 2016. Doi: $10.1177 / 1468017316644704$.

Fleming, J., Beresford, P., Bewley, C., Croft, S., Branfield, F., Postle, K., Turner, M. Working Together - Innovative Collaboration in Social Care Research. Qualitative Social Work. Vol. 13, No. 5, September 2014, pp. 706-722. Doi: $10.1177 / 1473325013506929$.

Kujala, S. User Involvement: A Review of the Benefits and Challenges. Behaviour \& Information Technology. 2003, pp. 1362-3001. Doi: 10.1080/ 0144929021000055530.

Kvarnström, S., Hedberg, B., Cedersund, E. The Dual Faces of Service User Participation: Implications for Empowerment Processes in Interprofessional Practice. Journal of Social Work. Vol. 13, No. 3, May 2013, pp. 287-307. Doi: $10.1177 / 1468017311433234$.

Littlechild, R., Tanner, D., Hall, K. Co-research with Older People: Perspectives on Impact. Qualitative Social Work. Vol. 14, January 1, 2015, pp. 18-35. Doi: $10.1177 / 1473325014556791$.

Loughran, H., McCann, M. E. Employing Community Participative Research Methods to Advance Service User Collaboration in Social Work Research. British Journal of Social Work. Vol. 45, No. 2, 2015, pp. 705-723. Doi: 10.1093/ bjsw/bct133.

Mclaughlin, H., Brown, D., Alys, M. Young Consultation, Community and Empowerment: Lessons from the Deaf Community. Journal of Social Work. August 2004. Doi: 10.1177/1468017304044859.

Smith, M., Gallagher, M., Wosu, H., Stewart, J., Cree, V. E., Hunter, S., Evans, S., Montgomery, C., Holiday, S., Wilkinson, H. Engaging with Involuntary Service Users in Social Work: Findings from a Knowledge Exchange Project. British Journal of Social Work. Vol. 42, No. 8, 2012, pp. 1460-1477.

Storm, M., Hausken, K., Knudsen, K. Inpatient Service Providers' Perspectives on Service User Involvement in Norwegian Community Mental Health Centres. International Journal of Social Psychiatry. Vol. 57, No. 6, November 2011, pp. 551-563. Doi: 10.1177/0020764010371270.

West, S. A., Griffin A. S., Gardner, A. Social Semantics: Altruism, Cooperation, Mutualism, Strong Reciprocity and Group Selection. Journal of Evolutionary Biology. Vol. 20, No. 2, March, 2007, pp. 415-432. Doi: 10.3410/ f.1071807.524727.

\section{Interneta resursi}

Homepage of European Social Network. $\rightarrow$ Page: Empowering people with disabilities through service-user participation. Available: http://www.essc-eu. org/essc-workshops/empowering-people-with-disabilities-through-serviceuser-participation/.

Homepage of Social Services Europe. $\rightarrow$ Page: PESSIS - Promoting employers' social services in social dialogue. Available: http://www.socialserviceseurope. $\mathrm{eu} / \#$ !pessis-/c7pr. 


\section{Raksti internetā}

Active Inclusion of People with Disabilities: the Role of Public Social Services. Available: http://www.esn-eu.org/news/729/index.html.

'Complaints, Legal Assistance and Rights Information Tool for You'. Available: http://www.socialplatform.org/news/complaints-legal-assistance-and-rights-information-tool-for-you/.

Decentralisation at the Crossroads. Available: http://www.esn-eu.org/news/802/ index.html.

Empowering Communities for Better Outcomes. Available: http://www.esn-eu. org/news/804/index.html.

Fundamental Rights Based Governance. Available: http://www.socialplatform. org/blog/fundamental-rights-based-governance/.

How can Social Care Providers Involve Service Users? Available: https://www. theguardian.com/social-care-network/2014/may/22/social-care-providers-involve-service-users.

Integrated Services for People with Disabilities. Available: http://www.esn-eu. org/news/600/index.html.

Integrated Social Services in Europe. Available: http://www.esn-eu.org/ news/746/index.html

Involvement of People with Disabilities: the Key to Adequate, Person-Centred Services? Available: http://www.esn-eu.org/news/769/index.html.

Local Partnerships for Social Inclusion. Available: http://www.esn-eu.org/news/ 801/index.html.

Local Strategies for Social Cohesion. Available: http://www.esn-eu.org/news/ 800/index.html.

Partnership between the Public Sector and Civil Society: Win-Win for Social Services. Available: http://www.socialplatform.org/blog/partnership-betweenthe-public-sector-and-civil-society-win-win-for-social-services-1/.

Quality, Person-Centred Services for People with Disabilities. Available: http:// www.esn-eu.org/news/561/index.html.

Social Work Education Leads the Way on Involving Service Users. Available: https://www.theguardian.com/social-care-network/2014/jun/03/social-workeducation-leads-way-involving-service-users.

Stakeholder Involvement can Improve Poverty and Social Exclusion Policies. Available: http://www.socialplatform.org/news/more-ambitious-stakeholderinvolvement-for-better-policies/

Working Strategically with Service Users. Available: http://www.esn-eu.org/ news/491/index.html.

\section{Videomateriāli}

$23^{\text {rd }}$ European Social Services Conference Video. Available: https://vimeo. com/148864200. 
Closing Panel Discussion: What are the Outcomes of Integrated Services for Organisations and Service Users? Available: https://vimeo.com/147008631. CRCC Health and Wellbeing - Service User Involvement. Available: https:// www.youtube.com/watch?v=AkzPc9wHWdc.

European Social Rights Pillar: Developing Inclusive Labour Markets. Available: https://vimeo.com/177216024.

Listening to Users and Carers. Available: https://vimeo.com/10523104.

Service User Involvement: Unique and Essential. Available: https://www.youtube.com/watch?v=Ixeclxg3cAY.

The Benefits of Service User Involvement. Available: https://www.youtube. $\mathrm{com} /$ watch?v=iVAwbgTdT6A.

The MHRN and Service User Involvement. Available: https://www.youtube. $\mathrm{com} /$ watch? $\mathrm{v}=\mathrm{V} 8 \mathrm{C} 8 \mathrm{w} Y \mathrm{lPuuk}$.

The NHS: User Involvement and You. Available: https://www.youtube.com/ watch?v=5xhs0I_DInw. 
Anna Stepčenko

\title{
Sociālekonomiskā konteksta salīdzinošā analīze SEMPRE projekta spēcināšanas vietās
}

\author{
Comparative Analysis on the Socio-Economic \\ Context of the Local Empowerment Networks \\ in Rural Regions in SEMPRE Project ${ }^{1}$
}

\begin{abstract}
Summary
The comparative analysis of the socio-economic context includes the statistical data by the Eurostat on the purchasing power standards, density of population, change in population and comparison of these data between the local empowerment networks located in the eight Baltic sea region countries of the European Union. In addition to the statistical data there are analysed and compared data derived from a survey. The main issues in a questionnaire are related to the local empowerment networks' socio-economic specifics of the project partners. Other questions focus on the restricting factors that influence the life circumstances of the end-users and on the specific barriers and obstacles that social service providers face when working with the endusers. The factors which influence social service organizations' staff work conditions are divided in two groups - material and immaterial factors. The most restrictive factors due to social service organizations' staff are a large scale of the immaterial factors.
\end{abstract}

1 Latvijas Universitātei viens no projekta partnerības darba uzdevumiem bija sagatavot ang̣̣u valodā sociālekonomiskā konteksta salīdzinošo analīzi SEMPRE projekta spēcināšanas vietās. Tāpēc tika uzrakstīti divi apjomīgi raksti. Viens raksts ir par vietu sociālekonomiskā konteksta salīdzinošo analīzi. Tā kā tika padziḷināti pētìtas barjeras un šķēešlı sociālo pakalpojumu organizāciju personāla darbā, tad otrajā rakstā ir analizēta šì izpēte. Abi raksti angḷu valodā ir ievietoti SEMPRE projekta elektroniskajā datubāzē (A. S.). 
Key words: purchasing power standard, density of population, change in population, factors influencing everyday life of the end-users, barriers and obstacles faced by the staff of social service provision organizations.

\section{Kopsavilkums}

Rakstā ir veikta projekta partneru izraudzìto sociālās spēcināšanas vietu sociālekonomiskā konteksta salīdzinošā analīze. Par vietu sociālekonomisko kontekstu ir divi informācijas avoti. Viens no tiem ir Eurostat statistiskie dati par pirktspējas standartiem, iedzīvotāju blīvumu un pārmaiṇām iedzīvotāju sastāvā šajās vietās. Otrs informācijas avots ir formalizēta partneru aptauja. Tajā ir iegūtas ziṇas par vietu sociālekonomiskas specifikas raksturojumu, par ierobežojošiem faktoriem, kas ietekmē sociālo pakalpojumu galalietotāju dzīves apstākḷus. Cits jautājums ir par barjerām un šķēršliem, kas sastopami sociālo pakalpojumu organizāciju personāla darbā.

Atslēgvārdi: pirktspējas standarts, apdzīvotības blīvums, pārmaiṇas iedzīvotāju sastāvā, vietu sociālekonomiskā specifika, sociālo pakalpojumu galalietotāju dzīves apstākḷus ierobežojošie faktori, barjeras un šḳēršlı sociālo pakalpojumu organizāciju personāla darbā.

Tematika. Vietu pirktspējas standarta rādītāju salīdzinājums. Vietu apdzīvotības blīvuma rādītāju salīdzinājums. Vietu iedzīvotāju skaita pārmaiṇu rādītāju salīdzinājums. Lokālo spēcināšanas tīklu vietu sociālekonomiskās specifikas raksturojums. Sociālo pakalpojumu galalietotāju dzīves apstākḷus ietekmējošo faktoru raksturojums. Barjeras un šķēršḷi sociālo pakalpojumu organizāciju darbā. Papildinformācija par barjerām un šḳēršliem sociālo pakalpojumu organizāciju darbā, kura balstīta uz padziḷinātas barjeru un šḳēršlı izpētes datiem, kas ir iegūti Latvijā, Somijā un Vācijā.

\section{Vietu sociālekonomiskā konteksta izziṇas metodologija}

Sociālo pakalpojumu organizāciju personāla darba pienākums ir ne tikai sniegt atbalstu un palīdzēt sociāli vājām un ievainojamām grupām tikt galā ar savu dzīves situāciju, bet arī mainīt sociālo pakalpojumu lietotāju domāšanas veidu un iesaistīt tos aktīvā rīcībā, lai labvēlīgi ietekmētu viņu dzīvi un viņi nebūtu tikai pasīvi pabalstu tērētāji. Šāda relatīvi inovatīva pieeja sociālo pakalpojumu sniegšanā palīdzības efektivitātes labad ir jābalsta uz daudzveidīgām zināšanām. Šim mērḳim daudzveidīgo zināšanu klāstā noder arī zināšanas par to vietu sociālekonomiskiem apstākḷiem, kur sociāli spēcināmās grupas dzīvo. 
Informācija par vietu sociālekonomisko kontekstu tika iegūta no diviem avotiem, lietojot divas informācijas ieguves metodes. Viena no tām ir kvantitatīvo statistisko datu analīzes metode, otra ir sociālo pakalpojumu organizāciju profesionāḷ formalizēta elektroniska aptauja.

Projekta darba sākumā 2016. gada pirmajā pusē no Eurostat datubāzēm tika iegūta apjomā ierobežota interesējošā statistiskā informācija. Lìdztekus tika veikta formalizēta sociālo pakalpojumu organizāciju profesionāḷu aptauja. Aptaujā tika lūgts sniegt ìsas ziņas par trīs jautājumiem: par lokālās spēcināšanas tîkla vietu sociālekonomiskām ìpatnībām, pakalpojumu galalietotāju dzīves apstākḷu novērtējumu un barjerām un škseeršliem savā pakalpojumu sniedzēju darbā. Saņemtās atbildes lielākoties bija lakoniskas, dažas - plaši izvērstas.

Statistiskie dati par reǵioniem, kuros ietilpst SEMPRE projektā iekḷautās lokālo spēcināšanas tīklu vietas, projekta sākumposmā Eurostat datu masīvā bija apkopoti un pieejami par 2013. gadu. Rādītāju skaits ir apzināti ierobežots ar trīs rādītājiem. Pirmais rādītājs ir pirktspējas standarts konkrētā reǵionā, kas skaitliski ir izteikts procentuāli, to salīdzinot ar Eiropas Savienības vidējo rādītāju. Otrais rādītājs ir reǵionu apdzīvotības blīvums un tā dinamika. Trešais rādītājs ir iedzīvotāju skaita pārmaiṇas reg̣ionā.

Statistisko datu salīdzinošā analīze tiek veikta nosaukto informatīvo tematu secībā, katru tematu beidzot ar secinājumiem. Salīdzinošās analīzes noslēgumā ir sniegti vispārināti secinājumi un daži ieteikumi.

\section{Statistisko datu salīdzinošã analīze}

\subsection{Pirktspējas standarta rādītāju salīdzinājums ${ }^{2}$ SEMPRE projekta vietās}

Sakārtojot pirktspējas standarta rādītāju rindu dilstošā secībā, partneri un valstis izkārtojas procentuāli lejupejošā kārtībā. Par

Avots: PPS/capita in \% of EU, 2013. Available: http://ec.europa.eu/eurostat/web/ regions/data/database. Izmantoti 2016. gada pirmajā pusē pieejamie Eurostat dati. 
pirktspējas standarta vidējo rādītāju Eiropas Savienībā ir pieņemts skaitlis 100 .

Projekta partneru sociālās spēcināšanas vietās pirktspējas rādītāji izkārtojas šādā dilstošā secībā:

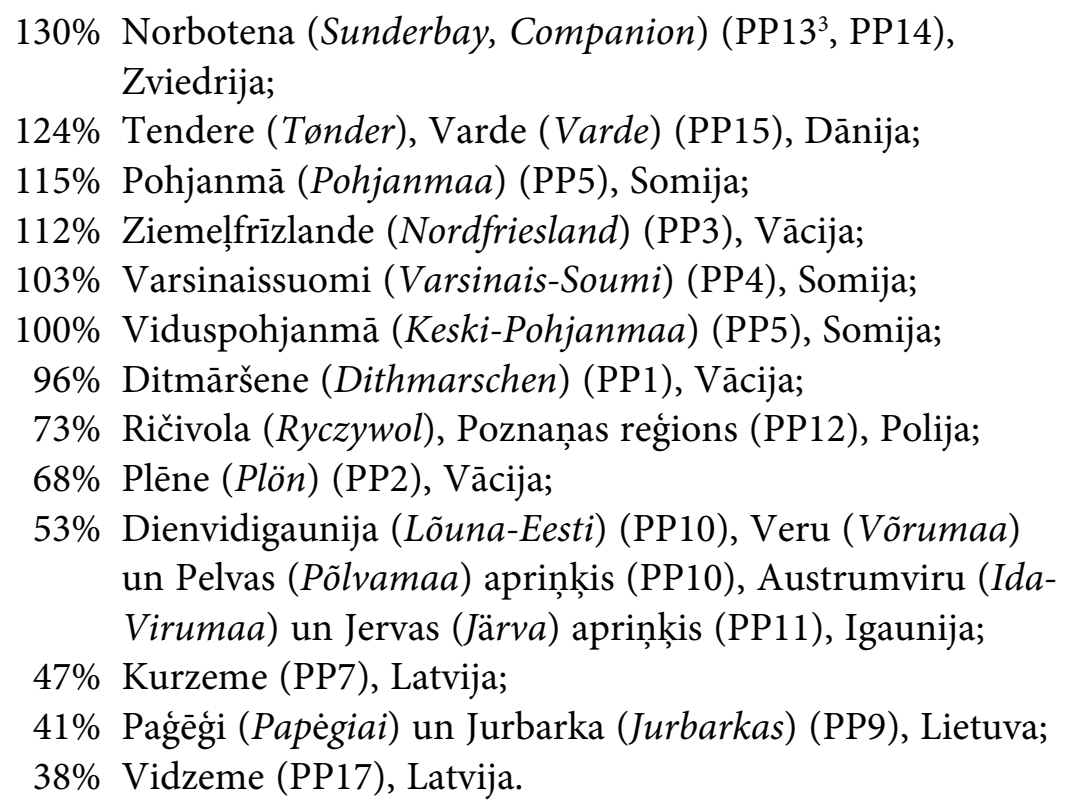

Lai arī kvantitatīvie sociālo parādību mērỉjumi ir aptuveni rādītāji, tomēr tie sniedz gana labu priekšstatu. Spēcināšanas vietās pirktspējas rādītāji rāda atšķirības. Tie uzskatāmi liecina par zināmu sociālo faktu - Skandināvijas valstu ekonomiskās un sociālās labklājības augsto līmeni, kas panākts vairāku faktoru ietekmē, ieskaitot arī labu valsts pārvaldību, valsts iekšpolitikas veidotājus un lēmumu pieņēmējus. Par Zviedriju ir piebilstams, ka šì valsts nav cietusi no Otrā pasaules kara postījumiem. Arī tāds subjektīvais rādītājs kā dažādu valstu iedzīvotāju laimes izjūta (pat ja to pārlieku nopietni neuztveram) Skandināvijas valstīs ir visaugstākais.

Šis un turpmākie šādi saīsinājumi nozīmē 'projekta partneris'. Pievienotais cipars ir partnera numurs SEMPRE projekta pieteikumā (A. S.). 
Vācija pēc sociālekonomiskiem rādītājiem pieder pie sociālās labklājỉbas valstu grupas, tomēr projektā izraudzìto vietu pirktspējas standarta rādītāji ir atšķirīgi. Tie uzrāda nevienlīdzību un neviendabību ne vien visā Vācijā, bet pat vienā federālā zemē - Šlēsvigā-Holšteinā. Ziemeḷfrīzlandes pirktspējas standarts ir augstāks par Eiropas Savienības vidējo rādītāju, turpretim Ditmāršenē tas ir nedaudz zemāks, bet Plēnē tas tuvojas Baltijas valstu rādītājiem, kas ir krietni zemāki par Eiropas Savienības vidējiem pirktspējas standarta rādītājiem. Baltijas valstu zemo pirktspējas rādītāju cēloṇi ir meklējami to vēsturiskajā attīstībā - politisko režīmu pārmaiņās, 90. gadu privatizācijā, kas tika īstenota pēc "laupìtāju likumiem", lai pēc neatkarības atgūšanas 1991. gadā iegūtu ekonomisko kapitālu. Bezatbildīgā pārvaldība l̦āva visam notikt pašplūsmā, nerūpējoties par sabiedrības kopējo labumu un attīstìbu.

\subsection{SEMPRE projekta vietu apdzīvotības blīvuma rādītāju salīdzinājums}

Apdzīvotības blīvuma rādītājs ir mērījums, ar kuru tiek izteikts vidējais iedzīvotāju skaits uz vienu kvadrātkilometru.

Ja apdzīvotības blīvuma statistiskos datus par vidējo cilvēku skaitu uz vienu kvadrātkilometru izkārto dilstošā secībā, veidojas šāda iedzīvotāju skaita uz vienu kvadrātkilometru rādītāju rinda ${ }^{4}$ :

117,2 Ričivola, Poznaņas reǵions (PP12), Polija;

117,0 Plēne (PP2), Vācija;

92,9 Ditmāršene (PP1), Vācija;

81,6 Tendere, Varde (PP15), Dānija;

77,8 Ziemeļfrīzlande (PP3), Vācija;

44,3 Varsinaissuomi (PP4), Somija;

24,2 Paǵégi un Jurbarka (PP9), Lietuva;

23,3 Pohjanmā (PP5), Somija;

20,7 Dienvidigaunija (PP10, PP11), Igaunija;

19,5 Kurzeme (PP7), Latvija;

4 Avots: Population Density, 2013. Available: http://ec.europa.eu/eurostat/web/ regions/data/database. 
13,7 Viduspohjanmā (PP5), Somija;

13,6 Vidzeme (PP17), Latvija;

2,6 Norbotena (Sunderbay, Companion) (PP13, PP14), Zviedrija.

Iedzīvotāju blīvums vienā kvadrātkilometrā uzrāda interesantu sakarību: tās vietas, kas ekonomiski labklājīgajās Skandināvijas valstīs (Somijā un Zviedrijā) ir iekḷautas SEMPRE projektā, atkarībā no to geogrāfiskā izvietojuma ziemel̦u-dienvidu virzienā uzrāda vidēji zemu apdzīvotības blivumu $(44,3)$, zemu apdzìvotības blīvumu, kas ir tuvs Baltijas valstu iedzīvotāju izkliedei $(13,7)$, un l̦oti zemu apdzīvotības blīvumu Norbotenas lēnē Zviedrijas ziemelosos $(2,6)$. Tur dzīvojošo skaits ir vidēji 2,6 cilvēki uz vienu kvadrātkilometru. Skaudrie klimatiskie apstākḷi Somijas un Zviedrijas ziemel̦u regionos ir tikpat nopietns retas apdzīvotības faktors kā skaudrie sociālekonomiskie dzīves apstākḷi, kas iekustinājuši iedzīvotāju plūsmas urbanizācijai un emigrācijai. Augstais bezdarba līmenis un sociālo pakalpojumu pieejamības samazināšanās laukos ir motivējusi darbspējīgā vecuma lauku iedzīvotājus gan pārcelties uz pilsētām, gan masveidā, pievienojoties pilsētniekiem, emigrēt no valsts. Šāda emigrācija bija vērojama pēc radikālām sociālekonomiskām pārmain̄ām 90. gadu sākumā gan Baltijas valstīs, gan dažās citās valstīs, kas pāriet uz kapitālisma formāciju. Emigrācijas plūsmas paisuma viḷni veidojās, pakāpeniski ieviešot bezvīzu pārvietošanās režīmus ar daudzām valstīm, un 2004. gadā iestājās iedzīvotāju kustības brīvība visā Eiropas Savienības teritorijā, kad Eiropas Savienībā tika uzṇemtas Baltijas valstis.

\section{3. ledzīvotāju skaita pārmaiņu rādītāju salīdzinājums ${ }^{5}$ SEMPRE projekta vietās}

Iedzīvotāju skaita pārmaiṇu rādītāji sniedz informāciju par to, kā konkrētā vietā pieaug vai samazinās iedzīvotāju skaits un kā mainās iedzīvotāju vecumstruktūra, kā pieaug vai samazinās cilvēku skaits dažādās vecumgrupās.

Avots: Relative Population Change, 2011-2015. Available: http://ec.europa.eu/ eurostat/web/regions/data/database. 
Ja statistiskos datus par iedzīvotāju skaita pārmaiṇām Eurostat statistisko vienību ietvaros salīdzina pēc relatīviem rādìtājiem, tos sakārtojot dilstošā secībā, iegūstam šādu rādītāju rindu:

$+1,80 \%$ Pohjanmā (PP5), Somija;

$+1,62 \%$ Varsinaissuomi (PP4), Somija;

$+0,75 \%$ Viduspohjanmā (PP5), Somija;

$+0,73 \%$ Ričivola, Poznan,as regions (PP12), Polija;

$+0,55 \%$ Norbotena (Sunderbay, Companion) (PP13, PP14),

Zviedrija;

$+0,20 \%$ Tendere, Varde (PP15), Dānija;

$-1,57 \%$ Ditmāršene (PP1), Vācija;

$-1,98 \%$ Ziemeḷfrīzlande (PP3), Vācija;

$-3,16 \%$ Dienvidigaunija (PP10, PP11), Igaunija;

$-5,53 \%$ Plēne (PP2), Vācija;

$-6,06 \%$ Kurzeme (PP7), Latvija;

$-6,12 \%$ Vidzeme (PP17), Latvija;

$-6,72 \%$ Paǵẹgi un Jurbarka (PP9), Lietuva.

Iedzīvotāju skaita pārmaiṇu relatīvie rādītāji tiek sadalīti divās grupās - pieauguma un samazināšanās grupā. Pieaugumu uzrāda visu Skandināvijas valstu un Polijas SEMPRE projektā iekḷautās vietas. Iedzīvotāju skaita samazināšanās notiek visās Vācijas un Baltijas valstu SEMPRE projektā izraudzītās vietās. It kā paradoksāli šķiet rādītāji par iedzīvotāju skaita pieaugumu skaudrā klimata vietās Somijā un it īpaši Norbotenas lēnē Zviedrijas ziemel̦os. Būtisks faktors, kas nosaka šo tendenci, ir šo valstu imigrācijas politika. Ekonomiskās un sociālās labklājības magnētiskā pievilcība, kas SEMPRE projektā iekḷauto valstu vidū raksturīga Skandināvijas valstīm un Vācijai, motivē uz šejieni virzīties imigrācijas plūsmai no akūto un hronisko konfliktu valstīm, kas atrodas citos kontinentos, kā arī dažu valstu eiropiešiem. Tà kā imigrantus uzṇemošās labklājīgās Ziemel̦eiropas valstis pārvalda un kontrolē imigrantu izvietošanas procesu, pārdomāti izvietojot imigrantus un sadalot tos pa visas valsts teritoriju, tad daļa bēĝ̣u un imigrantu no siltajām dienvidu un dienvidaustrumu valstīm ir nonākuši Somijas un Zviedrijas teritorijās, kur raksturīgs ilgstošs aukstums un tumsa. 
Dabiskie iedzīvotāju skaita pārmainu faktori, kas nosaka iedzīvotāju skaita samazināšanos Šlēsvigas-Holšteinas federālajā zemē Vācijā un Baltijas valstu SEMPRE projekta vietās, ir zemais dzimstības līmenis visās šajās valstīs un augstais mirstības līmenis Baltijas valstīs. Vispārēja urbanizācijas tendence, kas joprojām turpinās, ir cits faktors, kas ietekmē iedzìvotāju skaita samazināšanos lauku apdzìvotās vietās. Vienlaikus ar sen aizsākušos industrijas attīstību sākās arī urbanizācija, kas joprojām turpinās. Lauki zaudē kādu dalı no saviem jauniešiem un ekonomiski aktīvā vecuma iedzīvotājiem. Nepārtraukti notiek gados jauno un ekonomiski aktīvā vecuma iedzìvotāju iekšzemes kustība uz pilsētām, kur tiek turpināta izglìtība un ir vieglāk atrast un sasniegt darbavietu, kā arī tiek piedāvāti daudzveidīgi sociālie pakalpojumi un kultūras pasākumi.

Baltijas valstīs migrācijai uz pilsētām ir pievienojusies emigrācijas plūsma uz ārzemēm. Aizbraucēju skaits no Latvijas valsts ir dramatiski liels. Minētie faktori ir cēlonis tam, ka samazinās lauku iedzīvotāju skaits un šo iedzīvotāju vecumstruktūrā ir sākusi dominēt pirmspensijas vecumgrupa un vecuma pensijas saṇēmēju grupa.

\section{Aptaujas dati}

Partneru aptaujā par lokālās spēcināšanas tìkla vietu sociālekonomiskām īpatnībām, pakalpojumu galalietotāju dzives apstākḷu novērtējumu un barjerām un šḳēršliem, kuri pastāv pakalpojumu sniedzēju darbavietās, ir saṇemtas 14 anketas, kas aptver visas lokālo spēcināšanas tìklu vietas.

Aptaujas datu analīzes metodika ir tāda, ka iesākumā tiek uzskaitītas partneru sniegtās ziņas tādā secībā, kā tās nosaukuši partneri. Savukārt partneru secība veidota pēc to numerācijas projekta ieteikumā. Ja tā pati vai nedaudz citādi formulēta informācija par vienu un to pašu tematu atkārtojas, tā tiek pievienota, norādot partnera numuru un atrašanās vietu. Kad visa partneru sniegtā informācija par vienu jautājumu bloku ir sakārtota vienotā uzskaitījuma sarakstā, tā tiek apkopota un tiek izdarīti secinājumi. Raksta nobeigumā, kad ir apkopoti visi partneru sniegtie fakti, novērojumi vai novērtējumi, tiek doti daži ieteikumi. 


\subsection{Lokālo spēcināšanas tīklu vietu sociālekonomisko ipatnību raksturojums}

Vispirms partneriem ìsās formalizētās aptaujas anketā bija lūgums raksturot sava spēcināšanas tîkla vietas sociālekonomiskās īpatnības.

Par projektā iekḷauto vietu īpatnībām partneru atbildīgās personas ir sniegušas daudzveidīgas ziņas. Pirmās tika raksturotas ziṇas par tautsaimniecību konkrētā vietā.

Tautsaimniecỉbas ipatnības: izteikta lauku dzīves vide ar lauksaimnieciskās ražošanas dominēšanu un sezonālu nodarbinātību (Plēne/PP2, Ziemel̦frīzlande/PP3, Varsinaissuomi/PP4), kalnrūpniecības regions (Norbotena/PP13, PP14). "Šis ir ekonomiski vislabvēlīgākais regions Somijā” (Varsinaissuomi/PP4).

Bezdarbs ir izplatīta un specifiska lauku apdzivoto vietu problēma. Izñēmums ir Dānija, kur bezdarba līmenis ir zems. Par nodarbinātību un bezdarbu tiek liecināts daudz un dažādos formulējumos: "augsts bezdarba līmenis" (Ziemeḷ̂fīzlande/PP3, Viduspohjanmā un Pohjanmā/PP5, Kurzeme/PP7, Pageégi un Jurbarka/PP9, Dienvidigaunija, Veru un Pelvas apriņkis/PP10, Austrumviru un Jervas apriṇkisis/PP11), "nodarbinātības problēmas" (Dienvidigaunija/PP10, PP11), "pieaug bezdarbs migrantu vidū, ilgtermiņa bezdarbs" (Norbotena/PP13, PP14), "ierobežots vietējais nodarbinātỉbas sektors, mazas nodarbinātības iespējas laukos - alternatīvā lauksaimniecība, pārtikas ražošana, mežizstrāde, amatnieciba" (Vidzeme, PP17). Vēl par bezdarbu teikts: "augsts bezdarba līmenis jauniešiem ar zemu izglìtības līmeni un zemu pašcienu" (Norbotena, Sunderbay/PP13, Vidzeme/PP17).

Zems bezdarba un augsts nodarbinātības līmenis ir Tenderē un Vardē, Dānijā. Šìm vietām salīdzinājumā ar Dāniju kopumā ir raksturīgs augsts nodarbinātības lìmenis mazos uzņēmumos (Tendere un Varde/PP15) un "mazs skaits nodarbināto ar augstāko izglìtỉbu" (Varde/PP15).

Iedzīvotāju sastāva īpatnības ir nākamais iesūtīto ziṇu temats par vietas specifiku. Ziņas par iedzīvotāju vecumgrupu sastāva īpatnībām ir šādas: "liels to iedzīvotāju skaits, kas vecāki par 65 gadiem" (Plēne/PP2, Varsinaissuomi/PP4, Kurzeme/PP7, Dienvidigaunija/ PP10, PP11). Daži partneri to formulē tā: "vecumgrupa 50+" veido 54\% no iedzīvotājiem (Ziemeḷ̂rīzlande/PP3, Pagẹegói un Jurbarka/PP9). 
Varsinaissuomi/PP4 partneri no Vāsas, kuriem sociāās spēcināšanas mērḳgrupa ir vecāka gadagājuma personas, ziņas par lielo vecāka gadagājuma cilvēku skaitu precizē ar informāciju, ka daudzi no viņiem dzīvo vieni, ir izolēti, mīt savās mājās neatkarīgi no citiem. "Urbanizācija nav apstājusies. Tas nozīmē, ka mūsu lauku apvidi zaudē jaunos darbspējīgos cilvēkus un te paliek vecāka gadagājuma cilvēki." (Norbotena/PP13, PP14)

Dāņu informators šo procesu raksturo ar frāzi "novecojoši iedzīvotāji” (Tendere un Varde/PP15), informators no Latvijas: "Gados jauno emigrācijas sekas ir novecojusī sabiedrība.” (Vidzeme/PP17)

Cita vietu īpatnība saistībā ar iedzīvotājiem ir iedzīvotāju skaita samazināšanās - "migrācija uz pilsētām un ārzemēm: gados jaunie pamet lauku dzīves vidi” (Kurzeme/PP7, Dienvidigaunija, Veru un Pelvas apriņkis/PP10, Austrumviru un Jervas apriņkis/PP11, Vidzeme/ PP17) vai "emigrācija” (Pagégéi un Jurbarka/PP9), vai "mazs iedzīvotāju skaits un zems iedzìvotāju blīvums" (Dienvidigaunija/PP10, PP11, Vidzeme/PP17).

Imigrācijas vilnis (Ziemeḷ̂rīzlande/PP3, Viduspohjanmā un Pohjanmā/PP5) ir cita nosauktā vietu sociālekonomiskā īpatnība.

Mobilitāte reǵionos ir aktuāls jautājums. Mobilitāte, lietojot sabiedrisko transportu, ir sarežgìta un apgrūtināta. Tas raksturots tā: "Sabiedriskā transporta problēmas lauku apdzīvotās vietās." (Plēne/ PP2, Kurzeme/PP7, Dienvidigaunija/PP10, PP11, Ričivola, Poznaņas regions/PP12, Tendere/PP15, Vidzeme/PP17)

Daudzējādā ziņā labklājīgās Dānijas īpatnība saistībā ar sabiedriskā transporta pieejamību tiek raksturota tā:

Zìmīgs Tenderes ekonomiskās un sociālās ainavas elements ir relatìvi rets vietējais sabiedriskais transports. Lai arī vietējais autocelı tìkls Tenderes iedzīvotājiem ḷauj pārvietoties pa visu regionu, vietējais sabiedriskais transports nepieḷau šo fleksibilitāti. Tenderes iedzīvotāji, lai bùtu mobili, ir vislielākā mērā atkarīgi no personīgās automašinas [..] (Tendere/PP15)

Mobilitātes ierobežojumus lauku dzīves vidē, ja ir nepieciešams lietot sabiedrisko transportu, informators no Plēnes ir iekḷāvis atbildē uz otro jautājumu par faktoriem, kas ietekmē pakalpojumu lietotāju dzīves apstākḷus: 
Galalietotāju grupa (ilgstoši bezdarbnieki - A. S.) bieži vien dzīvo mazos ciematos, kas atrodas tālu no lielākām pašvaldībām. Viñi ir ierobežoti mobilitātē, ja viniem nav personīgās automašinnas, jo bieži tur nav iespējams nokḷut ar autobusu vai vilcienu.

Vēl ir nosauktas šādas vietu ỉpatnību pazìmes:

- augsta deviantās uzvedības koncentrācija (Pageégi un Jurbarka/ PP9);

- augsts nabadzības kultūras demonstrācijas līmenis (Pageégi un Jurbarka/PP9, Dienvidigaunija/PP10, PP11);

- augsta atkarība no sociāliem pabalstiem (Paǵegégi un Jurbarka/ PP9);

- depresīva teritorija, kas reiz bija smagās industrijas centrs Igaunijā, tajā ir izplatītas profesionālās slimības un ir liels skaits krieviski runājošu iedzīvotāju, kuriem nav Igaunijas pilsonības (Dienvidigaunija/PP10, PP11);

- augsti kvalificētu profesionāḷu - ārstu, medmāsu, skolotāju, inženieru un menedžeru - trūkums Norbotenas lēnē Zviedrijā (Norbotena/PP13, PP14, Vidzeme/PP17);

- laukos ir augsts institucionalizācijas līmenis cilvēkiem ar garīgās attīstîbas traucējumiem (Vidzeme/PP17).

\section{Secinājumi par lokālo spēcināšanas tīklu vietu sociālekonomiskām īpatnībām}

Dati rāda, ka, salīdzinot ziņas par astoṇu Baltijas jūras reǵiona valstu SEMPRE projektā pārstāvēto vietu sociālekonomiskām īpatnībām, tajās ir vērojamas gan līdzības, gan atšķirības. Kopīgais ir piederība pie Eiropas Savienības - pie vienas un tās pašas politiski ekonomiskas savienības, kopīgs ir geogrāfiskais reǵions - atrašanās Baltijas jūras krastos, lai gan klimatiskos nosacījumus būtiski ietekmē geogrāfiskā atrašanās vieta. Vispārināti kopīgo un atšḳirīgo var grupēt vairākos tematiskos blokos.

\section{Vispārīgās attīstības īpatnības}

Vēsturiskie notikumi ir ietekmējuši valstu ekonomisko attīstîbu, ètiskos standartus un domāšanas veidu. Zviedrija ir vienīgā no Baltijas jūras reǵiona valstīm, kas nav pieredzējusi tiešu Otrā pasaules kara ietekmi, un tās attīstībā nav notikušas radikālas politiskās un 
ekonomiskās sistēmas pārmaiṇas. Visas pārējās Baltijas jūras reg̣iona valstis ir postītas Otrajā pasaules karā. Dānijai un Somijai ir līdzīga sociālekonomiskā attīstība, bet ir atšķirīga vēstures gaita, geogrāfiskais stāvoklis un klimats. Austrumvācijai un Polijai ir sociālistiskās orientācijas attīstības pieredze, bet tādas nav Šlēsvigas-Holšteinas federālajai zemei kā bijušās Rietumvācijas sastāvdaḷai.

Visām trim Baltijas valstīm ir līdzīga attīstìbas gaita 20. gadsimtā, un tās ir piedzīvojušas radikālas sociālekonomiskas pārmaiņas 90. gadu sākumā. Ekonomikas globalizācija ir pēdējā universālā tendence, kas ietekmē visas pasaules attīstību.

\section{Projektā ietverto vietu ekonomiskās īpatnības}

Partneri ir minējuši tādas ekonomiskās īpatnības kā sezonālā nodarbinātība, kas ir pašsaprotama lauksaimniecībā, mazo un vidējo uzņēmumu dominēšana, kalnrūpniecība kā nodarbinātības pamatjoma Zviedrijas ziemelosos. Nodarbinātības iespēju ierobežojumi ir visbiežāk minētā vietu ekonomiski problemātiskā ìpatnība. Augsts bezdarba lìmenis, vietu ekonomiskā depresija un cilvēku depresija ir izplatìta Baltijas jūras reǵiona valstīs. Augošs imigrantu bezdarba līmenis tiek norādīts Ziemel̦valstīs un Vācijā.

Salīdzinājumam - projekta vietās Dānijā ir ḷoti zems bezdarba līmenis un zems nodarbinātības līmenis privātajā sektorā.

\section{ledzīvotāju struktūras pārmaiņas}

Iedzīvotāju struktūras pārmaiņas ir cits būtisks parādību kopums, kas informē par sociālo procesu tendencēm un apdzivoto vietu īpatnībām.

Vispārinot projektā iesaistīto vietu īpatnības attiecībā uz to iedzīvotājiem, ir jāsecina, ka dominē divas tendences: iedzīvotāju novecošana un depopulācija jeb iedzīvotāju skaita samazināšanās reǵionos. Izplatītākā kopīgā likumsakarība lauku dzìves vidē regionos ir iedzīvotāju novecošana. Tā ir uzrādīta septiṇās no astoṇām Baltijas jūras reǵiona valstīm, Polija šai kontekstā ir vienīgais izņēmums. Otra būtiskākā likumsakarība ir depopulācija jeb iedzìvotāju skaita samazināšanās. Iedzīvotāju skaits laukos samazinās, jo turpinās urbanizācija, proti, liela dạ̦a jauniešu un darbspējīgā vecuma pieaugušo no visām lauku apdzīvotām vietām dodas uz lielākām pilsētām, lai turpinātu izglìtỉbu 
vai meklētu darbu. Cits šo pašu motīvu vadīts migrācijas galamērḳis ir ārzemes, kā tas raksturīgi Baltijas valstīm un Polijai. Skandināvijas valstīs iedzīvotāju skaitu lauku dzīves vidē nedaudz palielina bēglu un imigrantu izmitināšana šajās vietās.

Migrācijas īpatnības projekta vietās ir pretēju virzienu migrācijas plūsmas. Migrācijas kontekstā esošās projektu vietas atspoguḷo šo valstu tipiskās iezīmes.

Sociālās un ekonomiskās labklājības valstis ir galamērḳis imigrācijas plūsmai no konfliktu un attīstības valstīm. Tādēl arī projekta partneriem no Dānijas, Somijas, Vācijas un Zviedrijas sociālās spēcināšanas izvēle ir tie profesionālị, kas strādā ar bēgḷiem un imigrantiem, kā arī paši bēg̣̦i un imigranti. Kolēge no Dānijas šai sakarā zināja teikt, ka dāṇu pārvaldības institūcijas ir smagi strādājušas, lai racionāli vadītu un ierobežotu imigrācijas procesu.

Postpadomju Baltijas valstîs pēc neatkarības atjaunošanas liela daļa iedzìvotāju atstāja savu valsti. Plašā izbraucēju plūsma veidojās galvenokārt sociālo un ekonomisko iemeslu dēl, tikai kāda neliela dą̣a izbrauca no valsts, lai iegūtu izglìtỉbu un/vai meklētu dažādus piedzīvojumus.

\section{Infrastruktūras īpatnības}

Infrastruktūras stāvoklis un kvalitāte Baltijas jūras reg̣iona valstīs ir atšķirīgi. Piemēram, Latvijā lauku reǵionos daudzviet izzūd izglìīibas, veselíbas aprūpes, pasta, banku, veikalu pakalpojumu pieejamíba. Cēloṇi tam ir racionālas un uz kopīgo sociālo labklājību orientētas pārvaldības trūkums, kas rezultējas finanšu nepietiekamībā sociāliem mērḳiem. Norbotenas lēnē Zviedrijā trūkst profesionāḷu medicīnas un sociālajā jomā.

Atsevišḳi izceḷams ir tāds infrastruktūras un sociālo pakalpojumu elements kā sabiedriskā transporta pakalpojumi un autoceḷu stāvoklis. Lauku dzīves vidē Latvijā mazinās sabiedriskā transporta pieejamība laukos un autocel̦u stāvoklis daudzviet ir slikts.

Projekta vietās Dānijā autoceḷu tìkls un kvalitāte tiek raksturota kā laba, bet sabiedriskā transporta pieejamība tur ir tik ierobežota, ka mobilitāte bez personiskās automašīnas ir ḷoti apgrūtināta, gandrīz vai neiespējama. Līdzīga situācija, kā liecina šo vietu pārstāvji, ir Plēnē un Ziemeḷfrīzlandē Vācijā. 


\subsection{Sociālo pakalpojumu galalietotāju dzīves apstākḷu raksturojums}

Lakoniskā formā sniegtā partneru informācija par faktoriem, kas ietekmē sociālo pakalpojumu galalietotāju dzīves apstākḷus, veido samērā garu sarakstu. Tiek pieminēti šãdi faktori:

- pakalpojumi ir izkliedēti pa dažādiem birojiem, un ir dažādi pakalpojumu sniedzēji. To sasniegšanai nepieciešams laiks un naudas investīcijas cel̦a izdevumiem (Ditmāršene/PP1);

- netiek sniegta neatliekamā psihologiskā palīdzība Ditmāršenes pierobežas iedzīvotājiem (Ditmāršene/PP1);

- sabiedriskā transporta trūkums, mobilitātes apgrūtinājums (Plēne/PP2, Ziemel̦frīzlande/PP3, Kurzeme/PP7);

- bērnu aprūpes trūkums vecāku darba laikā vai arī augstas izmaksas par bērnu pieskatīšanu darbadienas laikā (Plēne/PP2);

- grūti dabūt darbu bezdarbniekiem, īpaši ilglaicīgiem bezdarbniekiem, regiionā dominējošos mazos un vidējos uzṇēmumos (Plēne/PP2);

- mazs subsidēto darbavietu skaits personām ar invaliditāti (Kurzeme/PP7);

- sociālā uzṇēmējdarbība ir nepietiekami attīstīta (Kurzeme/ PP7);

- pārāk ilgs ir bēgḷa statusa iegūšanas laiks (Ziemeḷfrīzlande/ PP3);

- mājokḷu trūkums (Ziemel̦frīzlande/PP3);

- lieli pārvaramie attālumi laukos (Varsinaissuomi/PP4, Ričivola/PP12);

- demogrāfiskām pārmaiṇām atbilstošu pakalpojumu trūkums, jo pakalpojumi tiek centralizēti un datorizēti un vecāka gadagājuma personām laukos nav piemēroti (Varsinaissuomi /PP4);

- skaudrs klimats ziemā (Varsinaissuomi/PP4);

- rasisms un stigmatizācija (Viduspohjanmā un Pohjanmā/PP5);

- nepietiekamas valodas prasmes kavē iegūt izglìtību un ir šķērslis integrācijai sabiedrībā (Viduspohjanmā un Pohjanmā/PP5, Norbotena (Sunderbay)/PP13, Tendere, Varde/PP15);

- finansiāli ierobežojumi un finanšu pratības deficīts personām ar invaliditāti (Kurzeme/PP7);

- vientulības diskomforts personām ar invaliditāti un vecāka gadagājuma personām (Kurzeme/PP7, Varsinaissuomi/PP4); 
- nedraudzīga līdzcilvēku attieksme pret personām ar invaliditāti (Kurzeme/PP7);

- izglìīibas deficīts, trūkst profesionālās un vidējās izglītības atkarīgām personām un viena vecāka gimenes pieaugušai personai (Pagégéi un Jurbarka/PP9);

- sociālo prasmju deficīts (Pageēéi un Jurbarka/PP9);

- neprasme tikt galā ar dažādām dzives situācijām (Pageégi un Jurbarka/PP9);

- stigmatizācija par novirzi no tradicionālās ǵimenes modẹ̦a (Pagégéi un Jurbarka/PP9);

- pēc rehabilitācijas vielatkarīgās personas ar grūtībām spēj atgriezties sabiedrībā (Paḡégi un Jurbarka/PP9);

- alkoholisms (Dienvidigaunija, Veru un Pelvas apriņķis/PP10, Austrumviru un Jervas apriņkis/PP11);

- gimenes ir atšḳirtas, jo darbu atrast var vien kaut kur tālumā (Dienvidigaunija, Veru un Pelvas apriņ̧̧is/PP10, Austrumviru un Jervas apriņ̧is/PP11);

- dažās dzīvesvietās nav veikalu (Dienvidigaunija, Veru un Pelvas apriņkis/PP10, Austrumviru un Jervas apriņķis/ PP11);

- vidējie ienākumi Austrumigaunijā ir zemāki par valstī vidējiem ienākumiem (Dienvidigaunija, Veru un Pelvas apriņ̧̧is/ PP10, Austrumviru un Jervas apriņkis/PP11);

- bezcerība, apātija, motivācijas trūkums (Paǵēǵi un Jurbarka/ PP9, Dienvidigaunija, Veru un Pelvas apriņkis/PP10, Austrumviru un Jervas apriņkis/PP11);

- HIV/AIDS izplatība (Austrumviru un Jervas apriņ̧is/PP11);

- sociālā dezintegrācija pēc etniskās piederības (Austrumviru un Jervas apriņkis/PP11);

- kopīgu tikšanās un pulcēšanās vietu trūkums a) jauniešiem (Ričivola, Poznaņas reǵions/PP12), b) pamatiedzīvotājiem ar imigrantiem (Norbotena, Sunderbay/PP13);

- jaunatnes domas un viedokḷi netiek ņemti vērā, tos neuzskata par nopietniem (Ričivola, Poznaņas regions/PP12);

- imigrantu segregācija un diskriminācija (Norbotena, Sunderbay/PP13, Tendere, Varde/PP15);

- slikti dzives apstākḷi - trūcīgi mājokḷi, kuros trūkst pamatērtības - tekošs ūdens, sanitārais mezgls (Vidzeme/PP17). 
Secinājumi par sociālo pakalpojumu lietotāju dzīves apstākḷiem

Fakts, ka pakalpojumu lietotāju kategorijas ir daudzveidīgas un ka dažkārt viena kategorija, piemēram, bezdarbnieki, tiek sazarota pēc kādas precizējošas pazimes, ir iemesls tam, ka dzìves apstākḷus raksturojošo pazīmju skaits ir liels. To ir ap 30.

Sociālo pakalpojumu sniedzēju nosauktos faktorus, kas ietekmē pakalpojumu lietotāju dzīves apstākḷus, var apvienot vairākās nozīmīgās grupās. Ir konstatējama tieša sakarība starp iepriekš uzrādītām vietu īpatnībām un sociālo pakalpojumu lietotāju dzives apstākḷus raksturojošām īpašībām. Tiek norādīti šādi faktori, kas ietekmē sociālo pakalpojumu lietotāju dzīves apstākḷus: ekonomiskie faktori, mobilitātes ierobežojumi, migrācija, iedzīvotāju novecošana, sabiedrības dezintegrācija, negatīva sabiedrības attieksme, psiholoğiskas problēmas un pakalpojumu sniedzēju darba organizatoriskās nepilnības. Ieskatam apkopota informācija par šiem faktoriem.

Ekonomiskie faktori. Bezdarbs bieži tiek minēts kā faktors, kas dzīvi sarežg̀ì visiem, kurus tas skāris, vai tie būtu dažādu vecumgrupu vietējie iedzīvotāji, bēg̣̣i un imigranti vai personas ar invaliditāti.

Personām ar invaliditāti Latvijā dzives apstākḷus apgrūtina zemās invaliditātes pensijas.

Telpiski ierobežojumi ir ekonomisko faktoru apakšgrupa. Telpu trūkums tikšanās pasākumiem, ko piemin poḷu un Ziemel̦zviedrijas partneri, varētu būt daḷēji ekonomiski, daḷēji organizatoriski determinēts. Mājokḷu trūkums imigrantu izmitināšanai Ziemeḷfrīzlandē ir cits šai vietai raksturīgs ekonomiskā faktora paveids.

Mobilitātes ierobežojumi laukos ir sāpīga aktualitāte, jo sabiedriskais transports ir pieejams reti vai tikpat kā nepieejams. Dažās apdzīvotās vietās tas ir pārstājis kursēt vispār, jo pārvadātājiem pel̦nas vietā ir zaudējumi. Dānijā un Vācijā, kur autoceḷu tīkls un kvalitāte ir nevainojami, sabiedriskais transports nekursē vai kursē tā, ka sociālie pakalpojumi un darbavieta ir nepieejami, ja nav savas automašīnas. Latvijā ir ne vien sabiedriskā transporta aizvien ierobežotāka pieejamība reǵionos, bet arī kritisks autocel̦u un zemes ceḷu stāvoklis daudzās vietās reǵionos.

Tālās distances reǵionos ir cits faktors, kas apgrūtina mobilitāti un ietekmē sabiedriskā transporta pakalpojumu pieejamību. To piemin somu un polı partneri. 
Migrācija uz pilsētām un ārzemēm, kas ir izplatīta jauniešu vecumā un ekonomiski aktīvu cilvēku vidū, maina iedzīvotāju vecumstruktūru, pasliktina vietu ekonomisko stāvokli, samazina sociālo pakalpojumu piedāvājumu lauku apdzīvotās vietās. Urbanizācijas tendence ietekmē iedzīvotāju vecuma sastāvu visās Baltijas jūras reǵiona valstīs, to papildus iespaido jauniešu un ekonomiski aktīvo iedzivotāju emigrācija uz ārzemēm, kas ir izplatīta parādība Igaunijā, Latvijā un Lietuvā.

Iedzivotāju novecošana lauku dzīves vidē, kas izpaužas kā vecāka gadagājuma iedzīvotāju īpatsvara palielināšanās, ir sekas iepriekš minētai gados jauno cilvēku migrācijai no laukiem uz pilsētām un/vai ārzemēm.

Sabiedrības dezintegrācija pèc piederības pie citas rases un etnosa, proti, pie visāda veida imigrantiem, tiek dokumentēta bieži. Igaunijā tā izpaužas attieksmē pret "krievu valodas nesējiem", Dānijā, Somijā, Vācijā un Zviedrijā - pret imigrantiem no akūtu (Sīrija) un hronisku vardarbīgu konfliktu valstīm (Afganistāna, Irāka), kur ekonomika ir sagrauta un normāli dzīves apstākḷi ir iznīcināti.

Negatìvā sabiedrības attieksme pret citādību savā ciltī un ienācējiem no ārienes ir biologiski un tradīciju determinēta parādība. Igaunijā, Dānijā, Somijā, Vācijā un Zviedrijā tiek norādīts uz negatīvu attieksmi pret jauniem un seniem imigrantiem vietējās valodas nezināšanas un kulturālo atšksirību dẹḷ.

Negatīvā sabiedrības attieksme pret svešiniekiem ir sensena biologiski, psihologiski un tradīcijās nostiprinātu uzvedības ieradumu determinēta reakcija. Tã ir saistìta ar drošîbu, ar izvairīšanos no riska tikt apdraudētam. Tāda attieksme ir pašsaglabāšanās instinkta izpausme. Šì negatīiā attieksme pret citādo un nepazīstamo ir viens no sabiedrības dezintegrācijas vektoriem (Simmel, 1992).

Cits sabiedrības dezintegrācijas vektors ir ètiski attaisnojamā negatīvā attieksme pret devianto uzvedību - kaitīgām atkarībām, vardarbību, noziedzību. Partneru biežāk minētais deviantās uzvedības paveids, kas raksturo un ietekmē dzìves apstākḷus, ir vielatkarības. Alkoholisms un narkomānija ir igauṇu, latviešu un lietuviešu partneru nosauktais faktors, kas negatīvi ietekmē sociālo pakalpojumu lietotāju dzīvi. Negatīva sabiedrības attieksme pret personām ar destruktīvu un deviantu uzvedību ir pozitīvi vērtējama kā garīgi un morāli veselīgas sabiedrības daḷas slavējama reakcija.

Psihologiskas problēmas var nopietni ietekmēt cilvēku iekšèjo komfortu un dzīves izjūtu. Sociālo pakalpojumu lietotājiem 
psihologiskas problēmas ir dziḷas un plaši izplatītas. Igauņu, latviešu un lietuviešu partneri min tādus psihologiskus stāvokḷus kā bezcerība, apātija, motivācijas trūkums, sociālo prasmju deficīts, neprasme tikt galā ar dažādām dzìves situācijām. Vientulība kā diskomforta izjūta tiek pieminēta saistībā ar vecāka gadagājuma personām Somijā un personām ar invaliditāti Latvijā.

Aptaujā vācu partneri norāda uz pakalpojumu sniedzēju darba organizatoriskām nepilnībām Ditmāršenē. Tās kā nopietnu šḳērsli uzrāda arī Latvijas, Somijas un Vācijas sociālās labklājības eksperti padzilinātā aptaujā par barjerām un šḳērṣ̌̆liem sociālo pakalpojumu sniegšanā.

\subsection{Barjeras un šķēršşli sociālo pakalpojumu sniedzēju darbā}

Par barjerām un šḳēršliliem, ar ko nākas sastapties, sniedzot sociālos pakalpojumus, tika jautāts sociālo pakalpojumu organizāciju profesionāliem formalizētajā aptaujā. Atbildes uz jautājumiem par barjerām un šḳēešḷiem formāli netika ierobežotas. Tika piel̦autas visu veidu barjeras un šķēršlli, kurus profesionāļi varēja darìt zināmus, izvērtējot savu reālo darbu, pārdomājot, kas vinu darbā neapmierina un būtu maināms. Par barjerām un šḳēršliem tika nosaukti ekonomiski, juridiski, organizatoriski, sociāli un kulturāli apstākḷi.

Nosaukto barjeru un šķērš̌lu uzskaitījums ir garš. Lai daudzveidīgā partneru sniegtā informācija saglabātu satura bagātîbu un izteiksmes stilu, tā tiek sniegta maksimāli pietuvināti partneru formulējumiem. Izteikumu secība veidota, ievērojot partneru kārtas numuru. Tad, kad cits partneris izsakās par to pašu, kas ticis pieminēts iepriekš, partnera vieta un norāde uz kārtas numuru tiek pievienota tam apstāklim, kas atkārtojas. Barjeru un šķēešş̧u uzskaitījuma analīzes rezultāts to tipologijas formā tiek sniegts šīs teksta sadal̦as nobeigumā.

Partneru formulējumos barjeras un šķērṣ̌li veido turpmāk piedāvāto sarakstu.

Fokusēšanās uz esošiem pakalpojumiem un nevēlēšanās domāt par pārmaiņām (Ditmāršene/PP1).

Publisko finanšu samazināšanas izraisīts spiediens uz pakalpojumu sniegšanu (Ditmāršene/PP1).

Tradicionāls lomu modelis (Plēne/PP2). 
Motivācijas trūkums pakalpojumu saṇēmēju vidū (Plēne/PP2, Kurzeme/PP7, Paǵēgi un Jurbarka/PP9).

Nevēlēšanās doties uz citām vietām darba meklējumos, jo darbojas ieraduma spēks un bailes atstāt ierasto lauku vidi (Plēne/PP2).

Bēgḷu un imigrantu izvairīgās atbildes par vēlamo dzīvesvietu ir šḳērslis viṇu ātrākai integrācijai (Ziemel̦frīzlande/PP3).

Pakalpojumu sniedzēju lietotāju valodas nezināšana (Ziemeḷfrīzlande/ PP3). Imigrantu nepietiekamas vietējās valodas zināšanas (Tendere, Varde/PP15).

Kulturālas atšķirības ir nesaprašanās cēlonis par relig̣iskām un dzimumu lomām (Ziemeḷfrīzlande/PP3).

Bēgḷiem ir kara izraisìtās psihologiskās traumas (Ziemeḷfrīzlande/PP3). Grūtības sameklēt un sasniegt reālos vai potenciālos visievainojamākos pakalpojumu sañēmējus (Varsinaissuomi/PP4, Kurzeme/PP7). Pāreja no speciāliem bēg̣̣u integrācijas pakalpojumiem uz pakalpojumu sniegšanu bēgliem pēc vispārējiem noteikumiem ir kritiska bēgḷu spēcināšanai (Viduspohjanmā/PP5).

Zems pakalpojumu lietotāju izglìtības līmenis (Pageegéi un Jurbarka/ PP9).

Sociālo prasmju un situāciju risināšanas prasmju trūkums pakalpojumu saņēmējiem (Pagéẹi un Jurbarka/PP9).

Speciālo darba prasmju iztrūkums sociālo pakalpojumu sniedzējiem, nepietiekama specializācija personālam sociālo pakalpojumu organizācijās (Pageégi un Jurbarka/PP9, Dienvidigaunija, Austrumviru un Jervas aprinkisis/PP11).

Nepietiekama komunikācija starp dažādu municipalitāšu sociālo pakalpojumu sniedzējiem (Dienvidigaunija, Veru un Pelvas apriņķis/PP10, Austrumviru un Jervas apriņkis/PP11).

Sociālo pakalpojumu sniedzēju un san̦ēmēju atškirīigie uzskati par vajadzībām un palīdzības formām (Dienvidigaunija, Veru un Pelvas aprinkisis/PP10, Austrumviru un Jervas aprinkisis/PP11).

Būtu vajadzīga "daudzfunkcionāla" pakalpojumu sniedzēju komanda, kurā strādātu psihologs, finanšu speciālists un pastorāls padomdevējs (Dienvidigaunija, Austrumviru un Jervas apriṇkis/PP11). Vecāka gadagājuma personām ir nepieciešami datorpratîbas apmācību pakalpojumi, jo daudzi pakalpojumi pieejami tikai ar interneta starpniecību (Dienvidigaunija, Austrumviru un Jervas apriņkis/ PP11). 
Draudzīgas sadzivošanas tradīciju trūkums. Seniori ir vientuli, vienlaikus gimenēm ar bērniem ir vajadzīga vecvecāku palīdzība (Dienvidigaunija, Austrumviru un Jervas apriņkis/PP11).

Informācijas deficìts (Dienvidigaunija, Austrumviru un Jervas apriṇkis/PP11).

Cilvēkiem bez pilsonības ir nepieciešamas konsultācijas, jo viṇi nav integrēti, ir neinformēti par darba tirgu, par sociāliem pabalstiem, nacionālās valodas mācǐšanās iespējām un pilsoniskās sabiedrības mehānismiem (Dienvidigaunija, Austrumviru un Jervas apriṇkis/ PP11).

Telpu trūkums, kur pulcēties jauniešiem vai kur pulcēties iezemiešiem ar imigrantiem (Ričivola, Poznaņas regions/PP12, Norbotena, Sunderbay/PP13).

Starppaaudžu konflikts un nesaprašanās, attieksme "mēs darām jums" tā vietā, lai teiktu "mēs darām kopā ar jums" neveicina jauniešu līdzdalibu (Ričivola, Poznaņas reğions/PP12).

Pēc kursu "Zviedru valoda imigrantiem” pabeigšanas un 24 mēnešu individuālās integrācijas plāna daudzi imigranti paliek par bezdarbniekiem. Sabiedrība vinus maz atbalsta (Norbotena, Sunderbay/PP13).

Segregācijas problēmas starp iedzimtajiem un imigrantiem (Norbotena, Sunderbay/PP13).

Grūti atrast tos jauniešus, kuriem ir zems izglìtïbas līmenis un nav darba un kuri riskē kḷūt par ilgtermiņa bezdarbniekiem. Ir nepieciešami jauni instrumenti, kā viniem palīdzēt atrast personiskus mērķus un sniegt atbilstošu izglitību (Norbotena, Companion/PP14). Vidzemes partneris nosauc garu barjeru un šķēešlı uzskaitijumu, kas nodēvēts par ierobežojumu kompleksu darbā ar jauniešiem, kam nav izglitības, prasmju un darba. Ja garo uzskatījumu reducē uz būtiskāko, tad būtiskākais ir ierobežota sociālo pakalpojumu un sabiedriskā transporta pieejamība regionos, ierobežotas finanses, nepietiekama komunikācija un nepietiekama darbu koordinācija starp dažādām institūcijām. Sociālo pakalpojumu sniedzējiem trūkst pieredzes darbā ar šādas kategorijas jauniešiem, lokālās jauniešu organizācijas strādā vienīgi ar līderiem, vecāku iesaistī̌sanos kavē laika un finanšu trūkums (Vidzeme/PP17).

Sarežgìita juridiskā infrastruktūra, kā koordinēt dažādu pakalpojumu veidus (Tendere, Varde/PP15). 
Apjomīga dokumentācija, "papīra darbu" daudzums, ko liek darìt sarežg̀itā juridiskā infrastruktūra, ir tik liels, ka bēgḷ vidū izraisa sajūtu, ka tiek ierobežota vinu iesaistīšanās sabiedrībā. Tas ietekmē viṇu spēcināšanu tādējādi, ka tā pārvēršas par savu pretstatu - viṇu vājināšanu (Tendere, Varde/PP15).

Tāds ir barjeru un šķēršlu apkopots uzskaitījums pēc partneru sniegtajiem datiem.

Pirms tipologizēt barjeras un šḳēršlus un izdarìt secinājumus par barjerām un šḳēršliem sociālo pakalpojumu sniegšanā, te apkopotiem visu partneru datiem ir pievienojama padziḷināta informācija par barjerām un šḳērṣ̌liem sociālo pakalpojumu organizāciju darbā. Papildinformāciju ir snieguši Latvijas, Somijas un Vācijas eksperti sociālo pakalpojumu sfērā.

\section{Padziļināta Latvijas, Somijas un Vācijas ekspertu informācija par barjerām un škēršliem sociālo pakalpojumu organizāciju darbā}

Barjeru un šḳēršlu padziḷinātai apzināšanai tika izvirzīts moto: apzināt savas vājās puses ir ceḷšs, kā tās pārvarēt un ḳ̣ùt stiprākiem.

Metodologija. Lai iegūtu padziḷinātu informāciju par barjerām un šḳēeš̌liem sociālo pakalpojumu organizāciju darbā, 2017. gada jūnijā un jūlijā tika veikta lokālo spēcināšanas tīklu ekspertu aptauja Latvijā, Somijā un Vācijā. Aptaujas instruments ir dal̦ēji strukturēta anketa. Aptaujas mērḳis - iegūt padziḷinātu informāciju par barjerām un šķēršlliem sociālo pakalpojumu organizāciju darbā, kā arī verificēt 2016. gada pirmajā pusē partneru sniegto informāciju par barjerām un šḳēršliem organizāciju darbā un uzzināt par pārmain̄ām organizāciju darbā šai laikposmā. Latvija, Somija un Vācija tika izvēètes, kombinējot racionālu izvēli un nejaušības principu. Racionalitāte tika likta lietā, sadalot visas astoṇas ES Baltijas jūras regiona valstis trīs atškirīgās valstu grupās - Baltijas valstis, Skandināvijas valstis un Centrāleiropas valstis. Pēc tam tika izlozēta viena valsts no katras grupas. Kopumā tika veiktas 16 ekspertu aptaujas, piecas - Latvijā, četras - Somijā, septiṇas - Vācijā.

Šoreiz daḷēji strukturētās anketas plāns ir izvērstāks un tajā tiek piedāvāts faktoru kopums, kas ietekmē būtiskāko sociālo pakalpojumu organizāciju darbu un kas ir gan noskaidrojies iepriekšējā aptaujā, gan ticis fiksēts citos avotos praksē un teorijā. Respondentiem ir dota iespēja brīvi papildināt savas atbildes. 
Informācijas analīzē barjeras un šḳēršli tiek sadalīti divās lielās grupās. Tās ir klasificētas kā materiālās un nemateriālās barjeras un šķēršși. Katrai grupai ir pakārtotas vairākas apakšgrupas. Tiek definēta barjeru un šķērṣ̌ı specifika, nosakot, ka barjeras ir ar cilvēku saistīti subjektīvi iekšèjie faktori, turpretim šḳērṣ̌i ir lielā mērā objektīvi ārējie faktori. Ir izveidots šāds darbu ietekmējošo faktoru sadalijums:

1. Materiālie šḳēršlı̆i.

1.1. Finansējums sociālo pakalpojumu sniegšanai.

1.2. Sociālo pakalpojumu sniedzēju zemais atalgojums.

1.3. Darba telpu stāvoklis.

1.4. Sabiedriskā transporta pieejamība.

2. Nemateriālās barjeras un šḳērṣ̌li.

2.1. Darbības juridiskā regulācija.

2.2. Barjeras un šḳērṣ̌li, kas saistīti ar personālu un tā darba apstākḷiem.

2.2.1. Profesionāla personāla pieejamība.

2.2.2. Personāla specializācija.

2.2.3. Birokrātiski šḳēršli (pārmērīgs dokumentācijas producēšanas daudzums).

2.2.4. Psihologiskas barjeras.

2.2.5. Societālas barjeras.

2.2.6. Horizontālās un vertikālās komunikācijas kvalitāte un darbu koordinācijas kvalitāte.

2.2.7. Svešvalodu zināšanu deficīts.

2.2.8. Cilvēciskais faktors un tā kvalitāte varas/pārvaldības struktūrās.

2.2.9. Citas barjeras un šķēršlli.

\section{Empīriskās informācijas analīzes rezultāti}

2016. un 2017. gadā veiktajās aptaujās pārmaiņas barjeru un šḳēršlu apzināšanā nav konstatētas.

No jauna iegūtā informācija pārsvarā ir saistīta ar personālu un nemateriāliem faktoriem - psihologiskām barjerām, komunikāciju, darba koordināciju, sabiedrības attieksmi pret sociālo pakalpojumu lietotājiem. Taču tiek norādīts arī uz finansējuma nepietiekamību. 


\section{Finansējuma nepietiekamība pakalpojumu sniegšanai un personāla atalgošanai}

Par materiāliem šķērṣ̌liem sociālo pakalpojumu sniedzēju darbā tiek liecināts galvenokārt divos aspektos. Viens no tiem ir vajadzība palielināt finansējumu vietējās valodas mācībām bēgḷiem un imigrantiem, lai viņi varētu sekmīgāk integrēties iecel̦ošanas zemes sabiedrībā. Otrs ir personāla zemais atalgojuma līmenis sociālo pakalpojumu un sociālās aprūpes iestādēs. Fiziski un psihologiski smagā darba prestižu stipri pazemina zemais atalgojums. Tādēḷ ir personāla deficìts. Būtisks personāla deficita iemesls ir zemais atalgojums par šo psihologiski saspringto darbu, kas personāla deficīta un/vai darba organizācijas dẹl reizēm veicams pārslodzes režīmā. Mana pieredze mācību darbā ar sociālā darba studentiem liecina, ka dal̦a jauniešu, kas apguvuši šo specialitāti, nevēlas strādāt šajā, vinuprāt, nepievilcīgajā jomā. Par nepievilcīgu tiek uzskatīts atalgojuma līmenis, darba apstākḷi un bieži sastopamās psiholog̣iski un sociāli smagās situācijas, kurās atrodas pakalpojumu lietotāji. Personālam tas izraisa distresu un hiperstresu.

Pakalpojumu sniedzēju darba nozīmes nenovērtēšana, kas izpaužas zemajā atalgojumā, izraisa viņos netaisnības izjūtu un pazemojuma jūtas. To, ka pacietības mērs ir pilns un klusēšana ir jāpārtrauc, liecināja Latvijas sociālās aprūpes centru darbinieku arodbiedrības paziṇojums, ka, protestējot pret zemo atalgojumu, kas sociāliem aprūpētājiem Latvijā ir valstī noteiktās minimālās algas apjomā (2018. gadā tās bruto apjoms ir 430,00 eiro mēnesī), vini 2018. gada 28. septembrī rìko astoņu stundu bada streiku. Bada streiks ir noticis, un tika sāktas sarunas ar Labklājỉbas ministriju par algu palielināšanu. Ir neapšaubāma netaisnība par šo fiziski, psiholoğiski un morāli smago darbu saņemt atalgojumu, par kuru izdzìvot nav iespējams.

Tiesību normatīvā regulācija var būt un ir šķērslis sociālo pakalpojumu sniegšanā tajos gadỉjumos, kad likumu normas ir pretrunīgas, nav harmonizēti dažādu līmeṇu dokumenti, kā arī tad, kad notiek likumu reformēšana, tiek veikti grozijjumi likumos vai stājas spēkā jauna likumdošana. Somijā likumdošanas reforma sociālajā jomā ir aktualitāte 2017. gada aptaujas laikā. Ja maina likumdošanu, kas saistīta ar sociālo palīdzību, tas vismaz uz laiku apgrūtina sociālo pakalpojumu sniedzēju darbu. 


\section{Profesionāla personāla deficīts sociālo pakalpojumu organizācijās}

Par profesionāla personāla nepietiekamo skaitu, tā atrašanas un piesaistī̌sanas grūtībām lauku vidē reǵionos informē Latvijas un Vācijas partneri. Abās valstīs reǵionos ir grūti piesaistìt jaunos speciālistus. Pašreizējais personāls tuvojas pensionēšanās vecumam, darbinieku skaits sociālo pakalpojumu jomā sarūk. "Mums jāpadara sociālais darbs atraktīvāks jauniem cilvēkiem," - atzīst sociālo pakalpojumu sniedzēji no Vācijas.

Viens no personāla deficīta iemesliem ir zemais atalgojums par šo psihologiski saspringto darbu, kas personāla deficìta un/vai darba organizācijas dēḷ reizēm veicams pārslodzes režìmā.

Psihologiskās spēcināšanas vajadzība tiek apliecināta kā nepieciešamība gan personālam, gan pakalpojumu lietotājiem. To uzsver Latvijas un Vācijas partneri. Latvijas pārstāvji vairākkārt apliecina psihologa kā patstāvīga organizācijas darbinieka vajadzību. Vācijas eksperti izsaka vēlmi savās problēmsituācijās saņemt palīdzību no organizācijas vadỉbas, savukārt ilgstošiem bezdarbniekiem ir akūti nepieciešams "stiprināt pamatemocijas un pašcieņu".

Personāla specializācija darbam ar noteiktu sociālo pakalpojumu lietotāju kategorijām ir apzināta nepieciešamība Latvijā un Vācijā, kur ir konstatēts, ka personālam trūkst zināšanu gan par mūsdienu idejām un teorijām, kas saistītas ar noteiktas kategorijas pakalpojumu lietotājiem, gan par praktisku rīcību, kontaktējoties ar noteiktas kategorijas pakalpojumu lietotājiem, piemēram, ar personām, kurām ir garīgās attīstības traucējumi un psihiski traucējumi. Personāla specializācija ir nepieciešama arī darbā ar tiem jauniešiem, kuriem ir zems izglìtības lìmenis, nav prasmju un nav darba.

Birokrātiskie šķēeršlı, kas saistīti ar izvērstas dokumentācijas gatavošanu, pasliktina darbu un sociālo pakalpojumu lietotāju stāvokli, jo kontaktēšanās laiks, kas atvēlēts pakalpojumu lietotājiem, samazinās. "Mēs permanenti esam pārslogoti ar sociālo pabalstu maksājumiem un papīru kalniem," - liecina sociālo pakalpojumu sniedzēji no Latvijas. Taču tādas pašas sūdzības izskanējušas arì Dānijā.

Societālas barjeras. Par societālām barjerām tiek definētas tās barjeras, kas attiecas uz sabiedrību kopumā vai šajā gadījumā uz lielu sabiedrības daḷu. Te iztirzātā temata kontekstā tā tiek apzīmēta negatīva attieksme pret dažāda veida atšķirībām un novirzēm no sabiedrībā pieṇemtām uzvedības normām. Negatīva attieksme pret atšḳirīibām un 
novirzēm izpaužas kā stigmatizācija, marginalizācija, diskriminācija, neiecietība, izslēgšana jeb atstumšana, kas var būt vērsta gan pret savas zemes citādajiem, gan pret svešzemniekiem: "Societāla atmosfēra pret migrantiem ir skaudra, un cilvēkiem (pat pakalpojumu sniedzējiem) ir sava pārliecība, kas nesaskan ar cilvēktiesībām” (Somija); “[..] naidīgums pret ārzemniekiem” (Vācija); “[..] stigmatizācija ir liela sabiedrības problēma (piemēram, viena vecāka gimenes tiek diskriminētas pat vietējo politiķu publiskās runās” (Vācija); “[..] sabiedrībā ir plaši izplatìta neiecietîba un negatīva attieksme pret disfunkcionālām gimenēm un vinuu bērniem, [..] nabadzīgo ğimeņu materiāla atbalstī̌sana izraisa skaudību citos kopienas pārstāvjos, [..] cilvēki ir pret izmaksām un izdevumiem citu labā, vai tie būtu cilvēki ar invaliditāti, nabadzīgie, trūcīgie vai vielatkarīgie" (Latvija).

\section{Barjeras un šḳēršlı komunikācijā}

Daudzās atbildēs plaši izvērstais temats saistīts ar komunikāciju. Komunikācija cieši saslēdzas ar jau minēto psihologisko problemātiku, un abas rada daudz sarežǵijumu ikdienā un darbā. Tā kā komunikācijai ir divas asis - horizontālā un vertikālā, tad tās izraisìto iespējamo un reālo sarežğijumu lauks ir plašs. Horizontāli tā noris ar tā paša līmeņa kontaktpersonām. Vertikāli komunikācija noris padotībaspakḷautības skalā. Vertikāli komunikācija noris vienā organizācijā ar vadošo personālu, tāda tā var būt starp dažāda līmeṇa organizācijām. Un šì asimetriskā varas pozīcija gribot negribot izpaužas komunikācijā ar sociālo pakalpojumu lietotāiiem.

Par komunikāciju ar sociālo pakalpojumu lietotājiem tiek pausts, ka vecāka gadagājuma personas un ilgtermiṇa bezdarbniekus ir grūti sasniegt un grūti sākt komunicēt ar viņiem. Ilgtermiņa bezdarbnieku dzìve nabadzībā un sociālā izolācijā rada kauna jūtas, un viṇi izvairās no komunikācijas ar citiem.

Ar bēgḷiem un imigrantiem komunikācija ir apgrūtināta valodas barjeras dēlı.

Komunikāciju var apgrūtināt nepietiekams personāla skaits, specializēta personāla aiziešana no darba, laika ierobežojumi, kādi ārēji šķēeršlıi un arī gan personāla, gan pakalpojumu lietotāju iekšejēās barjeras.

Savu ìpatnību komunikācijā var radìt sociālo pakalpojumu saṇēmēju emocionālie stāvokḷi un ieradumi. Latvijas sociālo pakalpojumu sniedzēji informē, ka dažkārt pakalpojumu lietotāji mēdz izgāzt savas 
dusmas uz sociālo dienestu personālu, mēdz būt neiecietīgi vai arī šantažè sociālo pakalpojumu sniedzējus.

\section{Komunikācija starp institūcijām un darba aktivitāšu koordinācija}

Komunikācija un rīcības koordinācija ir plašs nepieciešamo uzlabojumu un iespēju lauks. Tas ir jo cieši saistīts ar komunikācijas un informācijas aprites pilnveidošanu. Par nepilnībām komunikācijas plūsmās un darbību koordinācijā žēlojas Latvijas, Somijas un Vācijas pārstāvji. Somu partneri norāda uz "spēcīgu koordinācijas trūkumu starp vienas nozares aktoriem", ko profesionāli mēǵina pārvarēt, veidojot tîklošanos. "Trūkst darba koordinācijas starp sociāliem dienestiem un pakalpojumu sniedzējiem pieaugušo izglìtības un nodarbinātības jomā," liecina cits somu partneris. "Aktivitāšu koordinācijas deficītu” atzīst vēl trešais somu pārstāvis, piebilstot, ka tiek smagi strādāts, lai to pārvarētu. "Aktivitāšu koordinācijas deficītu" un vēlmi, lai būtu "labāka komunikācija starp atbildīgiem dienestiem, sabiedrības pārvaldības institūcijām un pakalpojumu sniedzējiem" vācu partneri piemin saistībā ar problēmu risināšanu darbā ar bēgḷiem. Nodarbinātības centriem trūkstot oficiālas informācijas par bēglu nodarbināšanas iespējām, integrēšanas kursiem, to uzdevumiem un mērḳiem.

Informācijas un koordinācijas trūkumu darbā ar problemātiskajiem jauniešiem, kuriem nav izglìīibas, darba un prasmju, uzsver Latvijas partneri no Vidzemes: "[..] informācijas un aktivitāšu koordinācijas trūkums starp skolām, dažādām organizācijām un/vai departamentiem: šiem jauniešiem ir arī uzvedības problēmas skolā, viņiem ir nosliece būt negatīviem un agresīviem, un skolai bieži vien pietrūkst iekšējo resursu, lai pārvarētu problēmas, strādātu ar viņu motivāciju un rastu labākos risinājumus." Un, izsakot nožēlu par ierobežoto iespēju iesaistīt darbā ar problemātiskajiem jauniešiem perspektīvos jauniešus, tiek vispārinoši secināts, ka “[..] nav viegli kaut ko uzsākt bez zināšanām, informācijas un saprašanas. Tas koordinācijas deficīts mūsu izglītojošajās un informatīvajās aktivitātēs var tikt attiecināts uz sabiedrïbu kopumā”, jo nav skaidrības, kura institūcija ir atbildīga, kura ir iesaistīta un kura veic specifiskās aktivitātes.

\section{Cilvēciskais faktors}

Kontekstā ar varas pārstāvju - politikas veidotāju un lēmumu pieņēmēju - cilvēciskajām, psiholog̣iskajām īpašībām, kā arī ar viņu 
vērtību orientāciju un interesēm sociālo pakalpojumu profesionāli min cilvēcisko faktoru, kas ietekmē sociālos procesus. No tā ir atkarīga jurisdikcija - likumi un daudzi sociālie procesi, tai skaitā normatīvi, kas regulē sociālos pakalpojumus. 2017. gadā notiek parlamenta vēlēšanas Vācijā, 2018. gada 6. oktobrī - Latvijā. 2017. gada 3. jūnijā Latvijā notiek pašvaldību vēlēšanas. Augstākās un vietējās varas vēlēšanas pievērš vācu un latviešu sociālo pakalpojumu sniedzēju uzmanību. "Valdības maiņa būs liels izaicinājums. Jaunie sociālie likumi tiks korig̣ēti, un mēs varam vien cerēt, ka jaunais vienlīdzības likums tiks saglabāts," tā savas bažas pauž vācu speciālisti sociālās labklājības jomā.

Latvijas pārstāvji izsaka savas bažas gan emocionāli, gan racionāli: "Kaut ātrāk paietu šis pašvaldību vēlēšanas, lai būtu redzams, kas, tas ir, kādi cilvēki, nāks pie varas," - tā tiek raksturota pirmsvēlēšanu nenoteiktības situācija. Sociālo pakalpojumu finansiālo atkarību no vietējās varas pārstāvju politiskās orientācijas un vērtỉbu sistēmas cits Latvijas speciālists pēc ilglaicīgās pieredzes un novērojumiem izsaka šādiem vārdiem: "[..] personas, kas atrodas pie varas, it neko nedara ilglaicīgā perspektīvā.” Sociālo pakalpojumu speciālisti Latvijā ievērojuši vēl tādu likumsakarību: iesaistîšanās sociālās dzìves norisēe ir atkarīga no vadošām varas personām.

Somu speciālistiem par personām, kas ieņem varas pozīcijas, ir savs spriedums: "Amatpersonu izglìtības trūkums liedz tiem lietot tādu somu valodu, ko varētu saprast arī tie, kam somu valoda nav dzimtā valoda." Šì piezīme ir attiecināma uz gandrīz jebkuras valsts oficiālo birokrātisko un juridisko valodu un liecina par plaisu starp varas personām un parasto cilvēku. Atsvešinātība starp politikiem un tautu ir izplatìta parādība tādēl, ka viņiem visai bieži ir zema inteliǵence, viņi neievēro ētikas normas un rīkojas savtīgi. Tas rada uzticēšanās trūkumu vai pilnīgu tās zudumu.

Cilvēciskais faktors izpaužas arī jau iztirzātajā negativitātē, kas raksturīga attieksmei pret sociāli neveiksmīgām un/vai citādām grupām. Izglìtotā, mācītā, labklājīgā sabiedrībā tā izpaužas mazāk vai arī tiek labāk apslāpēta un slēpta. Netrenētā un mazāk labklājīgā sabiedrībā negatīvā attieksme tiek pausta tieši un atklāti, tā ne mazākā mērā netiek pakḷauta paškontrolei.

Cilvēciskais faktors ir attiecināms vēl uz vienu aǵentu sociālajā mijiedarbībā. Tie ir sociālo pakalpojumu galalietotāji. Viṇu domāšanas un rīcības modeḷu īpatnības ir nopietns pārbaudijums un stresa avots 
sociālo pakalpojumu sniedzējiem. Tiek minētas tādas pakalpojumu lietotāju domāšanas un rīcības modeḷu ỉpatnības: cilvēku ar invaliditāti pasivitāte, problemātiskās jaunatnes dạ̧as tādas uzvedības izpausmes kā alkohola un narkotisko vielu lietošana, agresivitāte, skolas neapmeklēšana, nesekmīgas atzīmes, bēgšana. Vēl vairākkārt tiek pieminēta ilgstošo bezdarbnieku un problemātiskās jaunatnes zemā pašcieņa, kas viṇiem savu dzīves situāciju kavē mainīt pret labāku.

\section{Secinājumi}

\section{Secinājumi par barjerām un šḳēršliem sociālo pakalpojumu organizāciju darbā}

Vispārinot 2017. gada papildpētījumā par barjerām un šḳēešliem iegūtās informācijas saturu, īsumā ir secināms, ka tika iegūta padzilināta un paplašināta informācija par barjerām un šḳēršliem sociālo pakalpojumu organizāciju darbā, otrkārt, apstiprinājās informācija, ko partneri bija snieguši pirms gada, treškārt, vienam gadam paejot, pārmaiṇas netika uzrādītas.

Materiālie šḳēešsli kopumā nav nedz skaitliski lielākie, nedz nozīmīgākie šķērṣ̌li. Izṇēmums ir sabiedriskā transporta pieejamība laukos. Tiek minēti trīs materiālie šḳēršlı: nauda, telpas un sabiedriskais transports.

1. Nauda/finanses. Par finanšu nepietiekamību vai par to, ka pēdējā laikā finanses tiek samazinātas sociāliem pakalpojumiem, bažas izteikuši vācu un somu pakalpojumu sniedzēji.

Naudas ierobežojums personālam parādās norādēs par tā zemo atalgojuma lìmeni.

2. Telpas. Par to, ka jauniešiem trūkst telpu, kur varētu pulcēties, žēlojas poḷu partneris, par imigrantu un vietējo iedzīvotāju kopīgās pulcēšanās telpu trūkumu runā zviedru partneri. Telpu stāvokḷa uzlabošana ir aktualitāte, ko min Latvijas partneri no Vidzemes.

3. Sabiedriskā transporta pieejamības ierobežojumi regionu lauku dzives vidē ir visbiežāk minētais materiālais škēerslis. Tos ir nosaukuši visu dalībvalstu partneri, izṇēmums ir Zviedrija. Latvijā sabiedriskā transporta pieejamība laukos kḷūst aizvien ierobežotāka, kopš 2009. gadā tika konsolidēts budžets jeb drastiski taupits uz 
sociālo pakalpojumu finansēšanas samazināšanas un darba ņēmēju algu samazināšanas rēḳina, lai, pārvarot finanšu spekulantu izraisìto ekonomisko krīzi, glābtu no bankrota privātu banku par nodokḷu naudu un pasargātu no zaudējumiem visbagātāko sociālo slāni.

\section{Nemateriālas barjeras un šķēršļi}

Biežāk minētas ir nemateriālas iedabas barjeras un šķēššli. Tie ir juridiski, darba organizatoriskie un sociālās un individuālās psihologíjas jautājumi. Psiholoǵiskā problemātika ir aktuāla abām pusēm - pakalpojumu sniedzējiem un saņēmējiem.

Juridiskie šḳēršlı. Tie ir atškirīigi atkarībā no pakalpojumu lietotāju kategorijām un valstu specifikas. Juridiskie šḳērṣ̌li rodas trīs iemeslu dẹl, Tie ir: likumdošanas mainišana, likumu trūkums un juridisko normu harmonizācijas līmenis. Tā Dānijā sociālo pakalpojumu sniegšanu bēgḷiem kavē saskaņota likumdošanas kopuma trūkums. Somijā pakalpojumu sniegšanas (bēg̣̣iem un imigrantiem) juridiskās regulācijas reformas situāciju padara kritisku. Likumdošanas mainī̌ana nozīmē nenoteiktību, kas mulsina un kavē pārliecinošu rīcību. Pārejā no integrācijas pakalpojumiem uz vispārējiem pakalpojumiem somu speciālistu novērtējumā "viṇi (bēg̣̣i - A. S.) bieži iekrìt kā aizā". Latvijā 2017. gada pirmajā pusē speciālisti pauda neapmierinātību par sociālās uzṇēmējdarbības likumiskās regulācijas neesamību. 2017. gada oktobrī Sociālā uzṇēmuma likums tika pieņemts, un 2018. gada aprīlī tas ir stājies spēkā. Latvijā aktualizētā deinstitucionalizācijas programma normatīvā regulējuma trūkuma dẹl speciālistiem ir radījusi nenoteiktỉbas izraisìtu stresu.

Pakalpojumu sniedzēju psihologiskās problēmas ir izvairīšanās no refleksijas par pārmain̦ām, izdegšanas sindroms, negatīvo emociju, ko izjūt pakalpojumu lietotāji, pārstrādāšana, pakalpojumu saṇēmēju valodas nezināšana.

Bez psihologiskās problemātikas jāmin arī speciālistu norādītās reizēm sastopamās subjektīvās atškiriribas starp sociālo pakalpojumu sniedzējiem un sañēmējiem vajadzību izvērtēšanā. Abu pušu uzskati un priekšstati par pakalpojumu lietotāju vajadzībām mēdz stipri atšḳirties.

Multikulturālā sabiedrība un komunikācija rada virkni savstarpējās saprašanās barjeru. Tās ir valodas, ieradumu, paražu, uzvedības normu atšķirības. 
Pakalpojumu lietotāju psihologiskās problēmas, ko novērojoši speciālisti, ir demotivācija pārmaiņām, tradicionāls lomu modelis, bailes, bēgḷu un imigrantu izvairīgās atbildes par dzìvesvietu kā šķērsli viņu ātrākai integrācijai, bēgḷu un imigrantu psihologiskās traumas, kuras izraisījusi kara pieredze.

Pakalpojumu saṇēmēju zemais izglìtības līmenis sasaistās ar sociālo prasmju un situāciju risināšanas prasmju trūkumu.

Valodas barjeras tiek minētas kā šḳērslis un barjera tiem partneriem Dānijā, Somijā, Vācijā un Zviedrijā, kuri sniedz pakalpojumus bēgliem un imigrantiem. Pastāv abpusējas valodas barjeras, jo imigrantiem ir nepietiekamas vietējās valodas zināšanas, pakalpojumu sniedzējiem nav imigrantu valodu zināšanas. Tulki ne vienmēr ir pieejami, un tulku algošanai organizācijām jo bieži nav naudas.

Kultūru atšķirības, kas izpaužas uzvedības normās un paražās, izraisa nesaprašanos starp pakalpojumu saṇēmējiem un sniedzējiem darbā ar bēgḷiem un imigrantiem.

Dezintegrācija sabiedrībā ir izplatīta parādība, un tā izpaužas pēc daudzām identitātes pazīmēm: pilsonības, etniskās piederības, piederības pie noteiktas vecumgrupas un starppaaudžu attiecībās. Igauṇu partneri atzīst, ka kopumā sabiedrībā vērojama sirsnīgas, draudzīgas kopdzīves jeb konvivialitātes mazspēja, deficīts un nepratība.

Komunikācija, darbu koordinācija un informācijas aprite ir visai nozīmīgs organizatoriskā rakstura barjeru kopums, kuru cēlonis ir menedžmenta atslābināts darba režīms. Šì problemātika tiek konstatēta starp viena līmeṇa sociālo pakalpojumu organizācijām un starp subordinētām augstākstāvošām un tām pakḷautām zemākstāvošām institūcijām.

Noslēgumā vispārīgi secinājumi par spēcināšanas vietu sociālekonomiskā konteksta galvenajiem informācijas blokiem.

\section{Vispārīgi secinājumi par statistiskiem datiem}

Statistiskie dati par pirktspējas standartu, apdzivotības blīvumu un iedzīvotāju sastāva pārmaiņām partnerības vietās ir stipri atšķirīgi. Tam visam ir logisks, sociāls, ekonomisks un uz fizikālo apstākḷu savdabību balstīts izskaidrojums.

Apdzivotības blīvums un pārmaiṇas iedzìvotāju sastāvā ir savstarpēji saistīti rādītāji. Pamatcēloṇi zemam apdzīvotības blīvumam 
un novecošanai kā raksturīgākai pazīmei iedzīvotāju sastāva pārmaiņās līdzās depopulācijai ir skaudri klimatiskie vai skarbi sociālie un ekonomiskie dzīves apstākḷi. Zviedrijas un Somijas ziemeḷos skaudrais klimats, ko ietekmē šo valstu geogrāfiskais stāvoklis, nav pievilcīgs dzīvošanai, bet šajās valstīs to daḷēji kompensē labvēlīgie ekonomiskie rādītāji, kas vismaz uz kādu laiku cilvēkus piesaista šai vietai un notur. Cēlonis tam, ka klimatiski labvēlīgākos apstākḷlos Latvijā iedzīvotāju blīvums ir tikpat zems kā tajās Somijas vietās, kas atrodas daudz tālāk uz ziemel̦iem, ir Latvijas lauku apdzīvoto vietu nelabvēlīgie sociālie un ekonomiskie dzīves apstākḷi - darbavietu trūkums, smags darbs, zems atalgojums, nabadzība, sociālo, medicīnas un kultūras pakalpojumu pieejamības ierobežojumi -, tāpēc lauku iedzīvotāji aizbrauc uz pilsētām. Liels skaits Baltijas valstu iedzīvotāju kā ekonomiski bēg̣̣i dodas arī uz ārzemēm. Ekonomiski aktīvie darbspējas vecuma pieaugušie un jaunieši aizbrauc no laukiem, jo pilsētās paveras iespēja iegūt augstāku izglìtību un atrast darbu. Šis process uzskatāmi ir izpaudies Baltijas valstu pārejas sabiedrībās.

Urbanizācijas tendence kā joprojām notiekošs process arī ir ņemama vērā. Tā vēl arvien turpinās, jo pilsētvide piedāvā daudz vairāk iespēju salīdzinājumā ar lauku dzīves vidi un citu dzīves stilu. Urbanizācija ir viens no iemesliem, kāpēc laukos iedzīvotāju kḷūst mazāk un palielinās vecāka gadagājuma cilvēku īpatsvars.

Vispārīgās ar iedzīvotāiiem saistītās dominējošās attīstības tendences lauku dzīves vidē ir izsakāmas ar diviem terminiem: depopulācija un populācijas novecošana.

Iedzīvotāju skaita pieaugums SEMPRE projekta īstenošanas vietās Somijā, Dānijā un Zviedrijā (tās klimatiski skaudrā reg̣ionā) ir hipotētiski izskaidrojams ar imigrācijas plūsmu virzī̌anu uz šiem regioniem no citu kontinentu valstīm, kas ir ekonomiski izpostītas ilgstošo sociālo konfliktu rezultātā, un no bijušās PSRS valstīm.

\section{Vispārīgi secinājumi par vietu īpatnībām}

Informācija, kas norādīta respondentu atbildēs uz jautājumu par vietu īpatnībām, liecina par šādām vietu ekonomiskām īpatnībām un atškiirībām: Vācijas partneris no Plēnes norāda, ka lauksaimniecībai raksturīga sezonāla nodarbinātība. Baltijas valstīm raksturīgs rādītājs ir augsts bezdarba līmenis, ekonomiskā depresija un cilvēku depresija. 
Salīdzinājumam l̦oti zems bezdarba līmenis un zems nodarbinātības līmenis privātā sektorā tiek norādīts saṇemtajās ziṇās par Dāniju.

Atbildēs par vietu īpatnībām ir minētas migrācijas plūsmas. Tās notiek divos pretējos virzienos - migrējot no laukiem uz pilsētām un emigrējot uz ārzemēm (tas ir izplatīts process Baltijas valstīs). Sociāli un ekonomiski labklājīgās Skandināvijas valstis un Vācija ir atraktīvs imigrācijas galamērḳis.

Cita zīmīga vietu ìpatnība, kas norādīta atbildēs, ir saistīta ar infrastruktūras kvalitāti un stāvokli. Baltijas valstīs daudzviet ir ierobežota izglítības, veselības aprūpes, pasta, banku, veikalu pakalpojumu pieejamība. Un pagaidām sociālo pakalpojumu pieejamība regionos turpina pasliktināties.

Zviedrijā Norbotenas lēnes īpatnība ir izteikts profesionāļu trūkums sociālajā jomā un medicīnā.

Sabiedriskā transporta pakalpojumi ir problemātiski daudzviet. Projekta vietās Dānijā autoceḷu tîkla kvalitāte tiek raksturota kā laba, bet sabiedriskā transporta pieejamība ir tāda, ka mobilitāte bez personiskā auto ir stipri apgrūtināta vai pat neiespējama. Lìdzịgi ir Vācijā Plēnē un Ziemeḷ̂fīzlandē.

Latvijas reǵionos lauku dzīves vidē mazinās sabiedriskā transporta pieejamība un autoceḷu stāvoklis daudzviet ir kritisks.

\section{Vispārīgi secinājumi par faktoriem, kas ietekmē sociālo pakalpojumu galalietotāju dzīves apstākḷus}

Sociālo pakalpojumu galalietotāju dzīves apstākḷu raksturojums liek secināt, ka šie cilvēki vairāk vai mazāk atrodas diskomforta zonā. Galvenie faktori, kas ietekmē vinuu dzives apstākḷus, ir bezdarbs, mobilitātes ierobežojumi sabiedriskā transporta nepieejamības dēl un sava auto neesamība naudas trūkuma, veselíbas stāvokḷa vai citu iemeslu dēḷ. Neapšaubāms fakts ir sabiedrības dezintegrācija pēc sociālās stratifikācijas nabagos un bagātos, pēc piederības pie citas rases, etnosa, pēc tādām atšḳirībām kā invaliditāte, devianta uzvedỉba. Sociālā dezintegrācija izpaužas daudzējādi, arī kā telpiskā segregācija - sociāli līdzīgie ierobežo un norobežo savu dzīves, darba un komunikācijas telpu.

Psihologiskās problēmas ir izplatīts un būtisks faktors, kas ietekmē šo cilvēku dzìvi. Viṇiem tiek piedēvētas šādas psiholoǵiskās ìpašības un stāvokḷi: nenoteiktības un neziņas radīts diskomforts, 
dažādu vardarbỉbas veidu izraisìta psihologiska trauma, bezcerība, apātija, motivācijas trūkums, sociālo prasmju deficīts, neprasme tikt galā ar dažādām dzīves situācijām. Vientulība tiek pieminēta saistîbā ar vecāka gadagājuma personām Somijā un personām ar invaliditāti Latvijā.

\section{Vispārīgi secinājumi par barjerām un šḳēršliem sociālo pakalpojumu sniedzēju darbā}

Barjeras un šḳēršli sociālo pakalpojumu organizāciju darbā izpaužas kā daudzveidīgi apgrūtinājumi un problemātika. Atškşirības determinē valstu atšḳirības un daudzveidīgo pakalpojumu lietotāju kategoriju atšķirības. Darbā ar katru pakalpojumu lietotāju kategoriju ir sava darba specifika. Tādēḷ veiksmīgāku darbu un tā rezultātu nodrošina sociālo pakalpojumu sniedzēju specializācija.

Iegūtā informācija liecina, ka kopumā materiālie šḳēršli pakalpojumu sniegšanā nav galvenie. Par finanšu nepietiekamību kā šķērsli pakalpojumu sniegšanā izsakās tie somu un vācu sociālo pakalpojumu sniedzēji, kas strādā ar bēg̣̣iem un imigrantiem. Vairāk naudas būtu vajadzīgs valodu kursiem un tulku atalgošanai. Taču Baltijas jūras regionā ir valstis, kur sociālo pakalpojumu organizāciju personāls tiek atalgots neadekvāti zemu.

Neapmierina arī sabiedriskā transporta pieejamības ierobežojumi reǵionu lauku dzīves vidē. Tas ir visbiežāk minētais materiālais šḳērslis. Sabiedriskā transporta pieejamība ir akūta problēma, kurai ir jāmeklē risinājumi.

Padzilinātajā barjeru un šḳērš̌lu apzināšanā respondentu atbildes atklāja daudz plašāku problēmu klāstu, konkretizējot vairāku problēmu saturu. Atbildēs tika sniegts daudz plašāks psihologisko problēmu izklāsts, kā arī ziṇas par iepriekš neminētu būtisku problemātiku, kas ietekmē darbu. Tā ietver, piemēram, societālas barjeras, kas faktiski ir sociālās psihologijas izpausme visas sabiedrības mērogā, komunikāciju, darbu, rīcības, informācijas aprites koordinācijas kvalitāti, kas būtu uzlabojama, pie varas esošo personu īpašîbu, vērtību, interešu un lēmumu ietekme uz sociāliem procesiem un sociālo pakalpojumu sniegšanu.

Societālas barjeras šajā projektā izpaužas kā dažāda negatīva attieksme pret atškiirībām, citādību, svešību. Tā ir izskaidrojama ar 
izdzīvošanas instinktu un psihes dzīlēs mìtošām bailēm. Bezapzinīga un reizēm reāla apdraudējuma izjūta izraisa negativitāti pret jebkuru svešinieku.

Psihologiskās problēmas skar sociālo pakalpojumu organizāciju profesionāḷus visai dziḷi, jo darbs ar pakalpojumu lietotājiem noris patstāvīga, paaugstināta stresa apstākḷos. Gadījumu analīze, situāciju risināšana un komunikācijas stils rada distresu un hiperstresu.

Komunikācija un koordinācija ir nozīmīgi faktori, kuri ietekmē darbu un par kuriem sniegts daudz kritisku ziņu. Tās abas tiek raksturotas kā neapmierinošas un apgrūtina ikdienas darbu. Komunikācijā sarežğijumiem ir vairākas dimensijas. Rodas sarežğijumi komunikācijā ar kolēgiem, vadību un pakalpojumu lietotājiem.

Darba, rīcỉbas koordinācijas un informācijas apmaiṇas operativitātes nepietiekamība ir būtiskākās nepilnības subordinētajā komunikācijā starp augstāk un zemāk stāvošām sociālās labklājības institūcijām.

Informācijas aprites operativitātes, komunikācijas un koordinācijas kvalitātes uzlabošana tiek aktualizēta kā neatliekama nepieciešamìba.

\section{leteikumi}

1. Pieṇemot lēmumu par infrastruktūras objektu likvidāciju lauku apdzīvotās vietās, pamatoties uz ilglaicīgu stratēgisku perspektīvu, nevis uz konkrētā brīža ekonomisko izdevīgumu - naudas izdevumiem. Ja infrastruktūras konsolidācija ir vienīgais risinājums, tad piedāvāt alternatīvas. Gudra, atbildīga un laba pārvaldība lēmumu pieņemšanā nozīmē ilglaicīgu stratēgiju un apsvērumu, ka pastāv vērtības, kas naudā nav samaksājamas un izsakāmas.

2. Lauku apdzīvoto vietu paglābšana no iztukšošanās un izzušanas no Latvijas kartes ir saistìta ar ekonomiskās aktivitātes iedzīvināšanu, ražotņu izveidošanu un sociālo pakalpojumu pieejamības nodrošināšanu. Daži mēgeinājumi tās radīt Latvijā beigušies nesekmīgi, jo vietējie iedzīvotāji tiek ietekmēti - viņiem tiek iestāstîts, ka ražotņu izveidei ir jāpretojas, jo ražošana piesārṇošot vidi. Ja valsts un vietējās pašvaldības ir gudras un atbildīgas, tad 
ražošanas izraisītā vides piesārṇošana kontrolēti var tikt reducēta lìdz minimumam.

3. Mobilo sociālo pakalpojumu piegāde un nodrošināšana aprūpei mājās vecāka gadagājuma personām un personām ar invaliditāti ir viens no risinājumiem vietās, kur sociālo pakalpojumu infrastruktūra likvidēta vai izzudusi, ja viņi lauku dzives vidē dzīvo vieni un šai vidē nenotiek nekādas pozitīvas pārmaiņas. Mobilie sociālie pakalpojumi daudzviet sevi apliecinājuši kā labu praksi. Latvijā mobilo sociālo pakalpojumu piegādi un aprūpi mājās piedāvā Latvijas Samariešu apvienība. Šādam pakalpojumu tỉklam būtu jāpārklāj visa Latvijas teritorija. Pašvaldību sociālie dienesti būtu tie aǵenti, kas organizē mobilo sociālo pakalpojumu pieejamību tiem, kam tie ir vajadzīgi. Maksāt par pakalpojumiem varētu gan paši to lietotāji, gan pašvaldība, ja to lietotāji nav maksātspējīgi.

4. Sabiedriskā transporta pieejamības jautājums ir risināms, racionāli veidojot transporta kursēšanas grafiku, šo pakalpojumu subsidējot no nodokḷu ieñēmumiem un meklējot inovatīvus risinājumus transporta pakalpojumiem laukos. Te varētu izpausties iedzìvotāju pašiniciatīva kā labas kopā dzīvošanas spēja vai vietējās pašvaldības organizēts transporta pakalpojums, apspriešanās rezultātā izlemjot, kad un kur notiks braucieni, lai apmierinātu sadzìviskās vajadzības. Transporta problemātika laukos ir l̦oti aktuāla, tāpēc tās risinājumi pašlaik tiek meklēti arī kādā Eiropas Savienības Interreg programmas Baltijas jūras reǵiona valstu projektā, kurā ir iesaistìta arī Latvija.

5. Atkārtoti izskatīt valsts pārvaldības decentralizācijas principa piemērošanu. Funkcijām adekvātu valsts pārvaldības institūciju pārvietošana no Rīgas uz reǵioniem veicinātu vietējo saimniecisko darbību un nodarbinātību vismaz servisu jomā.

6. Aktuāls uzdevums ir sociālo pakalpojumu sniedzēju profesijas prestiža celšana. Svarīgs nosacījums tam ir atalgojuma kāpinājums, izvērtējot šì darba augsto spriedzes līmeni un nozīmi sociālā miera uzturēšanā. Tāpat personāls ir preventivi aizsargājams no psiholog̣iskās izdegšanas gan racionālā darba laika organizēšanā, gan darba veidu sadalīšanā, tos dažādojot.

7. Sociālo pakalpojumu organizāciju menedžmenta darbs ir nopietni pilnveidojams. Vadī̌̌anas funkcijas ir uzlabojamas, jo bieži 
ir pausta personāla neapmierinātība ar komunikācijas, aktivitāšu koordinācijas, kā arī informācijas aprites kvalitāti. Informācijas apmaiṇas operativitāte, aktivitāšu koordinācija, augstāk stāvošo institūciju komunikācija ar zemāk stāvošām institūcijām ir funkcijas, kuru kvalitāte ir atkarīga no vadības. Koordinācijas funkcija prasa vadīšanas personāla sasprindzinājumu. Lai šo funkciju labi veiktu, ir vajadzīga griba, pienākuma un atbildības apziṇa. Te ir plašs darba un nepieciešamo uzlabojumu lauks.

8. Aktuāls uzdevums izglītības institūcijās un darbavietās ir turpināt mainīt cilvēku domāšanas un uzvedības modeḷus. Šĩ nepieciešamība ir jūtama saistībā ar plašo psihologisko problēmu izplatību un cilvēciskā faktora lomu un nozīmi dažādos sociālos slāņos un grupās - gan sabiedrības pārvaldības līmenī, gan sabiedrības attieksmēs, domāšanas veidā un uzvedībā. Pašreizējais sociālo pakalpojumu lietotāju un daḷēji pakalpojumu sniedzēju situācija, kā arī atmosfēra sabiedrībā liecina par pārmaiṇu nepieciešamību.

Noslēgumā kā labas prakses piemērs sniegta zviedru partneru pieeja migrantu jautājuma risināšanai reti apdzīvotā Norbotenas lēnē Zviedrijas ziemel̦os:

Nozīmīgs aspekts mūsu projektā ir tas, ka pieaugošā migrācija uz Norbotenu rezultēsies jaunu pakalpojumu izveidošanā, kas uzlabos vispārējo labklājību un izaugsmi. Piemèram, tulku, dzimtās valodas skolotāju, jaunas ārzemju virtuves un pārtikas piegādes pakalpojumi, kā arī pakalpojumi citās valodās, nevis zviedru valodā un vèl kas cits. Droši, ka bùs vēl kas vairāk.

Šì pieeja ir paraugs un piemērs tam, kā var pārdomāt jebkuru problemātisku situāciju un meklēt tai risinājumu, lai uzlabotu kopējos dzīves apstākḷus.

\section{Atsauces}

Bela, B., N̦ikišins, J. (2018) Ilgtspējas sociālā dimensija: vai virzāmies pretī labklājỉbai un cieņpilnai dzìvei? Grām.: Bela, B. (zin. red.) Ilgtspējīga attīstība un sociālās inovācijas. Rìga: LU Akadēmiskais apgāds, 108.-139. lpp.

Dzenovska, D. (2012) Aizbraukšana un tukšums Latvijas laukos: starp zudušām un iespējamām nākotnēm. Rìga: Biznesa augstskola Turība, 198 lpp. 
Eurostat. Statistical data on: 1. PPS/capita in \% of EU (2013), 2. Population density (2013) and 3. Relative Population change 2011-2015. Available: http:// ec.europa.eu/eurostat/web/regions/data/database_[accessed: July 20, 2016].

Hazans, M. (2011) The Changing Face of Latvian Emigration, 2000-2010. In: Latvia. Human Development Report 2010/2011. National Identity, Mobility and Capability. Riga: ASPRI, pp. 77-101.

Latvija. Pārskats par tautas attīstību 2010/2011. Nacionālā identitāte, mobilitāte, rīcībspēja (2012) Rīga: Latvijas Universitāte, 153 lpp.

LR1. Sociālās aprūpes centru darbinieki piesaka badastreiku. Dienas ziṇas 19.09.2018. Pieejams: www.lsm.lv [skatīts 20.09.2018.].

Simmel, G. (1992) Soziologie. Untersuchungen über die Formen der Vergesellschaftung. In: Georg Simmel Gesamtausgabe (GSG). Bd. 11. Frankfurt am Main: Suhrkamp, S. 764-771.

Simmel, G. Stranger. Available: http://www.wattis.org/MEDIA/00413.pdf [accessed: December 12, 2015].

Simon, M., Mikesova, R. (2014) Population Development and Policy in Shrinking Regions: the Case of Central Europe. Prague: Institute of Sociology, Academy of Sciences of Czech Republic, $132 \mathrm{p}$.

Towards a Convivial Economy. The Contribution of a Re-formed Community Diakonia in Europe (2017) Geneva: The Lutheran World Federation, 54 p. 



\section{SEMPRE partnerība The SEMPRE Partnership}

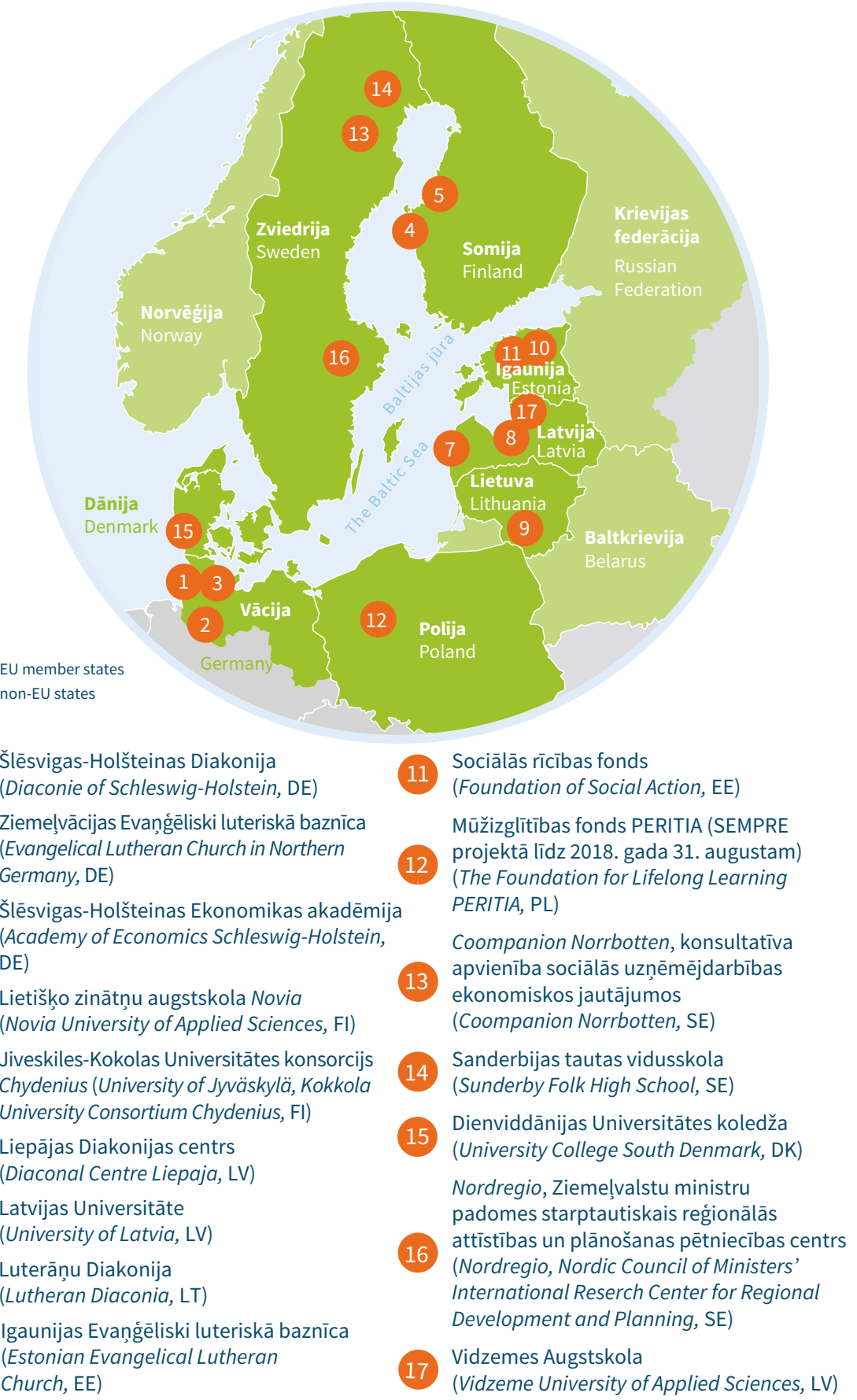




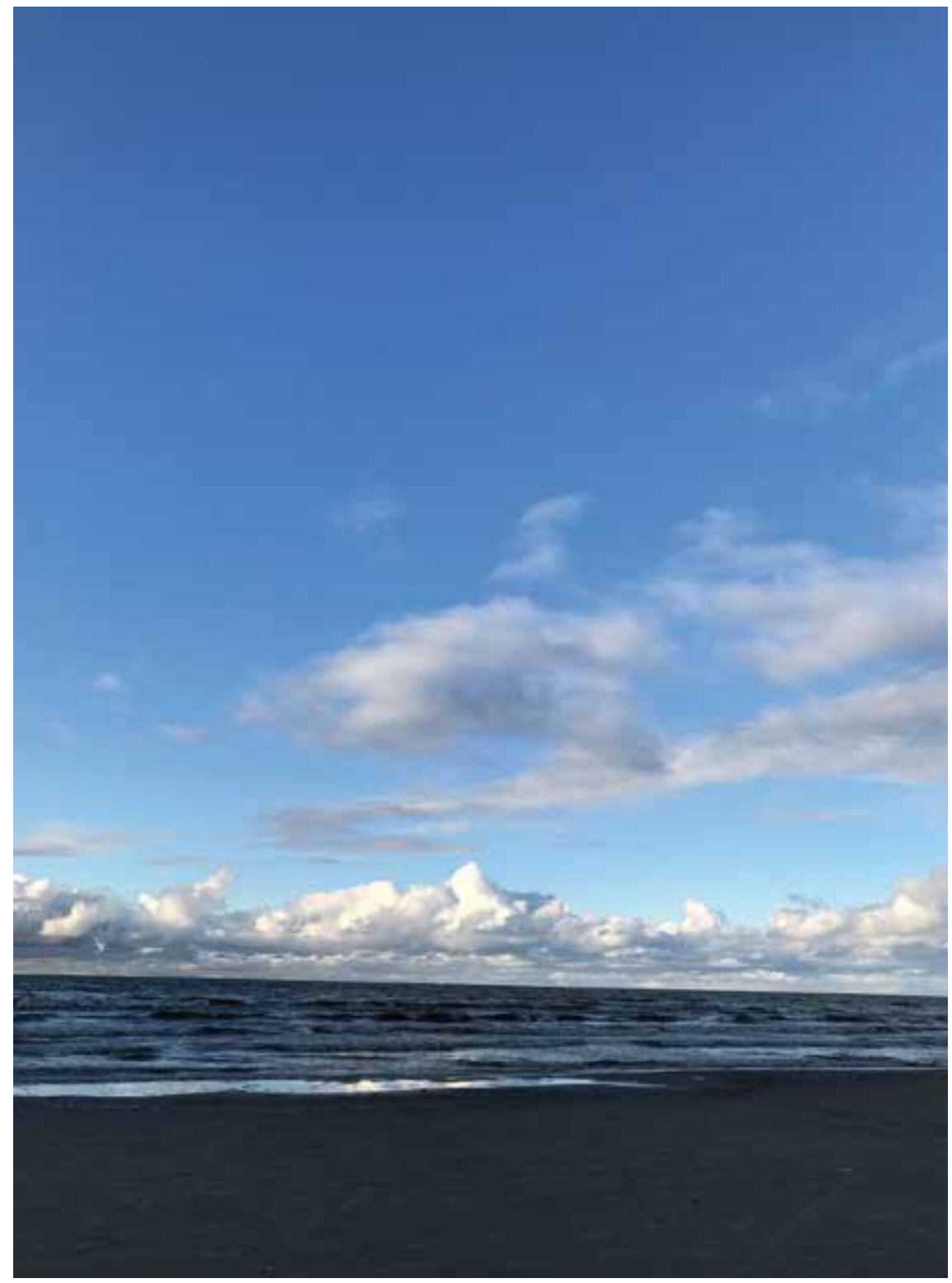

Baltijas jūra Kurzemē. Foto: Anna Stepčenko 


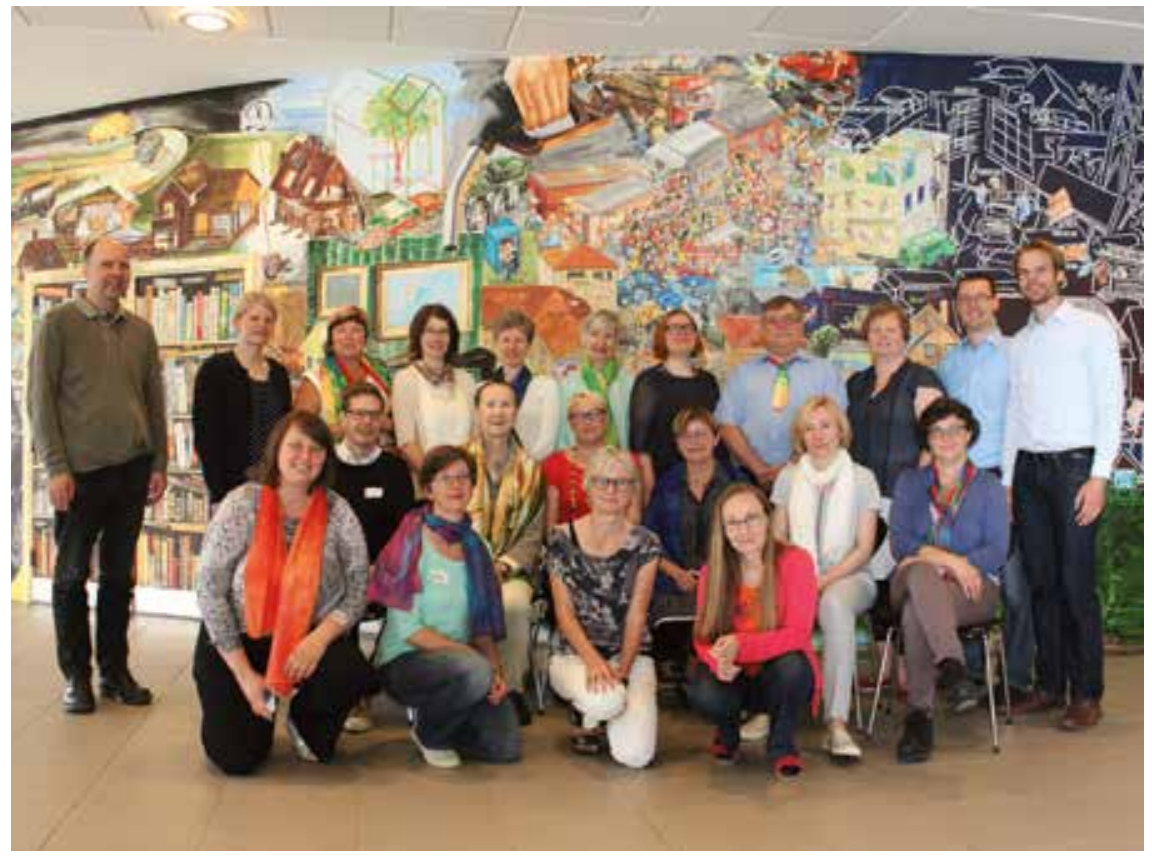

Partneru sapulces starpbrīdī Dienviddānijas Universitātes koledžā pie Ērika Hagensa (Eric Hagens) sienas gleznojuma "Jaunais evañgeēlijs”. Foto: Dienviddānijas Universitātes koledža 


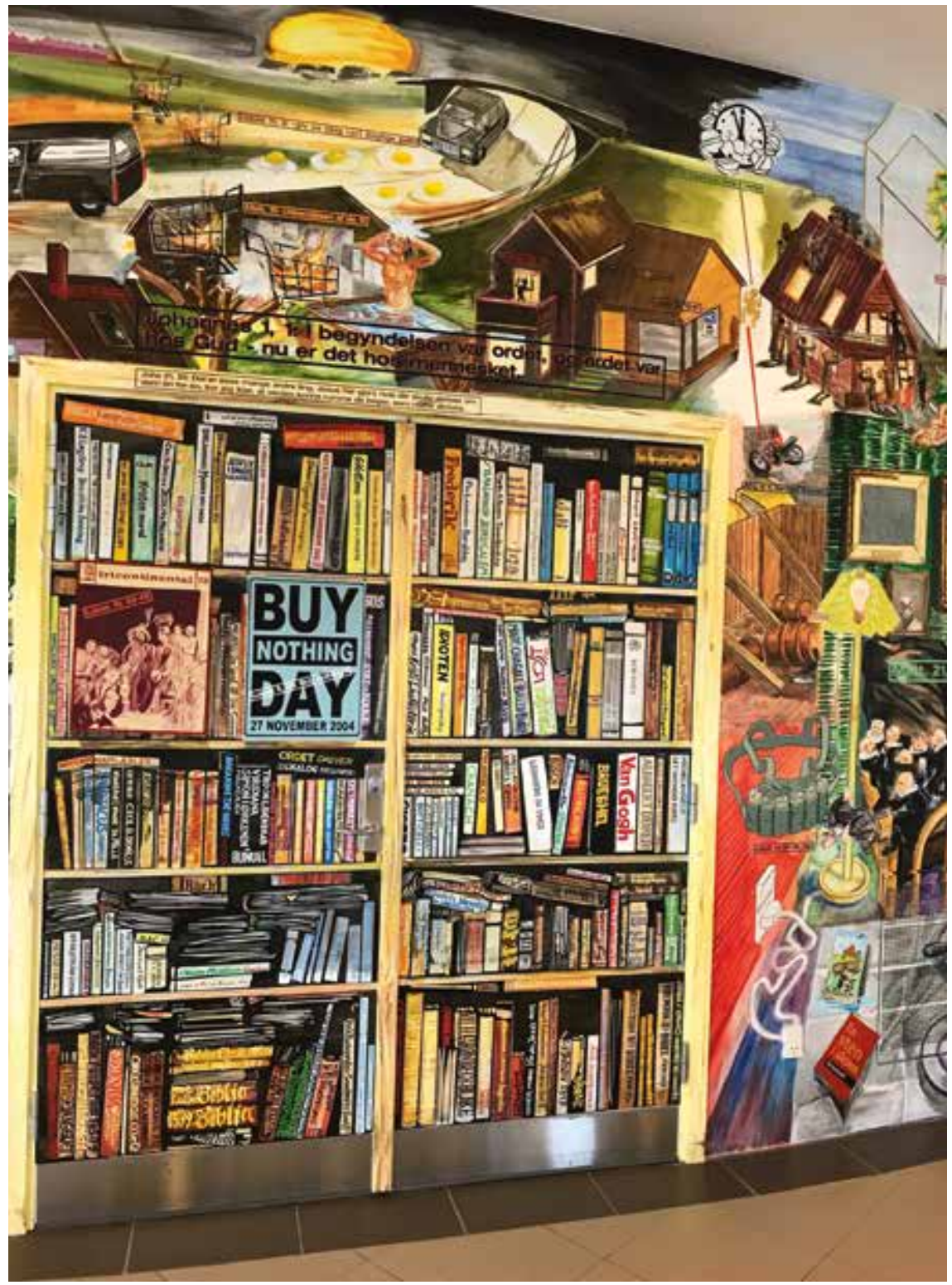

Fragments no Ērika Hagensa sienas gleznojuma "Jaunais evaņgēelijs”. Foto: Anna Stepčenko 


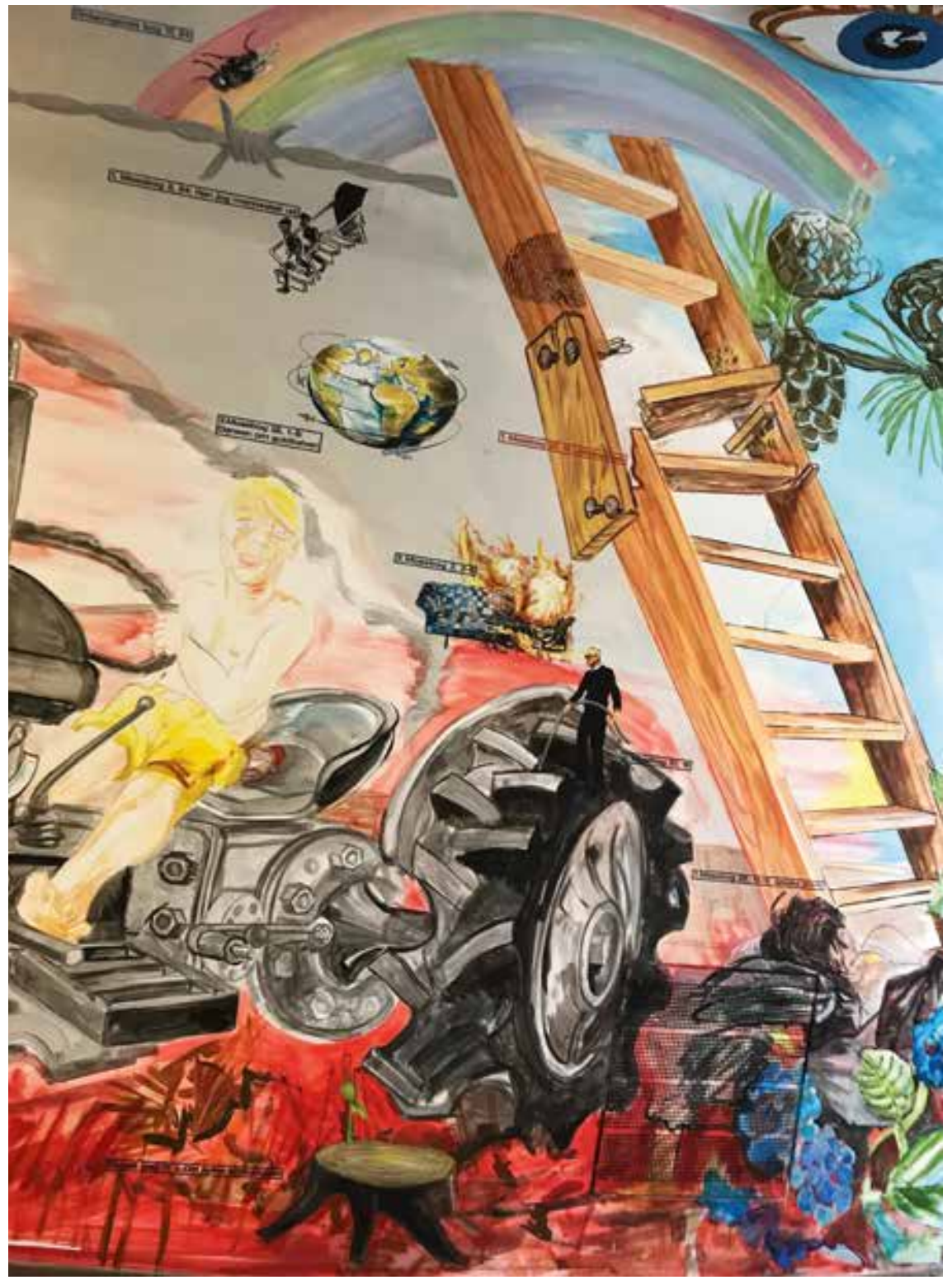

Kāpnes augšup mūsdienās. Fragments no Ērika Hagensa sienas gleznojuma "Jaunais evan,gêelijs". Foto: Anna Stepčenko 


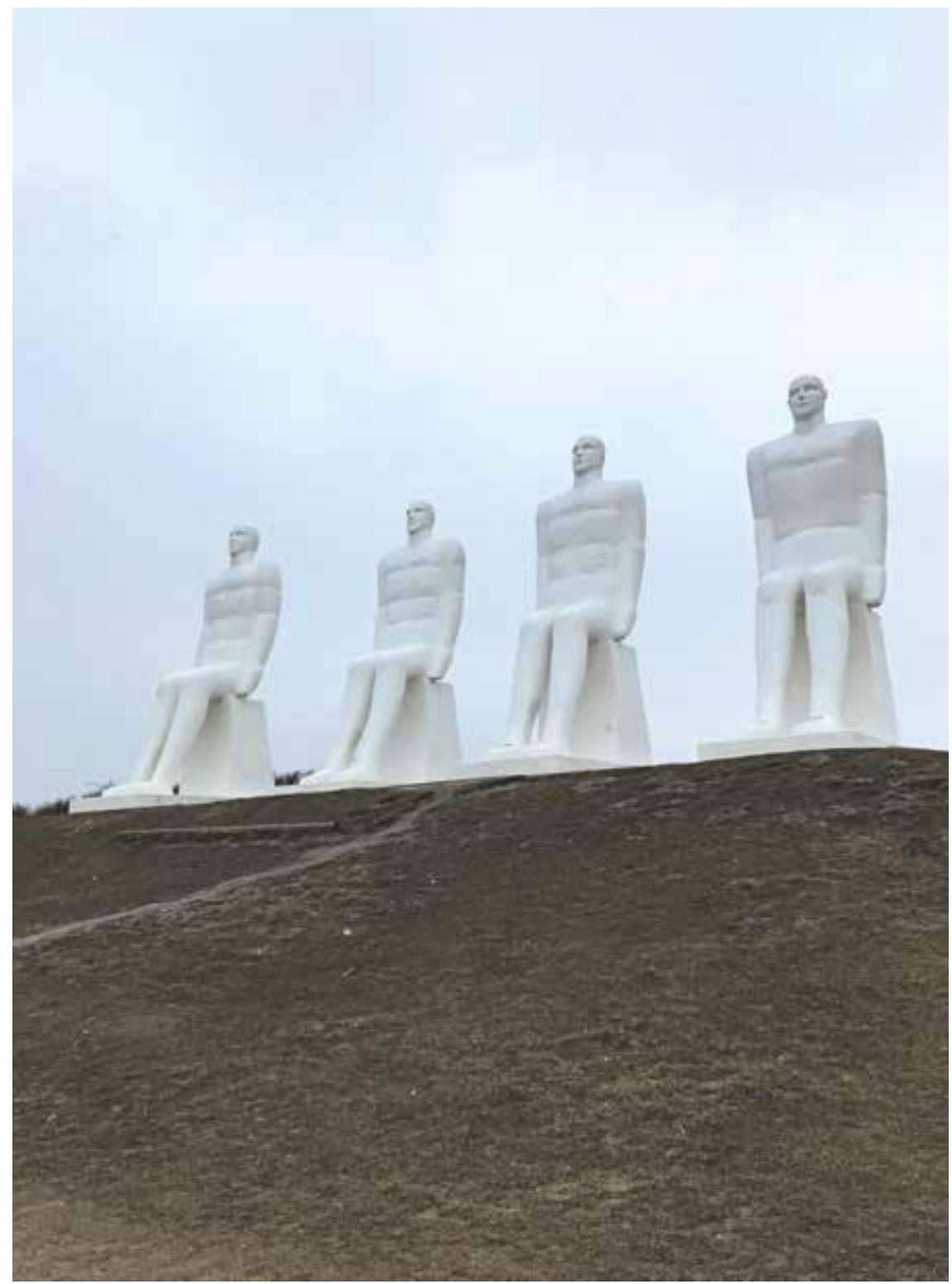

Četri cilvēki jūras krastā raugās uz horizontu, kur jūrascel̦š var aizvest uz visām četrām debespusēm. Esbjerga, Dānija. Foto: Anna Stepčenko 


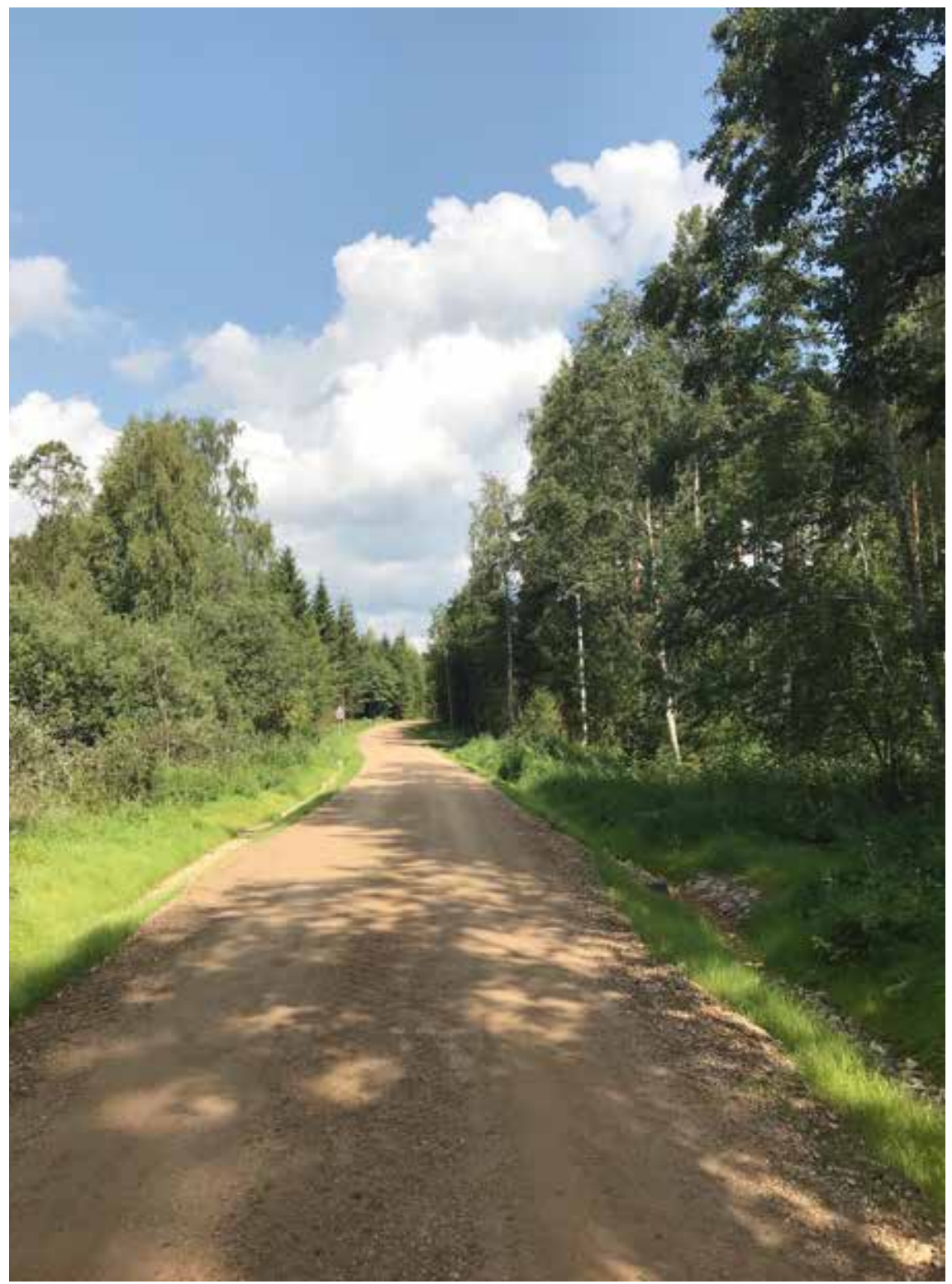

Zemescel̦š Kurzemē 2018. gada vasarā. Foto: Anna Stepčenko 


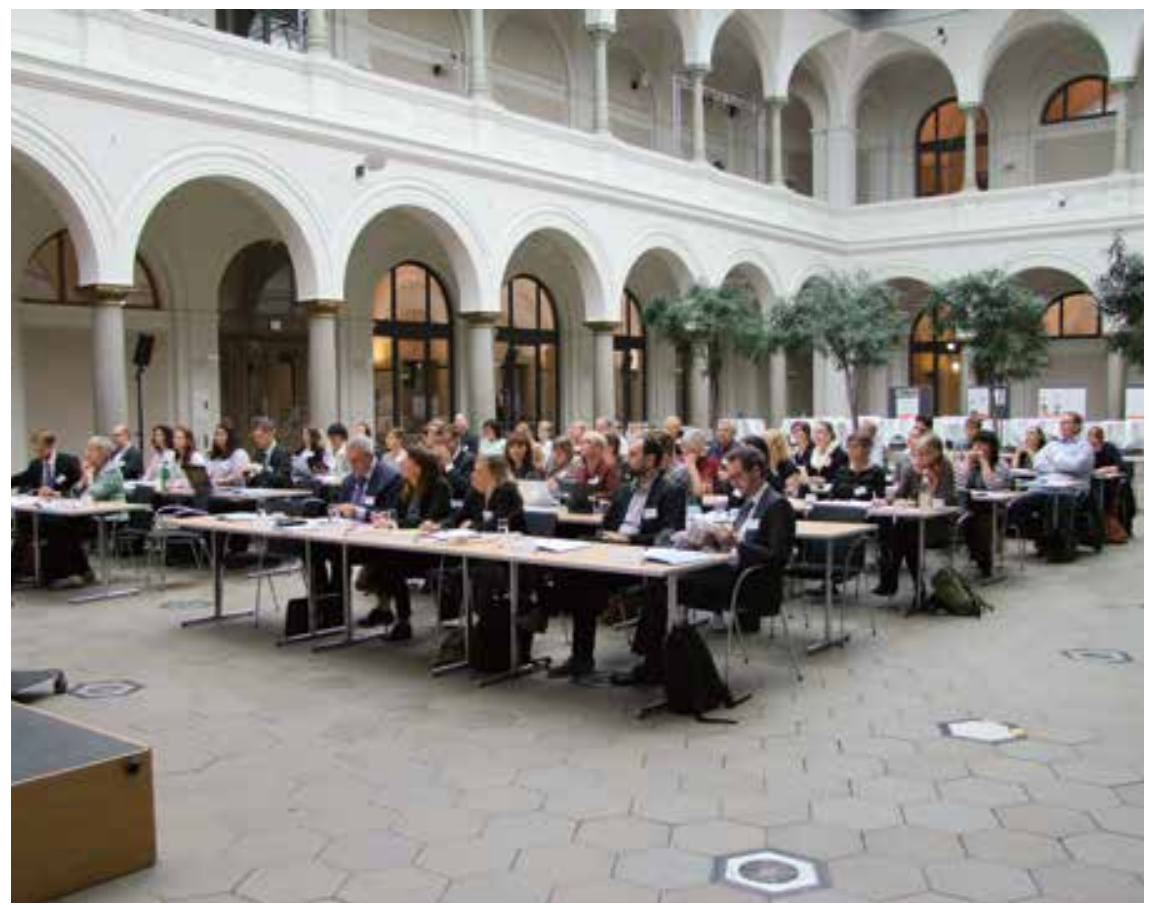

SEMPRE projekta pirmā konference 2016. gada septembrī Berlīnē. Foto: Vībke Hinca (Wiebke Hinz) 


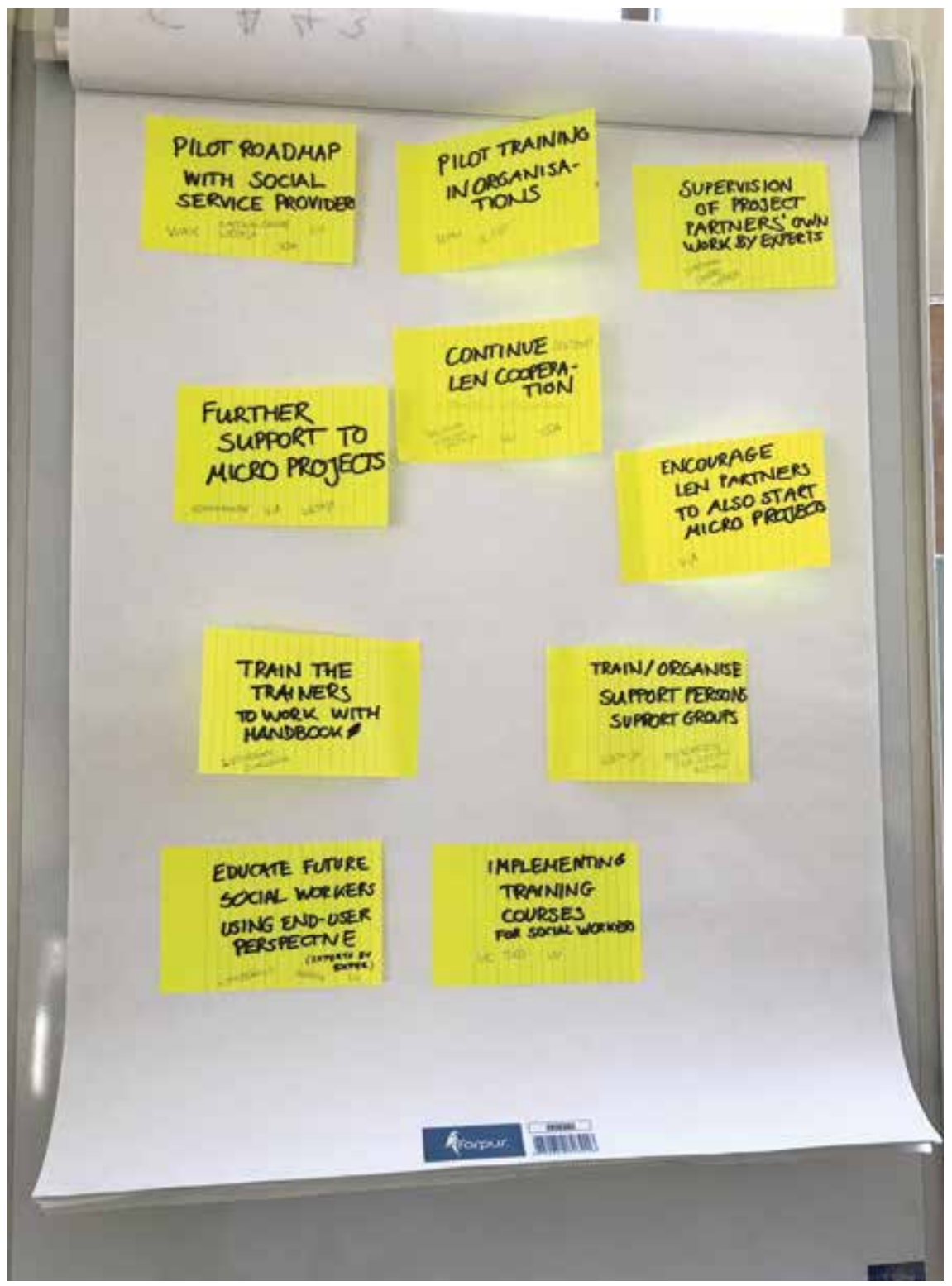

Apkopotas darba grupas idejas par mikroprojektu īstenošanu 2017. gada novembrī Esbjergā. Foto: Anna Stepčenko 


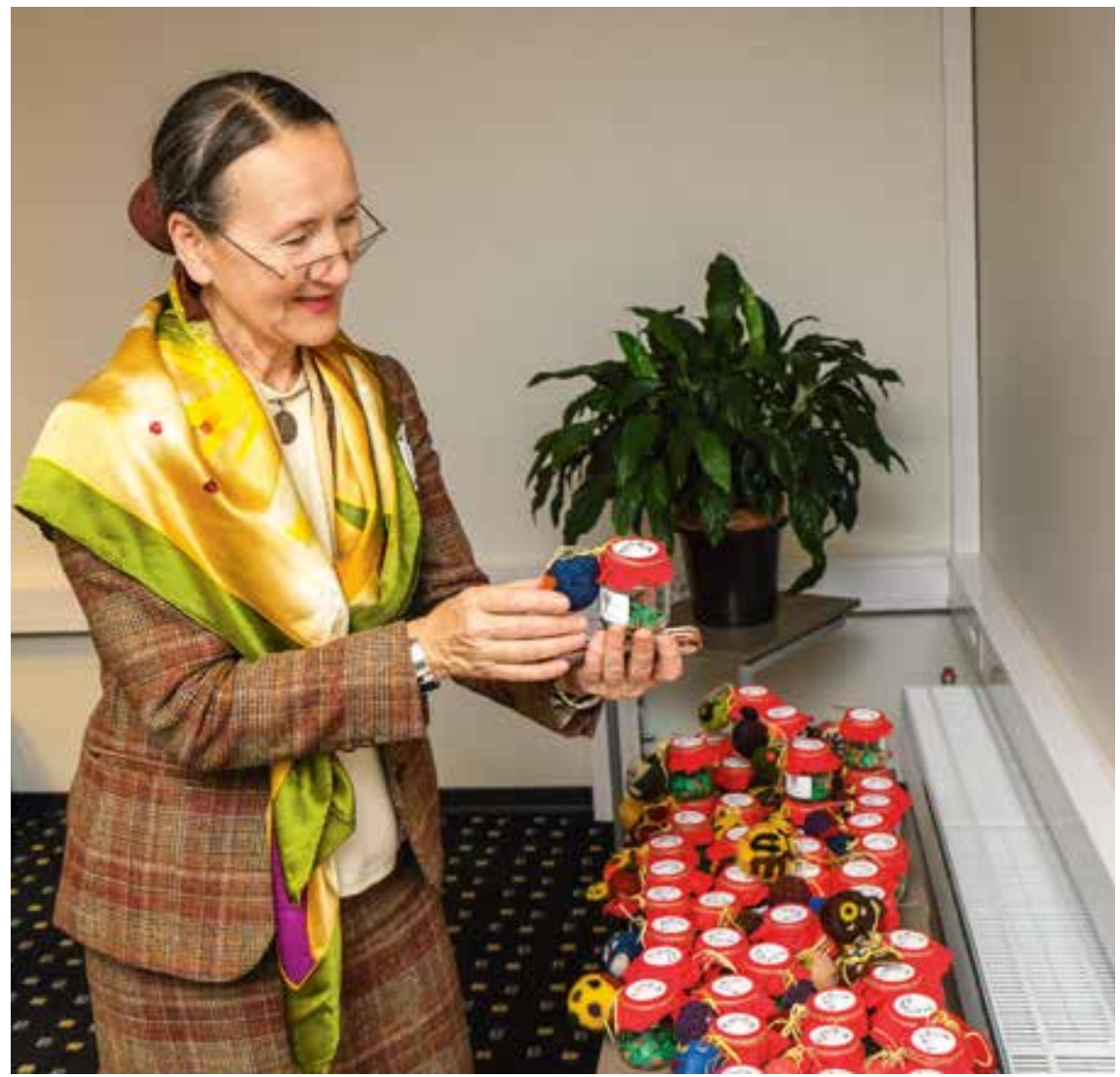

Antistresa bumbiṇas no filca, domātas bērniem ar attīstības traucējumiem, papildinātas ar saritinātām citātu lapiņām no Bībeles. Izgatavotas mikroprojekta ietvaros Harkujervē (Harkujärve), Igaunijā. Foto: Urmass Ross (Urmas Roos) 


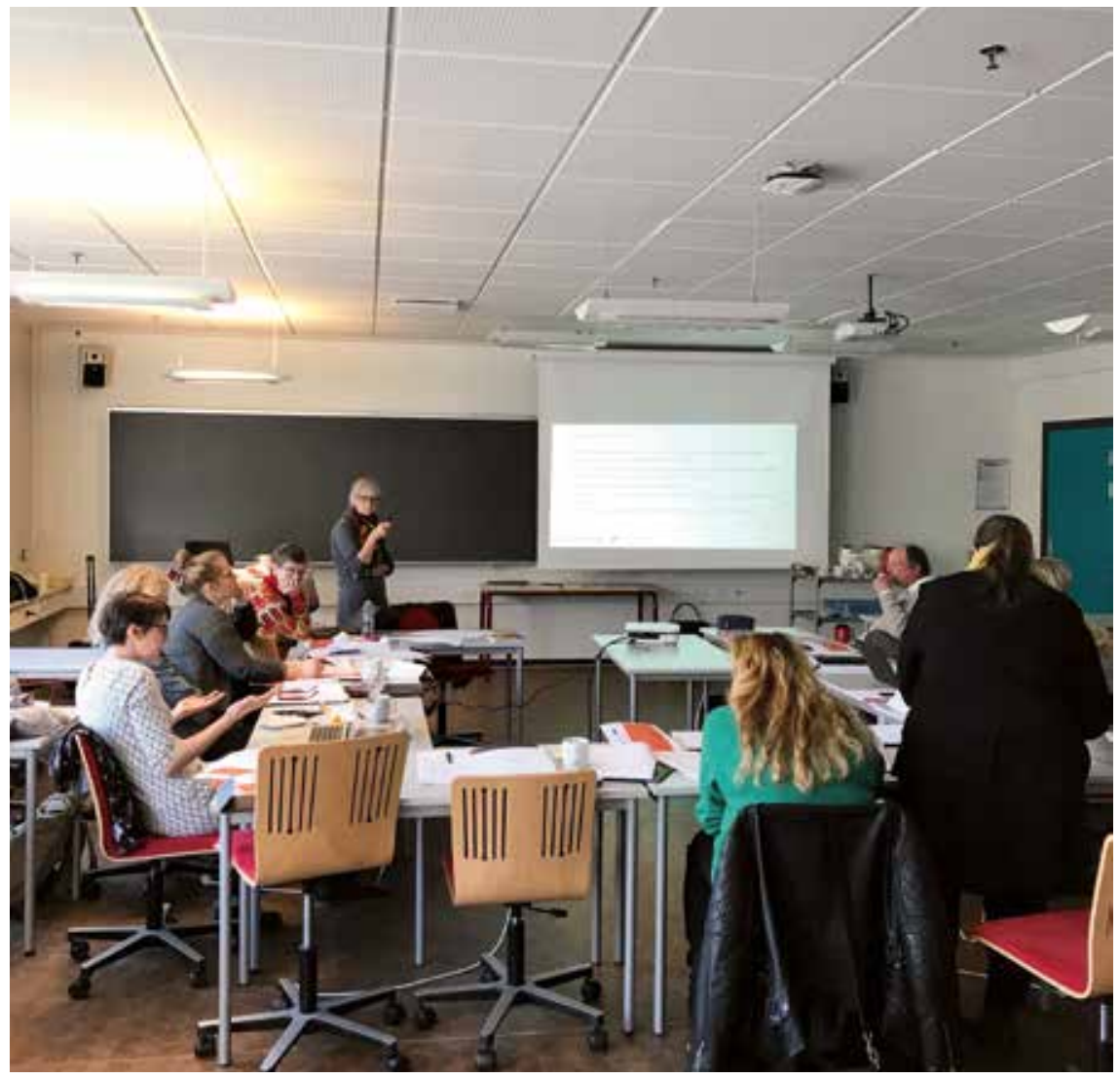

Seminārā par mācībām rīcībā 2017. gada 27. februārī Esbjergā. Foto: Anna Stepčenko 


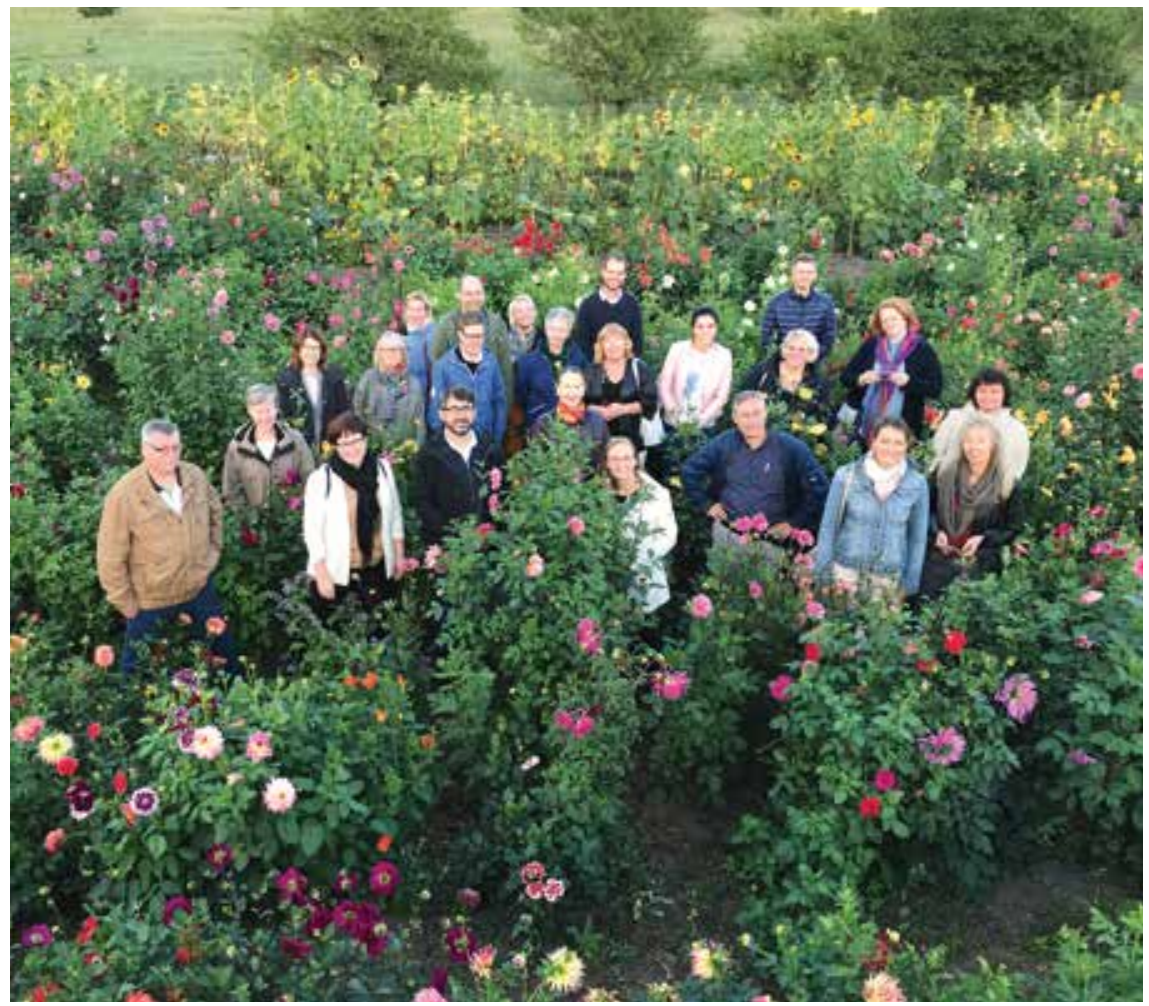

SEMPRE projekta sapulces dalībnieki izbraukumā Grobiņā Andra Leimanta veidotā dāliju dārzā "Purvičos" 2018. gada 13. septembrī. Foto: Anna Stepčenko 

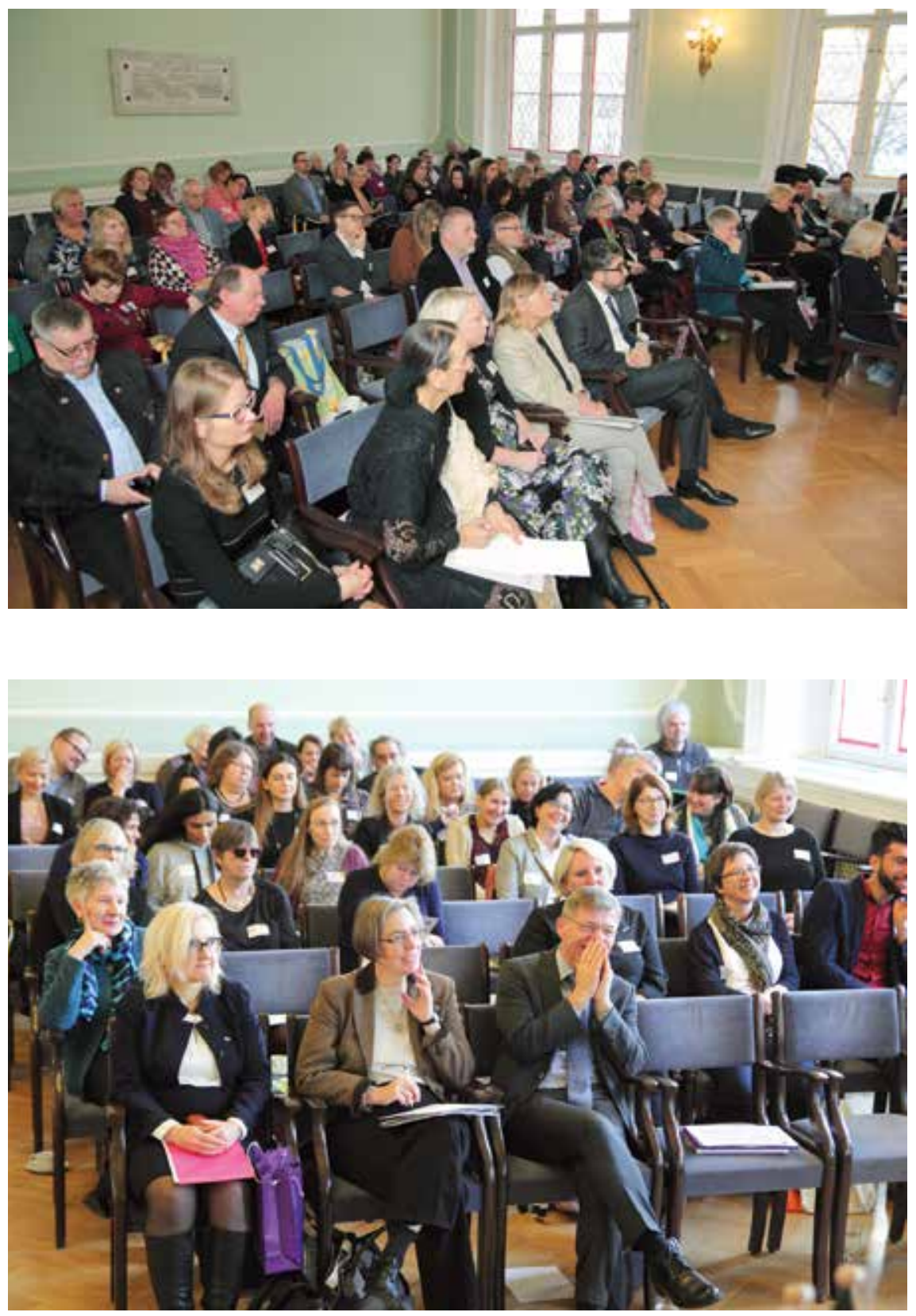

Starptautiskā projekta "Sociālā spēcināšana regீionos" (SEMPRE) noslēguma konferences dalībnieki 2018. gada 27. novembrī Latvijas Universitātes Mazajā aulā. Foto: Toms Grīnbergs 


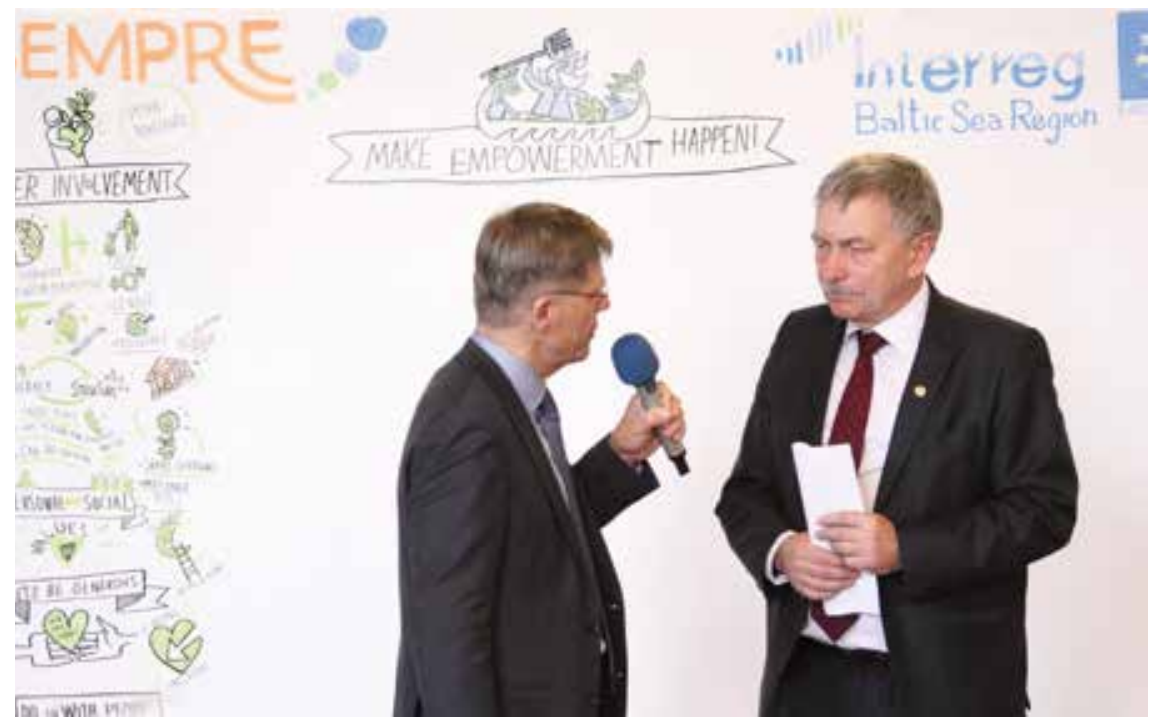

Starptautiskā projekta "Sociālā spēcināšana reǵionos" (SEMPRE) noslēguma konference 2018. gada 27. novembrī. No kreisās: SEMPRE projekta vadošā partnera - Šlēsvigas-Holšteinas Diakonijas - vadītājs Heiko Nass (Heiko Naß) un Latvijas Universitātes rektors prof. Indriķis Muižnieks. Foto: Toms Grīnbergs 


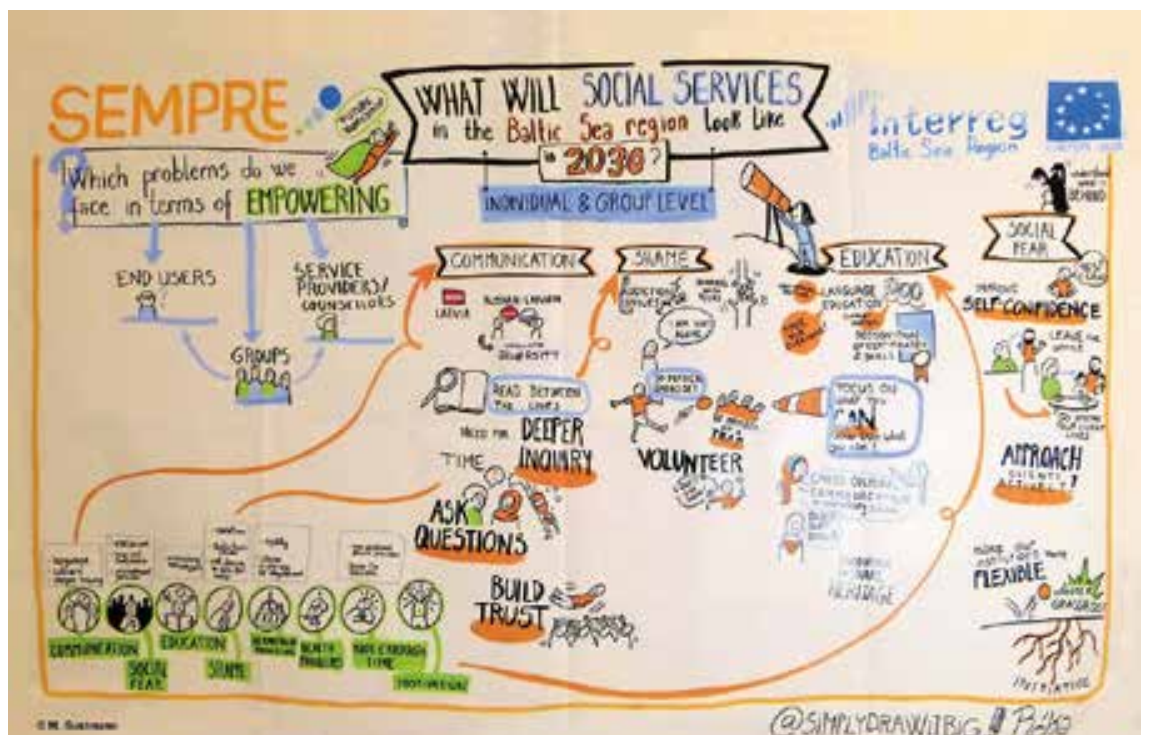

Nākotnes darbnīcas darba grupas ideju grafiskā vizualizācija noslēguma konferencē 2018. gada 27. novembrī. Foto: Mihaels Gustmans (Michael Gustmann) 

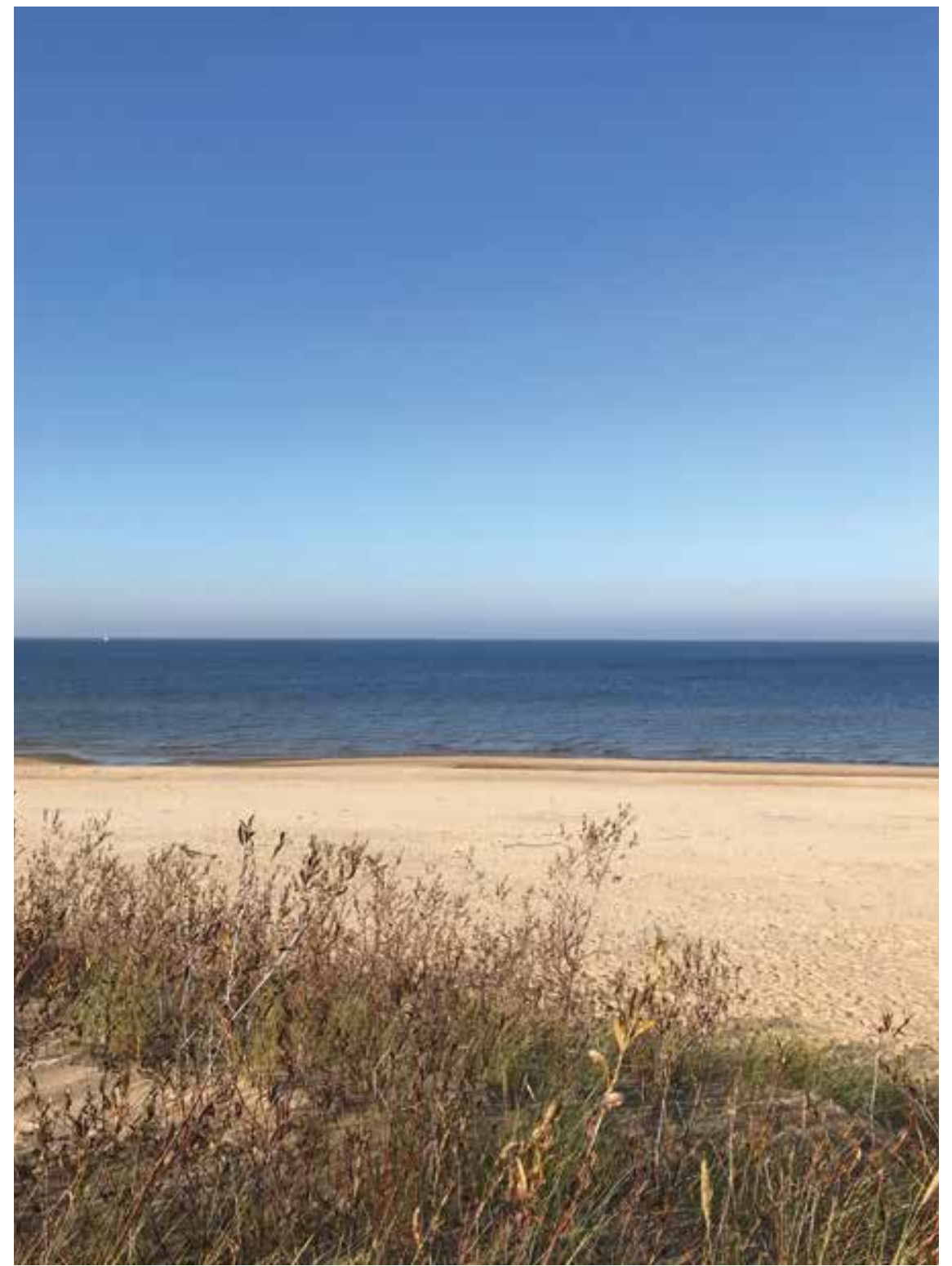

Rīgas jūras līcis, dabas parks "Piejūra”. Foto: Anna Stepčenko 
Anna Stepčenko, Laura Jaunromāne

\title{
lesaistītās/ieinteresētās puses sociālo pakalpojumu organizāciju personāla un pakalpojumu galalietotāju spēcināšanā. Teorētisks ieskats un SEMPRE projekta empīrisko datu analīze
}

\author{
Stakeholders of Social Service Provider \\ Organisation Staff and End User Empowerment. \\ Theoretical Insight and Analysis of Project \\ SEMPRE Empirical Data
}

\section{Summary}

The aim of this article is to highlight the role of the stakeholders in social empowerment process and to characterize them as a tool of empowerment.

The article contains analysis of both theoretical aspect and empirical data characterising stakeholders' participation in the local empowerment networks of the eight Baltic sea region countries. The authors have implemented a theoretical analysis of stakeholders as a concept, its development, as well as the usual framework of the stakeholders' analysis is provided. The contemporary meaning of stakeholders is explored according to R. Edward Freeman, the theorist of business management, as viewed in his book "Strategic Management: A Stakeholder Approach" (1984). It has become a landmark within fields of business and third sector. Many significant contemporary international organizations work in cooperation with their stakeholders. Those aspiring to protect general human ethical values include the United Nations Organization, World Health Organization, World Wildlife. The framework of stakeholders' analysis consists of three parts: 1 . identifying stakeholders, 2 . differentiating and categorizing stakeholders, 3 . investigating relationships between stakeholders. 
An empirical information on stakeholders of the SEMPRE project partners has been gathered at the very beginning of the project. A questionnaire was distributed among the partners. The content of the questionnaire consisted of information on status of stakeholders, their aims, resources, functions, and roles in the relevant Local Empowerment Network (LEN) and Regional Coordination Group (RCG), and, finally, their contact information.

As a result, there were received 17 completed questionnaires that contained information about 168 stakeholders. The main findings of the stakeholders' analysis of the SEMPRE project partners are being related to levels and types of stakeholders. Three levels of stakeholders were defined - those representing national, regional and local levels, as well seven types of stakeholders: 1. policy and decisions makers, 2. policy implementing stakeholders, 3. educational and research institutions, 4. professional education institutions, workshops, day care centers, 5. non-governmental organizations and their networks, 6. entrepreneurs, 7. individuals (relatives, friends).

The aims of stakeholders depend on the level and type they belong to. The classification of aims ranges from general social policy promotion to specific education, life-long learning, support, and philanthropy.

The resources at their disposal similarly depend on their level and type. They are placed in a scale including establishment of social policy, legislative regulations, impact on mass media, knowledge and experience to share, rooms and places to offer an emotional closeness for the end users.

Roles of the project SEMPRE stakeholders are divided into social policy makers, decision makers, educators, experts, consultants, researchers, analysts, leaders of opinions, supporters, involvers. Encouraging is also an important role for the end users. The most widespread functions are an exchange of knowledge, consultations, sharing experience.

Key words: stakeholders, empirical data on their aims, resources, functions, roles.

\section{Kopsavilkums}

Raksta mērķis ir teorētiski izskaidrot, ko nozīmē jēdziens "iesaistītās/ieinteresētās puses”, un analizēt empīiskos datus par SEMPRE projektā iesaistītām/ ieinteresētām pusēm. Jēdziena stakeholders, kas latviešu valodā visbiežāk tiek tulkots kā "iesaistītās puses”, saturiskā log̣ika liek tā nozìmes precizēšanai pievienot apzīmējumu "ieinteresētās puses". Tādēl šai izdevumā tiek lietots jēdziens "iesaistītās/ieinteresētās puses". Sākumā tiek sniegta jēdziena definīcija, tad aplūkotas jēdziena saturiskās nozīmes pārmaiṇas laika gaitā un tā mūsdienu saturs. Šì raksta kontekstā iesaistītās puses ir sociālās spēcināšanas aǵenti. Teorētisko ieskatu turpina projekta partneru sniegtās empīiskās informācijas analīze par iesaistītām/ieinteresētām pusēm, par šo pušu lokālo spēcināšanas tīklu sadarbību un pakalpojumu galalietotāju iesaistǐšanu sociālo pakalpojumu veidošanā. 168 uzrādīto iesaistīto/ieinteresēto pušu analīzes 
rezultātā ir radīta tipolog̣ija, ko veido septiņi iesaistīto/ieinteresēto pušu tipi. Ir analizēti iesaistīto/ieinteresēto pušu mērḳi, resursi un lomas sociālās spēcināšanas procesā.

Atslēgvārdi: iesaistītās/ieinteresētās puses - jēdziena definīcija, saturs un attīstība, empīriskie dati par iesaistīto pušu tipiem, funkcijām, mērķiem, resursiem un lomām.

Tematika. Jēdziena “iesaistītās/ieinteresētās puses” saturs, iesaistīto/ieinteresēto pušu analīzes struktūra. Sociālās spēcināšanas jēdziens iesaistīto/ieinteresēto pušu kontekstā. Empīrisko datu par SEMPRE partneru iesaistītām/ ieinteresētām pusēm analīze. Iesaistīto/ieinteresēto pušu varas kapitāla un darbības līmeṇa raksturojums. Iesaistīto/ieinteresēto pušu mērķu raksturojums. Iesaistīto/ieinteresēto pušu tipologija, resursi un lomas.

\section{Jēdziena "iesaistītās/ieinteresētās puses" saturs}

Šì iztirzājuma centrālais jēdziens un temats ir "iesaistītās/ieinteresētās puses”. Ar šo jēdzienu Rietumu autori vadīšanas teorijā un pārvaldības praksē apzīmē visu to dažkārt l̦oti plašo grupu, institūciju un arī indivīdu kopumu, tai skaitā lobiju, kas kaut kādā mērā ir iesaistīts, iesaistījies un/vai ieinteresēts notikumu vai kāda procesa gaitā, lai to ietekmētu sev vēlamā virzienā. Iesaistīto/ieinteresēto pušu mērḳis var būt arī iegūt zināšanas, kā dažādi masu vai grupu ietekmēšanas līdzekḷi ietekmē grupu apziņu, uzvedību un rīcību.

Vārds stakeholder angḷu valodā ir saliktenis, kas cēlies no vārdiem stake un holder. Abiem vārdiem, kā tas bieži mēdz būt angḷu valodā, ir daudzas un visai atšķirīgas nozīmes, un vārda viena un tā pati forma var būt gan lietvārds, gan darbības vārds. Vārds stake var tikt tulkots kā "stabs", "miets", "atbalstìt ar stabu/mietu" vai arī kā "likme kāršu spēlē", "likt uz spēles". Vārds holder var tikt tulkots kā "tvēriens", “ietekme”, "pakḷaut ietekmei”, "pārvaldìt”, "būt īpašniekam”, "izturēt”, "atturēt", "vadīt sapulci" u. c. Sākotnēji ar vārdu stakeholder ir saukts, apzīmēts cilvēks, kas liek likmes kāršu spēlē vai derībās. Vēlāk ar vārdu stakeholder sākts apzīmēt akciju vai paju ìpašnieku uzṇēmējdarbībā. Mūsdienās uzņēmējdarbības un citu sektoru vadīšanā ar jēdzienu stakeholder apzīmē visus, kas ir ieinteresēti un iesaistīti kādā notikumā un/vai norisē un mègina to ietekmēt. Iesaistìtie/ieinteresētie var būt visu līmeṇu institūcijas, organizācijas un/vai indivīdi. Iesaistītie var 
būt ieinteresēti norisi ārēji un iekšèji veicināt un atbalstìt, kā arī kavēt, likt šḳēršlus, ja norise tiem nav izdevīga, tātad neatbilst šo darbojošos aktoru interesēm. Latviešu valodā jēdziens stakeholder tiek tulkots dažādi. To tulko kā 1) "iesaistītās puses", 2) "ieinteresētās puses", 3) "norisē iesaistījušies aktori” (anglu val. actors), 4) vēl cits veids, kā mēdz dēvēt iesaistijjušās institūcijas, organizācijas, sociālās grupas un/ vai indivīdus, ir "iesaistītās/ieinteresētās aǵentu grupas" - tā jēdzienu stakeholder savā promocijas darbā tulkojusi Viola Korpa $(2012,65)$ un vēlāk pati to atzinusi par "diezgan smagnēju apzīmējumu". Tādēḷ, lai saprastu konkrētam gadījumam atbilstošāko jēedziena nozīmi, ir jāpārzina tematiskais lauks un jāzina konteksts, kurā jēdziens tiek lietots. Šai rakstā atbilstoši temata saturam lietosim jēdzienu "iesaistītās/ieinteresētās puses" kā jēdziena stakeholder saturam atbilstošāko atveidojumu latviešu valodā.

\section{Iesaistīto/ieinteresēto pušu analīzes struktūra}

Iesaistìto/ieinteresēto pušu analīze vadīšanas jomā ir plaši izmantota metode, ko sāka lietot 19. gadsimtā biznesa vidē. Vēl plašāk to sāka izmantot uzṇēmējdarbībā 20. gadsimta 30. gados, lai uzlabotu attiecības ar sabiedrību un palielinātu uzṇēmēju peḷnu. Sākotnēji iesaistītās puses tika apzīmētas arī ar jēdzienu shareholders vai stockholders. Šai gadījumā šo vārdu saturs ir tiešs un skaidrs. Tas ir šaurs grupējums, tātad biznesa uzṇēmuma īpašnieku grupas jeb daḷu turētāji, kuri piedalās biržu spekulācijās un kuru galvenās, ja ne vienīgās intereses ir gūt peḷnu. 60. gadu beigās transnacionālās uzṇēmumu kompānijas ievieš jēdzienu stakeholders, jo vairākas universālas transnacionālas un pārnacionālas organizācijas, jo īpaši Apvienoto Nāciju Organizācija, iestājas par universālām cilvēciskām tiesībām un vērtībām, pārredz un prognozē attīstības tendences. Tādēl tās paplašina vērtîbu izpratni, iesaka ieviest normatīvu kontroli pār uzṇēmējdarbību, radot korporatīvās sociālās atbildības jēdzienu un lietojot jaunu pieeju uzṇēmējdarbības regulēšanai. Tādējādi tiek būtiski paplašināts ieinteresēto pušu loks. Korporatīvā sociālā atbildība nozīmē pel̦nas intereses sasaistīt ar dabas vides piesārņošanas ierobežošanu un ņemt vērā sabiedrības intereses, jo abas šìs vides - dabas vide un sociālā vide (galvenokārt 
algotais darbaspēks un tā atalgojuma līmenis) - ir pamatresursi un galvenie avoti, kas rada peḷnu. Pel̦nas gūšanu kā vienīgo vai galveno uzṇēmējdarbỉbas motīvu ierobežo uznēēmēju rīcību regulējošas normas likumdošanā, ètiska standarta regulas un starptautiskas normas. Tādējādi būtiski paplašinās rīcību regulējošais ietvars un iesaistīto/ ieinteresēto pušu skaits. Amerikāṇu biznesa administrēšanas teorētikis Roberts Edvards Frīmens (Freeman, 2010) apraksta un analizē jēdziena "iesaistītās puses" izcelsmi un attīstību.

R. E. Frīmens lieto jaunu pieeju iesaistìto/ieinteresēto pušu analīzei un ievērojami paplašina šauro iesaistīto/ieinteresēto uzņēmuma ipašnieku loku. Iesaistìto/ieinteresēto pušu korpusā ražošanas sfērā tagad ir iekḷautas valdības iestādes, politiskās partijas, uzṇēmējdarbības asociācijas, arodbiedrības, iedzīvotāju kopienas, finansisti/investori, piegādātāji, darba devēji, darba n̦ēmèji, patērētāji un arī konkurenti.

Frīmens definē jēdzienu "iesaistītās/ieinteresētās puses" kā grupas un indivīdus, kuri tiek ietekmēti un paši ietekmē konkrētus procesus. Iesaistìtās/ieinteresētās puses tātad ir jebkuras identificējamas personu grupas un viṇu pārstāvētās institūcijas, kas ietekmē uzṇēmuma izdzīvošanu un nākotni. Tāda ir vienkāršā definīcija, kas issā formā izsaka lietas būtību.

20. gadsimta 80. gados kā stratēgiskās vadī̌̌anas pieeja tiek izstrādāta iesaistīto/ieinteresēto pušu teorija, kas attīstās joprojām, jo tai pievēršas aizvien vairāk autoru un praktiskās lietojamības dẹl tā kḷūst populāra visās nozīmīgākajās darbības sfērās, kur jāpieṇem lēmumi par attīstîbas plāniem un rīcību, lai tos īstenotu. Tātad iesaistīto/ieinteresēto pušu matricas kā universālu situācijas analīzes instrumentu ir lietderīgi lietot uzṇēmējdarbībā, sabiedrības un valsts pārvaldībā, starptautiskā politikā, sociālā politikā, veselības aprūpes politikā, jebkuras citas nozares politikā un aktivitātēs, kā arī bezpeḷnas sabiedrisko organizāciju darbībā. Daudzas nozīmīgas starptautiskas organizācijas - Apvienoto Nāciju Organizācija, Pasaules Veselības organizācija, Pasaules Dabas fonds - un starptautiskās profesionālās asociācijas lieto iesaistīto/ieinteresēto pušu analīzes metodi un ir izstrādājušas saviem mērḳiem piemērotas vadlīnijas iesaistīto/ieinteresēto pušu analīzei. Paplašinātu iesaistīto/ieinteresēto pušu jēdzienu 1996. gadā ir lietojis tālaika britu premjerministrs Tonijs Blērs (Tony Blair), aicinot veidot iesaistīto/ieinteresēto pušu ekonomiku (stakeholder economy), kurā tiktu iesaistītas visas sabiedrības grupas (Davies, 1996). 
Iesaistīto/ieinteresēto pušu teorijā tiek ieteikts iesaistītās/ieinteresētās puses analizēt noteiktā log̣iski strukturētā secībā (Reed, 2009; Gijselinckx, 2009, 4, 6). Ieteiktās secīgās darbības ir šādas:

- identificēt iesaistītās/ieinteresētās puses, tas nozìmē noteikt, kas ir iesaistîtās/ieinteresētās puses un ko tās dod;

- tipolog̣izēt jeb klasificēt iesaistītās/ieinteresētās puses, tas nozìmē sadalìt tās dažādos tipos saskaṇā ar to varas pilnvarojumu;

- noteikt un izprast iesaistīto/ieinteresēto pušu mijiedarbỉbu un savstarpējās attiecības.

Lai identificētu iesaistītās/ieinteresētās puses, var izmantot dažādas metodes. Tās var būt fokusgrupu intervijas, daļeji strukturētas intervijas, sniega bumbas metode, eksperta analīze. Kad iesaistītās/ieinteresētās puses ir identificētas, iespējams veidot to tipologiju un savstarpējo attiecību karti pēc to vietas varas hierarhijā un tām esošā varas resursa, pēc to racionalitātes līmeņa vai egocentriskām pretenzijām un spējas raisìt dialogu, kā arī pēc kritiskuma, iztirzājot iesaistīto/ieinteresēto pušu intereses, lomu lēmumu pien̦emšanā un nozīmīgumu saikṇu un attiecību veidošanā. Īsumā tas viss nozīmē ietekmēšanas un ietekmes potenciāla izvērtēšanu. Veidojot iesaistīto/ieinteresēto pušu tipoloǵiju, var izmantot analītisko pieeju, izkārtojot iesaistītās/ieinteresētās puses hierarhiskā kārtībā pēc to funkcijām un varas resursa, lomām politikas veidošanā un lēmumu pieņemšanā. Iesaistīto/ieinteresēto pušu savstarpējo attiecību noskaidrošanā var veidot un lietot mijiedarbības matricas, izmantot zināšanu kartēšanu, sociālā tīkla analīzi.

Konkrēta iesaistīto/ieinteresēto pušu apzināšana un analīze ir veikta SEMPRE projektā. Eiropas Savienības Interreg Baltijas jūras regiiona valstu programmas SEMPRE projekta pamatmērḳis ir sociālo pakalpojumu organizāciju personāla un sociālo pakalpojumu galalietotāju sociālā spēcināšana. Lai šo mērḳi sasniegtu, ir apzinātas sociālo pakalpojumu lietotāju vajadzības un izzinātas barjeras un šḳēršlıi sociālo pakalpojumu sniegšanas organizāciju darbā. Pēc iegūtās informācijas apkopošanas lokālie spēcināšanas tīkli mikroprojektu veidā pārbaudīja praksē instrumentus, pieejas, metodes, lai pārliecinātos par to, vai organizācijas, kas sniedz sociālos pakalpojumus, regionos kḷūst spēcīgākas un varētu sociāli spēcināt sociālo pakalpojumu saṇēmējus jeb lietotājus. Sākot īstenot projektu, viens no pirmajiem darbiem bija iegūt informāciju par tās vietas, kur darbojas lokālais spēcināšanas tīkls, 
sociālekonomisko kontekstu, kā arī par iesaistītām/ieinteresētām pusēm jeb aktoriem, kas ietekmē darbu ar konkrēto sociālo pakalpojumu lietotāju grupu (tās bija izvēlētas vairākas un dažādas), kā arī analizēt iesaistītās/ieinteresētās puses. Iesaistīto/ieinteresēto pušu analīze šai projektā ir vajadzīga saistībā ar tā pamatmērḳi - spēcināt sociālo pakalpojumu sniedzējus, kas varētu isstenot spēcināšanas ideju, iesaistot savas dzīves kvalitātes uzlabošanā sociālo pakalpojumu galalietotājus.

\section{Sociālās spēcināšanas jēdziens iesaistīto/ieinteresēto pušu kontekstā}

Sociālās spēcināšanas jēdziens ir attīstìts tajā pašā laikā, kad radās iesaistīto pušu jēdziena mūsdienu izpratne. Tas nonāca sarunu tematu, diskursu un sociālo protesta akciju apritē pagājušā gadsimta 60. gadu beigās. Vēlāk tas kḷuva par plaši lietotu jēdzienu, kas ietver ideju, ka tiesības uz varu ir arī vājām, mazāk aizsargātām sociālām grupām un ka tās var ietekmēt varas lēmumus. Tā kā stratificētā sabiedrībā sociālo grupu intereses ir l̦oti atšķirīgas, tad varas lēmumu ietekmēšanai ir izveidota pat speciāla oficiāli atzīta institūcija, saukta par lobēšanu, lobiju. Leg̣itimitāti ieguva ideja par nepieciešamību notikumos un norisēs un to apspriešanā iesaistīt vājās, viegli ievainojamās, maz aizsargātās sociālās grupas, jo īpaši tad, kad lēmumi varas institūcijās ietekmē vinu dzīves apstākḷus. Arī šĩs sociāli vājās grupas tāpat kā ekonomiski spēcīgās sociālās grupas var pārstāvēt lobijs.

\section{Iesaistīto/ieinteresēto pušu empīrisku datu analīze}

2016. gada aprīlì SEMPRE projekta partneri tika lūgti identificèt iesaistītās puses, kas ietekmē sociālo pakalpojumu piedāvājumu galalietotājiem, un aizpildīt tiem izsūtīto anketu, lai partneru datus varētu apkopot. Anketā tika iekḷautas šādas informatīvas sadaļas: 1) iesaistìtās/ieinteresētās puses nosaukums; 2) îss apraksts par to, ar ko tā nodarbojas; 3) iesaistītās/ieinteresētās puses mērḳis vai intereses par SEMPRE partneri; 4) kādus resursus iesaistītās/ieinteresētās puses spēj 
Tabula

Projekta partneru atrašanās vieta, galalietotāji un iesaistīto pušu skaits

\begin{tabular}{|c|c|c|c|}
\hline $\begin{array}{l}\text { Projekta } \\
\text { partnera } \\
\text { Nr. }\end{array}$ & $\begin{array}{c}\text { Vieta, kur darbojas vietējais } \\
\text { spēcināšanas tīkls vai regionionālā } \\
\text { koordinācijas grupa }\end{array}$ & $\begin{array}{l}\text { Sociālo pakalpojumu } \\
\text { galalietotāju kategorijas }\end{array}$ & $\begin{array}{l}\text { lesaistīto/ } \\
\text { ieinteresēto } \\
\text { pušu skaits }\end{array}$ \\
\hline 1. & $\begin{array}{l}\text { Ditmāršene (Dithmarschen), } \\
\text { Vācija }\end{array}$ & Viena vecāka g̊imenes & 12 \\
\hline 2. & Plēne (Plön), Vācija & $\begin{array}{l}\text { Ilgtermina bezdarbnieki, } \\
\text { kam ir gُ gimene }\end{array}$ & 8 \\
\hline 3. & $\begin{array}{l}\text { Ziemelffrīzlande } \\
\text { (Nordfriesland), Vācija }\end{array}$ & Bēgli un imigranti & 10 \\
\hline 4. & $\begin{array}{l}\text { Esterbotena (Österbotten), } \\
\text { Somija }\end{array}$ & $\begin{array}{l}\text { Vecāka gadagājuma } \\
\text { personas }\end{array}$ & 7 \\
\hline 5. & $\begin{array}{l}\text { Kokola (Kokkola) un Pietarsāri } \\
\text { (Pietarsaari), Somija }\end{array}$ & $\begin{array}{l}\text { Migranti, kas ir } \\
\text { ilgtermiņa bezdarbnieki }\end{array}$ & 6 \\
\hline 6. & - & - & \\
\hline 7. & $\begin{array}{l}\text { Grobin̦a, Bārta, Dubeñi, } \\
\text { Rucava, Durbe, Liepāja. } \\
\text { Kurzemes reǵions, Latvija }\end{array}$ & $\begin{array}{l}\text { Pieaugušas personas ar } \\
\text { invaliditāti }\end{array}$ & 27 \\
\hline 8. & - & - & \\
\hline 9.1. & Jurbarka (Jurbarkas), Lietuva & Viena vecāka giimenes & 3 \\
\hline 9.2. & Pageēgii (Pagègiai), Lietuva & Vielatkarīgās personas & 4 \\
\hline 10.1 & $\begin{array}{l}\text { Harkujerve (Harkujärve), } \\
\text { Igaunija }\end{array}$ & $\begin{array}{l}\text { G̦imenes ar bērniem. } \\
\text { No ieslodzijjuma } \\
\text { atbrīvotas personas }\end{array}$ & 14 \\
\hline 10.2 & $\begin{array}{l}\text { Austrumviru aprinkkis (Ida- } \\
\text { Virumaa), Igaunija }\end{array}$ & $\begin{array}{l}\text { Ģimenes un personas ar } \\
\text { invaliditāti }\end{array}$ & 15 \\
\hline 11.1. & $\begin{array}{l}\text { Veru apriņķis (Võrumaa), } \\
\text { Igaunija }\end{array}$ & Ģimenes ar bērniem & 14 \\
\hline 11.2 & $\begin{array}{l}\text { Pelvas apriņķis (Põlvamaa), } \\
\text { Igaunija }\end{array}$ & Ģimenes ar bērniem & 6 \\
\hline 12. & Ričivola (Ryczywót), Polija & Jaunieši & 5 \\
\hline 13. & $\begin{array}{l}\text { Norbotena (Norrbotten), } \\
\text { Zviedrija }\end{array}$ & $\begin{array}{l}\text { Jaunieši bez darba } \\
\text { ar zemu, nepabeigtu } \\
\text { izglītību }\end{array}$ & 7 \\
\hline 14. & $\begin{array}{l}\text { Ėvertornjo (Övertorneå), } \\
\text { Zviedrija }\end{array}$ & $\begin{array}{l}\text { Migranti, kas iecel̦ojuši } \\
\text { nesen un kam nav } \\
\text { uzturēšanās aț̣auju }\end{array}$ & 9 \\
\hline 15. & $\begin{array}{l}\text { Tendere (Tønder) un Varde } \\
\text { (Varde), Senderjitlande } \\
\text { (Sønderjylland), Dānija }\end{array}$ & Bēgli & $5+4$ \\
\hline 16. & - & & \\
\hline 17. & Vidzemes regions, Latvija & $\begin{array}{l}\text { Jaunieši ar zemu } \\
\text { izglītību, bez prasmēm } \\
\text { un darba }\end{array}$ & 12 \\
\hline
\end{tabular}


piedāvāt; 5) kāda ir to loma - ko tās spēj izdarīt lokālā un reǵionālā tîkla spēcināšanā; 6) kontaktinformācija.

No partneriem tika saņemtas 17 aizpildìtas anketas. Aizpildìto anketu sarakstos iesaistīto pušu skaits bija no trīs (PP9 - 9. projekta partneris) līdz 27 (PP7). Kopējais iesūtīto iesaistīto/ieinteresēto pušu skaits ir 168. Daži projekta partneri strādā ar vairāk nekā vienu pakalpojumu galalietotāju grupu vai vairāk nekā vienā reǵionā, tāpēc trijos gadījumos partneri ir iesūtījuši divus sarakstus.

Dati par projekta partneru atrašanās vietu, vinu galalietotāju grupām un iesaistītām/ieinteresētām pusēm, kurām ir lokālās spēcināšanas tìkli, ir apkopoti tabulā.

Iesaistīto/ieinteresēto pušu empīrisko datu analīze ir veikta divējādi - vispārīgi un konkrēti. Vispārīgi tiek raksturots iesaistīto/ ieinteresēto pušu tipoloğiskais iedalījums pēc darbības mēroga, līmeņa, varas kapitāla un mērḳiem. Resursu piedāvājums un lomu raksturojums tiek piesaistīts konkrētam iesaistìto/ieinteresēto pušu tipam.

\section{Iesaistīto/ieinteresēto pušu varas kapitāla un darbības līmeņa raksturojums}

Iesaistītās/ieinteresētās puses pēc to funkcionēšanas mēroga, varas un ietekmes var iedalìt trīs līmeños:

1) valsts jeb nacionālā līmeṇa iesaistītās/ieinteresētās puses;

2) regionālā līmeṇa iesaistītās/ieinteresētās puses;

3) vietējā līmeṇa iesaistītās/ieinteresētās puses.

Šie līmeṇi norāda uz kontekstu, kādā iesaistītās/ieinteresētās puses darbojas, tomēr tie ne vienmēr ir nozīmīguma vai svarīguma rādītāji. Empīrisko datu analīzes rezultātā ir izveidota iesaistīto/ieinteresēto pušu tipologiija, kas sastāv no septiniem tipiem. Tie ir:

1) lēmumu pieṇēmēji, politikas veidotāji;

2) politikas ìstenotāji;

3) izglìtības un pētniecības institūcijas;

4) darbnīcas, radošie centri, dienas centri;

5) nevalstiskās organizācijas un to sadarbības tīkli;

6) uzñēmèji;

7) individuālas personas. 
Analīzes procesā atsevišķas iesaistītās/ieinteresētās puses ir atzīmētas kā piederīgas pie diviem tipiem, tomēr lielākoties katra iesaistìtā/ieinteresētā puse ir tipolog̣izēta atbilstoši tās galvenajai funkcijai. Acīmredzams izṇēmums ir pašvaldības, kas ir gan nacionālās, gan lokālās politikas realizētājas.

Nacionālā līmeņa iesaistītās/ieinteresētās puses ir dažādas ministrijas, valsts komisijas, organizācijas un ağentūras, piemēram, nodarbinātības aǵentūras un integrācijas fondi, šo organizāciju reǵionālie biroji, piemēram, Nodarbinātības valsts dienesta birojs pašvaldībā var būt attiecināms uz regionāla vai vietēja līmeņa iesaistīto pušu partnerību. Regionu vai pašvaldību domes un sociālie dienesti atkarībā no valsts administratīvā iedalījuma un pārvaldes organizācijas attiecināmi uz reg̣ionālo vai vietējo līmeni. Nevalstiskās organizācijas un uzṇēmumi var darboties visos trijos līmeṇos, tāpat arī izglìtības institūcijas, piemēram, vietējā skola un nacionāla mēroga universitāte. Darbnīcas, vietējo kopienu organizācijas un apvienības, indivīdi strādā kā vietējā līmeņa iesaistītās/ieinteresētās puses. Dažādie līmeṇi norāda uz mēroga kontekstu, kādā iesaistītās/ieinteresētās puses visbiežāk darbojas.

Kopumā partneru iesūtītajos sarakstos tika identificētas 33 nacionālā līmeņa iesaistītās/ieinteresētās puses, 38 reǵionālā līmeņa iesaistītās/ieinteresētās puses (tajā skaitā viena gan nacionālajā, gan reǵionālajā līmenī un astoņas gan reǵionālajā, gan vietējā līmenī) un 106 vietêjā līmeṇa iesaistītās/ieinteresētās puses. Tā kā projekts ir orientēts uz vietējā līmeņa sadarbỉbas tỉkla veidošanu un mikroprojektu izveidi, tad vietējā līmeṇa iesaistītās/ieinteresētās puses partneru sarakstos dominē.

Reǵionālais un vietējais līmenis dažkārt var būt grūti nodalāms, tas atkarīgs no pārvaldes sistēmas un administratīvā iedalījuma, kas dažādās valstīs atšķiras. Vācijā katrai federālajai zemei ir sava federālā valdība ar tai atbilstošām funkcijām, piemēram, Šlēsvigas-Holšteinas Sociālo lietu, veselības, zinātnes un vienlīdzības ministrija (SchleswigHolstein Ministry for Social Affairs, Health, Science and Equality) ir reǵionālā līmeṇa iesaistītā/ieinteresētā puse. Latvijā nākamais pārvaldes līmenis pèc valsts līmeņa ir vietējā līmeņa pašvaldības, piemēram, Grobiṇas, Priekules un Rucavas novada pašvaldības, kas atrodas Kurzemes reǵionā, kurš ir klasificēts kā statistikas reǵions, bet tam nav pārvaldības statusa. Visos trijos iesaistīto/ieinteresēto pušu līmeņos tiek veidota politika, pieņemti lēmumi un sadalīti un pārdalīti līdzekḷi. 


\section{6. lesaistīto/ieinteresēto pušu mērķu raksturojums}

Nacionālā līmeņa iesaistītām/ieinteresētām pusēm mērḳi ir vispārīgāki. Valsts ministrijas par savu misiju uzskata iedzīvotāju dzīves apstākḷu uzlabošanu tajās jomās, kas ir to pārvaldībā. Ministriju pakḷautībā esošās valsts aǵentūras îsteno ministriju izvirzìto mērḳu sasniegšanu. Piemēram, Vaivaru Tehnisko palīglīdzekḷu centra mērḳis ir nodrošināt tehnisko palīglīdzekḷu pakalpojumus atbilstoši valsts finansētajām kvotām personām ar invaliditāti. Domājot par sadarbību ar šo iesaistìto/ieinteresēto pusi, projekta vadìtājam jāṇem vērā, ka šìs organizācijas resursi nevar tikt izlietoti tikai vietējā līmenī, tai jānodrošina pakalpojumi visiem tiem valsts iedzīvotājiem, kam tie ir nepieciešami. Tajā pašā laikā valsts aǵentūru reǵionālajiem birojiem ir izvirzìti mērḳi tieši zemāka līmeņa administratīvām vienībām. Piemēram, Vācijas Federālai nodarbinātības ag̣entūrai reǵionālie biroji ir četrās apdzīvotās vietās (Job Centers Nordfriesland in Sylt, Wyk of Fohr, Husum, Breklum, Tonning, Leck and Niebull). Iesaistīto/ieinteresēto pušu vadībā ir būtiski saprast organizāciju hierarhiju un varas sadalījumu, kā arī atrast un izcelt kopīgos projekta un attiecīgās organizācijas mērḳus.

Izglìtības institūciju mērḳi var būt, piemēram, "atbalstìt ilgtspējīgu lauku regiionu attīstību” (to veic Šlēsvigas-Holšteinas federālās zemes lauku teritoriju akadēmija (Akademie für die ländlichen Räume Schleswig-Holsteins e. V.) vai "mācīt bēglus" (Dānijas Sprogskole). Universitāšu un pētniecības centru mērḳi var būt sasniedzami starptautiskā, nacionālā, reg̣ionālā līmenī. Bet pamatskolas mērḳis nodrošināt "izglìtības pieejamību un kvalitāti” (kā to Igaunijā definē iesaistītā/ ieinteresētā puse - Harkujärve Põhikool) attiecināms uz vietējo līmeni. Lai arī izglîtības un pētniecības institūciju mērḳi var būt definēti ḷoti vispārīgi, kā "izglìtība un pētniecība" (piemēram, iesaistītās/ieinteresētās puses Luleå tekniska universitet un Syddansk Universitet), tās var sniegt atbalstu projektam vairākos nozīmīgos jautājumos - pētījumos, konsultācijās, tēmas aktualizēšanā un diskusijas veidošanā.

Darbnīcas, radošie centri, dienas centri par savu mērḳi izvirza dažādas "mūžizglìtības aktivitātes" un lielākoties darbojas vietējā līmenī, jo viena no šādu centru būtiskajām priekšrocībām ir ērta piekḷuve, tuvums dzivesvietai.

Nevalstiskās organizācijas un uzṇēmēji savus mērḳus var attiecināt uz visiem trim iesaistīto/ieinteresēto pušu līmeņiem. Nevalstisko 
organizāciju mērḳi parasti ir domāti kādas nelabvēlīgā situācijā esošas sociālas grupas interešu pārstāvībai, piemēram, "veicināt vājredzīgu un neredzīgu cilvēku integrāciju sabiedrībā, vinu interešu aizstāvību un dzīves kvalitātes celšanu" (Liepājas Neredzīgo biedrība), "gimene kā labākā vide, kur bērnam uzaugt” (Igaunijas NVO Igale Lapsele Pere), "uzlabot dzīves apstākḷus lauku reǵionos, veicināt izglìīibu un apmācību, it īpaši sievietēm lauku reǵionos" (Vācijas NVO LandFrauenVerband Schleswig-Holstein e. V.), "palīdzēt veicināt gados jaunu migrantu nodarbinātību” (Somijas NVO Ehjä Ry).

Baznīcas organizāciju, it īpaši diakoniju, mērḳi ir saistīti ar kalpošanas misiju un vērsti uz līdzcilvēku atbalstīšanu. Tie ir definēti daudzējādi: "marginalizētu cilvēku spēcināšana, piedāvājot sociālos pakalpojumus lauku reǵionos (Vācijas NVO Diakonie Plön-Segeberg), "veidot dzīvošanai cienīgu vidi" (Vācijas NVO Ortskirchen) vai "baznīcas atbalsts gimenēm un indivīdiem, kas nonākuši krīzē vai nedrošā situācijā" (Igaunijas NVO EELK Diakoonia - ja ühiskonnatöö talitusel).

Uzṇēmējdarbības mērḳis ir pel̦na, tomēr tas neizslēdz dažādi motivētu gribu iesaistīties aktivitātēs sociālās atbildības jomā vai labdarības pasākumos. Tāpat arī praktiska nepieciešamība pēc darbaspēka var būt viens no iemesliem, kāpēc uzṇēmējam ir interese iesaistīties kādā spēcināšanas projektā. Eiropas Savienības valstu nodokḷu likumdošana parasti atbalsta sociālo atbildību, kā arī ziedojumu vākšanu. Tāpat arī tāds uzṇēmējdarbības veids kā sociālā uzṇēmējdarbība veicina "nodarbinātību un nodarbinātības iespējas" iedzīvotāju grupām nelabvēlīgā situācijā. Strādājot ar iesaistītām/ieinteresētām pusēm, kas ir uzṇēmēji, būtiski ir atrast to projekta aspektu, kas sniegtu labumu vinu biznesam. Tomēr sociālā atbildība var būt arī pašu uzṇēmēju mērḳis, piemēram, "profesionāla attīstība, filantropija" (Igaunijā uzṇēmums OÜ Garden).

\section{7. lesaistīto/ieinteresēto pušu tipologija, resursi un lomas}

Analizējot partneru datus, kopumā tika identificēti septiņi iesaistìto/ieinteresēto pušu tipi, taču katra partnera sarakstā nebūt nebija iekḷauti visi iesaistīto/ieinteresēto pušu tipi. Iesaistīto/ieinteresēto pušu identificēšana lauj noteikt to lomu un to rīcībā esošos resursus. 
Tādējādi projekta partneriem ir vieglāk orientēties, kur tiem meklējami vajadzīgie resursi un palīgi.

Turpmāk ir sniegta projekta partneru informācija par viṇu iesaistītām/ieinteresētām pusēm to tipolog̣ijas secībā un saistībā ar šo aktoru resursiem un lomām.

1. Sociālās politikas veidotāju (ministriju, pašvaldību) resursi un lomas.

Sociālās politikas veidotāju līmenī partneri ir norādījuši šādas iesaistītās puses: Schleswig-Holstein Ministry for Social Affairs, Health, Science and Equality (PP1), Regional Council of Ostrobothnia (PP4), Labklājības ministrija (PP7), Ida-Viru County Government (PP10), Võru County Government (PP11), County Council of Norrbotten (PP13).

Resursi: iespēja noteikt un mainìt sociālo politiku, līdzekḷu pārdali un budžeta izmantošanu, līdzdalība Eiropas Savienības regulu un prasību, kā arī citu starptautisko normatīvu ieviešanā.

Iespējamā loma: savstarpējas konsultācijas, atbalsts procesu virzǐšanai birokrātiskajā aparātā, ietekme uz mediju ieinteresētību un aktivitātēm.

2. Sociālās politikas īstenotāju (valsts institūciju un pašvaldību) resursi un lomas.

Iesaistītās puses: Kreis Dithmarschen (PP1), Jobcenter Plön (PP2), Job Centers Nordfriesland in Sylt, Wyk of Fohr, Husum, Breklum, Tonning, Leck and Niebull (PP3), Finnish Unemployment Office (PP5), Priekules novada Sociālais dienests / Social Department of Priekule County Municipality (PP7), Social Insurance Agency (PP13).

Resursi: ietekme uz politikas veidotājiem, specifiska normatīvā ietvara pārzināšana, zināšanas par sociālo pakalpojumu galalietotājiem un iespējām viņus sasniegt, darba tirgus un regiionālā konteksta pārzināšana, statistiskas informācijas pārvaldība.

Iespējamā loma: konsultācijas, dalī̌anās pieredzē, ekspertu pakalpojumi, pieejamo komunikācijas kanālu izmantošana sociālo pakalpojumu galalietotāju sasniegšanai un iesaistišanai, mobilizēšanai, arī uzṇēmēju sasniegšana un mobilizēšana, ja tas ir nepieciešams.

3. Izglīīibas un pētniecības institūciju (skolu, universitāšu, akadēmiju, pètniecisko institūtu) resursi un lomas.

Iesaistītās puses: Latvijas Universitāte (PP08), Academy of Economics for Rural Areas (PP1), Harkujärve Elementary School 
(PP10), Estonian University of Life Sciences (PP11), University of Economics (PP12), Luleå University of Technology (PP13), Tornedalens Folk High School (PP14), University of South Denmark (PP15).

Resursi: zināšanas par sociālajām teorijām, pètījumu metodēm un datu analīzi, pieeja datubāzēm, akadēmisks skatījums, pedagoğiska pieredze, telpu pieejamība.

Iespējamā loma: konsultācijas, viedokḷa līderība, sadarbības tìklu veidošana, līdzdalība jaunrades procesos, datu apkopošana un analīze, iekšēju un ārēju ekspertu piesaiste, atbalsts komunikācijas kanālu nodrošināšanā.

\section{Darbnīcu, radošo centru, dienas centru resursi un lomas.}

Iesaistîtās puses: partneru iesūtītajos sarakstos šis iesaistīto/ieinteresēto pušu tips dažkārt minēts vispārīgi - kā "darbnīcas, radošie centri, mājražotāji (pārtikas ražošana, lauksaimniecības ekoloǵiskie, biolog̣iskie produkti, amatniecība)" un "dienas centri”.

Resursi: vieta aktivitātēm, aprīkojums un zināšanas par mācībām, mūžizglìtībai piemērotas telpas, tiešs kontakts ar sociālo pakalpojumu galalietotājiem, zināšanas un iemaņas darbā ar sociālo pakalpojumu galalietotājiem, izpratne un zināšanas par īpašām vajadzībām, praktiska pieredze.

Iespējamā loma: zināšanu apmaiņa, sociālo pakalpojumu galalietotāju iesaistǐšana, ekspertu zināšanu piedāvājums arodmācībās, dalīšanās ar labo prakšu piemēriem, līdzdalība jaunrades procesos.

\section{Nevalstisko organizāciju un to sadarbïbas tîklu resursi un lomas.}

Iesaistītās puses: LandfrauenVerband Schleswig-Holstein e.V. (PP1), Diakonie Plön-Segeberg (PP2), Paritatischer Wohlfahrtsverband Schleswig-Holstein e.V. (PP3), Finlands Svenska Socialförbund (PP4), Silta club (PP5), Apeirons (PP7), Pagegiai Anonymous Alcoholics Club Stiprybès šaltinis (PP9), Foundation for Social Action (PP10), Põlvamaa Association of Large Families (PP11).

Resursi: zināšanas par sociālo pakalpojumu galalietotājiem un vinu spēcināšanu, pieredze, sadarbỉbas tîkls, kontakti, telpas, aprīkojums, zināšanas un iemaṇas komandas darba veidošanā un sadarbības tīkla attīstǐšanā, organizatoriskas un komunikācijas prasmes, jomas autoritāte.

Iespējamā loma: viedokḷa līderi, konsultanti, sociālo pakalpojumu galalietotāju iesaistî̌ana, atbalsts mediju ieinteresēšanā, atbalsts 
sabiedriskajās attiecībās, pienesums diskusijās un spēcināšanas idejas iedzīvināšanā, darbs sadarbības tīklu veidošanā un vadīšanā, iespējama lìdzdalība pētijumu lauka darba stadijā.

\section{Uzņēmēju, tai skaitā sociālo uzñēmēju, resursi un lomas.}

Iesaistītās puses: Wirtschaftsförderungs-agentur Kreis Plön (PP2), Concordia (PP5), OÜ Garden (PP10), Samhall (PP13), Jokarjo (PP14).

Resursi: ekspertīze, zināšanas, pieredze, mentoru pakalpojumi, praktiska pieeja, potenciālas vai jau esošas darbavietas, potenciāli vai jau esoši pakalpojumi un produkti.

Iespējamā loma: konsultācijas, zināšanu aprite, pieredzes apmaiņa, sociālo pakalpojuma galalietotāju nodarbināšana, atbalsts uzñēmējdarbības pieejas izpratnei un uzsākšanai, komunikācijas prasmes un iemañas.

\section{Individuālo personu resursi un lomas.}

Iesaistītās puses: gimenes locekḷi, draugi, paziñas.

Resursi: zināšanas, pieredze, tuvums sociālo pakalpojuma galalietotājam.

Iespējamā loma: psiholog̣isks un informatīvs atbalsts un iedrošinājums, pieredzes un zināšanu apmaiṇa.

Apkopojot empīrisko materiālu par partneru iesaistìtām/ieinteresētām pusēm, jāsecina, ka zināšanu un pieredzes apmaiņa, kā arī konsultācijas ir to biežāk minētie resursu un funkciju piedāvājumi. Konsultācijas, zināšanu un pieredzes apmaiņa ir tas resurss, ar ko iesaistītās/ieinteresētās puses visbiežāk labprāt dalās. Tas nozīmē, ka veiksmīga komunikāciju platformas izveide ir būtisks priekšnosacījums, lai veidotos sadarbïbas tìkls, kurā informācijas, prasmju un ideju aprite varētu norisināties.

Katrai iesaistìto/ieinteresēto pušu grupai, pēc partneru sniegtajām ziņām, ir atšķirīgs resursu pienesums un atšķirīga funkcionālā loma. Kaut partneru sniegtajās ziņās tas nav minēts, tomēr noteikti jāñem vērā praktiskā iespēja, ka var nākties sastapties arī ar tādu iesaistīto/ieinteresēto pusi, kas var likt šķērš̌lus sekmīgai darbïbai, var būt nelabvēlīga, kavēt darbu. Iespējamo konfliktu paredzēšana, novēršana un risināšanas prasme ir būtiska iesaistīto/ieinteresēto pušu vadīšanas procesā. Konfliktu prevencijā un intervencijā ir noderīgas komandas darba organizēšanas un komunikācijas prasmes, kas ir svarīgas arī tîklošanās procesā.

Tīklošanās (networking) ir nozīmīgs atslēgvārds projekta partneru ziṇās par iesaistīto/ieinteresēto pušu funkcionālām lomām. Tiek 
izmantota jau esošo sadarbības tîklu pieredze un prasmes, kā arī veidoti jauni sociālie tīkli. Sadarbības tîkls ir nozīmīgs resurss, lai veidotu kopīgu projektu. Pašreizējo sadarbības tìklu pārstāvji var būt noderīgi konsultanti tieši komandas darba organizēšanā.

Analīze par iesaistìto/ieinteresēto pušu reālo veikumu lokālo spēcināšanas tìklu darbībā, to mijiedarbību un to savstarpējām attiecībām šajā pārskatā nav veikta, jo to kavē vairāku apstākḷu kopums. Pirmkārt, atšşirīgas ir partneru izvēètēs sociālo pakalpojumu galalietotāju grupas, otrkārt, astoṇās Eiropas Savienības Baltijas jūras regiiona valstīs ir atšķirīgs likumdošanas ietvars un sociālekonomiskais konteksts. Tik apjomīgu analīzi nepiel̦auj veikt šì projekta mērķi, uzdevumi un resursi. Taču vajadzības gadījumā to spēj izvērtēt katrs SEMPRE projekta partneris un lokālais spēcināšanas tīkls.

\section{Secinājumi}

Jēdziens “iesaistītās/ieinteresētās puses” ir izsenis lietots termins biznesa vadības vidē. Laika gaitā tā saturs ir paplašinājies un nozīme mainījusies. Mūsdienās šì plaši lietotā jēdziena galvenais saturs ir iesaistišanās, līdzdalība un griba ietekmēt notikumus un norises. Tā lietojums ir pārnests uz procesu vadīšanu visās darbības sfērās līdzịgi kā hrestomātiskā situācijas analīzes matrica.

Iesaistìto/ieinteresēto pušu analīze sastāv no trīs kanoniskām darbībām. Tās ir, pirmkārt, iesaistīto/ieinteresēto pušu identificēšana, otrkārt, iesaistīto/ieinteresēto pušu tipoloğijas izveide, treškārt, iesaistīto/ ieinteresēto pušu ietekmes spēka/pozīcijas noteikšana varas hierarhijā un savstarpējo attiecību diagnosticēšana.

Kopumā iesaistīto/ieinteresēto pušu apzināšana un iesaistī̌šna ir veiksmīgas darbỉbas un lietu gaitas svarīgs elements.

Sociālo pakalpojumu sniedzēju un galalietotāju sociāāa spēcināšanas efektivitāte ir atkarīga no harmonijas pakāpes iesaistīto/ieinteresēto pušu attiecībās un mijiedarbībā. Citādas pieejas, metodes, jaunas zināšanas, kritiska domāšana spēcina abus aktorus - sociālo pakalpojumu sniedzējus un galalietotājus. Sociālā spēcināšana vājo un viegli ievainojamo sociālo grupu kontekstā nozīmē šo grupu piekḷuvi dažāda veida resursiem, arī varai, un lēmumu pieņemšanas ietekmēšanu. 
SEMPRE projekta partneru iesaistīto/ieinteresēto pušu empīrisku datu analīze rāda, ka projekta īstenošanā piedalās visu līmeṇu iesaistìtās/ieinteresētās puses. Tās pārstāv nacionālās, reǵionālās un lokālās varas institūcijas un visi sabiedrības funkcionālie sektori - valsts vara, uzņēmējdarbība un pilsoniskā sabiedrība.

Identificētie iesaistīto/ieinteresēto pušu mērḳi ir diapazonā no sociālās politikas veidošanas un tās ietekmēšanas līdz filantropijai un empātijai sociālās labklājības jomā. Biežāk minētie mērḳi ir izglītošana, zināšanu pārnese, mūžizglītỉba, pētniecība, darbavietu radīšana.

Identificētie iesaistīto/ieinteresēto pušu resursi arī ir atkarīgi no to tipa un darbības līmeña. Vislielākie varas resursi sociālās politikas veidošanā un masu mediju ietekmēšanā ir pirmā līmeṇa iesaistītām/ ieinteresētām pusēm. Konsultācijas, dažādu zināšanu un pieredzes apmaiņa ir tas resurss, kas tiek minēts visbiežāk, un ar to iesaistīāa/ieinteresētās puses visbiežāk ir gatavas dalīties. Tīklošanās, telpu piedāvājums aktivitātēm, sociālās uzṇēmējdarbības iedibināšana un tuvība galalietotājiem ir citi izmantotie resursi.

Identificētās iesaistīto/ieinteresēto pušu lomas jeb funkcijas izriet no to tipa, darbỉbas līmeņa un resursiem. Biežāk SEMPRE projekta partneru minētās lomas ir lēmumu pieņēmēji, lobiji, vājo un viegli ievainojamo sociālo grupu advokāti, iesaistītāji daudzējādās aktivitātēs, viedokḷ līderi, izglītotāji, eksperti, konsultanti, padomdevēji, atbalstītāji, iedrošinātāji.

Tā kā SEMPRE projekta savdabīga iezīme ir gan projekta partnerības valstu sastāva, gan sociālo pakalpojumu galalietotāju struktūras dažādība, tad iesaistīto/ieinteresēto pušu savstarpējo attiecību un mijiedarbības kvalitātes analīze ir paveicama vien lokāliem iesaistīto/ ieinteresēto pušu pārzinātājiem.

\section{leteikums}

Iesaistīto/ieinteresēto pušu iniciatīvas un iesaistǐšanās sociālos procesos spēj mainìt un uzlabot gan sociālo pakalpojumu sniedzēju, gan sociālo pakalpojumu galalietotāju situāciju sociālās labklājības jomā. Tādēl sociālo pakalpojumu organizāciju/dienestu vadībai un personālam ir lietderīgi log̣iski izsvērt, kādas iesaistītās/ieinteresētās 
puses vēlams piesaistīt sadarbībai, lai veicinātu atsevišķas pozitīvas pārmaiṇas un pozitīvo pārmaiṇu procesu kopumā.

\section{Atsauces}

Calves, A. E. (2009) Empowerment: The History of a Key Concept in Contemporary Development Discourse. Doi: 10.3917/rtm.200.0735.

Clayton, M. (2014) The Origin of Stakeholders. In: The Influence Agenda. Palgrave Macmillan, London.

Davies, G. (1996) Tony Blair Puts the Meat on the Stakeholder Bones. Available: http://www.independent.co.uk/news/business/tony-blair-puts-meat-on-thestakeholder-bones-1324167.html [accessed: October 27, 2017].

Freeman, R. E. (1984; 2010) Strategic Management: A Stakeholder Approach. Cambridge University Press.

Friedman, A. L., Miles, S. (2006) Stakeholders. Theory and Practice. Oxford: Oxford University Press.

Gijselinckx, C. (2009) Co-operative Stakeholders. Who Counts in Co-operatives, and How? Working Papers on Social and Co-operative Entrepeneurship. Catholic University of Leuven.

Korpa, V. (2012) Darba un ġimenes dzīves saskaṇošana privātā sektora organizācijās. Promocijas darbs. Rīga: LU.

Ramirez, R. (1999) Stakeholder Analysis and Conflict Management. In: Buckles, D. (ed.) Cultivating Peace: Conflict and Collaboration in Natural Resource Management. Canada, Ottawa.

Reed, M. S. et al. (2009) Who's in and why? A typology of stakeholder analysis methods for natural resource management. Available: https://doi.org/10.1016/j. jenvman [accessed: October 27, 2017].

Schmeer, K. (n. d.) Stakeholder Analyze Guidelines. Available: http://www.who. int/workforcealliance/knowledge/toolkit/33.pdf [accessed: October 27, 2017].

SEMPRE project. Available: http://sempre-project.eu/about-the-project [accessed: October 27, 2017].

United Kingdom Government, Department for International Development. Guidance Note on How to do Stakeholder Analysis of Aid Projects and Programmes (1995). London. Available: https://beamexchange.org/uploads/filer_public/5d/4c/5d4c7b02-a25d-43ab-ae33-0e4811b7c5fb/guidance_stakeholderanalysis.pdf [accessed: October 27, 2017].

World Bank. Stakeholder Analysis (2001) Available: http://www1.worldbank. org/publicsector/anticorrupt/PoliticalEconomy/stakeholderanalysis.htm [accessed: October 27, 2017].

World Wildlife Fund. Cross Cutting Tool: Stakeholder Analysis (2005). Available: www.panda.org/standards/1_1_stakeholder_analysis/ [accessed: October 27, 2017]. 


\title{
Laura Jaunromāne
}

\section{Personu ar invaliditāti vajadzības Grobinas, Priekules, Rucavas novadā un Liepājā̄ ${ }^{1}$}

\author{
Needs Assessment of Persons with Disabilities \\ in Grobina, Priekule, Rucava Counties and \\ Liepāja Town in Kurzeme Region of Latvia
}

\begin{abstract}
Summary
Publication yields an insight into the situation of adults with disability. Although empirical research covers three counties and Liepāja town in Kurzeme region, it is reasonable to assume that results would be similar in other counties and regions of Latvia.

Firstly, the article reflects a discussion dedicated to the use of concepts regarding the disability and persons with disability. In Latvia, the transition from medical to social or human rights approach regarding the persons with disability has started, yet still is not implemented, as the political discourse mainly focuses on abilities instead of barriers and obstacles.

Secondly, the article includes an overview of important social policy making documents relevant to persons with disabilities. It considers the international agreement "United Nations Convention on the Rights of Persons with Disabilities" and related national level guidelines of implementation and monitoring, the European Commission's Strategy "Europe 2020", the main strategic documents of the Republic of Latvia - "Latvia 2030" and "National Development Plan 2020", as well as a list of national level social policy guidelines by state ministries. Policy documents of this level do apprize the necessity for supportive actions and social service offer to persons with disability.
\end{abstract}

1 Raksta zinātnisko struktūru veidojusi Anna Stepčenko. 
Thirdly, the article includes an analysis of empirical needs' assessment. Empirical research includes eleven individual and group interviews, whereby 49 contact persons were reached - 34 persons with disability, nine municipal social service providers and six representatives from institutions for people with disabilities. Additionally, the relevant normative documents are linked with the revealed needs to provide a more extensive insight into the problem situation. The assessment shows a range of needs, notably, not all the persons experience all the listed problem situations and needs. Nevertheless, the empirically revealed material, emotional and social needs are interconnected and overlap in many aspects. The following areas of needs or problem situation were disclosed: 1 . health and health care, 2. finances, 3 . housing quality, 4. everyday life duties, 5. transport, 6. employment, 7. workshops, 8. leisure time and day centers, 9. interaction in society, 10. childcare, 11. social contacts, family, 12. ability to act, 13 . overcoming addictions. The listed areas are not arranged hierarchically. However, a short overview of the assessed needs in context of Maslow's motivation theory is offered to yield an insight into the range of needs. Additionally, an insight into cases of involvement of persons with disabilities in social service provision is given.

Policy recommendations include, not only but also the following: 1. to continue to move towards discourse of human rights approach regarding the persons with disability, 2. to aim for more relevant resultative indicators regarding the persons with disabilities in the policy strategies, especially implementation of UN Convention, 3. in context of DI plan $^{2}$, an active monitoring of the changes in the attitude of society and a possibility to separate data regarding persons with disabilities in the statistical data of criminal offence register is strictly recommended, 4 . to find possibility to offer more than two hours a week of assistant work for free or leisure time for people with disabilities who need the assistance to assure the possibility to exit the house at least few times a week, 5. to avoid any delay of implementation or derogation in terms of transport availability, especially in rural areas.

Key words: persons with disability, needs assessment, involvement.

2 DI - deinstitutionalization

Deinstitutionalisation is establishment of a system of services providing the necessary support to a person who has limited ability of taking care of himself or herself so that he or she could live at home or in a family environment. The implementation of the DI plan in Latvia is led by the Ministry of Welfare. The DI Target Groups in the Planning period 2015-2020 are (1) children in out-offamily care; (2) children with functional disorders; (3) adult persons with mental disorders (Ministry of Welfare, 2016, pp. 3-4). 


\section{Kopsavilkums}

Publikācija sniedz ieskatu pilngadīgu personu ar invaliditāti situācijā. Kaut arī empīriskā izpēte veikta tikai trijos Kurzemes reǵiona novados un Liepājā, tomēr ir pamats uzskatīt, ka līdzīgi rezultāti būtu arī citos Latvijas reǵionos un novados. Publikācija ietver diskusiju par jēdzienu lietojumu, runājot par invaliditāti un personām ar invaliditāti, piedāvā pārskatu par nozīmīgiem politikas veidošanas dokumentiem attiecībā uz personām ar invaliditāti, kā arī sasaista šos un citus normatīvos dokumentus ar empīiskajā pētijumā atklātajām vajadzībām. Apzinātajām vajadzībām sniegts ìss pārskats Maslova motivācijas teorijas kontekstā. Intervijās, kas veiktas 2016. gada vasarā, sasniegtas 49 kontaktpersonas - personas ar invaliditāti, sociālo dienestu pārstāvji, institūciju pārstāvji. Papildus sniegts ieskats intervijās minētajos gadījumos, ko var identificēt kā personu ar invaliditāti iesaistî̌anu un iesaistī̌sanos sociālo pakalpojumu sniegšanā un problēmsituāciju risināšanā. Raksta noslēgumā ir secinājumi un ieteikumi.

Atslēgvārdi: personas ar invaliditāti, sociālās politikas veidošanas dokumenti, vajadzību apzināšana, iesaistīšana un iesaistī̌šanās.

Tematika. Invaliditāte un personas ar invaliditāti. Politikas veidošanas dokumenti attiecībā uz personām ar invaliditāti. Personu ar invaliditāti vajadzības. Vajadzības Maslova motivācijas teorijā. Vajadzību apzināšanas metodoloǵija. Vajadzības (veselība un veselības aprūpe; finanses; dzīvesvietas kvalitāte; ikdienas darbu veikšana; transports; nodarbinātība; darbnīcas; brīvais laiks un dienas centri; sabiedrības attieksme; bērnu aprūpe; sociālie kontakti, ǵimene; spēja darboties; atkarību pārvarēšana). Personu ar invaliditāti iesaistǐšana un iesaistī̌̌anās sociālo pakalpojumu sniegšanā.

\section{levads}

Saskaņā ar oficiālo statistiku (VDEĀVK, 2017) par 2016. gadu Latvijā ir 182048 cilvēki ar invaliditāti, kas ir 9,3\% no visiem valsts iedzīvotājiem. 2015. gadā tie bija 8,1\%. No 2009. līdz 2016. gadam registrēto personu ar invaliditāti skaits pieaudzis par vairāk nekā 40 tūkstošiem, kamēr iedzīvotāju skaits valstī turpina sarukt.

Invaliditātes pirmreizējā reǵistrēšana saistìta gan ar attiecīgā statusa pieņemšanu, gan iespēju izmantot pienākošos atvieglojumus, saņemt invaliditātes pensiju. Centrālās statistikas pārvalde (2017a) ziṇo, ka 2015. gadā vairāk nekā $20 \%$ valsts iedzīvotāju ir pakḷauti nabadzības riskam; tajā skaitā 55\% bezdarbnieku. Tajā pašā laikā Nodarbinātības valsts agentūras 2017. gadā sniegtā informācija (Paparde, 2017) 
liecina, ka mazāk nekā ceturtā daļa personu ar (visu grupu) invaliditāti ir nodarbinātas. Ekonomiskā situācija ir viens no faktoriem, kas nosaka reǵistrēto personu ar invaliditāti skaita pieaugumu.

Dati par personu ar invaliditāti skaita nemitīgo pieaugumu faktiski liecina, ka ir virkne iedzīvotāju, kas ilglaicīgi valsts un pašvaldỉbu iespējamo atbalstu nav saṇēmuši, un ticams, ka ir tādi, kas joprojām nesañem, jo invaliditāte nav tikusi reg̣istrēta. Invaliditātes reǵistrēšanas procesā nozīme ir ne tikai statusa maiņas sociālajiem un psihologiskajiem aspektiem, bet arī sociāli domājošu gimenes ārstu un sociālo dienestu darbinieku atbalstam, lai šo procesu varētu paveikt.

Savlaicīgas kvalitatīvas veselības aprūpes trūkums var būt gan vēl viens faktors, kas liecina par to, ka pieaug to personu skaits, kam invaliditāte reǵistrēta pirmo reizi, gan arī iemesls invaliditātes attīstībai smagākā formā.

Nepieciešamību pēc papildu atbalsta - pēc sociālajiem pakalpojumiem un citiem atbalsta instrumentiem - personām ar invaliditāti apstiprina 2014. gadā Sabiedrības integrācijas fonda publicētais "Pētijums par pretdiskriminācijas politikas uzraudzības sistēmas izstrādi” (Hazans, Kḷave, Zepa, 2014) - analizējot faktisko nevienlīdzību starp personām ar invaliditāti un personām bez tās, secināts, ka problēmsituācijas ir gan nodarbinātības, gan labklājības, gan veselības un izglitîbas jomā.

Tiesībsarga publicētajos Latvijas iedzivotāju aptaujas rezultātos (Latvijas Republikas tiesībsargs, 2014) par personu ar invaliditāti tiesībām uzsvērta neviennozīmīgā sabiedrības attieksme, tomēr interesanti arī tas, ka no reprezentatīvi atlasītajiem respondentiem trešajai daļai paziṇu lokā nav pazīstama neviena persona ar invaliditāti. Jāṇem gan vērā, ka invaliditāte ne vienmēr ir redzama, tāpēc iespējams, ka respondenti ne vienmēr var zināt, vai paziņu lokā ir vai nav kāda persona ar invaliditāti. Te vēlos minēt kādu notikumu publiskajā telpā 2017. gadā. Veselības ministrija bija cenzējusi izstādes "Neredzamās zonas" (Paula Stradiṇa Medicinas vēstures muzejs, 2017) plakātu (Delfi, 2017). Šajā izstādē varēja iepazīties ar poḷu fotogrāfa A. Žmijevska fotogrāfijām, kurās bija redzami cilvēki ar invaliditāti. Cenzēšana sabiedrības diskusiju ne tikai veicināja (Vīnbergs, 2017), bet arī tomēr ierobežoja. Iespējams, viens no kritiskajiem faktoriem ir mūsu neprasme domāt par cilvēkiem ar invaliditāti un runāt par to.

Šìs publikācijas mērḳis ir sniegt ieskatu pilngadīgu personu ar invaliditāti situācijā. Sākotnēji tā bija iecerēta kā cilvēku ar invaliditāti 
vajadzību izpēte, kā atbalsts mikroprojekta realizācijai projekta SEMPRE ietvaros, tomēr publikācija izvērtās plašāka, skatot gan terminu lietojumu politikas dokumentos un normatīvajos aktos, gan politikas pamatnostādṇu sasaisti ar empīriskās izpētes rezultātiem (personu ar invaliditāti vajadzības tika pētītas Grobiņas, Priekules un Rucavas novadā, kā arī Liepājā). Analizējot intervijas, papildu uzmanība veltīta arī personu ar invaliditāti iesaistīšanai sociālo pakalpojumu sniegšanā. Uzmanība pievērsta arī tam, kā viṇi paši iesaistās problēmsituāciju risināšanā. Intervijās, kas veiktas 2016. gada vasarā, sasniegtas 49 kontaktpersonas - personas ar invaliditāti, sociālo dienestu un citu institūciju pārstāvji.

Paradigmas maiņai no medicīniskā modeḷa uz sociālo modeli attiecībā uz personām ar invaliditāti būtisks ir vajadzību izpētes galvenais secinājums - personām ar invaliditāti ir tādas pašas vajadzības kā visiem cilvēkiem. Lai cik banāls šis secinājums neliktos, tomēr pārliecību, ka šì ir internalizēta norma, neapstiprina, piemēram, fakts, ka augstākās valsts pārvaldes līmeņa diskursā joprojām parādās termins "invalīds" un ka asistenta pakalpojuma pieejamībai brīvā laika pavadīšanai personām ar invaliditāti atvēlētas ne vairāk kā divas stundas nedēḷā. Spēja domāt un runāt par invaliditāti ar cilvēkiem ar invaliditāti kā līdzvērtīgiem ir nozīmīgs priekšnoteikums, lai notiktu diskusija, kas vērsta uz paradigmas maiņu, kura šobrīd vēl nav notikusi. Lai spētu saskatīt tiesību vienlīdzību, ir jāatzīst arī līdztiesīgas vajadzības.

\section{Invaliditāte un personas ar invaliditāti}

Apvienoto Nāciju Organizācijas Konvencijā par personu ar invaliditāti tiesībām (turpmāk - Konvencija) (ANO, 2006) par invaliditātes jēdzienu teikts, "ka invaliditātes jēdziens pastāvīgi attīstās un ka invaliditāte rodas, cilvēkiem ar funkcionāliem traucējumiem, saskaroties ar attieksmes un apkārtējās vides šķēršliem, kas ierobežo vienlīdzīgas iespējas pilnvērtīgi un efektīvi līdzdarboties sabiedrïbas dzīvē" (ANO, 2006, preambula).

ANO Konvencijas preambulā uzsvērta invaliditātes jēdziena atrašanās pārmaiṇu procesā, izpratnes maiņa un attīstība. Te būtisks nevis pats jēdziena "invaliditāte" lietojums, bet gan kontekstuālais ietvars. 
Attieksmes un apkārtējās vides šḳēršḷi kā vienlīdzīgu iespēju ierobežojums ir tas, kas nosaka ši jēdziena nepieciešamību, un nevis cilvēka funkcionālie traucējumi. ANO Konvencija personu ar invaliditāti definē šādi: "Pie personām ar invaliditāti pieder personas, kurām ir ilgstoši fiziski, garīgi, intelektuāli vai maṇu traucējumi, kas mijiedarbībā ar dažādiem šķērš̌liem var apgrūtināt to pilnvērtīgu un efektīvu līdzdalību sabiedrības dzìvē vienlīdzīgi ar citiem.” (ANO, 2006)

Arī šajā definīcijā šķēeššli parādās kā nozīmīgais aǵents, un tie personai ar funkcionāliem traucējumiem ir apgrūtinoši. Tāpat arī vēršu uzmanību, ka Konvencijā nosaukti četri traucējumu veidi - fiziski, garīgi, intelektuāli un maņu; tie Latvijas Invaliditātes likumā neparādās.

Invaliditātes likums (Saeima, 2010a ${ }^{3}$ ) invaliditāti un personas ar invaliditāti definē šādi: "Invaliditāte ir ilgstošs vai nepārejošs ḷoti smagas, smagas vai mērenas pakāpes funkcionēšanas ierobežojums, kas ietekmē personas garīgās vai fiziskās spējas, darbspējas, pašaprūpi un iekḷaušanos sabiedrībā. [..] Persona ar invaliditāti - persona, kurai šajā likumā paredzētajā kārtībā ir noteikta invaliditāte." (Saeima, 2010a)

Šì definīcija vērsta uz personas spējām, nevis šķērṣ̌liem, ar ko šī persona saskaras. Jāṇem gan vērā, ka Invaliditātes likuma mērḳis ir "novērst vai mazināt invaliditātes risku personām ar prognozējamu invaliditāti un mazināt invaliditātes sekas personām ar invaliditāti”, likuma uzdevums ir noteiktas sabiedrības grupas tiesību stiprināšana, tādējādi šāda pieeja, definējot pašu grupu (spēju ierobežojumu, kas raksturo konkrētu indivīdu), nevis ārējos šḳēršșus, sniedz lielāku konkrētību un juridisku funkcionētspēju.

Invaliditātes likums (Saeima, 2010a) nosaka personu ar invaliditāti loku un paredz invaliditātes iedalījumu grupās (personām, kas vecākas par 18 gadiem), izvērtējot funkcionēšanas ierobežojumu un tā pakāpi, kā arī nosakot darbspēju zaudējumu procentos un invaliditātes grupas. Ir šāds iedalijums:

a) I invaliditātes grupa, ja darbspēju zaudējums ir $80-100 \%$ apmērā, - ḷoti smaga invaliditāte;

\footnotetext{
Izmantoto avotu un literatūras atsaucēs aiz gadskaiț̣a vai norādes "b.g." (bez gada) vai "n.d." (no date - angḷu valodā) burts (a, b, c, d, e utt.) lietots, lai atšḳirtu atsauces uz viena avota vairākām publikācijām viena gada ietvaros.
} 
b) II invaliditātes grupa, ja darbspēju zaudējums ir $60-79 \%$ apmērā, - smaga invaliditāte;

c) III invaliditātes grupa, ja darbspēju zaudējums ir 25-59\% apmērā, - mēreni izteikta invaliditāte (Saeima, 2010a).

Invaliditātes noteikšanas procesu uzrauga Labklājības ministrijas (turpmāk - LM) pārziņā esošā Veselības un darbspēju ekspertīzes ārstu valsts komisija (VDEĀVK, b.g.).

Kopš 2015. gada Invaliditātes likumā, definējot invaliditātes grupu, tiek skatìts darbspēju zudums, nevis veselības traucējumi. Tas iezīmē pāreju uz aktivitāšu un funkcionēšanas ierobežojumu, nevis piemītoša veselïbas trūkuma skatīšanu. Lìdz 2015. gadam darbspēju zaudējums invaliditātes grupas definīcijā nebija noteikts. Izmaiṇas saistāmas ar paradigmas maiņu izpratnē par invaliditāti, ko starptautiska līguma līmenī 2006. gadā definējusi ANO Konvencija par personu ar invaliditāti tiesībām (ANO, 2006). Latvija to ratificējusi 2010. gadā, kad pieṇemts arī no 2011. gada spēkā esošais Invaliditātes likums. Latvijas ANO Konvencijas par personu ar invaliditāti tiesībām īstenošanas pamatnostādnēs 2014.-2020. gadam (turpmāk - Pamatnostādnes) uzsvērts: "Konvencija nosaka pāreju no medicīniskā modeḷa, kas uzsver cilvēka nespēju un atkarību no citiem cilvēkiem, uz cilvēktiesību modeli, kur uzsvars tiek likts uz personas ar invaliditāti tiesībām un patstāvīgu dzīvi un aktīvu lïdzdalību sabiedriskajos procesos." (Saeima, 2013a)

Šis izcēlums Pamatnostādṇu ievadā var radīt maldīgu priekšstatu par veselības aprūpes nozīmes mazināšanos. Konvencija neatceḷ veselības aprūpes nodrošināšanas nepieciešamību, tā izceḷ invaliditātes sociālā modeḷa nozīmi. Konvencijas principi sasaucas arī ar kopējo paradigmas maiṇu (medicīnā) no biomedicinas uz biopsihosociālu pieeju, holistiska principa ievērošanu.

Latvijas Invaliditātes likuma izmaiṇās vērojamā diskursa maiṇa no veselības traucējumu izcēluma uz funkcionēšanas ierobežojumu izcēlumu ir solis tuvāk invaliditātes sociālā modeļa realizēšanai, tomēr uzsvars uz personas spējām, nevis ārējiem ierobežojumiem, ar ko šì persona saskaras, norāda, ka pāreja uz sociālo modeli likumdošanas diskursā nav realizēta.

Lìdz 2010. gadam, kad tika pieņemts Invaliditātes likums (Saeima, 2010a), plaši tika lietots termins "invalīds", piemēram, VDEĀVK izsniedza "Invalīda apliecību" (Apeirons, 2011). Pēc Invaliditātes likuma pieṇemšanas termins "invalīds" tika aizstāts ar terminu "persona ar 
invaliditāti", attiecīgi šobrīd Latvijā tiek izsniegta "Invaliditātes apliecība”. Centrālā statistikas pārvalde (turpmāk - CSP) 2017. gada beigās joprojām izmanto rādītājus, kur lietots termins "invalīds", piemēram, "Pirmoreiz par invalīdiem atzìto iedzivotāju skaits" un "Pirmoreiz par invalīdiem atzīto iedzīvotāju skaits pēc invaliditātes cēloṇiem” (Centrāāā statistikas pārvalde, b.g.). Arī VDEĀVK 2017. gadā publicētajā publiskajā pārskatā par 2016. gadu (VDEĀVK, 2017) parādās termins "invalīds". Arī Satiksmes ministrija (b.g.) 2017. gada beigās braukšanas maksas atvieglojumu kontekstā joprojām lieto terminu "invalīds".

Galvenajā valsts plānošanas dokumentā "Latvijas ilgtspējīgas attīstības stratēgija lìdz 2030. gadam" lietots termins "persona ar funkcionāliem traucējumiem". Sociālo pakalpojumu un sociālās palīdzības likumā (Saeima, 2002a) lietots šis termins, kam sniegts skaidrojums: "funkcionālais traucējums - slimības, traumas vai iedzimta defekta izraisīts fiziska vai garīga rakstura traucējums, kas ierobežo personas spējas strādāt, aprūpēt sevi un apgrūtina personas iekḷaušanos sabiedrībā" (Saeima, 2002a).

Sabiedrības integrācijas fonda lapā publicētajā biedrības "Latvijas kustība par neatkarīgu dzīvi” 2010. gada pētījumā "Ziṇojums par cilvēku ar funkcionāliem traucējumiem vajadzību iekḷāvumu nacionālos un reǵionālos plānošanas dokumentos" (Latvijas Kustỉba par neatkarību dzivi, 2010) izmantots šis termins. Biežāk termins "persona ar funkcionāliem traucējumiem" lietots paralēli terminam "persona ar invaliditāti” sociālās rehabilitācijas kontekstā (MK, 2009a; Labklājības ministrija, b.g.e.), kur nepieciešams definēt funkcionālo traucējumu veidu un smagumu atbilstošas rehabilitācijas pasākumu noteikšanai.

Saskaņā ar Civilprocesa likuma 72. panta pirmo dalı (Saeima, 1998) termins "persona ar ierobežotu rīcībspēju" var tikt attiecināts uz personu ar invaliditāti tikai tad, ja rīcībspējas ierobežošanu ir noteikusi tiesa. Šo terminu būtiski nošķirt no termina "persona ar funkcionēšanas (vai funkcionāliem) ierobežojumiem”, kur funkcionālie ierobežojumi ir sinonīms funkcionāliem traucējumiem.

Vēl viens sabiedrībā lietots formulējums ir "cilvēki arī ìpašām vajadzībām”. Minētais formulējums lietots, piemēram, Latvijas lielākās organizācijas, kas apvieno šo cilvēku grupu, nosaukumā "Latvijas Cilvēku ar ìpašām vajadzībām sadarbības organizācija "Sustento"” (Sustento, b.g.). Tomēr šis termins (angḷu val. special needs) ir saṇēmis kritiku, jo normālas vajadzības tiek padarītas par īpašām, tādējādi 
stigmatizējot noteiktu grupu (Finklestein, Stuart, 1996); arī Rīgas Stradiña universitātes doktorante Baiba Baikovska uzsver, ka tas nav atbilstošs mūsdienu izpratnei par iekḷaujošu un līdztiesīgu sabiedrību (Baikovska, 2017). Tāpat arī šajā publikācijā aprakstītā empīriskā izpēte apliecina, ka personu ar invaliditāti vajadzības ir tādas pašas kā visiem cilvēkiem; ierobežojums ir iespējās tās realizēt.

Viens no argumentiem pret termina "persona ar invaliditāti" lietošanu ir tā etimologiskās izcelsmes nozīme - nespēcīgs (latīṇu val. in - ne; validus - spēcīgs), ko vēl vairāk pastiprina daudz plašāk zināmās angḷu valodas konotācija - nederīgs (angḷu val. in - ne; valid derīgs). Tomēr, tā kā šobrīd nav līdzvērtīga termina, kas ietvertu ārējo apstākḷu šķēršlu radīto apgrūtinājumu, nevēršot uzmanību uz personas spējām vai varēšanu, tad publikācijā saglabāts juridiski korektais termins "persona ar invaliditāti".

Terminu izvēlei ir būtiska nozīme publiskā diskursa veidošanā. Ir nepieciešama tālāka diskusija par terminu izvēli un lietojumu politikas dokumentos un publiskajā telpā saistỉbā ar cilvēkiem ar invaliditāti. Te vietā atzīmēt, ka viens no četriem prioritāri izvirzītajiem rīcības virzieniem ANO Konvencijas ìstenošanai Latvijā laika posmā no 2014. līdz 2020. gadam (Saeima 2013a) ir sabiedrïbas izpratne.

Termini "persona ar invaliditāti" un "cilvēks ar invaliditāti”, kas izmantoti šajā publikācijā, nav ideāli. Līdzšinējā diskusija parāda to, ka pāreja uz invaliditātes sociālo vai cilvēktiesību modeli ietver arī lietotās valodas izvērtēšanu, nepieciešamību pēc jaunām, atbilstošākām praksēm valodā.

\section{Politikas veidošanas dokumenti personām ar invaliditāti}

Personu ar invaliditāti situāciju katras valsts kontekstā ietekmē likumi, starptautiskie līgumi, apņemšanās un nodomi, kas ietverti politikas veidošanas dokumentos. Valsts pamatlikums ar augstāko juridisko spēku - Latvijas Republikas Satversme - nosaka: "Visi cilvēki Latvijā ir vienlīdzīgi likuma un tiesas priekšā. Cilvēka tiesības tiek istenotas bez jebkādas diskriminācijas.” (Latvijas Republikas Satversme, 1918) Tas nozìmē, ka valsts likumos noteiktais un ministriju pamatnostādṇu 
dokumentos aprakstītais attiecināms uz personām ar invaliditāti pat tad, ja šī iedzīvotāju grupa netiek īpaši izcelta. Lỉdztekus dokumentos ir virkne aspektu, kur īpaši uzsvērta nepieciešamība vērst papildu uzmanību un veidot atbalsta pasākumus, lai realizētu personu ar invaliditāti tiesības. Šajā nodạ̄ā sniegts îss ieskats nozīmīgākajos politikas veidošanas dokumentos personām ar invaliditāti. Plašāks ieskats 1. pielikumā.

ANO Konvencija par personu ar invaliditāti tiesībām (ANO, 2006) ir starptautisks līgums, ko Latvija ir pieṇēmusi 2006. gadā un ratificējusi 2010. gadā; 2013. gadā izstrādātas ANO Konvencijas īstenošanas pamatnostādnes. Šis ir apjomīgākais politikas dokuments, kura mērḳis ir veicināt personu ar invaliditāti cilvēktiesību un pamatbrīvību ievērošanu. ANO Konvencija skaidri iezīmē pāreju no medicīniskā modeḷa uz sociālo jeb cilvēktiesību modeli attiecībā uz personām ar invaliditāti. Tas nozīmē vērst uzmanību ārējo šḳēešşu ietekmes mazināšanai, veidojot vidi, kurā personas ar invaliditāti var realizēt savas tiesības tāpat kā personas bez invaliditātes.

Apvienoto Nāciju Organizācijas Konvencijas par personu ar invaliditāti tiesībām īstenošanas pamatnostādnes 2014.-2020. gadam (Saeima, 2013a) ir vidēja līmeņa politikas plānošanas dokuments, kas izstrādāts, lai īstenotu ANO Konvencijā izvirzītos mērķus un veicamos uzdevumus. Latvijā par prioritārajiem rīcības virzieniem un mērķiem noteikti: (1) izglìtība, (2) darbs un nodarbinātîba, (3) sociālā aizsardzība, (4) sabiedribas izpratne.

2017. gada augustā Labklājības ministrija publicējusi "Indikatoru sarakstu ANO Konvencijas par personu ar invaliditāti tiesībām monitoringam" (Labklājības ministrija, 2017a). Dokuments nozīmīgs, jo nosauc konkrētus indikatorus monitoringam. Piedāvāto indikatoru izvēle ne vienmēr ir saprotama un log̣iski sasaistīta ar problēmjautājumu, tāpat arī līdzšinējo pētỉjumu datu interpretācija (Latvijas Republikas tiesībsargs, 2014) ne vienmēr ir korekta (skat. 1. pielikumu). Indikatoru saraksts ir noderīgs rīks, lai monitorētu personu ar invaliditāti tiesību īstenošanas virzību. Tomēr, lai tas darbotos, tam būtu jābūt izstrādātam kvalitatīvi.

Latvijas ilgtspējīgas attīstības stratēgija līdz 2030. gadam ("Latvija 2030”) (Saeima, 2010b) ir galvenais valsts plānošanas dokuments. Personu ar invaliditāti situācija īpaši skatīta deviṇos dokumenta paragrāfos, kas ietver tādas jomas kā darba tirgus, sabiedrības informēšana, 
sociālās programmas, vides un informācijas pieejamība, izglìtība. Galvenais valsts plānošanas dokuments vērš uzmanību no tādu šḳēešlı mazināšanu, kas ierobežo personu ar invaliditāti tiesības un iespējas.

"Eiropa 2020" (European Commission, n.d.) ir ES darbavietu radī̌anas un izaugsmes desmit gadu stratēégija. To sāka îstenot 2010. gadā, lai radītu apstākḷus gudrai, ilgtspējīgai un iekḷaujošai izaugsmei. Viens no stratēgijas "Eiropa 2020" pamatmērḳiem ir sociālā iekḷautība un nabadzības mazināšana. Saskaņā ar šo Latvijai saistošo stratēgiju sociālā iekḷautība attiecināma uz darbu un izglìtību un spēcina cilvēku ar invaliditāti tiesības. ES dalībvalstu ekonomiskajām un sociālajām reformām jābūt saskaņotām ar stratēgijas "Eiropa 2020" mērḳiem.

Latvijas Nacionālais attīstības plāns 2014.-2020. gadam ("NAP 2020") (Saeima, 2013b) ir galvenais vidēja termiņa valsts attīstības plānošanas dokuments. Tajā ir izvirzìtas trīs prioritātes: (1) tautas saimniecības izaugsme, (2) cilvēka drošumspēja, (3) izaugsmi atbalstošas teritorijas. Katrai prioritātei seko trīs līdz pieci rīcības virzieni: personu ar invaliditāti ciešākas integrācijas nepieciešamība uzsvērta prioritātes "Cilvēka drošumspēja" rīcības virzienā "Cienīgs darbs".

Sabiedrības veselības pamatnostādnes 2014.-2020. gadam (turpmāk - SV pamatnostādnes) (Saeima, 2013c) ir nozīmīgs dokuments personām ar invaliditāti, jo, kaut arī ne vienmēr, tomēr invaliditāte nereti cieši saistìta ar papildu veselības aprūpes nepieciešamību, būtiska ir tās pieejamība. Veselības aprūpe ir viens no SV pamatnostādṇu jautājumiem. SV pamatnostādṇu ievadā īpaši uzsvērtas sociālās atstumtības un nabadzības riskam pakḷauto iedzīvotāju grupu, tātad arī personu ar invaliditāti, vajadzības.

Pamatnostādnes sociālo pakalpojumu attīstībai 2014.-2020. gadam (turpmāk - SP pamatnostādnes) (Saeima, 2013d) ir nozīmīgas personām ar invaliditāti, jo no sociālo pakalpojumu pieejamības un kvalitātes lielā mērā ir atkarīgas iespējas realizēt pienākošās cilvēktiesỉbas un pamatbrīvības, kā to paredz ANO Konvencija. Viens no šajā dokumentā minētajiem uzdevumiem ir Deinstitucionalizācijas plāna (turpmāk - DI plāns) izstrāde, kas 2015. gadā ir paveikta; 2017. gadā aktīvi norit rīcības plāna realizēšana, sadarbojoties ar pašvaldībām. Viena no nozīmīgākajām iesaistītajām valsts institūcijām SP pamatnostādṇu realizācijā ir Sociālās integrācijas valsts aǵentūra.

Rīcības plāns deinstitucionalizācijas ìstenošanai 2015.2020. gadam (Labklājības ministrija, 2015b). "Deinstitucionalizācija 
(turpmāk - DI) ir pakalpojumu sistēmas izveide, kas sniedz personai, kurai ir ierobežotas spējas sevi aprūpēt, nepieciešamo atbalstu, lai tā spētu dzìvot mājās vai ğimeniskā vidē.” (Labklājības ministrija, 2015b, 3) Periodā līdz 2020. gadam Latvijā DI prioritārās mērkgrupas ir ārpusǵimenes aprūpē esošie bērni, bērni ar funkcionāliem traucējumiem un pilngadīgas personas ar garīga rakstura traucējumiem.

DI process nav jauns virziens pasaulē. Piemēram, ASV šis process norisinājās 20. gs. 50. un 60. gados. Viens no mērķiem toreiz bija pēc DI realizēšanas panākt izmaksu samazināšanu un meklēt lētāku alternatīvu institūcijām. DI ir saņēmusi arī vērā ņemamu kritiku, diskusija par šì procesa rezultātā radītājiem ieguvumiem un zaudējumiem joprojām ir aktuāla (Bagenstos, 2012; Perry, 2016; Lamb, Bachrach, 2001). Pētijumos uzsvērts, ka DI plāna realizācijā būtiski nodrošināt sabiedrībā balstītu pakalpojumu pieejamību un sabiedrības izpratni un atbalstu.

Profesionālā sociālā darba attīstības pamatnostādnes 2014.2020. gadam (turpmāk - SD pamatnostādnes) (Saeima, 2013e) personām ar invaliditāti ir nozīmīgas, jo sociālā darba attīstîba ir būtiska komponente sociālo pakalpojumu saṇemšanā. SD pamatnostādnēs kā svarīgākais saistītais starptautiskais dokuments minēta Eiropas Sociālā harta (turpmāk - ESH) (Eiropas Padome, 1961). Lai arī Saeima ir pieṇēmusi un Valsts prezidents 2001. gadā izsludinājis deklarāciju par ESH, tomēr Latvijai ESH 15. pants "Invalīdu un garīgi atpalikušu personu tiesības uz arodapmācību, rehabilitāciju un sociālo iekārtošanu” nav viens no šìs deklarācijas saistošajiem pantiem (Saeima, 2001b), tādēḷ ESH šajā publikācijā netiek skatīta plašāk.

Izglìīibas attīstỉbas pamatnostādnes 2014.-2020. gadam (turpmāk - IA pamatnostādnes) (Izglītības un zinātnes ministrija, 2013) kā vienu no rīcības virzieniem min iekl̦aujošās izglìtỉbas principa īstenošanu un sociālās atstumtības riska mazināšanu. Tāpat arī šis dokuments paredz atbalstu būvdarbiem, iekārtu, aprīkojuma un tehnolog̣iju iegādei un izglìtības iestāžu pielāgošanai personām ar funkcionāliem traucējumiem.

Transporta attīstības pamatnostādnes 2014.-2020. gadam (turpmāk - TA pamatnostādnes) (Saeima, 2013f) ir nozīmīgs dokuments, it sevišķi lauku reǵionu kontekstā, jo nosaka mērḳus sabiedriskā transporta nodrošināšanai arī pagastos un novados. Personu ar invaliditāti situācijas uzlabošana dokumentā nav īpaši izcelta. 
Likumu un MK noteikumu pārskats, kas attiecas uz personu ar invaliditāti tiesībām un sociālo pakalpojumu iespējām, pievienots 2. pielikumā "Likumi un MK noteikumi, kas stiprina personu ar invaliditāti tiesības".

Šajā nodaḷā skatīti politikas veidošanas dokumenti, kas nozīmīgi personu ar invaliditāti cilvēktiesību un pamatbrīvību realizēšanai. Papildus 2. pielikumā pievienots likumu un MK noteikumu pārskats. Skatītie politikas dokumenti ir svarīgi, jo atspogulı politisko diskursu un norāda uz esošo un plānoto rīcību personu ar invaliditāti situācijas uzlabošanai. Politikas veidošanā liela nozīme ir starptautiskajiem līgumiem un politikas pārmaiṇām, kas tiek īstenotas ar Eiropas Savienības (turpmāk - ES) fondu atbalstu. Aktuālajam ES atbalstam, kas tiek sniegts sociālajai uzṇēmējdarbībai, vajadzētu sekmēt personu ar invaliditāti iesaisti darba tirgū, savukārt DI plāna īstenošanai vajadzētu veicināt sociālo pakalpojumu un nepieciešamās infrastruktūras pieejamību, kā arī sabiedrības izpratni par personu ar invaliditāti situāciju. Politikas veidošanas dokumentos ir atrunāti principi, ka veicina personu ar invaliditāti situācijas uzlabošanu. Labākai politikas realizēšanas uzraudzībai būtu nepieciešams nodrošināt pārmaiṇu monitoringu.

\section{Personu ar invaliditāti vajadzības}

Šajā nodậā sniegts neliels ieskats vajadzību tipologiijā saskaṇā ar Ābrahama Maslova (Abraham Maslow) (Maslow, 1943; Maslow, 1954) motivācijas teoriju, tam seko veiktā empīriskā pētijuma metodologijas apraksts un detalizēts pètījuma rezultātu apraksts un analīze.

SEMPRE projekta vajadzībām tika apzinātas personu ar invaliditāti vajadzības Grobiṇas, Priekules un Rucavas novadā un Liepājā. Sākotnēji vajadzību apzināšana bija plānota kā atbalstošs mikroprojektu izveides instruments SEMPRE projekta ietvaros. Izpētē tika konstatētas materiālās, emocionālās un sociālās vajadzības, kas savstarpēji var mijiedarboties un būt saistītas. Paturot prātā, ka personu ar invaliditāti vajadzības ir tādas pašas kā citiem cilvēkiem, formulētas problēmsituācijas, ar ko saskaras šie cilvēki. Empīrisko datu iegūšanai veiktas intervijas ar personām ar invaliditāti, sociālo pakalpojumu sniedzējiem un institūciju pārstāvjiem. Apzināts identificēto vajadzību un problēmu 
spektrs. Ne katra persona ar invaliditāti sastopas ar visām aprakstītajām problēmsituācijām vajadzību realizēšanā.

\section{Vajadzības Maslova motivācijas teorijā}

Vajadzību apzināšana ir jautājums, kas vairāk pētīts ekonomikā un psiholog̣ijā, nevis sociologijā. Viena no zināmākajām teorijām, kas piedāvā vajadzību klasifikāciju un tiek izmantota arī sociolog̣ijā, ir amerikāņu psihologa un filozofa Ābrahama Maslova izstrādātā vajadzību struktūra, kas mūsdienās ierasti attēlota piramīdas veidā.

Maslovs (Maslow, 1943; Maslow, 1954) vajadzību tipologiju izveidoja, lai izprastu cilvēku motivāciju. Viņš vajadzības skata kā uzvedības un rīcības organizētāju - vajadzība, kas konkrētajā posmā indivīdam ir izteiktāka, nosaka viṇa izturēšanos. Vajadzības hierarhiski grupētas piecos līmeņos - (1) fiziolog̣iskās vajadzības; (2) drošība; (3) piederība, pieḳeršanās, mīlestîba; (4) cienna; (5) pašizpausme. Vēlākajos darbos Maslovs (Maslow, 1970) paplašina pašizpausmes vajadzības līmeni ar vēl trim vajadzībām - kognitīvajām, estētiskajām vajadzībām un ar transcendenci. Ja visām vajadzībām apmierināšana ir ierobežota, tad dominējošās ir fiziolog̣iskās vajadzības. Kad šĩ vajadzība sasniedz relatīvas apmierinātības līmeni, tā zaudē daḷu aktualitātes un indivīda uzvedība vērsta uz nākamās vajadzības - drošỉbas - apmierināšanu. Attiecīgi tālāk šāds motivācijas maiņas modelis attiecināms uz hierarhiski augstākām vajadzībām. Papildus Maslovs norāda uz izziņas un izpratnes kāri kā vajadzību hierarhijas mijiedarbīgu sistēmu. Vajadzību hierarhiskajā secībā ir iespējams kādas vajadzības trūkums vai pozīcijas maiņa attiecībā pret citām vērtībām. Vajadzības ir līdzās pastāvošas, vienlaicīgas, tomēr nav vienlīdz motivējošas. Apmierinātībai ar pamatvajadzībām vajadzētu būt lielākai nekā ar hierarhijā augstāk esošām vajadzībām, lai hierarhiski augstākstāvošās tiktu vairāk aktualizētas.

Maslova motivācijas teorija joprojām tiek izmantota un attīstīta tālāk, piemēram, vajadzību un subjektīvās labklājỉbas izpētē (Tay, Diener, 2011), dzīves kvalitātes izpētē (Hagerty, 1999), tehnologiju izmantošanas veicināšanas stratēgiiju izstrādē senioriem (Thielke et al., 2012). 
Šajā publikācijā īss ieskats Maslova motivācijas teorijā sniegts divu iemeslu dēḷ. Pirmkārt, lai apzinātu empīriskajā pētījumā izzināto personu ar invaliditāti aprakstìto vajadzību spektra nepilnības. Otrkārt, lai uzsvērtu, ka indivīdam nepieciešams nodrošināt zināmu apmierinātību ar pamatvajadzībām (piemēram, fiziologiskās vajadzības un drošỉba), lai tiktu īstenots uzvedības modelis hierarhiski augstāku vajadzību apmierināšanai (piemēram, piederība, pieḳeršanās, mīlestîba vai attiecīgi tālāk - cieņa un pašizpausme).

\section{Vajadzību apzināšanas metodologija}

Pētījumā izmantotas kvalitatīiās metodes; vajadzību apzināšana balstās uz informāciju, kas iegūta daḷēji strukturētās individuālās un grupu intervijās no personām ar invaliditāti un sociālo pakalpojumu sniedzējiem. Visas intervijas tika iepriekš norunātas un organizētas. Kā veiksmīgs respondentu sasniegšanas instruments jāizcel̦ sludinājuma ievietošana vietējā avīzē. Tas tika izmantots, organizējot grupas interviju ar personām ar invaliditāti Priekules novadā.

2016. gada jūnijā, jūlijā un augustā notika 11 tikšanās, kurās tika sasniegtas 49 kontaktpersonas: Priekulē (21. jūlijs, 5. augusts) 7 sociālā dienesta darbinieces, 11 cilvēki ar invaliditāti un 2 personas, kas aprūpē tuvinieku ar invaliditāti; Rucavā (4. augusts) 2 sociālā dienesta darbinieces, 1 cilvēks ar invaliditāti; Grobiņā (20. jūlijs) 4 darbinieki pansionātā "İĝ̣i”, pusceḷa mājās; Liepājā (2., 3. jūnijs) 8 iemītnieki septiņos grupu dzìvokḷos, grupu dzīvokḷu vadìtāja, psihiatriskās klīnikas "Piejūras slimnīca" vadītājs, 4 cilvēki, kas izmanto ratiṇkrēslu, un 1 persona ar kustỉbu traucējumiem, kas izmantoto spieķi, 7 cilvēki ar invaliditāti, kas darbojas Liepājas Diakonijas centra atbalsta grupā.

Pētijuma rezultātu aprakstā iekavās norādīta informācija par intervētajām personām - persona ir invaliditāti, institūcijas darbinieks, sociālā dienesta darbinieks. Tā izmantota arī citātu atsaucē. Šāda vispārināta atsauču forma ievērota ētisku apsvērumu dēḷ.

Visas intervijas bija izzinošas, intervētās personas labprāt sniedza atklātu un godīgu informāciju un veicināja problēmas aktualizāciju. Pētijuma autore pateicas visām intervijās iesaistītajām personām. 
1. tabula

Lauka darba pārskats

\begin{tabular}{|c|c|c|c|c|}
\hline $\begin{array}{c}\text { Intervijas } \\
\text { nr. }\end{array}$ & $\begin{array}{c}\text { Intervijas } \\
\text { vieta, datums }\end{array}$ & $\begin{array}{c}\text { Intervētās/-o } \\
\text { personas/-u } \\
\text { kategorija }\end{array}$ & Piezīmes & $\begin{array}{l}\text { Intervijas } \\
\text { dalībnieku } \\
\text { skaits }\end{array}$ \\
\hline 1. & $\begin{array}{l}\text { Liepāja, } \\
\text { 02.06.2016. }\end{array}$ & $\begin{array}{l}\text { Institūcijas } \\
\text { pārstāvis }\end{array}$ & $\begin{array}{l}\text { Valsts SIA "Piejūras } \\
\text { slimnīca" vadītājs }\end{array}$ & 1 \\
\hline 2. & $\begin{array}{l}\text { Liepāja, } \\
\text { 02.06.2016. }\end{array}$ & $\begin{array}{l}\text { Personas ar } \\
\text { invaliditāti }\end{array}$ & $\begin{array}{l}\text { Privātpersonas } \\
\text { izmanto palīgierīces, lai } \\
\text { pārvietotos }\end{array}$ & 5 \\
\hline 3. & $\begin{array}{l}\text { Liepāja, } \\
\text { 03.06.2016. }\end{array}$ & $\begin{array}{l}\text { Institūcijas } \\
\text { pārstāvis }\end{array}$ & $\begin{array}{l}\text { Liepājas grupu dzīvoklı } \\
\text { vadītāja }\end{array}$ & 1 \\
\hline 4. & $\begin{array}{l}\text { Liepāja, } \\
\text { 03.06.2016. }\end{array}$ & $\begin{array}{l}\text { Personas ar } \\
\text { invaliditāti }\end{array}$ & $\begin{array}{l}\text { Privātpersonas, kas ir } \\
\text { grupu dzīvokḷu iemītnieki }\end{array}$ & 8 \\
\hline 5. & $\begin{array}{l}\text { Liepāja, } \\
\text { 03.06.2016. }\end{array}$ & $\begin{array}{l}\text { Personas ar } \\
\text { invaliditāti }\end{array}$ & $\begin{array}{l}\text { Privātpersonas ar dažāda } \\
\text { veida funkcionāliem } \\
\text { traucējumiem }\end{array}$ & 7 \\
\hline 6. & $\begin{array}{l}\text { Grobina, } \\
20.07 .2016 .\end{array}$ & $\begin{array}{l}\text { Institūcijas } \\
\text { pārstāvji }\end{array}$ & $\begin{array}{l}\text { Valsts sociālās aprūpes } \\
\text { centra "Kurzeme” } \\
\text { direktors; direktora } \\
\text { vietniece; filiāles “Ilı́gi” } \\
\text { vadītāja; pusceḷa māju } \\
\text { vadītāja }\end{array}$ & 4 \\
\hline 7. & $\begin{array}{l}\text { Grobina, } \\
\text { 20.07.2016. }\end{array}$ & $\begin{array}{l}\text { Institūcijas } \\
\text { pārstāvji }\end{array}$ & $\begin{array}{l}\text { Valsts sociālās aprūpes } \\
\text { centra "Kurzeme" filiāles } \\
\text { "Ilı́gi" vadītāja; pusceḷa } \\
\text { māju vadītāja }\end{array}$ & 2 \\
\hline 8. & $\begin{array}{l}\text { Priekule, } \\
\text { 21.07.2016. }\end{array}$ & $\begin{array}{l}\text { Sociālā dienesta } \\
\text { darbinieki }\end{array}$ & $\begin{array}{l}\text { Priekules novada Sociālā } \\
\text { dienesta vadītāja un } \\
\text { darbinieces }\end{array}$ & 7 \\
\hline 9. & $\begin{array}{l}\text { Priekule, } \\
\text { 05.08.2016. }\end{array}$ & $\begin{array}{l}\text { Personas ar } \\
\text { invaliditāti un } \\
\text { personas, } \\
\text { kas aprūpē } \\
\text { tuvinieku ar } \\
\text { invaliditāti } \\
\end{array}$ & $\begin{array}{l}\text { Privātpersonas ar dažāda } \\
\text { veida funkcionāliem } \\
\text { traucējumiem, } \\
\text { divas personas } \\
\text { bez funkcionāliem } \\
\text { traucējumiem } \\
\end{array}$ & $11+2$ \\
\hline 10. & $\begin{array}{l}\text { Rucava, } \\
\text { 04.08.2016. }\end{array}$ & $\begin{array}{l}\text { Sociālā dienesta } \\
\text { darbinieki }\end{array}$ & $\begin{array}{l}\text { Rucavas novada Sociālā } \\
\text { dienesta vadītāja un } \\
\text { darbiniece }\end{array}$ & 2 \\
\hline 11. & $\begin{array}{l}\text { Rucava, } \\
\text { 04.08.2016. }\end{array}$ & $\begin{array}{l}\text { Persona ar } \\
\text { invaliditāti }\end{array}$ & $\begin{array}{l}\text { Privātpersona ar dažāda } \\
\text { veida funkcionāliem } \\
\text { traucējumiem }\end{array}$ & 1 \\
\hline
\end{tabular}




\section{Vajadzību analīze un sasaiste ar politikas dokumentiem}

Pētījumā tika konstatētas 13 vajadzību grupas, kur saskatīta problēmsituācija: (1) veselība un veselības aprūpe; (2) finanses; (3) dzīvesvietas kvalitāte, iespējas to uzlabot, sadzīves apstākḷi; (4) ikdienas darbu veikšana; (5) transports; (6) nodarbinātība; (7) darbnīcas; (8) brīvais laiks un dienas aprūpes centri; (9) sabiedrības attieksme; (10) bērnu aprūpe; (11) sociālie kontakti, ğimenes veidošana; (12) spēja darboties; (13) atkarību pārvarēšana. Katra minētā grupa skatīta atsevišķi, vispirms norādot, kurās intervijās tā ir parādījusies, formulējot problēmsituācijas un attiecīgās vajadzības, kas ar tām saistītas, un turpinājumā skatot politikas dokumentu un normativo aktu kontekstu.

\subsection{Veselība un veselības aprūpe}

Funkcionālie traucējumi var būt cieši saistīti ar noteiktām veselības problēmām un arī ar veselības aprūpi. Problēmsituācijas personu ar invaliditāti dzìvē, kas saistītas ar veselību un veselïbas aprūpi, parādās astoṇās intervijās - visās četrās intervijās ar institūcijas pārstāvjiem, vienā intervijā ar sociālā dienesta darbiniekiem un trīs intervijās ar personām ar invaliditāti.

Galvenās situācijas, problēmas un izaicinājumi, kas atklāti empīriskajā izpētē:

- papildu izmaksas līdztekus valsts nodrošinātajam veselības aprūpes finansējumam;

- veselības aprūpes profesionāļu un rehabilitācijas speciālistu pieejamība lauku reǵionos;

- transporta pieejamība un izmaksas, lai nokḷūtu pie veselības aprūpes profesionāļiem novada centrā un/vai pilsētā, atsevišķos gadījumos arī asistenta kā līdzbraucēja nepieciešamība;

- invaliditātes statusa kārtošana;

- DI plāns kontekstā (mērksgrupa: pilngadīgas personas ar garīga rakstura traucējumiem) - vajadzība pēc atgādinājuma un motivācijas lietot ārsta izrakstītos medikamentus.

Vajadzïbas:

- vajadzība pēc pieejama transporta uz veselības aprūpes iestādi un pēc asistenta kā līdzbraucēja; 
- vajadzība pēc vietējiem veselības aprūpes un rehabilitācijas profesionāliem;

- vajadzība tikt motivētam, saņemt atgādinājumu.

Veselība un veselības aprūpe ir viens no būtiskajiem aspektiem personu ar invaliditāti dzīēe. Te summējas (a) pats funkcionālā traucējuma fakts, kas var būt saistīts ar papildu veselības aprūpes nepieciešamību; (b) veselības aprūpes pieejamības problēma, ar ko saskaras ne tikai cilvēki ar invaliditāti; (c) papildus var būt arī vides pieejamības apgrūtinājums, kas izriet no funkcionālā traucējuma. Kā intervijā norāda sociālā dienesta darbinieks, "Nav ergoterapeitu, psihologu, laukos nav speciālistu. Ir trīs ğimenes ārsti, no kuriem divi ir pensijā. Procedūras, piemēram, dialīze, kur nav īpašais kopšanas pabalsts, ir trīs reizes nedēlā Liepājā. Atkal ir problēma - šoferis uz katru gadījumu riskē, jo pārvadā slimu cilvēku, kādam būtu jābrauc līdzi”.

Citā intervijā institūcijas darbinieks stāsta par līdzīgu problēmu: "Mediciniskajā rehabilitācijā trūkst speciālistu. Piemēram, fizioterapeits, jo tādai darba specifikai alga ir par zemu, par to samaksu grūti atrast speciālistu, sertificētu fizioterapeitu, kas par tādu naudu būtu ar mieru strādāt. Tas pats ar psihologu."

Intervijās personas ar invaliditāti uzsver, ka liela daļa ienākumu tiek tērēta medikamentu iegādei. Cilvēkiem ar psihiskām saslimšanām saistībā ar veselības aprūpi, atrodoties ārpus institūcijas, nepieciešama arī atbalsta funkcija, lai nodrošinātu izrakstīto medikamentu regulāru lietošanu: "Un, protams, svarīgi viņus atbalstìt. Mūsu pacientiem ir problēma, ka viņi slikti apzinās, ka viniem jālieto zāles. Tas ir jāatbalsta, jāatgādina. Tā ir problēma. Es nezinu, vai to var sabiedriska organizācija. Bet tas ir svarīgi īstenībā. Daudziem mūsu pacientiem tas pat ir izškiroši," - tā intervijā saka institūcija pārstāvis. Teiktais jāṇem vērā, domājot par DI plāna realizāciju un iespējamām sekām.

Sociālās aprūpes centra finansējums neațauj pilnveidot rehabilitācijas programmu, piemēram, iekārtot sensoru istabu, kas ir modernās mūsdienu tehnologijas, bet, lai iegādātos tehnologijas, trūkst līdzekḷu, intervijā saka institūcijas pārstāvji. Šobrīd DI plāna kontekstā liels uzsvars ir uz sabiedrībā balstītiem pakalpojumiem, tomēr nedrīkst aizmirst, ka ir personas ar invaliditāti, kas paliks institūcijās.

ANO Konvencijas īstenošanas pamatnostādnēs veselība ir viena no sociālās aizsardzības komponentēm, kas ir iekḷauta prioritārajos rīcības virzienos. 
Papildu izmaksas un gaidīšanas laiks veselības aprūpē ir problēmsituācija, kur risinājumu pieprasa arī Eiropas Komisija. Stratēégijas “Eiropa 2020" šobrīd aktuālajās rekomendācijās Latvijai (European Commission, 2017) noteikts, ka veselības aprūpē jāpaaugstina izmaksu efektivitāte un veselības aprūpes pieejamība, tai skaitā samazinot individuālos maksājumus (out of pocket payments) un ilgo gaidīšanas laiku.

Eiropas Komisijas 2017. gada augustā publicētajā ziṇojumā "Par veselības aprūpes reformu" (European Commission, 2017) ir minēti rezultāti, kas Latvijai sasniedzami līdz 2023. gadam. Lūk, daži no tiem: "gaidīšanas laiks līdz pirmreizējai ārsta speciālista konsultācijai nepārsniedz 3 mēnešus; gaidīšanas laiks līdz izmeklējumam (radiolog̣ijā) nepārsniedz vienu mēnesi; pacienta lídzmaksājuma daḷa samazinās" (European Commission, 2017, 66). Situācijas izvērtējumā ir minētas šobrīd esošās rindas pie speciālistiem: "Pieejamība pie speciālista (dienās) [avots: NVD dati]. Endokrinologs - 241; Gastroenterologs - 185; Ginekologs - 123; Neirologs - 155; Oftalmologs - 221; Urologs - 97" (European Commission, 2017, 63); šìs rindas būtu jāsamazina līdz 90 dienām. Nav uzskaitīiti visi speciālisti, tomēr minētie skaiți skaidri iezīmē problēmu, kurai pieprasīts risinājums. Stratēgijas "Eiropa 2020" rekomendācijas Latvijai ir saistošas.

Veselības aprūpes speciālistu piesaiste lauku regionos ir nozīmīgs faktors veselības aprūpes pieejamībai. Tāpat arī transports ir viens no aktuālajiem problēmjautājumiem. Tā kā iespēja izmantot transportu un nokḷūšana attālākā medicinas pakalpojumu saṇemšanas punktā bieži vien ir apgrūtinātas invaliditātes dēḷ, tad ḷoti svarīga ir veselības aprūpes speciālistu klātbūtne reǵionos.

ES fondu dalíbas programmas "Izaugsme un nodarbinātìba" viens no specifiskajiem atbalsta mērķiem ir "Uzlabot pieejamību ārstniecỉbas un ārstniecības atbalsta personām, kas sniedz pakalpojumus prioritārajās veselības jomās iedzīvotājiem, kas dzīvo ārpus Rīgas" (Veselības ministrija, 2016). Pasākumi, kas saistīti ar šo mērḳi, iekḷauti arī Veselïbas ministrijas ziṇojumā "Par veselības aprūpes reformu" (Veselības ministrija, 2017).

ES programmas "Izaugsme un nodarbinātība" atbalsta mērḳis "Uzlabot pieejamību ārstniecības un ārstniecības atbalsta personām, kas sniedz pakalpojumus prioritārajās veselības jomās iedzīvotājiem, kas dzīvo ārpus Rīgas" ar kopējo finansējumu 9960103 eiro paredz šādus rezultatīvos un iznākuma rādītājus: atbalstīto ārstniecības 
personu skaits, kuras strādā teritoriālajās vienībās ārpus Rīgas gadu pēc atbalsta saṇemšanas, - 506 (plānots 2023. g.) (rezultatīvais rādītājs); reğioniem piesaistìto ārstniecības personu skaits, kuras saṇēmušas atbalstu, lai veicinātu to piesaisti darbam teritoriālajās vienībās ārpus Rīgas, - 1420 (plānots 2023. g.) (iznākuma rādītājs) (Veselības ministrija, 2016). Medijos jau ir izskanējusi ziņa par iespējamajām kompensācijām mediḳu piesaistei darbam reǵionos (Latvijas Sabiedriskie Mediji, 2017; Strapcāne, 2017).

Personām ar invaliditāti lauku reǵionos nozīmīgs ir arī šis pašas programmas atbalsta mērḳis "Atbalstìt prioritāro (sirds un asinsvadu, onkologijas, perinatālā un neonatālā perioda aprūpes un garīgās veselības) veselības jomu veselības tīklu attīstîbas vadlīniju un kvalitātes nodrošināšanas sistēmas izstrādi un ieviešanu, jo īpaši sociālās atstumtības un nabadzības riskam pakḷauto iedzīvotāju veselības uzlabošanai" (Veselības ministrija, 2016). Tajā atbalstīts Nacionālā veselības dienesta projekts "Veselības tîklu attīstības vadlīniju un kvalitātes nodrošināšanas sistēmas izstrāde un ieviešana prioritāro veselības jomu ietvaros" (Nacionālais veselíbas dienests, 2016), kur viens no uzdevumiem ir "noteikt katra aprūpes līmeņa kompetenci un nepieciešamo tehnisko nodrošinājumu, tajā skaitā nosacijumus pakalpojumu pieejamības paaugstināšanai sociālās atstumtības un nabadzības riska grupām”. Tas attiecināms arī uz personu ar invaliditāti situāciju.

Veselības aprūpes sistēma būtu jāuzlabo (Bahmane, 2018), tā ir nozīmīga problēmsituācija ne tikai personām ar invaliditāti. Tomēr vides un sociālie šḳēešḷi un veselības aprūpes vajadzības, kas saistītas ar invaliditāti, šo problēmu padara smagāku tieši šai sabiedrības grupai. Tāpat arī savlaicīgas veselības aprūpes nepieejamība var būt invaliditātes attīstības iemesls.

\subsection{Finanses}

Problēmsituācijas, kas saistītas ar finansēm, konstatētas deviņās intervijās - trīs intervijās ar institūciju pārstāvjiem, abās intervijās ar sociālā dienesta pārstāvjiem un četrās intervijās ar personām ar invaliditāti.

Galvenās situācijas, problēmas un izaicinājumi, kas atklāti empīriskajā izpētē:

- pieejamo finanšu apjoms ne tikai personām ar invaliditāti, bet arī institūcijām; 
- DI plāna kontekstā (mērkgrupa: pilngadīgas personas ar garīga rakstura traucējumiem) - pieejamo finanšu plānošana (tajā pašā laikā ne vienmēr servisa galalietotājiem ir vēlme pēc šādas palīdzības); vāja izpratne par to, ko faktiski nozìmē līguma slēgšana un kredīta ņemšana.

Vajadzības:

- vajadzība uzlabot finansiālo stāvokli (darba pieejamība / nodarbinātības iespēja);

- vajadzība pēc palīdzības finanšu plānošanā.

Finanses ir nozīmīgs faktors dažādu vajadzību apmierināšanai ja ir pieejami finanšu resursi, tad iespējams iegādāties gan lietas, gan pakalpojumus, kas l̦auj veiksmīgāk realizēt savas cilvēktiesības un pamatbrīvības. Personas ar invaliditāti var uzlabot savu ekonomisko situāciju, strādājot algotu darbu. Veicot sociālās iemaksas, paaugstinās arī invaliditātes pensija.

Personas ar invaliditāti, kas ārstējas psihiatriskajā klīnikā, var paturēt visu savu invaliditātes pensiju, saņemt pajumti, èdienu, aprūpi. Personas ar invaliditāti, kas dzīvo sociālās aprūpes centrā (turpmāk SAC), patur vien $10 \%$, jo $90 \%$ invaliditātes pensijas tiek novirzìti kā finansējums institūcijai, bet viņi saņem pajumti, èdienu, aprūpi; cilvēki, kas dzīvo grupu dzīvokḷ,os, paši maksā par ēdienu, citām nepieciešamām precēm, dzīvokli (elektrību, piemēram). Tas faktiski rada situāciju, ka cilvēki, kas apzinās reālās ikdienas dzìves izmaksas, nevēlas pārcelies uz "brīvākām" institūcijām vai ārpus tām: "Nu un 7 eiro viniem paliek privātā naudiṇa mēnesī (dzìvojot SAC). Tas, starp citu, ir šḳērslis reizēm pierunāt iet uz pansionātu; viṇi jau rēḳina," intervijā norāda institūcijas pārstāvis. Viņš atzīmē arī, ka institūcijas klienti būtu priecīgi par iespēju piepelnīties; tādas iespējas ir tikušas meklētas, tomēr nav bijis iespējams realizēt.

Citas institūcijas pārstāvis norāda: "Tomēr klienti, kuriem pabalsts ir kādi 128 eiro - ja viniiem jāsamaksā par èdienu, citām nepieciešamajām precēm un vēl dzīvokli, tad tur nekas nepaliek. Vairāki uzskata, ka (grupu) dzīvokḷi ir par dārgu.” Te droši vien taisnīgāk būtu teikt, ka pieejamie finanšu līdzekḷi ir pārāk mazi. Iespēja atrast darbu un papildus pelnīt ir l̦oti nozīmìga gan saņemtās algas dēl, gan sociālo iemaksu dẹl, uz kā pamata iespējams paaugstināt invaliditātes pensiju.

Vienā no grupas intervijām persona ar invaliditāti rezumēja: "Liela daḷa (ienākumu) tiek tērēta zālēs.” Tādējādi pārējām nepieciešamajām 
precēm un pakalpojumiem paliek pavisam niecīgi ienākumi. Tas sasaistās arī ar jau minēto veselības aprūpes problēmsituāciju.

Cits būtisks finanšu aspekts ir spēja pārvaldīt finanšu līdzekḷus. Te atkal jāatzīmē DI plāna konteksts. Institūcijas pārstāve stāsta par gadījumu, kad puisis, sasniedzot pilngadību, pārcēlies uz grupu dzīvokli un saṇēmis savu uzkrājumu (vecāku zaudēšanas pabalsts, pensija). Vadītāja ieteikusi netērēt visu uzreiz, vēlējusies palīdzēt plānot izdevumus, tomēr rezultātā pret viṇu ierosināta krimināllieta, no Valsts policijas saņemts rīkojums, ka puisim ir rīcībspēja un to nedrīkst ierobežot. Rezultātā divu nedẹḷu laikā tika iztērēti 8400 eiro, tagad mantas, kas tika iegādātas, tiek pārdotas (jau ievērojami lētāk), jo ar invaliditātes pensiju 128 eiro apmērā viņš vairs nemāk izdzīvot.

Līdztekus jāskata arī cita problēmsituācija - līdzcilvēku attieksme un rīcība, jo ir gadījumi, kad personu ar garīgās attīstības traucējumiem uzticēšanos izmanto, lai iegūtu tos finanšu lïdzekḷus, kas viņiem ir pieejami. Ir svarīgi tam pievērst uzmanību un mazināt iespējamos riskus, realizējot DI plānu.

2016. gadā Latvijā ir 74501 invaliditātes pensijas saṇēmējs. Pensiju saņēmēju skaita sadalījums 2016. gadā pēc pensijas vidējā piešķirtā apjoma, pamatojoties uz CSP datiem (Centrālā statistikas pārvalde, 2017b), atspoguḷots 2. tabulā.

Lielākais pensijas saṇēmēju skaits - 11332 personas - ir ar pensiju robežās no 60,01 līdz 70,00 eiro (skatot 2. tabulu, jāṇem vērā, ka intervāls pensiju apjomam pie lielākām summām pieaug līdz 50 un 100 eiro). Tas skaidrojams ar noteikto invaliditātes pensiju apjomu un nosacijumiem. Pensiju apjoms atkarīgs no

- pieškirtās invaliditātes grupas;

- cilvēka vidējās apdrošināšanas iemaksu algas, ko nosaka par jebkuriem 36 mēnešiem pēc kārtas pēdējo 5 gadu laikā pirms invaliditātes pensijas piešķiršanas;

- cilvēka individuālā apdrošināšanas stāža;

- maksimāli iespējamā apdrošināšanas stāža, kuru nosaka no 15 gadu vecuma līdz likumā noteiktā pensijas vecuma sasniegšanai (Labklājỉbas ministrija, b.g.b).

Cilvēks, par kuru noteiktajā laika posmā nav veiktas sociālās apdrošināšanas iemaksas vai kurš nav strādājis algotu darbu, saṇem pensiju atbilstoši pieškirtajai invaliditātes grupai minimālajā apmērā. 
2. tabula

Invaliditātes pensiju saṇēmēju skaita sadalījums pēc pensijas vidējā piešķirtā apmēra 2016. gadā

\begin{tabular}{|c|c|c|}
\hline & Pensijas apjoms (eiro) & $\begin{array}{c}\text { Invaliditātes pensijas } \\
\text { san̄ēmēju skaits }\end{array}$ \\
\hline Po16 & Pensiju san̄ēmēju kopskaits & 74501 \\
\hline Intervāls 10 eiro & $60,01-70,00$ & 260 \\
\hline Intervāls 10 eiro & $70,01-80,00$ & 11332 \\
\hline Intervāls 10 eiro & $80,01-90,00$ & 5460 \\
\hline Intervāls 10 eiro & $90,01-100,00$ & 3446 \\
\hline Intervāls 10 eiro & $100,01-110,00$ & 5462 \\
\hline Intervāls 10 eiro & $110,01-120,00$ & 2527 \\
\hline Intervāls 10 eiro & $120,01-130,00$ & 3315 \\
\hline Intervāls 10 eiro & $130,01-140,00$ & 2800 \\
\hline Intervāls 10 eiro & $140,01-150,00$ & 3480 \\
\hline Intervāls 50 eiro & $150,01-200,00$ & 2405 \\
\hline Intervāls 50 eiro & $200,01-250,00$ & 14271 \\
\hline Intervāls 50 eiro & $250,01-300,00$ & 7930 \\
\hline Intervāls 100 eiro & $300,01-400,00$ & 5203 \\
\hline Intervāls 100 eiro & $400,01-500,00$ & 3277 \\
\hline & $>500,01$ & 1550 \\
\hline
\end{tabular}

Avots: Pensiju saṇēmēju skaita sadalījums pēc pensijas vidējā piešķirtā apmēra (Centrālā statistikas pārvalde, 2017b).

Tā ir:

- 3. invaliditātes grupai: 64,03 eiro mēnesī, bet invalīdam kopš bērnības - 106,72 eiro;

- 2. invaliditātes grupai: 89,64 eiro, invalīdam kopš bērnības 149,41 eiro;

- 1. invaliditātes grupai: 102,45 eiro, invalīdam kopš bērnības 170,75 eiro (Labklājības ministrija, b.g.b).

Finanšu problēmjautājums ir cieši saistīts ar nodarbinātības jautājumu. 2016. gadā invaliditātes noteikšanas ekspertīze pirmreizēji veikta 18547 personām, no tām 66,7\% jeb 11279 personas bija nestrādājošas (VDEĀVK, 2017). Tas nenozīmē, ka šie cilvēki nekad nav 
veikuši sociālās apdrošināšanas iemaksas, invaliditātes pensijas apjomu nosaka par jebkuriem 36 mēnešiem pēc kārtas pēdējo 5 gadu laikā.

Viens no ANO Konvencijas (Saeima, 2013a) isstenošanas pamatnostādṇu rezultatīvajiem rādītājiem ir "Personu ar invaliditāti skaits (\%), kuru ienākumi nepārsniedz nabadzības riska sliekšņa līmeni” (Saeima, 2013a, 48.-49.); par bāzes gadu ņemts 2011. gads (19,4\% no iedzīvotāju kopskaita). Mērḳis - 2017. gadā samazināt rādītāju līdz 15\% un 2020. gadā rādītāju turpināt samazināt. Saskaṇā ar CSP 2017. gadā publicētajiem datiem (Centrālā statistikas pārvalde, 2017b) 2011. gadā kopējais nabadzības riskam paḳ̣auto iedzìvotāju skaits bija 19,2\%, 2015. gadā tas pieaudzis līdz 21,8\%.

Valsts sniegtais atbalsts cilvēkiem ar invaliditāti ir viens no nevienlīdzības mazināšanas rīkiem. Pieejamais atbalsts noteikts atbilstoši invaliditātes grupai, kā arī funkcionālo traucējumu veidam. Ir pieejami pabalsti, piemēram, valsts sociālā nodrošinājuma pabalsts (MK, 2009c), îpaši atbalsta pasākumi personām ar redzes invaliditāti, kustību traucējumiem, garīgās attīstības traucējumiem. Labklàjības ministrija ir publicējusi apkopotu sarakstu par materiālā atbalsta iespējām, pieejamo atvieglojumu klāstu, informāciju par asistenta pakalpojumu pašvaldībā cilvēkiem ar invaliditāti, par sociālo rehabilitāciju, tehniskajiem palīglīdzekḷiem, profesionālo rehabilitāciju (Labklājỉbas ministrija, b.g.c) atbilstoši spēkā esošajiem likumiem un MK noteikumiem (skat. 1. pielikumu).

Pieejamo finanšu plānošana ir vēl viens aspekts finanšu kontekstā. Ne tikai pieejamais līdzekḷu apjoms, bet arī prasme ar tiem rìkoties nosaka rezultātu. Te īpaša vērība jāvelta cilvēkiem ar invaliditāti, kuru funkcionālie traucējumi var būt apgrūtinājums finanšu plānošanā. Saistībā ar DI plāna realizāciju ir paredzēts uzsākt mentora pakalpojuma sniegšanu pašvaldībās - "Darbības programmas "Izaugsme un nodarbinātība" specifiskā atbalsta mērķa "Palielināt kvalitatīvu institucionālai aprūpei alternatīvu sociālo pakalpojumu dzīvesvietā un ğimeniskai videi pietuvinātu pakalpojumu pieejamību personām ar invaliditāti un bērniem" pasākuma "Deinstitucionalizācija" istenošanas noteikumi” (MK, 2015). Saskaņā ar šiem MK noteikumiem mentora pakalpojums būtu pieejams cilvēkiem, kuri ir iekḷauti DI programmā; ārpus pakalpojuma pieejamības paliek tie, kuru DI programmā nav.

Skatot jautājumu par rīcību ar finanšu līdzekḷiem, jāṇem vērā arī citu sabiedrības locekḷu ietekme - likumīga un nelikumīga. Gan 
reklāma, gan citas pārdošanas aktivitātes var veicināt pirkuma, līzinga, naudas aiznēmuma līguma neapdomīgu parakstǐšanu, kuras sekas cilvēks ar invaliditāti (te runa par garīgās attīstības funkcionāliem traucējumiem) neapzinās. Lìdztekus iespējama arī l̦aunprātīga šo cilvēku izmantošana, izkrāpjot pieejamos finanšu līdzekḷus vai citu ipašumu. Iekšlietu ministrijas politikas dokumentos (Iekšlietu ministrija, b.g.) šobrīd nav tādu plānošanas dokumentu, kas attiektos tieši uz cilvēku ar invaliditāti situāciju. N̦emot vērā DI plāna aktualitāti, būtu nepieciešama mērḳtiecīga situācijas kontrole un uzraudzība.

\subsection{Dzīvesvietas kvalitāte}

Problēmsituācijas, kas saistītas ar dzīvesvietas kvalitāti, iespējām to uzlabot, remontēt, ar dzìves apstākḷiem, konstatētas septiṇās intervijās - trīs intervijās ar institūciju pārstāvjiem, vienā intervijā ar sociālā dienesta pārstāvjiem un trīs intervijās ar personām ar invaliditāti.

Galvenās situācijas, problēmas un izaicinājumi, kas atklāti empīriskajā izpētē:

- pašvaldībām nav pieejams kvalitatīvs dzīvojamais fonds, ko varētu izmantot;

- finansiālais ieguldijums remontdarbos (materiāli u. tml.);

- nespēja fiziski veikt nepieciešamos remontdarbus;

- nespēja sadzīvot ar istabas biedriem.

Vajadzības:

- vajadzība pēc brīvprātīgā darba, remontdarbu materiāliem;

- vajadzība izmitināt atsevišḳi cilvēkus ar garīgu atpalicību un psihiskām saslimšanām (grupu dzīvokḷos, sociālās aprūpes centros).

N̦emot vērā skatìto finanšu problēmsituāciju, jāsaprot, ka ir personas ar invaliditāti, kas nevar ațlauties iegādāties vai īrēt labas kvalitātes dzīvesvietu un nevar aț̣auties arī veikt remontu. "Par invalīdu vajadzībām vispirms ir jāsāk ar dzīvesvietu: durvis šauras, ūdens ārā, tualete ārā, mazgājas bḷodā. Ja nav radinieku, tuvinieku, kas rūpējas, tad ir ḷoti grūti," norāda sociālā dienesta darbinieks. Sociālie dzīvokḷii ne vienmēr ir pieejami, un tajos bieži vien netiek piedāvāta vide, kas būtiski uzlabotu situāciju. Tomēr persona ar invaliditāti intervijā ir priecīga par dzīvokli, kas saņemts ar pašvaldības atbalstu, un stāsta, kā grasās to iekārtot, taču ir skaidrs, ka tas prasīs darbu un līdzekḷus: 
"Man būs savs dzīvoklis. Tur remonts jātaisa. Spēcīgs. Tur podu vajag, vajag izlietni.” Jāṇem vērā, ka persona ar invaliditāti var arī fiziski nespēt vai nemācēt veikt nepieciešamos remontdarbus, tad strādnieku noalgošanai nepieciešami papildu finanšu līdzekḷi.

Institūcijas pārstāvis stāsta par gadījumu, kad cilvēks ir bez pases, bez deklarēšanās, bez dzīvesvietas: "Viena no problēmām ir pavisam primitīva, ka viniem nav ìsti dzīvesvietas. Sava stāvokḷa dēl savu dzīvesveidu zaudējuši, kas ir zaudējuši dzīvokli. Mums ir tāda viena kundze, kur dzīvoja bez pases ilgus gadus, divdesmit gandrīz. Bez pases, bez deklarēšanās. Ne jau kaut kur mežā - Liepājā. Slims cilvēks. Viņš dzīvoja savā pasaulē. Un, ja pārējiem tava dzīve neinteresē, tad... Mès vinu mēgeinām tagad legalizēt." Arī šādi var atklāties dzīvesvietas problēmjautājums.

Dzivokḷa biedrs var sniegt iespēju, ka viens otru pieskata, tomēr ne vienmēr cilvēki var labi sadzīvot. Grupu dzivokḷ los sākotnēji bija plānots, ka visi dzīvos istabināa pa divi, tomēr rezultātā bija lielas domstarpības. Institūcijas pārstāvis uzsver, ka nedrīkst izmitināt vienā istabā personu ar garīgās attīstības traucējumiem kopā ar personu ar psihisku saslimšanu. No līdzšinējās pieredzes pārstāvis secina, ka vislabāk tomēr novērtēt cilvēka gatavību patstāvīgai dzīvei, ja viṇam ir atsevišķa istaba grupu dzìvoklī.

Novadu centros ir pieejami higiēnas centri, kur var nomazgāties, izmazgāt drēbes, saṇemt nepieciešamo apgeērbu no lietoto apgeērbu krātuves.

Valsts atsevišķos gadījumos personai ar invaliditāti sniedz atbalstu mājokḷa pielāgošanai (MK, 2010a). ANO Konvencijas īstenošanas pamatnostādnēs ir rezultatīvais rādītājs "Pilnveidots atbalsts mājokḷa pielāgošanai", kur uzskaites rādītājs ir "Personu ar invaliditāti skaits, kuras saṇem atbalstu mājokḷa pielāgošanai”; 2011. gadā (bāzes gads) atbalstu mājokḷa pielāgošanai saṇēma viena persona; 2017. gadā 100 personas; 2020 . gadā atbalsta saṇēmēju skaits palielināsies (Saeima, 2013a). MK noteikumi "Noteikumi par kārtību, kādā personas ar invaliditāti saṇem atbalstu mājokḷa pielāgošanai, un atbalsta saṇemšanas nosacijumiem" (MK, 2010a), kas izdoti saskaṇā ar Invaliditātes likumu, paredz atbalsta sniegšanu mājokḷa pielāgošanai personām ar I grupas invaliditāti, personām ar II grupas redzes vai dzirdes invaliditāti un noteiktos gadījumos līdz 18 gadu vecumam.

MK noteikumi (MK, 2010a) faktiski paredz atmaksu par ieguldītajiem līdzekḷiem, kas attiecināmi uz atbalstu. Tas nozīmē, ka cilvēkam 
ar invaliditāti pašam ir jāmeklē finanšu iespējas (piemēram, jāņem kredīts), lai realizētu šo mājokḷa pielāgošanas atbalstu. Tas vieš arī zināmu nedrošību, jo, ja ir kādas neprecizitātes vai neatbilstība prasībām, tad ieguldītie lìdzekḷ var netikt attiecināti uz atbalstu un atmaksa netiek sañemta.

Saistībā ar DI plāna realizāciju ir plānotas vērienīgas investīcijas infrastruktūras attīstībā, kas ietver arī, piemēram, grupu dzīvokḷu izbūvi. DI plāna realizācijā iesaistītajiem cilvēkiem ar invaliditāti, saskaņā ar rīcības plānu DI īstenošanai (Saeima, 2015), dzīvesvietas risinājumi tiks rasti plāna ietvaros kā pašvaldību projekti. Te paredzama ievērojama nevienlīdzība DI iesaistīto un DI neiesaistīto situācijā.

\subsection{Ikdienas darbu veikšana}

Problēmsituācija, kas saistīta ar mājsaimniecības ikdienas darbu veikšanu, konstatēta vienā grupas intervijā ar personām ar invaliditāti.

Galvenās situācijas, problēmas un izaicinājumi, kas atklāti empīriskajā izpētē:

- nespēja fiziski veikt mājsaimniecỉbā nepieciešamos darbus tīrīt, mazgāt logus, ienest malku apkurei, iepirkties.

Vajadzības:

- vajadzība pēc palīdzības ikdienas iepirkumu veikšanai;

- vajadzība pēc palīdzības mājas apkopes dabu veikšanai.

Personas ar invaliditāti var saskarties ar problēmu, ka nespēj veikt saimniecỉbā nepieciešamos darbus - tīrīt, mazgāt logus, ienest malku apkurei, iepirkties. Ir vajadzīga palīdzība. Šo situāciju labi ilustrē sarunas fragments no grupas intervijas ar cilvēkiem ar invaliditāti: $Z$ (persona ar invaliditāti) (pasaka ar grūtībām, atbildot uz jautājumu, kāda ir viṇai šobrīd lielākā vajadzība, ko nevar realizēt): "Man griesti jākrāso." $\mathrm{X}$ (persona ar invaliditāti): “Tā jau ir maza problēma!” N (persona ar invaliditāti): "Nē, tā ir liela problēma, piemēram, remonts. Tā ir liela problēma. Tur vajadzīgi līdzekḷi, tur vajadzīgi cilvēki. Kurš tev ies pa velti strādāt? Katrs grib ar savu darbu nopelnīt." O (persona ar invaliditāti): "Re kur, kundze teica "es nevaru griestus nomazgāt", es nevaru arī logus nomazgāt."

Te runa ir par vēlmi dzīvot cilvēka cienīgos dzìves apstākḷos. Sakopta vide arī ir daļa no tiem, tomēr var būt, ka cilvēks funkcionālo spēju ierobežotības dēḷ nespēj sakopt savas mājas. 
Ikdienas darbi, kas cilvēkam ar invaliditāti var būt neizpildāmi vai kas var prasît ievērojami vairāk laika un spēka, ir paveicami ar aprūpētāja (aprūpes mājās) vai asistenta pakalpojuma palīdzību. Aprūpētāja pakalpojumu reglamentē Sociālo pakalpojumu un sociālās palīdzības likums (Saeima, 2002a), savukārt asistenta (pavadoṇa) pakalpojumu Invaliditātes likums (Saeima, 2010a). Asistenta pakalpojums vairāk attiecas uz ārpus mājas aktivitātēm, nokḷušsanu kādā vietā un pēcāk atpakal mājās. Asistents vairāk palīdz, atbalsta kādas darbības veikšanā, kamēr aprūpētājs vairāk aprūpē to, kurš izdara nepieciešamo darbỉbu. Tādējādi ir virkne situāciju un nepieciešamību (piemēram, iepirkšanās), kas var tikt risinātas gan kā aprūpes pakalpojums, gan ar asistenta palīdzību. Ikdienas mājas darbi lielākoties attiecināmi uz aprūpētāju: "Aprūpētājs ir nodarbināts klientu dzīves vietās un sociālās aprūpes institūcijās, kur veic klientu aprūpi sociālā darba speciālistu uzraudzībā. Aprūpētājs palīdz personām, kuras pašas sevi nevar aprūpèt, ievērot higiēnu, sagatavot un uzņemt èdienu, uzkopt telpas, apgādāt ar pirmās nepieciešamības precēm, kà arī uzturēt klienta saistību ar apkārtējo vidi." (Izglītības un zinātnes ministrija, 2004)

Sociālo pakalpojumu un sociālās palīdzības likums noteic, ka aprūpe mājās ir "pakalpojumi mājās pamatvajadzību apmierināšanai personām, kuras objektīvu apstākḷu dēḷ nevar sevi aprūpēt”. Aprūpi mājās nodrošina pašvaldības sociālais dienests atbilstoši konkrētās pašvaldības saistošajiem noteikumiem par sociālo pakalpojumu piedāvājumu.

Saņemtais atbalsts mājsaimniecībā veicamo darbu izpildē personām ar invaliditāti ir atkarīgs no katras pašvaldības saistošajiem noteikumiem par sociālo pakalpojumu piedāvājumu ar izrietošajiem riskiem un nevienlīdzību, jo pašvaldībām ir atšķirīgi finanšu resursi un būtiski var atškirirties vēlme un ieinteresētỉba pieejamo finansējumu virzīt personu ar invaliditāti atbalstam.

\subsection{Transports}

Problēmsituācija, kas saistìta ar transportu, konstatēta trīs intervijās - vienā intervijā ar sociālā dienesta pārstāvjiem un divās intervijās ar personām ar ìpašām vajadzībām.

Galvenās situācijas, problēmas un izaicinājumi, kas atklāti empīriskajā izpētē: 
- attālums no dzīvesvietas līdz sabiedriskajam transportam atseviškās vietās lauku reǵionos;

- sabiedriskā transporta pieejamība cilvēkiem, kas lieto ratiṇkrēslu;

- sabiedriskā transporta vadītāja un citu sabiedriskā transporta lietotāju attieksme pret cilvēku ar invaliditāti.

Vajadzības:

- vajadzība atjaunot iespēju izmantot skolēnu autobusu maršrutos, kur citi sabiedriskā transporta pakalpojumi netiek nodrošināti;

- vajadzība pēc īpaši pielāgota transporta;

- vajadzība pēc sabiedriskā transporta vadītāja un citu sabiedriskā transporta lietotāju cieņas un atbalsta.

Transporta pieejamība ir nozīmīga gan kā sabiedrībā balstīts pakalpojums, gan arī kā citu pakalpojumu saṇemšanas nosacījums: "Liela problēma - transports. Pilsētā transports ir, bet laukos - nav. Ja ir, nevar iekāpt. Šoferi nepalīdz. Tas, ka nav transports, rada citas grūtības, piemēram, cilvēki netiek pēc pārtikas pakām. Agrāk varēja izmantot skolēnu autobusus. Tagad nevar. Pārvadātājs neatḷauj, uzskata, ka biznesam tiek atñemti klienti, draud ar sodiem (skolēnu autobusu) šoferiem. Tomēr sabiedriskais transports netiek nodrošināts. Ir vietas, kur līdz pieturai ir daudz kilometru, kur skolēnu autobuss ir vienīgā saikne, bet arī tur nel̦auj," saka sociālā dienesta pārstāvis. Arī personas ar invaliditāti uzsver to pašu problēmu: "Un otrais, tagad vēl viens nāk sāpīgs jautājums. Man autobuss iet - trīs kilometri aiz pieturas dzīvoju. Vajag rast iespēju valdībā, lai lemj, ka garām braucošais skolēnu autobuss cilvēkiem, vai tas ir invalīds vai veca tante, vai jūs, vai citi, l̦autu braukt ar skolēnu autobusu (ar uzsvaru) līdz sabiedriskam transportam."

Pierobežas novadi ir sliktākā situācijā - tie atrodas transporta ķēdes galā, jo tur nav cauri kursējošu maršrutu uz tālāku novadu centriem. Ir arī gadījumi, kad ir panāktas vienošanās par iespēju ar noteiktiem nosacijumiem skolēnu autobusu izmantot. Tomēr, ja šādas iespējas nav, tad problēma ir īpaši aktuāla tieši mazāk nodrošinātajām sabiedrības grupām, kam nav sava privātā transporta.

Saistībā ar sabiedriskā transporta pieejamību cilvēkiem ar invaliditāti lauku reǵionos būtiski ir šādi politikas veidošanas dokumenti: Satiksmes ministrijas "Transporta attīstības pamatnostādnes 
2014.-2020. gadam” (Saeima, 2013f) un VARAM “Regionālās politikas pamatnostādnes 2013.-2019. gadam” (Saeima, 2012). Abi dokumenti paredz nodrošināt transporta infrastruktūras un sabiedriskā transporta sakārtošanu un attīstību lauku teritorijās atbilstoši NAP (Saeima, 2013b) rīcības virziena "Pakalpojumu pieejamība līdzvērtīgāku darba iespēju un dzīves apstākḷu radīšanai” uzdevumiem.

Intervijās izskan, ka sabiedriskais transports ir problēma cilvēkiem, kas izmanto ratiņkrēslu, jo visi autobusi nav aprīkoti ar nolaižamo grīdu. Liepājā tiek minēti gadījumi, kad autobuss ir aprīkots ar zemo grību, bet šoferis to nenolaiž, kaut arī cilvēks ratiṇkrēslā gaida. Šoferi mēdz būt nepieklājīgi, aizskaroši.

Par terminiem sabiedriskā transporta pielāgošanai, lai personām ar funkcionāliem traucējumiem atvieglotu ieḳ̂ū̌šnu sabiedriskajā transportā un nodrošinātu šo personu pārvadāšanu, jāskata MK noteikumi "Sabiedriskā transporta pakalpojumu sniegšanas un izmantošanas kārtība": "Sabiedriskajam transportlīdzeklim jābūt pielāgotam normativajos aktos par transportlīdzekḷu izgatavošanu noteiktajām tehniskajām prasībām, lai personām ar funkcionāliem traucējumiem, grūtniecēm un personām ar maziem bērniem (tai skaitā ar bērnu ratiņiem) atvieglotu iekḷūšanu sabiedriskajā transportlīdzeklī un nodrošinātu šo personu pārvadāšanu." (MK, 2012b, 17. punkts)

Termiṇi atrunāti šo noteikumu 133., 134., 135. un 136. punktā, līdz 2024. gada 1. janvārim paredzot visu 17. punktā minēto prasību izpildi pilnā apmērā.

Pašvaldībām vajadzības gadījumā ir iespēja lemt par ārpakalpojuma pirkšanas nepieciešamību vai iespēju iegādāties piemērotu transporta līdzekli sociālā dienesta sniegto pakalpojumu ietvarā, tomēr ne viena, ne otra nav obligāta prasība.

Intervijās atklājas, ka sabiedriskajā transportā cilvēkiem ar redzes invaliditāti kḷuvis sarežğìtāk - agrāk bija jābūt līdzi apliecībai, ko, ja kontrole prasīja, uzrādīja; tagad ir obligāti jāuzrāda šoferim apliecība, lai saņemtu brīvbil̦eti. Cilvēkam, kas neredz, tas ir sarežğìti.

Transporta jomā būtisks atbalsta pasākums ir iespēja noteiktām sabiedrības grupām izmantot noteiktus sabiedriskā transporta pakalpojumus bez maksas. Personas ar I un II grupas invaliditāti, bērni ar invaliditāti, kā arī personas, kuras pavada personu ar I grupas invaliditāti vai bērnu ar invaliditāti, drīkst pārvietoties reǵionālajos starppilsētu maršrutos, regiionālajos vietējas nozīmes maršrutos vienā 
administratīvajā teritorijā, kā arī sabiedriskajā transportā pilsētas nozīmes maršrutos bez maksas (Satiksmes ministrija, b.g.).

\subsection{Nodarbinātība}

Problēmsituācija, kas saistīta ar nodarbinātību, konstatēta septiņās intervijās - trīs intervijās ar institūcijas pārstāvjiem, divās intervijās ar sociālā dienesta pārstāvjiem un divās intervijās ar personām ar invaliditāti.

Galvenās situācijas, problēmas un izaicinājumi, kas atklāti empīriskajā izpētē:

- bezdarbs kā problēma;

- maz iespēju gūt papildu ienākumus, iegūt vai paaugstināt darba stāžu, palielināt pensijas apjomu;

- nepieciešamība pēc iespēja saturiski piepildìt dienu ar jēgpilnu nodarbi.

Vajadzības:

- vajadzība pēc mērḳtiecīgām mācībām, kas orientētas uz konkrētu darbavietu;

- vajadzība attīstīt sociālo uznēēmējdarbību;

- vajadzība pēc atbalstošas likumdošanas (gan Darba likuma nosacījumi, gan Sociālās uzṇēmējdarbības likums).

Nodarbinātība ir problēmjautājums, kas cieši saistīts ar finanšu situācijas uzlabošanu, bet ne tikai ar to. Būtiska ir arī nodarbinātības loma pašapziņas veidošanā un iespējā saturiski piepildīt dienu ar jēgpilnu nodarbi. Tai pašā laikā darbs kā paradums ir jāiemācās, jāapgūst; to norāda institūcijas pārstāvis: "Jā, dabūt saprast, kāda ir dzīve, ka ir kaut kas jādara. It sevišḳi jau institūciju bērni. Viṇi ir izauguši tā, ka viņi nesaprot, ka kaut kas ir jādara. Viņiem tā doma bieži vien ir tāda - kā dabūt kaut ko tāpat vien, neko nedarot."

Personas ar invaliditāti saskaras ar bezdarba problēmu; konkurencē ar citiem darba meklētājiem viṇi ir neizdevīgākā pozīcijā: "Laukos jau visi par visiem vairāk vai mazāk zina. Nevar noslēpt, ka ir grupa," saka persona ar invaliditāti, kam nav izdevies savā novadā atrast darbu. Teiktais sasaucas ar citā novadā sacìto: "Ja ir darbs, kurā vajag mizot kartupel̦us, dodiet - es samizošu!” Tad runā kā darba devējs: "Bet kāpēc mums tevi jāñem? Tu esi invalīds. Ja tu sev iegriezīsi, mums ir jāuzn,emas atbildība." 
Par mācību programmu trūkumu intervijās būtiskas sūdzības neizskan. Tie, kas vēlas, atrod iespēju piedalìties mācību programmu apguvē; te atkal kā nozīmīgs parādās transporta jautājums. Tāpat arī būtisks ir motivācijas jautājums, uzmundrinājuma, ierosinājuma nepieciešamìba. Cits ar mācībām saistīts jautājums ir par to, ka arī pēc mācībām nodarbinātības problēma vēl joprojām pastāv. Kā īsi formulējusi persona ar invaliditāti: "Diplomi krājas kaudzē, bet darbu atrast nevar."

Personas ar invaliditāti izsaka vēlmi iesaistīties darba tirgū aktīvāk, nekā šobrīd iespējams, it sevišḳi savā novadā, tuvu dzīvesvietai; cilvēki apzinās, ka transporta izdevumi par nokḷušsanu darbā un no tā atpakal mājās var veidot būtisku daļu no atalgojuma. Tāpat nokḷū̌sana attālākā darbavietā prasa laiku, kas ir svarīgs arguments, it sevišḳi tiem cilvēkiem, kam ir bērni, par ko arī jārūpējas.

Intervijās ar sociālā dienesta un institūciju pārstāvjiem sociālā uzņēmējdarbība tiek minēta kā viens no iespējamiem risinājumiem; kā vēl viens risinājums nodarbinātîbas jautājumā minētas darbnīcas, kas varētu veicināt pašnodarbinātību.

Personu ar invaliditāti nodarbinātība ir viens no četriem prioritārajiem virzieniem ANO Konvencijas istenošanai (Saeima, 2013a).

Subsidētās darbavietas ir viens no instrumentiem, lai risinātu bezdarba problēmu. Sadarbībā ar Eiropas Sociālo fondu šobrīd aktuāls ir projekts "Subsidētās darbavietas bezdarbniekiem" (īstenošanas periods no 02.02.2015. līdz 31.12.2022.) (Nodarbinātỉbas valsts aǵentūra, 2017), kas paredz veicināt 4554 nelabvēlīgākā situācijā esošo bezdarbnieku, tostarp ilgstošo bezdarbnieku, iekḷaušanos sabiedrībā un iekārtošanos pastāvīgā darbā; kā pirmā mērķgrupa te minētas personas ar invaliditāti. 2017. gada otrajā pusē pieejamie apkopotie līdzšinējie projekta rezultāti (uz 2017. gada 30. septembri) rāda, ka projekta ietvaros izveidotas 530 subsidētās darbavietas bezdarbniekiem ar invaliditāti. ANO Konvencijas īstenošanas pamatnostādṇu (Saeima, 2013a) mērkị 2017. gadā bija subsidētajās darbavietās nodarbināt 600 cilvēku ar invaliditāti.

2017. gadā stājās spēkā MK noteikumi Nr. 94 "Kārtība, kādā persona saṇem valsts finansētus profesionālās rehabilitācijas pakalpojumus un profesionālās piemērotības noteikšanas pakalpojumu" (MK, 2017), kas noteic, kā saskañā ar Sociālo pakalpojumu un sociālās palīdzības likumu var saṇemt valsts finansētus profesionālās rehabilitācijas 
pakalpojumus un profesionālās piemērotības noteikšanas pakalpojumus personām darbspējas vecumā, ja tām ir noteikta vai prognozējama invaliditāte.

Darba likumā (Saeima, 2001) ir noteikta pozitīvā diskriminācija cilvēkiem ar invaliditāti; 109. panta 2. daḷa nosaka: "Darba devējam aizliegts uzteikt darba līgumu ar darbinieku, ja viņš atzìts par personu ar invaliditāti, izṇemot gadỉjumus, kas noteikti šā likuma 47. panta pirmajā daḷā un 101. panta pirmās daḷas 1., 2., 3., 4., 5., 6., 7. un 10. punktā."

Attiecīgi šãdi nosacījumi nevar būt iemesls darba attiecỉbu pārtraukšanai ar cilvēku ar invaliditāti:

- ir atjaunots darbā darbinieks, kurš agrāk veica attiecīgo darbu;

- tiek samazināts darbinieku skaits;

- darbinieks pārejošas darbnespējas dēl neveic darbu vairāk nekā sešus mēnešus, ja darbnespēja ir nepārtraukta, vai vienu gadu triju gadu periodā, ja darbnespēja atkārtojas ar pārtraukumiem, šajā laikā neieskaitot grūtniecības un dzemdỉbu atvaļinājumu, kā arī darbnespējas laiku, ja darbnespējas iemesls ir nelaimes gadījums darbā, kura cēlonis saistìts ar darba vides faktoru iedarbibu, vai arodslimỉba.

Likuma labvēlīgie nosacījumi personām ar invaliditāti veidoti, lai stiprinātu šo personu pozīcijas darba tirgū, tomēr realitātē šie noteikumi rada nevēlēšanos pieṇemt darbā cilvēku ar invaliditāti, domājot par iespējamiem sarežğijumiem, ja būs nepieciešams darbavietu uzteikt.

2017. gadā ir apstiprinātas izmaiņas Darba likumā. Sākotnēji valsts sekretāru sanāksmē februārī izsludinātie grozījumi paredzēja Darba likuma 109. panta izmaiņas, izslēdzot šā panta otro dalıu, kas paredz aizliegumu uzteikt darba līgumu darbiniekam ar invaliditāti. 2017. gada jūlijā Saeimā pieņemtie un izsludinātie Darba likuma grozījumi (Saeima, 2017b), kas stājās spēkā augustā, šo pantu tomēr nemaina.

DI plāna realizācija paredz, ka "katram projekta mērḳa grupas klientam atbilstoši viņa veselības stāvoklim, vēlmēm un individuālajiem mērḳiem ir noteiktas vajadzības sociālo pakalpojumu sniegšanai (sociālo pakalpojumu klāsts, vieta, biežums, apjoms) un vispārējo pakalpojumu pieejamībai (veselïbas aprūpe, izglìtība, transports, nodarbinātîba, mājoklis u. c.)" (Labklājības ministrija, 2015b, 23), kā arī 
paredz šo pakalpojumu attīstības plānošanu. DI plāna realizācijā runa ir ne tikai par nodarbinātību, bet arī par darbnīcām un dienas centriem.

Vēl viens darba devējam neizdevīgs nosacījums attiecībā uz personām ar invaliditāti ietverts likuma "Par maternitātes un slimības apdrošināšanu” (1995b) 36. pantā, kas nosaka darba devēja pienākumus izmaksāt no saviem līdzekḷiem slimības naudu par pirmajām 10 darbnespējas dienām. Invaliditāte var būt saistīta ar biežāku nepieciešamību izmantot darbnespējas dienas. Tādējādi darba devējam tiek uzlikts papildu slogs.

Gan Darba likumā, gan likumā "Par maternitātes un slimības apdrošināšanu" noteiktie nosacijumi faktiski negatīvi ietekmē darba devēja vēlmi uzsākt darba attiecības ar cilvēku ar invaliditāti. Šo problēmu Saeimas diskusijā "Saeima cilvēkiem ar invaliditāti" (Saeima, 2016) 2016. gada decembrī īpaši izcēla Latvijas Darba devēju konfederācijas pārstāvis.

Diskusijā "Saeima cilvēkiem ar invaliditāti" uzmanība tika vērsta uz atbalsta instrumentiem ekonomiskai neatkarībai un Sociālās uzṇēmējdarbības likumprojekta virzībai, kas ir nozīmīgs nodarbinātìbas veicināšanai un līdz ar to ekonomiskās situācijas uzlabošanai cilvēkiem ar invaliditāti.

2017. gada rudenī ir pieṇemts Sociālā uzṇēmuma likums (Saeima, 2017a) saskaṇā ar 2014. gadā izstrādāto koncepciju "Par sociālās uzṇēmējdarbības ieviešanas iespējām Latvijā" (Labklājības ministrija, 2014). Līdz Sociālā uzṇēmuma likuma pieņemšanai organizācijas ar sociāla uzṇēmuma pazìmēm - komersanti, biedrības vai nodibinājumi - darbojās citās uzṇēmējdarbības formās.

\subsection{Darbnīcas}

Problēmsituācija, kas saistīta ar darbnīcām, konstatēta astoṇās intervijās - četrās intervijās ar institūciju darbiniekiem, divās intervijās ar sociālā dienesta darbiniekiem un divās intervijās ar personām ar invaliditāti.

Galvenās situācijas, problēmas un izaicinājumi, kas atklāti empīriskajā izpētē:

- nepieciešamība pēc iespējas saturiski piepildīt dienu ar jēgpilnu nodarbi, apgūt prasmes; 
- augstas darbarīku, aprīkojuma, telpu izmaksas privātas darbnīcas uzturēšanai;

- prasmīga darbnīcas vadītāja palīdzība;

- apmaksātas nodarbinātības alternatīva;

- nodarbe cilvēkiem ar garīga rakstura traucējumiem.

Vajadzības:

- vajadzība pēc aprīkotas darbnīcas;

- vajadzība attīstīt sociālo uzñēmējdarbību.

Darbnīcas ir viena no iekḷaujošās nodarbinātības iespējām. Par šo nodarbinātības veidu, saucot to par darbnīcu, runā sociālo dienestu un institūciju pārstāvji. Šādas darbnīcas šobrīd novados nav pieejamas. "Vajadzība ir gan pēc nodarbinātības, gan pēc kaut kāda darba, nodarbošanās, kas varētu nebūt algots darbs ierastajā izpratnē, bet nodarbošanās. Trūkst sociālās uzṇēmējdarbības," saka sociālā dienesta pārstāve.

Personām ar invaliditāti pieejama darbnīca būtu iespēja nodarboties ar jau apgūtām lietām vai arī mācīties ko jaunu; darbnīcas princips var noderēt arī, lai apgūtu tādu it kā pašsaprotamu prasmi kā ēst gatavošana. Institūcijas pārstāvis saka: "Mūsu ergoterapijā viens no virzieniem ir virtuve, ka tur varētu mācìt kaut ko gatavot ēst. Bet tam vietu vajag." Cilvēki, kas uzauguši institūcijā, var arī neprast gatavot ēst. Šo prasmi apgūt būtu noderīgi, savukārt pratēji to var attīstìt.

Mācībās un attīstībā būtiska ir atsaucīga un prasmīga darbnīcas vadītāja klātbūtne. Arodu jau apguvušajiem, piemēram, ar galdnieka vai šuvēja iemaņām, tas risinātu darbnīcas izmaksu problēmu, jo uzturēt savu darbnīcu ir dārgi - darbarīki, aprīkojums, telpu izmaksas. Nozīmīga ir arī iespēja saturiski piepildìt dienu ar jēgpilnu nodarbi.

Sociālo pakalpojumu un sociālās palīdzības likums (Saeima, 2002a) specializētās darbnīcas definē kā sociālās rehabilitācijas pakalpojumu, kas nodrošina tādas aktivitātes, kuras attīsta prasmes, un speciālistu atbalstu personām ar funkcionāliem traucējumiem.

SP pamatnostādnēs (Saeima, 2013d) ir minēta specializētu darbnīcu izveide personām ar funkcionāliem traucējumiem. Specifiskais politikas mērḳis: sekmēt personu ar funkcionālajiem traucējumiem iekḷaušanos darba tirgū. Darba devēja uzdevums ir veicināt specializēto darbnīcu veidošanu personām ar funkcionāliem traucējumiem (Saeima, 2013d, 32. punkts). Darbnīcu funkcija dokumentā tiek saistīta arī ar sociālo uznēèmèjdarbību. 
DI plāna (Labklājības ministrija, 2015b) realizācija paredz specializētu darbnīcu izveidi kā vienu no pakalpojumu veidiem, kas veicinātu nodarbinātību personām ar garīga rakstura traucējumiem.

\subsection{Brīvais laiks un dienas aprūpes centri}

Problēmsituācija, kas saistīta ar brīvā laika pavadī̌anas iespējām un dienas centriem, konstatēta astoṇās intervijās - četrās intervijās ar institūciju darbiniekiem, divās intervijās ar sociālā dienesta darbiniekiem un divās intervijās ar personām ar invaliditāti. Jautājums par dienas centriem un brīvo laiku skatīts kā problēmsituācija tajās pašās intervijās, kur aktualizēts darbnīcu jautājums.

Galvenās situācijas, problēmas un izaicinājumi, kas atklāti empīriskajā izpētē:

- finansiālais aspekts: izmaksas par biḷetēm uz pasākumiem, papildu izmaksas par biḷti asistentam, ja tāds nepieciešams;

- atbilstošs transports cilvēkiem, kas izmanto ratiṇkrēslu, lai varētu doties ekskursijā ar autobusu;

- publisku WC pieejamība cilvēkiem, kas izmanto ratiņkrēslu (arī motorizētajiem modeḷiem); it īpaši ārā, piemēram, parkos;

- atbilstoša publisko èku un ceḷu infrastruktūra, kas cilvēkiem ratiņkrēslā nodrošina pieejamību;

- nespēja pietiekami bieži tikt pastaigās ārpus mājas;

- sociālie kontakti un aktivitātes, pulciņi; vieta, kur satikties.

Vajadzības:

- vajadzība pēc grupu nodarbībām, aktivitātēm (lai motivētu, sniegtu emocionālu atbalstu, iepazìtos, gūtu iespēju socializēties, veidot attiecības, piedalīties fiziskās aktivitātēs);

- vajadzība atrast/piesaistīt spējīgus grupu nodarbību vadītājus;

- cilvēkiem, kas lieto ratiņkrēslu, vajadzība pēc piemērotas infrastruktūras un pieejamas vides;

- vajadzība pēc lielāka stundu skaita tiem asistenta pakalpojumiem, kas nepieciešami brīvā laika aktivitātēm (šobrīd pašvaldỉba var nodrošināt līdz pat 40 stundu ilgu asistenta pakalpojumu nedēẹā, tomēr tikai divas stundas var tikt izmantotas brīvā laika aktivitātēm (MK 2012d); cilvēkam, kurš nespēj pats apgeērbties (krampji, apgeērbšanās āra pastaigai var prasît pat stundu asistenta laika) un izmanto ratinkkrēslu, tas nozìmē 
iespēju tikt izvestam ārpus mājas pat retāk nekā vienu reizi nedēlā;

- vajadzība pēc dienas aprūpes centriem (lauku reǵionā, uz ietas).

Brīvā laika pavadīšana personām ar invaliditāti ir svarīga, it sevišḳi tāpēc, ka nodarbinātība (kā algots darbs) ne vienmēr ir pieejama vai iespējama. Lauku reǵionos, organizējot interešu grupas, nodarbības, jāṇem vērā, ka attālumi ir lielāki nekā pilsētās, cilvēku ir mazāk, iedzīvotāju blīvums ir zemāks, transports var būt problēma, tāpēc iesaiste dažādos pasākumos ir mazāka; paralēli jārisina transporta jautājums.

Atsevišķa uzmanība, skatot brīvā laika jautājumu, jāvelta cilvēkiem, kam saskaṇā ar likumu pienākas (tātad ir nepieciešams) asistenta pakalpojums. Asistenta pakalpojums brìvajam laikam pieejams vien ne vairāk kā divas stundas nedēḷā (MK, 2012d, 1. pielikums: "Iesaistǐšanās sociālās iekḷaušanas pasākumos (iepirkšanās, teātru, koncertu, sporta spẹ̄u, citu pasākumu un sabiedrisku vietu apmeklējums, kas saistìts ar brīvā laika pavadī̌sanu)"). Tas ir lıti maz. Persona ar invaliditāti saka: "Asistenta pakalpojumus vajag vairāk. Vajag vismaz divdesmit stundas nedēḷā, asistents (divās stundās) var nevarēt pat izvest ārā (vienreiz nedēlāa)."

Katrs gadījums ir individuāls, un ne visi (funkcionālo traucējumu un veselības dẹl) var iesaistīties tādās aktivitātēs kā algots darbs, izglìtība, sociālie pasākumi, kas minēti MK noteikumos (MK, 2012d), tomēr katram cilvēkam būtu nepieciešams nodrošināt iespēju katru dienu kaut uz stundu iziet ārā, svaigā gaisā. Funkcionālie traucējumi un citas veselības problēmas var ḷoti palēnināt apgēerbšanos, iesēšanos ratiņkrēslā un citas darbības, kas nepieciešamas, lai nokḷūtu ārpus mājas.

Intervijās ar personām ar invaliditāti tika apspriests arī jautājums par to, ka asistenta klātbūtne var būt nepieciešama gan transportā, gan koncerta apmeklējumā, kur arī asistentam vajadzīga biḷete; tādējādi iespēja cilvēkam, kas izmanto asistenta pakalpojumu, apmeklēt pasākumu ievērojami sadārdzinās.

Cilvēkiem, kas izmanto ratiṇkrēslu, joprojām lielas neērtības sagādā vides nepieejamība - gan publisko èku un ceḷu infrastruktūra, gan arī publisku tualešu pieejamība cilvēkiem ar ratiṇkrēslu (arī motorizētajiem modeḷiem, kas ir platāki), it īpaši ārā, piemēram, parkos.

Intervijā izskanēja arī konkrēta vēlme ierīkot makšķerēšanas vietu, kas būtu èrta cilvēkiem, kuri izmanto ratiṇkrēslu. 
Dienas centri ir vēl viena sociālās rehabilitācijas un saturīga laika pavadīšanas iespēja. SP pamatnostādṇu (Saeima, 2013d) rīcības virziens "Sabiedrībā balstīti, pēctecīgi un klienta vajadzībām atbilstoši sociālie pakalpojumi” paredz specifisko politikas mērḳi: veicināt sociālās aprūpes un sociālās rehabilitācijas pakalpojumu attīstību personu dzīvesvietā. Viens no uzdevumiem, piemēram, ir nodrošināt personām pieskatǐšanu dienas laikā un aktivitātes, kas veicina nodarbinātību, tāpēc ik gadu tiek izveidots viens dienas aprūpes centrs vai radītas jaunas vietas dienas aprūpes centros. Šis pasākums tiek realizēts sadarbībā ar Eiropas sociālo fondu. Arī DI plāna (Saeima, 2013a) realizācija paredz dienas aprūpes centru attīstību.

Asistenta pakalpojums ir būtisks smagu funkcionālo traucējumu gadỉjumā. Asistenta pakalpojuma saṇemšanu saskaṇā ar Sociālo pakalpojumu un sociālās palīdzības likumu (Saeima, 2002a) un Invaliditātes likumu (Saeima, 2010a) nosaka:

- Ministru kabineta noteikumi Nr. 698 "Par pabalstu par asistenta izmantošanu personām ar I grupas redzes invaliditāti" (pabalsta apmērs ir 17,07 eiro nedẹl̦ā (par 10 stundām nedēḷā)) (MK, 2016);

- Ministru kabineta noteikumi Nr. 942 "Kārtība, kādā piešķir un finansē asistenta pakalpojumu pašvaldībā" (brīvā laika pavadīšanai - līdz divām stundām nedēḷā) (MK, 2012d);

- Ministru kabineta noteikumi Nr. 695 "Kārtība, kādā pieškir un finansē asistenta pakalpojumu izglîtíbas iestādē” (MK, 2012c).

Latvijas Republikas Valsts kontroles revizijas ziņojums "Vai personām ar invaliditāti paredzētais asistenta pakalpojums nodrošina tā izveidošanas mērḳu sasniegšanu?” (Valsts kontrole, 2015) norāda uz virkni trūkumu un mērķu nesasniegšanu. Revīzijas ziņojumā un sabiedrības diskusijā gan neparādās būtisks trūkums asistenta pakalpojuma pieejamībā - divas stundas nedēḷā brīvā laika pavadīšanai nevar pietiekami nodrošināt iespēju tikt ārpus telpām cilvēkam ar invaliditāti, kam šis pakalpojums nepieciešams, lai to izdarītu. Izpratni par problēmu jau 2015. gada februārī ir paudis toreizējais labklājības ministrs Uldis Augulis: "Savukārt jautājums par asistenta pakalpojumu brīvā laika pavadī̌anai līdz 10 stundām nedẹl̦ā cilvēkiem ar smagu invaliditāti ir nonācis strupceḷā, tāpēc nekavējoties jāatrisina." (Labklājības ministrija, 2015a) 
2015. gadā runa bija arī par normatīvo noteikumu sakārtošanu saistībā ar asistenta pakalpojuma saņemšanu un sniegšanu. Jautājums par brīvā laika pavadī̌anai pieejamajām asistenta stundām netika atrisināts.

2017. gadā saistībā ar Valsts kontroles revīzijas ziņojumu un ANO konvencijas īstenošanas pamatnostādṇu realizāciju jautājums ir aktualizēts, tādēḷ svarīgi, lai darba kārtībā paradītos arī jautājums par to, ka brīvā laika pavadī̌anai ir nepieciešams lielāks asistenta stundu skaits, par kurām maksā pašvaldība vai valsts.

\subsection{Sabiedrības attieksme}

Problēmsituācijas, kas saistītas ar sabiedrības attieksmi, konstatētas sešās intervijās - trīs intervijās ar institūciju pārstāvjiem, vienā intervijā ar sociālā dienesta pārstāvjiem un divās intervijās ar personām ar invaliditāti.

Galvenās situācijas, problēmas un izaicinājumi, kas atklāti empīriskajā izpētē:

- cilvēki blenž, atskatās uz personām ar redzamu invaliditāti, ir apsmiešanas gadijumi;

- naudas izkrāpšanas gadījumi; personu ar invaliditāti piemānīšana (piemēram, ja viņas nesaprot naudas vērtību); personas ar invaliditāti pases izmantošana, lai paṇemtu kredītu; pašas personas ar invaliditāti pierunāšana paṇemt kredītu, lai naudu pēcāk izkrāptu;

- DI kontekstā aktuāli jautājumi: kā pasargāt no necieņas, apsmiešanas publiskajā telpā; kā pasargāt no nodarījumiem, kam nav krimināla sastāva; kā mazināt risku kḷùt par kriminālpārkāpuma upuri.

Vajadzības:

- vajadzība pēc cieņas;

- vajadzíba pēc drošǐbas;

- vajadzība pēc izglītotas, iejūtīgas sabiedrības (vajadzība sabiedrỉbu izglitot).

Sabiedrības attieksme un rīcība ir nozìmīgs jautājums, kas tieši attiecas uz aktuālo iekḷaujošo politiku. Intervijās cilvēki, kas izmanto ratiṇkrēslu, minēja, ka ikdienā saskaras ar līdzcilvēku nepatīkamo 
attieksmi; viņi min, ka pietrūkst sabiedrības cilvēcības. Cilvēki uz ielas lūr, atskatās, un tas nav patîkami.

Intervijās minēts, ka sabiedrībā trūkst izpratnes par situācijām, kādā persona ar invaliditāti var nonākt, kā arī trūkst līdzcietības. Grupas intervijā ar personām ar invaliditāti risinājās šāda saruna, kas spilgti ilustrē situāciju: A (persona ar invaliditāti): "Ja es guḷu grāvī, es varu salīt, simt procenti - visi aizies garām. Un dažs labs vēl pateiks - re, ku' tā vecene guḷ tai grāvī." S (persona ar invaliditāti): "Un vēl pateiks, re, ku' tā laikam ir piesūkusies. Es pati personīgi esmu izjutusi šito uz savu ādu." MG (personas ar invaliditāti tuvinieks): "Kamēr tu pats personīgi nesaskaries ar to, tu nesāc citādāk domāt." S (persona ar invaliditāti): "Es redzu, ka cilvēkam slikti, es pieiešu klāt - vai piedzēries vai nē - tad es zināšu. Bet mūsu attieksme mūsu valstī točno ir šitāda (ka nepieiet klāt), jo man šitā smagā slimība, ka es atslēdzos un pat esmu aizgājusi komā, grāvī gulēdama, - visi aizgāja garām. Bet to, ka cilvēks savu mūžu nav pat pan̄ēmis mutē alkoholu, to neviens nezina.”

Intervijās ar institūciju un sociālo dienestu pārstāvjiem tika vairākkārt uzsvērts, ka cilvēki ar garīgās attīstības funkcionāliem traucējumiem ir paḳ̣auti riskam, ka tos l̦aunprātīgi izmantos līdzcilvēki. Stāsta sociālā dienesta pārstāvis: "Liela problēma ir līdzcilvēki. Ir, kas izkrāpj no šiem cilvēkiem to pašu pensiju. Ir, kam ir vairāk, ir invaliditātes pensija un apgādnieka zaudējuma pensija. Un izkrāpj."

Gan institūciju, gan sociālā dienesta pārstāvji stāsta par gadījumiem, kad no cilvēka ar garīgās attīstības funkcionāliem traucējumiem kāds līdzcilvēks paṇem pasi, ko izmanto, lai paņemtu kredìtu vai aizdevumu. Ne visi cilvēki ar garīgās attīstības traucējumiem labi izprot naudas vērtỉbu. "Cenšos skaidrot viņam (naudas vērtību), bet tad viņš iziet uz ielas, kur ir tie, kas redz, ka viņš nesaprot naudu. Piemēram, viņam ir banknotes - 20, 10 un 5 eiro. Un viņš domā, ka viṇam ir 30 nevis 35 eiro," stāsta institūcijas pārstāvis.

Sabiedrības izpratne ir viens no četriem prioritārajiem virzieniem ANO Konvencijas īstenošanai (Saeima, 2013a). ANO Konvencija attiecas uz visu personu ar invaliditāti tiesībām un pamatbrīvībām. Šis rīcības virziens kḷūst divtik svarīgs DI plāna realizācijā.

LM 2017. gada augustā ir publicējusi dokumentu "Indikatoru saraksts ANO Konvencijas par personu ar invaliditāti tiesībām monitoringam" (Labklājības ministrija, 2017a), kur, izmantojot tiesībsarga pētijuma rezultātus, pirmais indikators ir sociālā distance kopienā un 
kā rādītājs skatìts to iedzìvotāju īpatsvars, kuri izjustu diskomfortu, ja vinu apkaimē dzīvotu persona ar invaliditāti. Korekti pārrēḳinot (skat. 1. pielikumu), 9\% Latvijas iedzīvotāju izjustu diskomfortu, ja apkaimē vai kaimiņos dzīvotu cilvēki ar kustību, redzes vai dzirdes traucējumiem, 15\% - ja dzīvotu cilvēki ar ilgstošiem veselības traucējumiem, $34 \%$ - ja dzīvotu cilvēki ar intelektuālās attīstỉbas traucējumiem, bet 46\% - ja dzīvotu cilvēki ar psihiskām saslimšanām.

ANO Konvencijas īstenošanas pamatnostādnēs vērojama nesaskaņotība starp politikas rezultātu "Paaugstinājies sabiedrības informètības un izpratnes līmenis par personu ar invaliditāti tiesību jautājumiem" un uz šo rezultātu attiecināmo rezultatīvo rādītāju "Tiesībsarga saṇemto iesniegumu skaits par iespējamo diskrimināciju” ANO Konvencijas īstenošanas pamatnostādnēs (Saeima, 2013a, 83). Vēlamais rezultatīvais rādītājs ir iesniegumu skaita pieaugums. Taču, ja iesniegumu skaits, kurus saṇēmis tiesībsargs, ir pieaudzis, tas nebūt neliecina par augstāku kopējo sabiedrības informètības un izpratnes limeni.

DI realizācijas plāna (Labklājības ministrija, 2015b) viens no diviem darbības virzieniem ir "Sabiedrības un speciālistu attieksmes maiņa", kur viens no rezultātiem ir "veikts sabiedrības un speciālistu attieksmes maiņas monitorings”. Saskaņā ar pasākumu plānu 2015. gadā ir notikusi "Ex-ante novērtējuma veikšana par sabiedrïbas un speciālistu attieksmi, balstoties uz ekspertu piedāvāto metodiku”, par ko atbildīgie ir LM iepirktie sabiedrisko attiecibu eksperti (Labklājỉbas ministrija, 2015b, 19), un 2022. gadā tiks "veikts ex-post novērtējums par sabiedrỉbas un speciālistu attieksmes maiņu, balstoties uz ekspertu piedāvāto metodiku", par ko atbildīgi atkal ir LM iepirktie sabiedrisko attiecibu eksperti (Labklājibas ministrija, 2015b, 22). Te bažas rada divi aspekti. Pirmkārt, monitoringā ir paredzēti tikai divi piegājieni, - uzsākot DI plāna realizēšanu un pēc DI plāna realizācijas; to nevar uzskatīt par pilnvērtīgu monitoringu, jo monitorings paredz regulāru situācijas apzināšanu procesa gaitā. Otrkārt, ir būtiska atškirīiba starp sabiedrisko attiecību speciālistu darbu un sabiedrības attieksmes monitoringu. Sabiedrības attieksmes mērïjums nevar balstìties uz mērḳtiecīgi virzītām publikācijām medijos, ko varētu solīt iepirkti sabiedrisko attiecību eksperti.

Sabiedrības attieksmi un rīcību raksturo, piemēram, noziedzīgu nodarījumu skaits pret kādu noteiktu sabiedrības grupu. Empīriskajā 
izpētē atklājās personu ar invaliditāti, it seviški ar garīgās attīstības funkcionāliem traucējumiem, predispozīcija kḷūt par citu sabiedrības locekḷu l̦aunprātības vai krāpniecības upuriem. DI plāna realizācijā būtu nepieciešams ieviest papildu monitoringu tieši noziedzīgu nodarījumu uzskaitei attiecībā uz DI plāna mērkgrupu. Arī 2017. gadā publicētajā "Pètījumā par starptautisko praksi personu ar invaliditāti atbalsta sistēmu jomā" (Labklājības ministrija, 2017b) uzsvērts, ka būtu nepieciešams ieviest "invaliditātes griezumu” Iekšlietu ministrijas Noziedzīgo nodarỉjumu reǵistra datos un šos datus ņemt vērā, vērtējot DI plāna realizācijas gaitu un sekas. Šobrīd nevienā politikas plānošanas vai realizēšanas dokumentā rezultatīvajos rādìtājos šāds datu griezums neparādās.

\subsection{Bērnu aprūpe}

Problēmsituācija, kas saistìta ar bērnu aprūpi, konstatēta trīs intervijās - divās intervijās ar institūcijas darbiniekiem un vienā intervijā ar sociālā dienesta darbiniekiem.

Galvenās situācijas, problēmas un izaicinājumi, kas atklāti empīriskajā izpētē:

- tādu bērnu (it sevišḳi jaundzimušo) aprūpe, kas dzimuši personām ar garīgās attīstības funkcionāliem traucējumiem.

Vajadzības:

- vajadzība pēc asistenta pakalpojuma;

- vajadzība pēc kontracepcijas.

Par problēmsituācijām, kas var rasties saistībā ar bērna piedzimšanu personai ar garīgās attīstības funkcionāliem traucējumiem, intervijās runā institūciju pārstāvji un sociālo pakalpojumu sniedzēji. Taisnības labad jāatzīmē, ka intervijās minēti arī pozitīvas pieredzes gadỉjumi, tomēr tie ir izṇēmumi. Lai ilustrētu problēmas apmēru un nozīmi, pievienoju piecus sarunas fragmentus no četrām dažādām intervijām, visās runa ir par personām ar invaliditāti - ar intelektuālas vai garīgās attīstības traucējumiem.

Institūcijas pārstāvis: "Šiem cilvēkiem lielu dienas daļu aizṇem arī tādas lietas, par ko nerunā. Viṇi komunicē savā veidā, viṇiem ir savas attiecibas, savas problēmas. Citreiz kaut ko gimenei līdzīgu veido. It kā jau tas ir labi. Bet to kaut kā ignorē. It sevišķi, ja tie ir jauni cilvēki, tas jau ir dabiski, ka viṇiem interesē pretējais dzimums, ka 
vinịi nodibina attiecības. Bet .. tā ir papildus problēma tam visam. Arī par to būs jādomā. Gadās, ka bērni piedzimst. Vajag vismaz apmācìt, izglītot, cik nu var. Tā arì būs viena problēma, ja jaunus cilvēkus palaidīs (deinstitucionalizācijas rezultātā ārpus institūcijām - autores piezīme)."

Institūcijas pārstāvis: "Vēl ir ḷoti grūti meitenēm ar gimenes veidošanas jautājumu. Tas ir smags jautājums. Mēs visi esam humāni cilvēki. Un viṇas nevar pierunāt... Viṇas gaida bērninuu kā lelli, un "es tagad būšu îsta sieviete". Bet meitenes nesaprot, ka tas nav tikai paspēlēties, bet jācel̦as naktī un tamlīdzīgi. Pašai nav izpratnes par to, kā pašai gèrbties - novembrī iet ar vasaras kurpēm ārā. Tāpat arī bērnam - uzvelk skaistu kleitinu, bet neiedomājas, ka ārā ir ziema."

Institūcijas pārstāvis: "Ir gadījumi, kad veido gimenes, dzimst bērni. Ir divi gadijjumi, kad bijušajiem klientiem ir dzimuši bērni, abos gadījumos bērni atrodas Liepājas aprūpes iestādēs. Pat ja rīcībspēja ir noṇemta, to nevar ierobežot (reproduktīvās funkcijas - autores piezime)."

Sociālā dienesta darbinieks: "Bērnu dzimšana. Ir, kas tiek galā, un ir, kas netiek. Faktiski ir vajadzīga 24 stundu asistence."

Sociālā dienesta darbinieks: "Ir gadījums, kad pirmais bērns jau ir aprūpes iestādē, un tūlīt būs otrs bērns... Ģimenes ar tādām problēmām labi prot dot sociāli vēlamas atbildes. Ir jābūt speciālistam, bet nav, kas strādātu tieši ar psihiski slimiem, garīgi atpalikušiem cilvēkiem."

Sociālā dienesta un institūciju pārstāvji ir pārliecināti, ka šis jautājums prasa pastiprinātu uzmanību un saistībā ar DI plāna realizāciju kḷūs arvien aktuālāks.

Būtiski ir veidot izpratni par reproduktīvo veselību un kontracepciju, kā arī svarīga ir kontracepcijas pieejamība, jo tās iegāde prasa finansiālu ieguldījumu.

Tiesības radīt bērnus ir viena no cilvēktiesībām, kas ir arī ANO Konvencijas daļa (ANO, 2006). Tomēr te būtiski apzināt, izstrādāt un ieviest atbalstošus pasākumus, kas nepieciešami, lai tiktu ievērotas radīto bērnu tiesības, garantēta droša un attīstỉbu sekmējoša vide. Jāsaprot, ka var būt nepieciešams nodrošināt apjomīgu palīdzību bērna aprūpē. Saistībā ar DI plāna realizāciju jautājums kḷūs aktuālāks.

Veselības ministrijas SV pamatnostādnēs (Saeima, 2013c) mātes, tēva un bērna veselība ir viens no galvenajiem rīcības virzieniem; te 
uzsvērts jautājums par to, ka trūkst zināšanu gan par reproduktīvo veselību, gan bērna aprūpi un drošìbu, kā arī ar to saistītā riska uzvedību. Šo Veselības ministrijas pārraudzīto SV pamatnostādṇu rīcības virzienu ir svarīgi sasaistìt ar Labklājības ministrijas realizējamo DI plānu (Labklājības ministrija, 2015b), lai savlaicīgi plānotu un nodrošinātu nepieciešamos pasākumus.

\subsection{Sociālie kontakti, ğimenes veidošana}

Problēmsituācija, kas saistīta ar spēju darboties, konstatēta sešās intervijās - četrās intervijās ar personām ar invaliditāti, vienā intervijā ar institūcijas pārstāvi un vienā intervijā ar sociālā dienesta darbiniekiem.

Galvenās situācijas, problēmas un izaicinājumi, kas atklāti empīriskajā izpētē:

- vientulības problēma;

- grūtības atrast līdzcilvēku romantiskām attiecibām, dzīvesbiedru.

Vajadzības:

- vajadzība pèc pozitīvas sociālas mijiedarbes, komunikācijas, klātbūtnes sajūtas.

Sociālo kontaktu trūkums ir viena no problēmām, ar ko personas ar invaliditāti saskaras. Sieviete, kas izmanto ratiņkrēslu, intervijā stāsta, ka ziemā bieži vien viṇa netiek ārā no mājas, nav ar ko parunāt. Gados jaunākās personas ar invaliditāti norāda, ka gribētu iepazìties, dibināt ǵimeni, bet ir problēma iepazìties, satikt cilvēku, ar ko varētu būt kopā.

Arī sociālo dienestu darbinieki iezīmē vientulību kā problēmu, kas skar personas ar invaliditāti, it seviški lauku regiionos. "Trūkst sociālie mentori. Kāds, ar ko parunāt. Cilvēki jūtas vientuḷi, grib, lai brauc un runā, bet nav jau tik daudz to darbinieku, lai brauktu parunāt. Laukos ir daudz vientuḷo cilvēku," sociālo pakalpojumu sniedzējs intervijā uzsver problēmas aktualitāti tieši lauku reǵionos.

Vajadzība pēc sociālajiem kontaktiem un to realizēšanas iespējas atkal ir cieši saistītas ar transportu, nodarbinātību, darbnīcām, brīvo laiku, sabiedrības attieksmi. Indikatoru sarakstā ANO Konvencijas par personu ar invaliditāti tiesībām uz monitoringu (Labklājības ministrija, 2017a) 23. panta "Cieņa pret dzivesvietu un gimeni” indikatori 
ietver asistenta pakalpojuma izmantošanas rādītāju, tomēr dati atspoguḷo tikai pakalpojumu saṇēmēju skaitu, nevis stundas, kas paredzētas ǵimenes aktivitāšu atbalstam. Jāatgādina, ka MK noteikumi Nr. 942 (2012d) par asistenta pakalpojumu nodrošināšanu šādām ārpus institūciju un organizāciju aktivitātēm paredz ne vairāk kā divas stundas nedēẹā.

Infrastruktūru sociālo kontaktu realizēšanai zināmā mērā attīstìtu DI plāna (Labklājības ministrija, 2015b) aktivitātes un finansiālie ieguldījumi. Tomēr būtiski, lai nepieciešamās aktivitātes un infrastruktūra būtu pieejamas arī tām personām ar invaliditāti, kas nav DI mērḳgrupā.

Sociālo kontaktu nodrošināšanai platformu var piedāvāt arī sabiedriskās organizācijas, nodibinājumi, sociālā uzṇēmējdarbỉba, tāpēc svarīga ir sakārtota likumdošana un šo organizāciju atvieglojuma/atbalsta pasākumi.

\subsection{Spēja darboties}

Problēmsituācija, kas saistīta ar spēju darboties, konstatēta piecās intervijās - trīs intervijās ar institūciju pārstāvjiem un abās intervijās ar sociālā dienesta darbiniekiem.

Galvenās situācijas, problēmas un izaicinājumi, kas atklāti empīriskajā izpētē:

- kā motivēt rīcībai, sākot ar pašaprūpi (mazgāšanās, tīras drēbes) un beidzot ar dalību piedāvātajās grupu nodarbībās un citās aktivitātēs;

- DI kontekstā - cilvēki, kas ilgstoši uzturējušies sociālās aprūpes institūcijās, ir pieraduši pie aprūpes, regulāra uzmundrinājuma un motivēšanas.

Vajadzības:

- vajadzība pēc motivēšanas un iedrošinājuma;

- vajadzība pēc nemitīgas pozitīvas atgriezeniskās saites (attiecìbā uz darbību).

Spēja darboties ir saistīta ar motivāciju. Šĩ nepieciešamība motivēt, atgādināt, iedrošināt atklājās intervijās ar institūciju pārstāvjiem un sociālo pakalpojumu sniedzējiem. Institūciju pārstāvji īpaši uzsvēra, ka cilvēki, kas dzīvojuši institūcijās, ir pieraduši pie aprūpes, viņi atradinās no pašaprūpes un paši vairs netiek galā ar ikdienas pienākumiem; 
to ir grūti no jauna iemācīties. Institūciju pārstāvji norāda, ka bieži vien ir jāmotivē mazgāties, uzvilkt tīras drēbes; cilvēki ir pieraduši, ka atgādina, uzslavē, pieskata. Cilvēki ar psihiskām saslimšanām bieži vien jāmotivē arī dzert medikamentus; medikamentu lietošana var būt izšḳiroša veselības stāvokḷa stabilitātei, paša un citu drošībai.

Tomēr arī ilgstošs bezdarbs un izkrišana no aprites var radīt grūti pārvaramus šḳēršlus: "Ir arī tā, ka cilvēks divus trīs gadus no darba aprites ir izgājis ārā, piecus pat. Viņam no rīta, vakarā noliktas zeḳes, bikses, maizìtes sasmērētas, noliktas, ceḷanauda atrasta, cimdiņi, viss salikts, un iziet noteiktā laikā uz autobusu - viņš vairs to nevar. Viņš ir ārā no tās aprites, viṇš tai ritmā vairs ierakstìties nevar," stāsta sociālā dienesta pārstāve.

Sociālo pakalpojumu sniedzēji norāda, ka gribētu, lai būtu vairāk iespēju sniegt šo motivējošo atbalstu, stimulēt; aizņemtība nel̦auj tam veltīt tik daudz laika, cik nepieciešams.

DI plāna realizācijas (Labklājỉbas ministrija, 2015b) pasākumi palīdz nodrošināt mācītu sociālo mentoru un atbalsta personu pakalpojumus. Šādi pakalpojumi varētu būt nepieciešami arī cilvēkiem ar invaliditāti, kas nav DI mērkgrupāa jo funkcionālo traucējumu apgrūtinājums var radīt papildu šķēršlus, arī emocionālus un psihologiskus, ikdienišķu darbību veikšanai.

\subsection{Atkarību pārvarēšana}

Problēmsituācija, kas saistīta ar atkarībām, konstatēta piecās intervijās - trīs intervijās ar institūciju pārstāvjiem un abās intervijās ar sociālā dienesta darbiniekiem.

Galvenās situācijas, problēmas un izaicinājumi, kas atklāti empīriskajā izpētē:

- alkohols, azartspēles, narkotikas;

- kafija un cigaretes - lielākās personisko izdevumu pozīcijas cilvēkiem, kas dzīvo aprūpes institūcijā.

Vajadzibas:

- vajadzība pēc motivācijas cīnīties ar atkarību;

- vajadzíba pēc palīdzíbas, lai uzveiktu atkarību.

Atkarības ir viena no problēmām, kas atklājās intervijās ar sociālo pakalpojumu sniedzējiem un institūciju pārstāvjiem: "Turklāt 
alkoholisms ir problēma. Ne visiem, protams. Bet tā ir smaga tēma. Problēma," uzsver sociālo pakalpojumu sniedzējs.

Intervijās runa ir par alkoholu, cigaretēm, arī azartspēlēm. Tiek minēti gadījumi, kad alkohols lietots kopā ar medikamentiem. Atkarības tiek uzsvērta kā problēma, kas rada virkni turpmāku sarežğijumu. Azartspēles kombinācijā ar viegli pieejamiem ātrajiem kredītiem situàciju pasliktina.

Institūciju klientu attiecībās īpašu vietu ir ieņēmušas kafija un cigaretes. Personas ar invaliditāti, kas dzīvo institūcijās, šìm precēm regulāri tērē savus nelielos finanšu līdzekḷus: "Kafija un cigaretes ir galvenās pozīcijas, kam (klienti) tērē savus līdzekḷus. Pensijas ir nelielas, no tā paliek desmit procenti personīgiem tēriņiem. Ja kafijai un cigaretēm naudas nav, tad izprasa citiem, lai uzcienā. Kafija un cigaretes ir svarīgas. Ikdienā daudz sarunas, darbības, kas ar to saistìtas," intervijā stāsta institūcijas pārstāvis. Kafija ierasti netiek skatīta kā atkarību izraisoša viela, ar kuras lietošanu jācīnās, tomēr, tā kā empīijā tā parādās tieši šādā kombinācijā - kafija un cigaretes, tad arī šeit šì kombinācija saglabāta.

Sociālā dienesta pārstāvis kā piemēru atkarību sekām min gadījumu, kad persona ar invaliditāti azartspēelēs zaudējusi praktiski visu mantoto īpašumu, kḷūstot par personu, kam nepieciešama sociāla palīdzība.

SV pamatnostādnēs (Saeima, 2013c), skatot neinfekcijas slimības un to riska faktorus, uzsvērta vajadzība turpināt darbu, lai sabiedrībā samazinātu atkarību izraisošo vielu lietošanu un atkarību procesus: "Turpināt ìstenot vienotu politiku dažāda veida atkarību izraisošo vielu (tabakas izstrādājumu, alkohola, narkotisko vielu (t. sk. jauno psihoaktīvo vielu)) lietošanas un atkarību procesu samazināšanai sabiedrībā, uzlabojot iedzivotāju zināšanas par šo vielu kaitīgo ietekmi uz veselību, ierobežojot reklāmu un pieejamību, izstrādājot normatīvo regulējumu jaunu tabakas un citu atkarības vielas saturošu izstrādājumu izplatī̌sanas regulēšanai."

Runa ir par dažādām atkarỉbu izraisošām vielām; azartspēles SV pamatnostādnēs netiek pieminētas vispār. Ārstniecības likums (Saeima, 1997a) azartspēḷu ārstēšanu skata lỉdztekus citām atkarībām.

Personas ar invaliditāti, līdzīgi kā citi cilvēki, mēdz ciest no dažādām atkarībām. Plašāku analīzi, vai cilvēki ar invaliditāti ir vairāk 
predisponēti atkarībām (Blum, 2001), šajā pētījumā neveicu. Tomēr jau skatītā vientulības problēma, finansiālās problēmas, dažādi bezcerību veicinoši faktori droši vien nestiprina rezistenci pret dažādām atkarībām.

Šajā publikācijā personu ar invaliditāti vajadzības grupētas tematiski, tām nav hierarhiskas kārtības. Saskaņā ar Maslova motivācijas teorijā piedāvāto vajadzību grupēšanu hierarhiski, to attiecīgi var darīt, veselību, dzìvesvietas kvalitāti, mājsaimniecỉbas un transporta jautājumu attiecinot uz (1) fiziolog̣isko un (2) drošỉbas vajadzību līmeni; sabiedrības attieksmi, piemēram, var attiecināt gan uz (2) drošību, gan (3) piederību, gan (4) cieņu. Būtiski uzsvērt, ka, skatot sabiedrības attieksmi, ir runa ne tikai par cieņu, bet arī par drošîbu, kas ir hierarhiski otrā zemākā vajadzību grupa, kura nosaka motivāciju. Nodarbinātība, darbnīcu iespējas un brīvais laiks intervijās drīzāk parādījās (1) fiziologisko vajadzību nodrošināšanas, (3) piederības, nevis (5) pašizpausmes kontekstā. Intervijās dominēja Maslova motivācijas teorijas pirmo trīs līmeņu vajadzības - (1) fizioloǵiskās, (2) drošības un (3) piederības vajadzības. Tas nenozīmē, ka nepastāv (4) cieņas un (5) pašizpausmes vajadzības. Intervijās iegūtie dati nesniedz materiālu kognitīvo vajadzību, estētisko vajadzību un transcendences analīzi. Saskaņā ar Maslova teoriju, lai dominējoši realizētos hierarhiski augstāku vajadzību apmierināšanai virzìts uzvedības modelis, indivīdam zināmā mērā (ne pilnīgi, bet apmierinoši) jānodrošina hierarhiski zemāk esošo vajadzību apmierināšana, kas, kā liecina empīiski dati, var būt problemātiska.

ANO Konvencija balstās uz indivīda cieņu un vērtības atzǐšanu (Saeima, 2006). Cieṇa ir fenomens, kas veidojas mijiedarbē. Tādējādi secinājums, ka individuālo uzvedības modeli noteicošā motivācija lielākoties tiek pamatota ar hierarhiski zemāku vajadzību realizēšanu, norāda uz iespējamiem sarežğỉjumiem ANO Konvencijas paradigmas realizēšanā.

Pètījumā izmantotas kvalitatīvās metodes, un tādējādi apzināts problēmu spektrs. Katra problēmsituācija nav attiecināma uz ikvienu personu ar invaliditāti. Lìdztekus ir iespējama situācija, kad persona ar invaliditāti realizē visu līmeṇu vajadzības un balsta uzvedỉbas modeli (4) cieņas un (5) pašizpausmes vajadzību grupā. Tomēr pētījuma rezultāti liek domāt, ka tas drīzāk varētu būt giimenes, tuvo cilvēku 
konteksts, kas to veicina, nevis politikas veidošanas un realizēšanas rezultāts.

Pētījums sniedz vispārēju ieskatu personu ar invaliditāti situācijā. Tālākai izpētei būtu nepieciešams pievērsties vajadzībām un šķēršlı̆iem, kas specifiski saistīti ar funkcionālo traucējumu veidu.

\section{Personu ar invaliditāti iesaistīšana un iesaistī̌sanās sociālo pakalpojumu sniegšanā}

Personu ar invaliditāti iesaistī̌sana un iesaistǐšanās sociālo pakalpojumu sniegšanā ir iespēja veidot labākus un saṇēmējam atbilstošākus sociālos pakalpojumus. Tā nav pakalpojuma saṇēmèja vajadzību tūlītēja apmierināšana, bet ir līdzdalỉbas veicināšana, kur nozīmīgs ir ne tikai rezultāts, bet arī pats process. Iesaistī̌sana un iesaistīšanās ir nozīmīgas komponentes sociālo pakalpojumu saṇēmēju vajadzību apmierināšanai un problēmsituāciju risināšanai. Ieguvums ir gan vajadzību un iespējamo risinājumu apzināšana, gan arī vajadzību - sociālie kontakti un mijiedarbe, savstarpējais atbalsts un atzǐšana - risināšana. Empīriski pētot personu ar invaliditāti vajadzỉbas, atklājās dažādas iesaistīšanas un iesaistī̌sanās prakses.

Institūcijas izmanto aptaujas, intervijas, pētijumus kā izziņas rìku, gūstot priekšstatu par klientu vēlmēm un vajadzībām. Sākotnēji šāda izzināšana ir institūciju iniciatīva, tomēr bez mērķgrupas vai personas iesaistīšanās tā nevar realizēties. Iesaistī̌šna un iesaistîšanās ir savstarpēja mijiedarbe un nav iedomājamas bez komunikācijas.

Gan sociālo dienestu, gan institūciju darbinieku ikdienas darbs ar klientiem ietver sarunu. Klientu vēlmju apzināšanas rezultātā var veidoties jaunas iniciatīvas, piemēram, Priekules novada Sociāā atbalsta centra telpās ir izveidoti rokdarbu un kulinārijas pulciṇi, kur aktīvi piedalās arī cilvēki ar invaliditāti. Tie aizsākās ar sociālo pakalpojumu saņēmēju vajadzỉbu izzināšanu, ko veica sociālais dienests un ko var uzskatìt par iesaistī̌̌anu. Tai sekoja iniciatīva darboties interešu grupās jau kā pašu sociālo pakalpojumu saṇēmēju iesaistišanās.

Citu piemēru sniedz institūcijas darbinieki. Regulāro interviju laikā klients izteicis interesi vadìt austrumu cinnu pulciņu. Šì aktivitāte gan neattīstījās kā ilgtspējīga nodarbe, jo pēc pāris vadītām 
nodarbībām klientam un arī dalībniekiem, kas bija iesaistījušies, zuda interese. Tomēr institūcijas darbinieki intervijās uzsver paša procesa nozīmi un vērtīgumu.

Kā labas prakses piemērus var minēt arī personu ar invaliditāti iesaistǐ̌̌anos kā šo personu pašu iniciatīvu sociālo problēmu risināšanā un pakalpojumu sniegšanā. Mērḳtiecības un gribasspēka caurausts stāsts ir par sievieti, kas pēc veselỉbas stāvokḷa pasliktināšanās un invaliditātes statusa nokārtošanas, nespēdama turpināt iepriekš veikto darbu, sāka strādāt par brīvprātīgo sava novada sociālajā dienestā. Vēlāk, papildinot formālo izglìtību, kḷuva par algotu sociālā dienesta darbinieci. Ne tikai iegūtā izglītība, bet arī viņas pašas pieredze kā personai ar invaliditāti šajā darbā ir izrādījusies noderīga.

Liela apn̦ēmība veidot jēgpilnu dzīvi atklājās intervijā ar cilvēku ar II grupas invaliditāti, kurš pats meklē iespējas palīdzēt sev un citiem. Viņš savā novadā ir atradis seniorus, kuriem vajag palīdzēt un kuriem viņš vēlas palīdzēt, - ienest malku, ūdeni, aiziet uz veikalu, apkopt tuvinieku kapus, īsināt laiku sarunās. Par palīdzību viņš parasti saṇem arī nelielu samaksu. Viṇš pats iekopis dārzu puḳēm un audzē dārzeņus pārtikai. Vēlas izremontēt dzīvokli. Tā nav tieša iesaiste sociālo pakalpojumu sniegšanā, tomēr viņš veiksmīgi risina gan savus, gan citu problēmjautājumus un faktiski atvieglo arī sociālā dienesta darbu.

Veicot grupas intervijas šim pētījumam, bija gadījumi, kad iesaistî̌anās problēmsituācijas risināšanā nāca kā mirkḷa iniciatīva. Piemēram, viena persona ar invaliditāti stāstijja par grūtîbām atrast darbu apgūtajā galdnieka profesijā, savukārt cita persona ar invaliditāti uzreiz pēc intervijas šim cilvēkam pasūtìja izgatavot norādes zīmi ar mājas nosaukumu. Šāds gadījums apliecina komunikācijas platformas un sociālo kontaktu nozīmi iesaistīšanas un iesaistīšanās veicināšanai.

Sociālo pakalpojumu saṇēmēju iesaistīšanā aptaujā vai pētījumā ir jāṇem vērā divi riski. Pirmkārt, iespējamo pakalpojuma saṇēmēju nesasniedzamība. Sociālo dienestu darbinieki un institūciju pārstāvji norāda, ka ir problemātiski izzināt vēlmes un vajadzības, iesaistìt aktivitātēs tās personas ar invaliditāti, kurām nav kontakta ar sociālo pakalpojumu sniedzēju. Otrs risks ir nespēja realizēt pakalpojumus atbilstoši izzinātajam un pakalpojumu saṇēmēja gaidām. Te būtiska ir komunikācija un iespēja nodrošināt iesaistîšnonos, diskusija par iespējamiem risinājumiem. 


\section{Secinājumi un ieteikumi}

Personām ar invaliditāti ir tādas pašas vajadzības kā visiem cilvēkiem. Lai šîs vajadzības apmierinātu, šìm personām jāpieliek vairāk pūļu un jāsastopas ar šḳēeṣ̌liem, kas cilvēkus bez funkcionāliem traucējumiem neierobežo. Tādējādi vienādos apstākḷıos veidojas nevienlīdzība.

Personas ar invaliditāti saskaras ar dažādiem šḳēršliem, tādēl ir nepieciešami individuāli risinājumi šḳēršlu pārvarēšanai. Runa ir ne tikai par dažādiem iespējamiem invaliditātes veidiem, bet arī par dažādu individuālo kontekstu.

Valsts institūciju publikācijās jāturpina sakārtot terminu lietojums, runājot par personām ar invaliditāti. Termina "invalīds" lietošana nav piel̦aujama.

Politikas veidošanas dokumentos, likumos un normativiajos aktos jāturpina ANO Konvencijas diskurss, kas uzsver sociālu un vides šḳēršlu pārvarēšanu, nevis indivīda spēju definēšanu.

Rezultatīvo rādītāju izvēle un saskaņotība ar politikas mērḳiem politikas veidošanas dokumentos, piemēram, ANO Konvencijas īstenošanas pamatnostādnēs un monitoringa indikatoru sarakstā, ne vienmēr ir atbilstoša un saskanīga, statistiskie rādītāji strikti būtu jāskata personu ar invaliditāti griezumā.

Politikas veidošanas dokumentos ir atrunāti principi, kas veicina personu ar invaliditāti situācijas uzlabošanu. Labākai politikas realizēšanas uzraudzībai būtu nepieciešama funkcionējoša pārmaiṇu monitoringa nodrošināšana.

Politikas dokumentos cilvēkus ar invaliditāti balstošas iniciatīvas lielākoties ir nākušas no ANO un ES institūcijām, kam ir nozīmīgi finanšu instrumenti šo iniciatīvu isstenošanai. Tās nevar uzskatìt par vērtībām un pārliecību, kas jau stingri nostiprinājusies Latvijas sabiedrībā. Tādēḷ pastiprināti būtu jāvērš uzmanība uz sabiedrības izpratnes veidošanu un sabiedrïbas attieksmes monitoringu.

Būtu vēlams ieviest datu griezumu, kur skatīti nodarijumi tieši pret personām ar invaliditāti Iekšlietu ministrijas Noziedzīgo nodarījumu registra datos; dati šādā griezumā būtu jāskata arī, vērtējot DI plāna realizācijas gaitu un sekas.

Ar ES fondu finanšu instrumentiem cieši saistīto DI plāna realizāciju līdztekus sabiedrības izpratnes un attieksmes jautājumam 
būtiski uzraudzìt, lai savlaicīgi tiktu nodrošināts, ka pēc projekta termiņa beigām neveidojas pārrāvums sabiedrībā balstīto pakalpojumu pieejamībai.

DI plāna realizācija var veicināt to, ka DI iekḷautajām un neiekḷautajām personām ar invaliditāti ir nevienlīdzīgas iespējas un dzìves apstākḷi. Līdztekus jāvērš uzmanība uz pakalpojumu pieejamību tiem cilvēkiem ar invaliditāti, uz kuriem DI plāns neattiecas. ANO Konvencija nosaka visu personu ar invaliditāti tiesības.

Runājot par reproduktīvajām funkcijām, jāvērš uzmanība uz nepieciešamo atbalsta pakalpojumu nodrošināšanu personām ar invaliditāti ar garīga un psihiska rakstura traucējumiem - uz kontracepcijas pieejamību, jaundzimušo bērnu aprūpi. Jautājuma aktualitāte DI plāna kontekstā ievērojami pieaug. Veselības ministrijas SV pamatnostādnès mātes, tēva un bērna veselïba ir viens no galvenajiem rīcības virzieniem, un tajās uzsvērts, ka trūkst zināšanu gan par reproduktīvo veselïbu, gan bērna aprūpi un drošību, kā arī ar to saistìto uzvedības risku. Šo Veselības ministrijas pārraudzìto SV pamatnostādṇu rīcības virzienu būtu būtiski sasaistīt ar Labklājỉbas ministrijas realizējamo DI plānu, lai savlaicīgi plānotu un nodrošinātu nepieciešamos pasākumus.

Cilvēkiem ar invaliditāti jānodrošina iespēja vismaz vienreiz dienā tikt ārpus telpām. To var realizēt, palielinot stundu skaitu valsts vai pašvaldības algotā asistenta pakalpojumam cilvēkiem ar īpaši smagu invaliditāti līdz 20 stundām nedẹlā brīvā laika pavadīšanai. Asistenta pakalpojuma pieejamība pašreizējā apmērā un birokrātisko procedūru kontekstā neveicina personu ar invaliditāti pietiekamu iesaisti sociālajā dzīvē, ārpus institūciju kontaktu realizēšanā un cieņpilnas attieksmes veidošanā.

Politikas veidošanas dokumenti vērš uzmanību uz nepieciešamību paaugstināt nodarbinātības iespējas personām ar invaliditāti, tomēr Darba likumā ietvertā pozitīvā diskriminācija mazina personu ar invaliditāti iespējas iekḷauties darba tirgū. Intervijās sociālo dienestu un institūciju pārstāvji vairāk uzsvēra trūcīgo finansiālo nodrošinājumu personām ar invaliditāti, kamēr pašas personas ar invaliditāti vairāk runāja par vēlmi tikt nodarbinātām, un tas liecina par interesi iesaistīties darba tirgū. Subsidētās darbavietas ir viens no risinājumiem.

Transporta pieejamība lauku reǵionos ir būtisks faktors, kas nosaka personu ar invaliditāti iespējas iesaistīties jebkurās sociālās aktivitātēs un saṇemt sociālos pakalpojumus, tai skaitā saistībā ar 
nodarbinātību un veselības aprūpi. Pašreiz pieejamie transporta pakalpojumi nerada vienlīdzīgus un iekḷaujošus apstākḷus personām ar invaliditāti, it sevišḳi lauku reǵionos.

Sabiedrības veselības aprūpes trūkumi tieši skar personas ar invaliditāti. Stratēgijas "Eiropa 2020" rekomendācijas ir ieviešamas, būtu vēlama to izpildes kvalitātes kontrole.

SV pamatnostādṇu izstrādē būtu jāṇem vērā, ka atkarības izraisa ne tikai atkarību izraisošas vielas, bet arī azartspēles, paredzot attiecīgus rīcības virzienus sabiedrības veselības spēcināšanai.

Personu ar invaliditāti iesaistî̌ana un iesaistišsanās sociālo pakalpojumu sniegšanā un problēmsituāciju risināšanā ir vērtīga prakse, ko var veicināt komunikācijas platformas un sociālo kontaktu stiprināšana kopienā.

Kaut arī empīriskais pētījums veikts tikai atsevišķos Kurzemes regiiona novados, tomēr ir pamats uzskatìt, ka līdzīgi rezultāti būtu arī citos Latvijas regionos un novados.

\section{Atsauces}

Altum (2017) Sociālā uzņēmējdarbība. Pieejams: https://www.altum.lv/lv/ pakalpojumi/biznesa-uzsacejiem/socialas-uznemejdarbibas-programma/parprogrammu/ [skatîts: 28.12.2017.].

Altum (b.g.) Valsts attīstîbas finanšu institūcija. Pieejams: https://www.altum. lv/lv/par-altum/kas-mes-esam/ [skatits: 28.12.2017.].

ANO (2006) Apvienoto Nāciju Organizācijas konvencija par personu ar invaliditāti tiesībām. Pieejams: https://likumi.lv/ta/lv/starptautiskie-ligumi/id/1630 [skatìts: 28.12.2017.].

Apeirons (2011) Cilvēkiem ar invaliditāti būs jauna parauga apliecības. Pieejams: http://www.apeirons.lv/new/?page $=1 \&$ sub=25\&id_cont=1591 [skatits: 28.12.2017.].

Bagenstos, S. R. (2012) The Past and Future of Deinstitutionalization Litigation. Available: http://repository.law.umich.edu/cgi/viewcontent.cgi? article $=1156 \&$ context=law_econ_current [accessed: December 28, 2017].

Bahmane, D. (2018) Veselíbas ekonomikas loma mūsdienu veselības aprūpes sistēmā. Latvijas Ārsts, Nr. 1, 2018, 76.-78. lpp.

Baikovska, B. (2017) Invaliditātes jēdziena lietojums Latvijā un starptautiski atškirīgais un kopīgais. Pieejams: https://www.youtube.com/watch?v=hO43-fPK4PA [skatīts: 28.12.2017.].

Blum, R. et al. (2001) Health-Risk Behaviors and Protective Factors among Adolescents with Mobility Impairments and Learning and Emotional Disabilities. Available: https://doi.org/10.1016/S1054-139X(01)00201-4 [accessed: December 28, 2017]. 
Centrālā statistikas pārvalde (2017a) Nabadzības riskam Latvijā pakḷauti 424 tūkstoši jeb 21,8\% iedzīvotāju. Pieejams: http://www.csb.gov.lv/notikumi/nabadzibas-riskam-latvija-paklauti-424-tukstosi-jeb-218-iedzivotaju-45823.html [skatīts: 28.12.2017.].

Centrāāā statistikas pārvalde (2017b) SP SDG04. Pensiju saṇēmēju skaita sadalījums pēc pensijas vidējā pieškirtā apmēra. Pieejams: http://data.csb.gov.lv/api/ v1/lv/Sociala/ikgad/socdr/SD0040_euro.px [skatīts: 28.12.2017.].

Centrālā statistikas pārvalde (b.g.) Iedzīvotāji un sociālie procesi. Pieejams: http://data.csb.gov.lv/pxweb/lv/Sociala/Sociala_ikgad__veseliba/?tablelist=tru e\&rxid=cdcb978c-22b0-416a-aacc-aa650d3e2ce0 [skatits: 28.12.2017.].

Delfi (2017) Veselības ministrija cenzē izstādes "Neredzamās zonas" plakātu. Pieejams: http://www.delfi.lv/kultura/news/culturenvironment/veselibasministrija-cenze-izstades-neredzamas-zonas-plakatu.d?id=48945603 [skatīts: 28.12.2017.].

Doda, D. et al. (2010) Invaliditāte jaunā skatijumā. Pieejams: http://www.bms. edu.lv/wp-content/uploads/2013/07/invaliditate_jauna_skatijuma.pdf [skatīts: 28.12.2017.].

Eiropas Padome (1961) Eiropas Sociālā harta. Pieejams: https://likumi.lv/ta/lv/ starptautiskie-ligumi/id/1045 [skatīts: 28.12.2017.].

European Commission (2012) Common European Guidelines on the Transition from Institutional to Community Based Care. Available: http://www.deinstitutionalisationguide.eu/ [accessed: December 28, 2017].

European Commission (2017) European Semester: Country Specific Recommendation / Commission Recommendations - Latvia. Available: https://ec. europa.eu/info/files/2017-european-semester-country-specific-recommendation-commission-recommendations-latvia_en [accessed: December 28, 2017].

European Commission (n.d.) Europe 2020. The European Semester. Latvia. Available: http://ec.europa.eu/europe2020/europe-2020-in-a-nutshell/index_lv. htm [accessed: December 28, 2017].

Finklestein, V., Stuart, O. (1996) Developing New Services. In: Beyond Disability: Towards an Enabling Society. London: Sage Publications.

Hagerty, M. R. (1999) Testing Maslow's Hierarchy of Needs: National Quality of Life Across Time. In: Social Indicators Research. Vol. 46, pp. 249-271. Doi: 10.1023/A:1006921107298.

Hazans, M., Kḷave E., Zepa B. (2014) Pētijums par pretdiskriminācijas politikas uzraudzības sistēmas izstrādi. Pieejams: http://www.sif.gov.lv/images/files/SIF/ progress-dazadiba/Petijums_diskr_final.pdf [skatīts: 28.12.2017.].

Iekšlietu ministrija (b.g.) Informācija par nozares politikas dokumentiem. Pieejams: http://www.iem.gov.lv/lat/nozare/nozares_politikas_dokumenti/ [skatìts: 28.12.2017.].

Izglìtības un zinātnes ministrija (2004) Profesijas standarts: aprūpētājs. Pieejams: http://visc.gov.lv/profizglitiba/dokumenti/standarti/ps0259.pdf [skatīts: 28.12.2017.]. 
Izglītības un zinātnes ministrija (2013) Izglītības attīstības pamatnostādnes 2014.-2020. gadam. Pieejams: https://m.likumi.lv/doc.php?id=266406 [skatîts: 28.12.2017.].

Izglīiības un zinātnes ministrija (2016) Izglìtības politikas prioritātes un veicamās reformas izglìtībā. Pieejams: http://www.izm.gov.lv/images/OECD/ IZM_reformas_200516.pdf [skatīts: 28.12.2017.].

Kim, Dae-Young (2014) Psychiatric Deinstitutionalization and Prison Population Growth: A Critical Literature Review and Its Implications. Doi: 10.1177/0887403414547043.

Labklājības ministrija (2014) Koncepcija "Par sociālās uzṇēmējdarbības ieviešanas iespējām Latvijā”. Pieejams: http://www.lm.gov.lv/upload/aktualitates/null/ lmkonc_271014_su_1_1807.pdf [skatīts: 28.12.2017.].

Labklājības ministrija (2015a) Augulis: asistentu pakalpojums cilvēkiem ar invaliditāti nekavējoties jāpilnveido. Pieejams: http://www.lm.gov.lv/news/id/ 6345 [skatīts: 28.12 .2017$.$] .$

Labklājības ministrija (2015b) Rīcības plāns DI īstenošanai 2015.-2020. gadam. Pieejams: http://www.lm.gov.lv/upload/aktualitates/null/2015_15_07_ricplans_ final.pdf [skatīts: 28.12.2017.].

Labklājības ministrija (2017a) Indikatoru saraksts ANO Konvencijas par personu ar invaliditāti tiesībām monitoringam. Pieejams: http://www.lm.gov. lv/upload/invaliditate/indikatori_publicesanai_16082017_preciz_2.pdf [skatīts: 28.12.2017.].

Labklājības ministrija (2017b) Pētījums par starptautisko praksi personu ar invaliditāti atbalsta sistēmu jomā. Pieejams: http://petijumi.mk.gov.lv/sites/ default/files/title_file/petijums_LM_par_starptautisko_praksi_personu_ar_invalid_atbalsta_sistema_joma.pdf [skatīts: 28.12.2017.].

Labklājības ministrija (b.g.a) Invaliditātes noteikšana. Pieejams: https://www. lm.gov.lv/text/155 [skatits: 28.12.2017.].

Labklājības ministrija (b.g.b) Invaliditātes pensija. Pieejams: http://www.lm.gov. lv/text/134 [skatīts: 28.12.2017.].

Labklājības ministrija (b.g.c) Personām ar invaliditāti. Pieejams: https://www. lm.gov.lv/text/54 [skatīts: 28.12.2017.].

Labklājības ministrija (b.g.d) Sociālā uzṇēmējdarbība. Pieejams: http://www. lm.gov.lv/text/3091 [skatits: 28.12.2017.].

Labklājības ministrija (b.g.e) Sociālās rehabilitācijas pakalpojumi personām ar funkcionāliem traucējumiem un personām ar prognozējamu invaliditāti. Pieejams: http://www.lm.gov.lv/text/2569 [skatīts: 28.12.2017.].

Lamb, H. R., Bachrach, L. L. (2001) Some Perspectives on Deinstitutionalization. Available: https://doi.org/10.1176/appi.ps.52.8.1039 [accessed: December 28, 2017].

Latvijas Kustība par neatkarīgu dzīvi (2010) Ziņojums par cilvēku ar funkcionāliem traucējumiem vajadzību iekḷāvumu nacionālos un regionālos plānošanas dokumentos. Pieejams: http://www.sif.gov.lv/nodevumi/nodevumi/3264/ Zinojums_1.pdf [skatīts: 28.12.2017.]. 
Latvijas Republikas Satversme (1918) Pieejams: http://www.saeima.lv/lv/likumdosana/satversme [skatîts: 28.12.2017.].

Latvijas Republikas tiesībsargs (2014). Latvijas iedzīvotāju aptauja par personu ar invaliditāti tiesībām. Pieejams: http://www.tiesibsargs.lv/uploads/content/ legacy/ANO_invaliditates_konvencija_Latvijas_iedzivotaju_aptauja_2014.pdf [skatits: 28.12.2017.].

Latvijas Sabiedriskie Mediji (2017) Mediķus darbam reg̣ionos vilinās ar kompensācijām. Pieejams: http://www.lsm.lv/raksts/zinas/latvija/medikus-darbamregionos-vilinas-ar-kompensacijam.a229078/ [skatīts: 28.12.2017.].

Maslow, A. H. (1943) A Theory of Human Motivation. Psychological Review. Vol. 50(4), pp. 370-396. Doi: 10.1037/h0054346.

Maslow, A. H. (1954) Motivation and Personality. New York: Harper and Row. Maslow, A. H. (1970) Religions, Values, and Peak Experiences. New York: Penguin.

Ministry of Welfare (2016) Action Plan for Implementation of Deinstitutionalisation 2015-2020. Available: http://vvc.gov.lv/image/catalog/dokumenti/ Implementation_of_Deinstitutionalisation_2015-2020.pdf [accessed: May 7, 2018].

MK (1997) Ministru kabinets noteikumi Nr.138. Pieejams: https://ikumi.lv/ doc.php?id=42990 [skatīts: 28.12 .2017 .].

MK (2009a) Ministru kabineta noteikumi Nr. 279. Pieejams: https://likumi.lv/ doc.php?id=190188 [skatîts: 28.12 .2017 .].

MK (2009b) Ministru kabineta noteikumi Nr. 1472. Pieejams: https://likumi.lv/ doc.php?id=202630 [skatīts: 28.12 .2017 .].

MK (2009c) Ministru kabineta noteikumi Nr. 1605. Pieejams: https://likumi.lv/ doc.php?id=202850 [skatīts: 28.12 .2017 .].

MK (2010a) Ministru kabineta noteikumi Nr. 1170. Pieejams: https://likumi.lv/ doc.php?id=223578 [skatīts: 28.12.2017.].

MK (2010b) Ministru kabineta noteikumi Nr. 1207. Pieejams: https://likumi.lv/ doc.php?id=223793 [skatìts: 28.12 .2017 .].

MK (2010c) Ministru kabineta noteikumi Nr. 1208. Pieejams: https://likumi. lv/ta/id/223858-noteikumi-par-psihologa-pakalpojuma-apjomu-personai-lidz18-gadiem-kurai-pirmreizeji-noteikta-invaliditate-un-kura-dzivo-gimene... [skatīts: 28.12.2017.].

MK (2011a) Ministru kabineta noteikumi Nr. 9. Pieejams: https://likumi.lv/ta/ id/224135-noteikumi-par-individualo-rehabilitacijas-planu-personai-ar-prognozejamu-invaliditati-un-personai-ar-invaliditati [skatīts: 28.12.2017.].

MK (2011b) Ministru kabineta noteikumi Nr. 170. Pieejams: https://ikumi.lv/ ta/id/227323-noteikumi-par-darbibas-programmas-cilvekresursi-un-nodarbinatiba-papildinajuma-1-4-1-1-1-apaksaktivitati-kompleksi-atbalsta-pas... [skatīts: 28.12.2017.].

MK (2012a) Ministru kabineta noteikumi Nr. 450. Pieejams: https://ikumi.lv/ ta/id/249985-noteikumi-par-invaliditati-apliecinosa-dokumenta-paraugu-dokumenta-izsniegsanas-un-uzskaites-kartibu [skatīts: 28.12.2017.]. 
MK (2012b) Ministru kabineta noteikumi Nr. 599. Pieejams: https://likumi.lv/ doc.php?id=251480 [skatīts: 28.12 .2017 .].

MK (2012c) Ministru kabineta noteikumi Nr. 695. Pieejams: https://likumi.lv/ ta/id/252140-kartiba-kada-pieskir-un-finanse-asistenta-pakalpojumu-izglitibas-iestade [skatīts: 28.12.2017.].

MK (2012d) Ministru kabineta noteikumi Nr 942. Pieejams: http://likumi.lv/ doc.php?id=253781\#piel1\&pd=1 [skatīts: 28.12.2017.].

MK (2014a) Ministru kabineta noteikumi Nr. 698. Pieejams: https://likumi.lv/ ta/id/270262-noteikumi-par-pabalstu-par-asistenta-izmantosanu-personamar-i-grupas-redzes-invaliditati [skatīts: 28.12.2017.].

MK (2014b) Ministru kabineta noteikumi Nr. 805. Pieejams: https://likumi. $\mathrm{lv} / \mathrm{ta} / \mathrm{id} / 271253$-noteikumi-par-prognozejamas-invaliditates-invaliditates-undarbspeju-zaudejuma-noteiksanas-kriterijiem-terminiem-un-kartibu [skatits: 28.12.2017.].

MK (2015) Ministru kabineta noteikumi Nr. 313. Pieejams: https://likumi.lv/ doc.php?id=274957 [skatîts: 28.12 .2017 .].

MK (2017) Ministru kabineta noteikumi Nr. 94. Pieejams: https://likumi.lv/doc. php?id=288897 [skatīts: 28.12 .2017$.$] .$

Nacionālais veselības dienests (2016) Veselības tīklu attīstības vadlīniju un kvalitātes nodrošināšanas sistēmas izstrāde un ieviešana prioritāro veselības jomu ietvaros. Pieejams: http://vmnvd.gov.lv/lv/esf-projekts [skatīts: 28.12.2017.].

Nodarbinātības valsts aǵentūra (2017) Projekts Nr. 9.1.1.1./15/I/001. Subsidētās darbavietas bezdarbniekiem. Pieejams: http://www.nva.gov.lv/index. php?cid $=2 \&$ mid $=511 \& t x t=4146$ [skatîts: 28.12 .2017 .].

Obosi, S. (2010) Disability-Friendly Language: Human Rights Imperative or Game of Linguistic Leapfrog? United Kingdom: Frome.

Orupe, A. (2017) Speciālā izglītība reformas gaidās. Pieejams: http://nra.lv/ latvija/izglitiba-karjera/207662-speciala-izglitiba-reformas-gaidas.htm [skatīts: 28.12.2017.].

Paparde, I. (2017) Vien 24\% cilvēku ar invaliditāti Latvijā ir nodarbināti. Pieejams: http://nra.lv/ekonomika/latvija/222315-vien-24-cilveku-ar-invaliditatilatvija-ir-nodarbinati.htm [skatìts: 28.12.2017.].

Paula Stradiṇa Medicinas vēstures muzejs (2017) A. Žmijevskis (Polija). Neredzamās zonas. Pieejams: http://www.mvm.lv/lv/pasakumi/?pas=231 [skatīts: 28.12.2017.].

Perry, B. L. (2016) 50 Years After Deinstitutionalization: Mental Illness in Contemporary Communities. Advances in Medical Sociology. Vol. 17.

Pescosolido, B. (2013) The Public Stigma of Mental Illness: What Do We Think; What Do We Know; What Can We Prove? Doi: 10.1177/0022146512471197.

Saeima (1995b) Par maternitātes un slimības apdrošināšanu. Pieejams: https:// likumi.lv/doc.php?id=38051 [skatîts: 28.12.2017.].

Saeima (1995c) Par sociālo drošību. Pieejams: https://likumi.lv/doc.php?id= 36850 [skatīts: 28.12.2017.]. 
Saeima (1997a) Ārstniecības likums. Pieejams: https://likumi.lv/doc.php?id= 44108 [skatīts: 28.12.2017.].

Saeima (1997b) Par valsts sociālo apdrošināšanu. Pieejams: https://likumi.lv/ doc.php?id=45466 [skatīts: 28.12 .2017 .].

Saeima (1998) Civilprocesa likums, 72. panta pirmā dal̦a. Pieejams: https://likumi.lv/doc.php?id=50500 [skatīts: 28.12.2017.].

Saeima (2001a) Darba likums. Pieejams: https://likumi.lv/doc.php?id=38051 [skatîts: 28.12.2017.].

Saeima (2001b) Par Eiropas Sociālo hartu. Pieejams: https://www.vestnesis.lv/ ta/id/56569-par-eiropas-socialo-hartu [skatīts: 28.12.2017.].

Saeima (2002a) Sociālo pakalpojumu un sociālās palīdzības likums. Pieejams: https://likumi.lv/doc.php?id=68488 [skatīts: 28.12.2017.].

Saeima (2002b) Valsts sociālo pabalstu likums. Pieejams: https://likumi.lv/doc. php?id=68483 [skatīts: 28.12 .2017 .].

Saeima (2006) Konvencija par personu ar invaliditāti tiesībām. Pieejams: https://likumi.lv/ta/lv/starptautiskie-ligumi/id/1630 [skatīts: 28.12.2017.].

Saeima (2010a) Invaliditātes likums. Pieejams: https://m.likumi.lv/doc.php?id= 211494 [skatīts: 28.12.2017.].

Saeima (2010b) Latvijas ilgtspējīgas attīstības stratēgija līdz 2030. gadam. Pieejams: http://polsis.mk.gov.lv/documents/3323 [skatits: 28.12.2017.].

Saeima (2012) Pieejams: http://polsis.mk.gov.lv/documents/4525 [skatīts: 28.12.2017.].

Saeima (2013a) Apvienoto Nāciju Organizācijas Konvencijas par personu ar invaliditāti tiesībām īstenošanas pamatnostādnes 2014.-2020. gadam. Pieejams: http://www.lm.gov.lv/upload/2013junijs/lmpamn_040613_inv.pdf [skatīts: 28.12.2017.].

Saeima (2013b) Latvijas Nacionālais attīstības plāns 2014.-2020. gadam. Pieejams: http://polsis.mk.gov.lv/documents/4247 [skatits: 28.12.2017.].

Saeima (2013c) Sabiedrības veselības pamatnostādnes 2014.-2020. gadam. Pieejams: http://polsis.mk.gov.lv/documents/4965 [skatits: 28.12.2017.].

Saeima (2013d) Pamatnostādnes sociālo pakalpojumu attīstībai 2014.-2020. gadam. Pieejams: http://www.lm.gov.lv/upload/aktualitates2/lmpam_290713_ sp.pdf [skatìts: 28.12.2017.].

Saeima (2013e) Profesionālā sociālā darba attīstîbas pamatnostādnes 2014.2020. gadam. Pieejams: http://www.lm.gov.lv/upload/tiesibu_aktu_projekti_2/ iesibu_aktu_projekti_3/lmpamatn_140613_sd.pdf [skatīts: 28.12.2017.].

Saeima (2013f) Transporta attīstības pamatnostādnes 2014.-2020. gadam. Pieejams: http://www.sam.gov.lv/images/modules/items/PDF/item_4174_SAMpamn_030713_transp.1pdf.pdf [skatīts: 28.12.2017.].

Saeima (2015) Rīcības plāns deinstitucionalizācijas īstenošanai 2015.-2020. gadam. Pieejams: http://www.lm.gov.lv/upload/aktualitates/null/2015_15_07_ricplans_final.pdf [skatîts: 28.12.2017.]. 
Saeima (2016) Saeimā diskutē par ekonomiskās neatkarības veicināšanu cilvēkiem ar invaliditāti. Pieejams: http://www.saeima.lv/lv/aktualitates/saeimaszinas/25398-saeima-diskute-par-ekonomiskas-neatkaribas-veicinasanu-cilvekiem-ar-invaliditati [skatīts: 28.12.2017.].

Saeima (2017a) Sociālā uzņēmuma likums. Pieejams: https://likumi.lv/doc. php?id=294484 [skatīts: 28.12.2017.].

Saeima (2017b). Grozījumi darba likumā. Pieejams: https://www.vestnesis.lv/ op/2017/152.3 [skatīts: 28.12.2017.].

Satiksmes ministrija (b.g.) Pasažieru tiesības un pienākumi. Pieejams: http:// www.sam.gov.lv/sm/content/?cat=259 [skatits: 28.12 .2017$.$] .$

Sisti, D. A., Segal, A. G., Emanuel, E. J. (2015) Improving Long-term Psychiatric Care Bring Back the Asylum. Doi:10.1001/jama.2014.16088.

Strapcāne, A. (2017) Ārstus aicinās griezt muguru Rīgai. Pieejams: https:// www.diena.lv/raksts/latvija/zinas/arstus-aicinas-griezt-muguru-rigai-14167580 [skatīts: 28.12.2017.].

Sustento (b.g.) Latvijas Cilvēku ar īpašām vajadzībām sadarbības organizācija. Pieejams: http://www.sustento.lv/ [skatīts: 28.12.2017.].

Tay, L., Diener, E. (2011) Needs and Subjective Well-Being Around the World. Journal of Personality and Social Psychology. Vol. 101(2), p. 354.

Thielke, S., Harniss, M., Thompson, H. et al. (2012) Maslow's Hierarchy of Human Needs and the Adoption of Health-Related Technologies for Older Adults, p. 470. Available: https://doi.org/10.1007/s12126-011-9121-4 [accessed: December 28, 2017].

United Nations (n.d.) Convention on the Rights of Persons with Disabilities. Available: https://www.un.org/development/desa/disabilities/convention-onthe-rights-of-persons-with-disabilities.html [accessed: December 28, 2017].

Vahḷina, T. (2011) Ziṇojums par cilvēku ar funkcionāliem traucējumiem vajadzību iekḷāvumu nacionālos un reǵionālos plānošanas dokumentos. Pieejams: http://www.sif.gov.lv/nodevumi/nodevumi/3264/Zinojums_1.pdf [skatìts: 28.12.2017.].

Valsts kontrole (2015) Valsts kontroles revizijas ziņojums. Vai personām ar invaliditāti paredzētais asistenta pakalpojums nodrošina tā izveidošanas mērķu sasniegšanu? Pieejams: http://www.lrvk.gov.lv/uploads/reviziju-zinojumi/2015/2.4.1-10_2015/ksav_invasistenti.pdf [skatīts: 28.12.2017.].

VDEĀVK (2017) Veselības un darbspējas ārstu valsts komisijas publiskais pārskats par 2016. gadu. Pieejams: http://www.vdeavk.gov.lv/wp-content/uploads/2014/09/Parskats_2016_1.puse_www.pdf [skatīts: 28.12.2017.].

VDEĀVK (b.g.) Veselības un darbspējas ārstu valsts komisija. Pieejams: http:// www.vdeavk.gov.lv/ [skatits: 28.12.2017.].

Veselības ministrija (2016) 9.2.5. specifiskā atbalsta mērḳa "Uzlabot pieejamību ārstniecības un ārstniecības atbalsta personām, kas sniedz pakalpojumus prioritārajās veselības jomās iedzīvotājiem, kas dzīvo ārpus Rīgas" sākotnējais novērtējums. Pieejams: https://esfondi.vm.gov.lv/lat/aktualitates/20102016_specifiska_atbalsta_merki_932_un_925/ [skatīts: 28.12.2017.]. 
Veselibas ministrija (2017) Par veselibas aprūpes reformu. Pieejams: http:// www.vm.gov.lv/lv/aktualitates/zinojums_par_veselibas_aprupes_sistemas_reformu/ [skatits: 28.12.2017.].

Vīnbergs, V. (2017) Ķermeṇa jautājums. Pieejams: https://www.rigaslaiks.lv/ agora/ekphrasis/kermena-jautajums-19084 [skatits: 28.12.2017.].

World Health Organisation (2012) European Mental Health Action Plan 2013. Available: http://www.euro.who.int/en/health-topics/noncommunicable-diseases/mental-health/publications/2013/the-european-mental-health-action-plan [accessed: December 28, 2017].

World Health Organisation (n.d.) Services and Deinstitutionalization. Available: http://www.euro.who.int/en/health-topics/noncommunicable-diseases/ mental-health/priority-areas/services-and-deinstitutionalization [accessed: December 28, 2017]. 
1. pielikums

\section{Politikas veidošanas dokumenti, kas attiecas uz personām ar invaliditāti}

- Latvijas Republikas Satversme (1918)

Latvijas Republikas Satversmes 91. pants noteic, ka "Visi cilvēki Latvijā ir vienlīdzīgi likuma un tiesas priekšā. Cilvēka tiesības tiek īstenotas bez jebkādas diskriminācijas" (Latvijas Republikas Satversme, 1918). Satversme ir valsts pamatlikums ar augstāko juridisko spēku.

- ANO Konvencija par personu ar invaliditāti tiesībām (ANO, 2006)

Nozīmīga, jo tā ir starptautiska vienošanās, kas Latvijas valstij ir saistoša. ANO Konvencija ir nozīmīgākais un apjomīgākais politiskais dokuments, kas tieši attiecināms uz personām ar invaliditāti: "Šās konvencijas mērḳis ir veicināt, aizsargāt un nodrošināt to, lai visas personas ar invaliditāti varētu pilnībā un vienlīdzīgi izmantot visas cilvēktiesības un pamatbrīvỉbas, un veicināt tām piemîtošās cieņas ievērošanu." (ANO, 2006, 1. pants) Konvencija pieļauj tajā ietverto tiesību pakāpenisku īstenošanu. Latvija Konvenciju pieņēmusi 2006. gadā un ratificējusi 2010. gadā (Saeima, 2006); 2013. gadā izstrādātas Konvencijas īstenošanas pamatnostādnes.

ANO Konvencijā atsevišķos pantos skatīti šādi problēmjautājumi jeb rīcības virzieni (5.-32. pants): vienlīdzība un diskriminācijas aizliegums; sievietes ar invaliditāti; bērni ar invaliditāti; izpratnes veidošana; pieejamība; tiesības uz dzīvỉbu; riska situācijas un ārkārtas humānās situācijas; vienlīdzīga tiesībspējas atzī̌̌ana; tiesas pieejamība; personas brīvība un neaizskaramība; tiesības netikt pakḷautam spīdzināšanai vai nežělīgiem, necilvēcīgiem vai cieņu pazemojošiem apiešanās un sodī̌sanas veidiem; tiesības netikt paḳlautam ekspluatācijai, vardarbībai un l̦aunprātīgai izmantošanai; personas integritātes aizsardzība; pārvietošanās un pilsonības brīvība; patstāvīgs dzīvesveids un ieḳ̣aušana sabiedrībā; individuālā pārvietošanās; vārda un uzskatu brīvība un pieeja informācijai; privātās dzīves neaizskaramība; cieņa pret dzīvesvietu un gimeni; izglìtîba; veselība; adaptācija un rehabilitācija; darbs un nodarbinātîba; pienācīgs dzīves līmenis un sociālā aizsardzība; līdzdalība politiskajā un sabiedriskajā dzīvē; līdzdalība kultūras dzīvē, atpūta, brīvā laika pavadīšana un sports; statistika un datu vākšana; starptautiskā sadarbība.

Vajadzību izpētes kontekstā ANO Konvencija un ar to saistītie dokumenti ir nozīmīgi, jo skaidri iezīmē pāreju uz invaliditātes sociālo jeb 
cilvēktiesību modeli. Tajos tiek akcentēta ārējo šķēršşu ietekmes mazināšana un tādas vides veidošana (ieskaitot sociālo vidi), kurā personas ar invaliditāti var realizēt savas iespējas un apmierināt savas vajadzības.

- Apvienoto Nāciju Organizācijas Konvencijas par personu ar invaliditāti tiesībām îstenošanas pamatnostādnes 2014.-2020. gadam (Saeima, 2013a)

Vidēja līmeṇa politikas plānošanas dokuments, kas izstrādāts, lai īstenotu ANO Konvencijā izvirzītos mērķus un veicamos uzdevumus. Dokumentā raksturota pašreizèjā situācija un formulētas problēmas, definēti invaliditātes politikas pamatprincipi un mērḳi, kā arī noteikti prioritārie rīcības virzieni, konkrēti apakšmērḳi šo rīcības virzienu ietvarā, uzdevumi mērḳu sasniegšanai, sagaidāmie politikas rezultāti un izmērāmi rezultatīvie rādìtāji. Latvijā ir šādi prioritāri rīcības virzieni un mērḳi:

(1) izglìitiba - veicināt bērnu ar invaliditāti iekḷaušanos visās izglìtîbas pakāpēs un veidos atbilstoši personas ar invaliditāti spējām;

(2) darbs un nodarbinātîba - veicināt personu ar invaliditāti iekḷaušanu darba tirgū, sniedzot attiecīgu atbalstu, ņemot vērā personas ar invaliditāti funkcionālo traucējumu veidu;

(3) sociālā aizsardzība - nodrošināt, ka ikviena persona ar invaliditāti saņem mērķtiecīgu un efektīvu valsts atbalstu atbilstoši personas funkcionālā traucējuma veidam;

(4) sabiedrības izpratne - nodrošināt personu ar invaliditāti iespējas izmantot tās pašas cilvēktiesības kā pārējiem un dzīvot pilnvērtīgu un cieņpilnu dzīvi (Saeima 2013a).

Mērḳos minētie funkcionālā traucējuma veidi definēti šādi: (1) kustību traucējumi; (2) redzes traucējumi; (3) dzirdes traucējumi; (4) garīga rakstura traucējumi un "neredzamā invaliditāte", piemēram, sirds, plaušu un asinsvadu slimības, dažādu orgānu bojājumi un traucējumi (Saeima, 2013a, 11). ANO Konvencijā (ANO, 2006) minētie funkcionālo traucējumu veidi ir fiziski, garīgi, intelektuāli un maņu traucējumi.

- Indikatoru saraksts ANO Konvencijas par personu ar invaliditāti tiesībām monitoringam (Labklājības ministrija, 2017a)

Labklājības ministrija to publicējusi 2017. gada augustā. Dokuments nozīmīgs, jo nosauc indikatorus, kas izvirzīti ANO Konvencijas (ANO, 2006) 5.-30. panta problēmjautājumu monitoringam; indikatoriem lielākoties norādīts avots, pētnieka komentārs un aptauju dati. Monitoringa dokumentā ietvertā informācija gan atsevišķos punktos vieš jautājumu par šĩ dokumenta kvalitāti. Piemēram, pirmais indikators dokumentā ir sociālā distance kopienā, kur kā rādītājs skatīts to iedzīvotāju īpatsvars, kuri izjustu diskomfortu, ja vinu apkaimē dzìvotu persona ar invaliditāti. Attiecīgi bez precīzas 
atsauces pievienoti tiesībsarga pētijumā iegūtie rezultāti, kas šajā dokumentā publicēti šãdi: "2\% Latvijas iedzīvotāju izjustu diskomfortu, ja apkaimē vai kaimiņos dzīvotu cilvēki ar kustîbu, redzes vai dzirdes traucējumiem, 3\% ja dzīvotu cilvēki ar ilgstošiem veselības traucējumiem, 10\%, ja dzīvotu ar intelektuālās attīstîbas traucējumiem, bet 17\%, ja dzīvotu cilvēki ar psihiskām saslimšanām." (Labklājības ministrija, 2017a, 2)

Tiesībsargs sadarbībā ar mārketinga pētījumu uzṇēmumu - SIA Factum - šādu pētijumu ir veicis 2014. gadā (Latvijas Republikas tiesībsargs, 2014), tomēr tiesībsarga mājaslapā publicētie pētījuma rezultāti norāda uz būtiski atškirīgiem skaițiem. Pētnieku uzdotajam jautājumam "Attieksme pret cilvēkiem ar invaliditāti kaimiņos: vai Jūs izjustu vai neizjustu traucējumu vai diskomfortu, ja Jūsu apkaimē vai kaimiņos dzīvotu šādi cilvēki?" (Latvijas Republikas tiesībsargs, 2014, 21) atbilžu skala ir piedāvāta šādā gradācijā: "nē, neizjustu traucējumu", "drīzāk nē", "drīzāk jā", "jā, izjustu traucējumu”. Rezultātu analīzē tādā griezumā, kā tas parādās monitoringa dokumentā, korekti būtu skatīt abu veidu apstiprinošo atbilžu (gan "drīzāk jā", gan "jā, izjustu traucējumu") rezultātus kopā; tāpat arī būtu vēlams pētnieka komentārs par sociāli vēlamu atbilžu sniegšanas praksi.

- Latvijas ilgtspējiggas attīstības stratēgija līdz 2030. gadam ("Latvija 2030") (Saeima, 2010b)

Nozīmīgs kā valsts galvenais plānošanas dokuments. Šis un turpmākie valsts plānošanas dokumenti cilvēku ar invaliditāti vajadzību realizēšanā ir būtiski, jo nosaka stratēgiju, kas tieši ietekmē vidi, kurā tiesību, brīvību un arī vajadzību realizēšana saskaras vai nesaskaras ar šķēerșliem.

Cilvēki ar invaliditāti minēti deviṇos dokumenta paragrāfos par šādām satura tēmām:

(86) darba tirgus elastîbas un nodarbinātības drošības jeb elastdrošības veicināšana;

(118) darba tirgus pieejamība un diskriminācijas mazināšana;

(125) atbalsts uzṇēmumiem un nevalstiskajām organizācijām, kas īsteno diskriminācijas novēršanas pasākumus;

(126) sabiedrības informēšana par sociālo dažādību;

(128) sociālās programmas nabadzības un sociālās atstumtîbas riskam pakḷautajām iedzīvotāju grupām;

(130) vides un informācijas pieejamība cilvēkiem ar funkcionāliem traucējumiem;

(134) iekḷaujoša izglìtíba;

(165) atvērtā universitāte;

(306) ar interneta pieejamību saistīti atbalsta pakalpojumi ceḷotājiem ar funkcionāliem traucējumiem. 
Kopumā valsts galvenais plānošanas dokuments vērš uzmanību uz vides šķērš̀u mazināšanu personām ar invaliditāti.

- Stratēgija "Eiropa 2020" (European Commission, n.d.)

Šo ES darbavietu radǐšanas un izaugsmes desmit gadu stratēgiju sāka isstenot 2010. gadā, lai radītu apstākḷus gudrai, ilgtspējīgai un iekḷaujošai izaugsmei. Tās pamatmērkị, kas jāsasniedz līdz 2020. gada beigām, attiecas uz nodarbinātību, pētniecību un izstrādi, klimatu un energètiku, izglîtību, sociālo iekḷautību un nabadzības mazināšanu. Sociālā iekḷautība attiecināma uz darbu un izglìīibu un spēcina cilvēku ar invaliditāti tiesỉbas. ES dalībvalstu ekonomiskajām un sociālajām reformām jābūt saskaņotām ar stratēgijas "Eiropa 2020" mērkiem.

Saistībā ar personu ar invaliditāti nodarbinātību te jāmin, ka 2017. gadā ir pieņemts un 2018. gadā ir stājies spēkā Sociālā uzṇēmuma likums (Saeima, 2017a). Tā mērḳis ir "veicināt sabiedrības dzīves kvalitātes uzlabošanu un sekmēt sociālās atstumtības riskam pakḷauto iedzīvotāju grupu (turpmāk mērķa grupa) nodarbinātību, radot sociālajiem uzņēmumiem labvēlīgu saimnieciskās darbības vidi” (Saeima, 2017a). Sociālās uzṇēmējdarbības atbalstam līdz 2022. gadam pieejams ES atbalsts 12 miljonu eiro apmērā (Altum, 2017). Sociālā uzṇēmējdarbība, iespējams, ir perspektīvs instruments nodarbinātības veicināšanai personām ar invaliditāti.

- Latvijas Nacionālais attīstības plāns 2014.-2020. gadam (“NAP 2020") (Saeima, 2013b)

Nozīmīgs kā galvenais vidēja termiṇa valsts attīstības plānošanas dokuments. Izvirzịtas trīs prioritātes; katrai prioritātei seko trīs līdz pieci rīcības virzieni: (1) tautas saimniecỉbas izaugsme, (2) cilvēka drošumspēja, (3) izaugsmi atbalstošas teritorijas. Personas ar invaliditāti pieminētas prioritātes "Cilvēka drošumspēja" rīcības virzienā "Cienīgs darbs": "(234) Ikkatram ir tiesības būt aktīvam, piedalīties sevis, sabiedrības un Latvijas attīstībā. Latvija atraisa arī to cilvēku potenciālu, kuri dzìvojuši sociālās aprūpes institūcijās, piedāvājot alternatīvas aprūpes formas, kas nodrošina iespēju îstenot cienīgu darbu tā plašākā nozīmē - dot un dalìties ar citiem un strādāt savu spēju ietvaros. Nepieciešams īpašu uzmanību pievērst cilvēku ar invaliditāti vajadzībām kā vienai no sociāli atstumtākajām sabiedrības grupām, domājot par to ciešāku integrāciju sabiedrībā kopumā un ippaši darba tirgū." (Saeima, 2013b, 37)

Tas, ka cilvēki ar invaliditāti "NAP 2020" pieminēti tikai vienā teikumā, gan nenozīmē, ka citas prioritātes un rīcības virzieni, kur šì iedzīvotāju grupa netiek īpaši izcelta, izslēdz no mērḳgrupas personas ar invaliditāti. Visas prioritātes un rīcības virzieni attiecināmi uz personām ar invaliditāti līdztekus visiem valsts iedzīvotājiem. 
- Sabiedrības veselības pamatnostādnes 2014.-2020. gadam (SV pamatnostādnes) (Saeima, 2013c)

Vidēja termiṇa politikas plānošanas dokuments. Nozīmīgs dokuments personām ar invaliditāti, jo, kaut arī ne vienmēr, tomēr invaliditāte nereti cieši saistīta ar veselības aprūpes nepieciešamību, būtiska ir tās pieejamība. Veselības aprūpe ir viens no SV pamatnostādṇu jautājumiem. SV pamatnostādņu ievadā īpaši uzsvērtas sociālās atstumtības un nabadzības riskam pakḷauto iedzīvotāju grupu, tātad arī personu ar invaliditāti, vajadzības: "Pamatnostādnes tika izstrādātas, lai turpinātu aizsāktās sabiedrības veselības politikas îstenošanu, kā arī aktualizētu jaunus attīstības mērķus un rīcības virzienus to sasniegšanai, saglabājot, uzlabojot un atjaunojot Latvijas iedzīvotāju, jo īpaši, sociālās atstumtības un nabadzības riskam pakḷauto iedzīvotāju, veselības stāvokli nākamajos septiņos gados." (4. lpp.)

SV pamatnostādnes piedāvā situācijas raksturojumu un problēmu formulējumu sabiedrības veselībā; definēti mērḳi, politikas un darbības rezultāti un rezultatīvie rādītāji. Viens rezultatīvais rādìtājs tieši sasaistīts ar invaliditātes jautājumu - pieaugušo pirmreizējā invaliditāte, visi cēloṇi.

- Pamatnostādnes sociālo pakalpojumu attīstībai 2014.-2020. gadam (SP pamatnostādnes) (Saeima, 2013d)

Sociālo pakalpojumu attīstības politika ir īpaši nozīmīga personām ar invaliditāti, jo no šo pakalpojumu pieejamības un kvalitātes lielā mērā ir atkarīgas izredzes izmantot visas cilvēktiesības un pamatbrīvības, kā to paredz ANO Konvencija. SP pamatnostādṇu ievadā teikts: "Pamatnostādṇu mērḳi un veicamie pasākumi ir virzīti uz to, lai nodrošinātu indivīda vajadzībām atbilstošu, sabiedrībā balstītu sociālo pakalpojumu sniegšanu, kas sekmē personas pašaprūpes iespējas un neatkarīgas dzīves iespējas, bet personām, kuru aprūpe prasa nepārtrauktu speciālistu uzraudzību - nodrošināt cienīgus dzīves apstākḷus un augstas kvalitātes pakalpojumus aprūpes institūcijās." (Saeima, 2013d, 5)

SP pamatnostādnēs iekḷauta pašreizējās situācijas analīze un identificēto problēmu apraksts, politikas mērḳi un pamatprincipi, politikas rezultāti un rezultatīvie rādītāji. Liela uzmanība vērsta uz ārpusǵimenes aprūpē esošo bērnu un personu ar invaliditāti situācijas uzlabošanu. Politikas rezultāti un rezultatīvie rādītāji ietver jauniešu māju un grupu māju skaitu, aprūpes pakalpojumu pieejamību mājās, dienas centru un dienas aprūpes centru pieejamību, sociālās rehabilitācijas un palīglīdzekḷ saṇēmušo skaitu, kā arī citus rādītājus. Viens no uzdevumiem ir Deinstitucionalizācijas (turpmāk - DI) plāna izstrāde, kas 2015. gadā ir paveikta; kopš 2017. gada aktīvi tiek realizēts rīcỉbas plāns.

Viena no iesaistītajām valsts institūcijām SP pamatnostādṇu realizācijā ir Sociālās integrācijas valsts aǵentūra, kas nodrošina profesionālās rehabilitācijas pakalpojumus. 
- Rīcības plāns deinstitucionalizācijas īstenošanai 2015.-2020. gadam (Labklājỉbas ministrija, 2015b)

Deinstitucionalizācija attiecībā uz personām ar invaliditāti ir Pasaules Veselības organizācijas (turpmāk - PVO) atbalstìts pasākums, kas sasaucas ar PVO Eiropas reg̣iona garīgās veselības Rìcỉbas plānu (World Health Organisation, 2013). DI plāns nozīmē arī svarīgu ES struktūrfondu līdzekḷu apguvi. Budžets tikai individuālo vajadzību izvērtēšanai un DI plāna izstrādei un ieviešanai ir vairāk nekā 47 miljoni eiro; DI infrastruktūras izveidei - vairāk nekā 44 miljoni eiro; tam papildus ir arī sinerğijas ar citām atbalsta sistēmām un pakalpojumiem (49. lpp). Tā kā DI plāna īstenošana balstās uz ES struktūrfondu līdzekḷu apguvi, būtiski ir nodrošināt veiksmīgu procesa tālāko attīstību, kad fondu līdzekḷi vairs nebūs pieejami.

DI plāna ievadā norādīts, ka "Deinstitucionalizācija ir pakalpojumu sistēmas izveide, kas sniedz personai, kurai ir ierobežotas spējas sevi aprūpēt, nepieciešamo atbalstu, lai tā spētu dzīvot mājās vai gimeniskā vidē. DI ir jānovērš situācija, ka personai ir jāpārceḷas uz dzīvi ilgstošas sociālās aprūpes un sociālās rehabilitācijas institūcijā (turpmāk - institūcija), jo tai nav pieejams nepieciešamais atbalsts dzīvesvietā jeb sabiedrībā balstīti pakalpojumi." (Labklājibas ministrija, 2015b, 3)

Periodā līdz 2020. gadam Latvijā DI prioritārās mērḳgrupas ir ārpusǵimenes aprūpē esošie bērni, bērni ar funkcionāliem traucējumiem, pilngadīgas personas ar garīga rakstura traucējumiem.

DI plāns ietver situācijas izvērtējumu, sasniedzamos rezultātus, darbības virzienus, plānu, kā novērtēt vajadzības pēc pakalpojumiem. Ir noteikti un aprakstīti šãdi galvenie darbības virzieni: DI procesa vadība; sabiedrïbas un speciālistu attieksmes maiņa; vajadzību pēc pakalpojumiem novērtējums; plānošanas reǵionu/pašvaldību situācijas analīze un nepieciešamo pakalpojumu plānošana; personāla apmācība, klientu sagatavošana pārejas procesam un sociālo pakalpojumu nodrošināšana dzìvesvietā/pašvaldībā; pašvaldību pakalpojumu infrastruktūras attīstība atbilstoši reǵionu DI plāniem; monitorings un novērtēšana.

DI process nav pasaulē jauns virziens. Piemēram, ASV šis process norisinājās 20. gs. 50. un 60. gados. Viens no mērḳiem toreiz bija pēc DI realizēšanas panākt izmaksu samazināšanu, meklēt lētākas alternatīvas institūcijām. DI ir saņēmis arī vērā ṇemamu kritiku, diskusija par šì procesa rezultātā radītajiem ieguvumiem un zaudējumiem joprojām ir aktuāla (Bagenstos, 2012; Perry, 2016; Lamb, Bachrach, 2001). Viens no kritikas argumentiem ir reāli darbojošos sabiedrībā balstîtu pakalpojumu trūkums. Šobrīd realizētajā DI plānā šādu pakalpojumu izveide ir viens no galvenajiem uzdevumiem; būtiski, lai tie turpinātu attīstīties un būtu ne mazāk pieejami arī pēc ES struktūrfondu līdzekḷu apguves perioda. Cits diskusiju jautājums ir cilvēku 
ar garīgas attīstības traucējumiem stigmatizācija (Pescosolido, 2013). Te izšķiroša nozīme ir sabiedrïbas attieksmei, kas ir viens no plānotajiem darbības virzieniem DI plānā. Trešais būtiskais kritikas arguments ir DI procesa un ieslodzījuma vietu statistikas rādītāju dinamikas saistība (Kim, 2014), kā arī bezpajumtnieku skaita pieaugums (Sisti, Segal, Emanuel, 2015). Pašreiz Latvijā notiekošais DI process ir balstitts uz PVO noteiktajiem principiem (World Health Organization, n.d.) un Eiropas Kopējām vadlīnijām, un Rokasgrāmatu par ES fondu izmantošanu, lai īstenotu pāreju no institucionālās aprūpes uz sabiedrībā balstītu pakalpojumu izveidi (European Commission, 2012). DI plānā viens no pamatprincipiem DI ìstenošanai personām ar garīga rakstura traucējumiem ir šāds: "Neatkarīga dzīve ar iespējām saņemt individuālajām vajadzībām atbilstošu atbalstu dzīvesvietā ir labākā izvēle - visiem iesaistītajiem speciālistiem ir jābūt vienotai izpratnei par to, cik negatīvu iespaidu uz personu atstāj aprūpe institūcijā, un ka funkcionālā traucējuma veids un smaguma pakāpe pati par sevi nevar būt iemesls sabiedrībā balstìto pakalpojumu iespēju izslēgšanai." (Labklājības ministrija, 2015b, 5)

Jācer, ka šeit minētā vienotā izpratne par institūciju negatīvo ietekmi atstāj vietu kritikai un ņem vērā dažādu valstu līdzšinējās pieredzes analīzi.

- Profesionālā sociālā darba attīstỉbas pamatnostādnes 2014.2020. gadam (SD pamatnostādnes) (Saeima, 2013e)

SD pamatnostādnes personām ar invaliditāti ir nozīmīgas, jo sociālā darba attīstība ir būtiska komponente sociālo pakalpojumu sniegšanā un saņemšanā. SD pamatnostādnēs, līdzīgi kā citos pamatnostādṇu dokumentos, ir analizēta situācija, definēti mērḳi, uzdevumi, politikas rezultāti, rezultatīvie rādītāji; SD pamatnostādnēs noteikti divi galvenie rīcības virzieni: 1) sociālā darba kvalitātes pilnveidošana, pieejamības nodrošināšana un efektivitātes paaugstināšana un 2) ilgtspējīga sociālā darba nozares attīstība.

SD pamatnostādnēs kā nozīmīgākais saistītais starptautiskais dokuments minēta Eiropas Sociālā harta (turpmāk - ESH) (Eiropas Padome, 1961). Lai gan Saeima ir pieņēmusi un Valsts prezidents 2001. gadā izsludinājis deklarāciju par ESH, tomēr Latvijai ESH 15. pants "Invalīdu un garīgi atpalikušu personu tiesības uz arodapmācību, rehabilitāciju un sociālo iekārtošanu" nav viens no šîs deklarācijas saistošajiem pantiem (Saeima, 2001b). Ar ANO Konvenciju, kas SD pamatnostādṇu izstrādes laikā jau bija ratificēta, kā arī DI plānu, kas vēl nebija izstrādāts (tomēr DI iestrādnes ir SP pamatnostādnēs), tieša saikne dokumentā nav norādīta, tomēr faktiski sociālā darba attīstìba attiecībā uz cilvēkiem ar invaliditāti lielā mērā ir saistīta ar tajos deklarētajiem principiem un uzdevumiem, kā arī izaicinājumiem, kam nepieciešami atbilstoši atbalsta rìki un pasākumi, kā arī pietiekams skaits sagatavotu sociālo darbinieku, kas spēj un ir gatavi rìkoties. 
- Izglítibas attīstības pamatnostādnes 2014.-2020. gadam (IA pamatnostādnes) (Izglītîbas un zinātnes ministrija, 2013)

IA pamatnostādnēs viens no apakšmērḳa "1. Izglìtības vide: paaugstināt izglitīibas vides kvalitāti, veicot satura pilnveidi un attīstot atbilstošu infrastruktūru” rīcības virzieniem ir "1.4. Iekḷaujošās izglìtības principa īstenošana un sociālās atstumtîbas riska mazināšana. Tiks veicināta agrīna, savlaicīga speciālo izglìitibas vajadzību diagnostika visās izglìīibas pakāpēs un veidos (izņemot augstāko izglìîibu), veicinot preventīvus pasākumus funkcionālo un speciālo vajadzību savlaicīgai kompensēšanai izglìīibas iestādēs (t. sk. pilnveidojot speciālo izglìīibas programmu un vajadzību klasifikāciju)".

Uzdevuma "Profesionālās izglîtības mācību vides uzlabošana atbilstoši tautsaimniecỉbas nozaru attīstỉbai" viens no pasākumiem ir "atbalsts būvdarbiem, iekārtu, aprīkojuma un tehnologiiju iegādei un izglīiîbas iestāžu pielāgošanai personām ar funkcionāliem traucējumiem" (Izglìīibas un zinātnes ministrija, 2013).

Aktuāls papildinājums šim dokumentam ir 2016. gadā izstrādātās "Izglîtības politikas prioritātes un veicamās reformas izglîtībā" (Izglītîbas un zinātnes ministrija, 2016). 2017. gada pavasarī medijos jau bija izskanējusi ziņa par speciālo skolu slēgšanu (Orupe, 2017). Reforma nozīmīga arī saistībā ar iekḷaujošās izglìtîbas principu realizēšanu augstākajā izglītībā un mūžizglîtību.

- Transporta attīstības pamatnostādnes 2014.-2020. gadam. (TA pamatnostādnes) (Saeima, 2013f)

TA pamatnostādnēs nav tiešu norāžu uz personu ar invaliditāti interesēm, tomēr dokuments nozīmīgs lauku reǵionu kontekstā, jo nosaka mērķus sabiedriskā transporta nodrošināšanai: "Apakšmērḳis/darbības virziens: nodrošināta iekšèjā un ārējā sasniedzamība, un augstas kvalitātes mobilitātes iespējas visā valsts teritorijā. Politikas rezultāts: nodrošināta iespēja visiem iedzīvotājiem nokḷūt novada centrā, apmeklēt izglìīibas iestādes, nokḷūt darba vietās, valsts un pašvaldību institūcijās to normālajā darba laikā ar sabiedrisko transportu. Rezultatīvais rādītājs: (1) pagastu īpatsvars, kur ir nodrošināti vismaz divi sabiedriskā transporta reisi dienā, kas savieno bijušos pagastu administrativos centrus ar novada centru; (2) novadu ipatsvars, kur ir nodrošināti vismaz divi reisi dienā, kas savieno novadus ar reğiona centru vai galvaspilsētu." (Saeima, 2013f)

Šiem pakalpojumiem, kas minēti rezultatīvajos rādītājos, kopš 2016. gada būtu jābūt nodrošinātiem simtprocentīgi.

Sabiedriskā transporta pieejamība cilvēkiem ar invaliditāti svarīga ne tikai kā konkrētais pakalpojums, ko jāvar izmantot līdzvērtīgi citiem valsts iedzīvotājiem, bet arī kā iespēja lietot citus sociālos pakalpojumus un atbalsta pasākumus. Lauku reǵionos būtisks ir ne tikai bijušo pagastu centru savienojums ar novada centru un tālāk ar reg̣iona centru vai galvaspilsētu, bet 
arī autocelı pārklājums ar sabiedriskā transporta maršrutiem, jo arī attālums līdz bijušajam novada centram var būt sabiedriskā transporta izmantošanas šḳērslis.

Par terminịiem sabiedriskā transporta pielāgošanai, lai personām ar funkcionāliem traucējumiem atvieglotu iekḷ̂ššnu sabiedriskajā transportā un nodrošinātu šo personu pārvadāšanu, jāskata MK noteikumi Nr. 599 "Sabiedriskā transporta pakalpojumu sniegšanas un izmantošanas kārtība": "Sabiedriskajam transportlīizeklim jābūt pielāgotam normatīvajos aktos par transportlīizekḷu izgatavošanu noteiktajām tehniskajām prasībām, lai personām ar funkcionāliem traucējumiem, grūtniecēm un personām ar maziem bērniem (tai skaitā ar bērnu ratiniem) atvieglotu iekḷuššnu sabiedriskajā transportlīdzeklī un nodrošinātu šo personu pārvadāšanu." (MK, 2012b, 17. punkts)

Termiņi atrunāti šo noteikumu 133., 134., 135. un 136. punktā, līdz 2024. gada 1. janvārim paredzot visu 17. punktā minēto prasību izpildi pilnā apmērā.

Sabiedriskā transporta pakalpojumu likums šai iedzīvotāju grupai atsevišķu uzmanību nepievērš. Tādējādi, runājot par sabiedriskā transporta pieejamību, kas ir nozīmīgs nosacỉjums personu ar invaliditāti cilvēktiesību un pamatbrīvību realizēšanai, MK noteikumi ir vienīgais regulējošais dokuments, kas attiecas uz plānotajiem pasākumiem sabiedriskā transporta pieejamības uzlabošanā personām ar invaliditāti; tādēḷ tas minēts politikas veidošanas dokumentu kontekstā.

Personas ar I un II grupas invaliditāti, bērni ar invaliditāti, kā arī personas, kuras pavada personu ar I grupas invaliditāti vai bērnu ar invaliditāti, drīkst pārvietoties regionālajos starppilsētu maršrutos, reǵionālajos vietējas nozīmes maršrutos vienā administratīvajā teritorijā, kā arī sabiedriskajā transportā pilsētas nozīmes maršrutos bez maksas (Satiksmes ministrija, b.g.).

\section{- Likumu un MK noteikumu pārskats (2. pielikums)}

Likumu un MK noteikumu pārskats veidots, lai apkopotu tos valsts likumus un MK noteikumus, kas attiecas uz personu ar invaliditāti tiesībām un sociālo pakalpojumu iespējām. Likumu un MK noteikumu saraksts dots 2. pielikumā "Likumi un MK noteikumi par personu ar invaliditāti tiesībām".

2010. gadā tika publicēts ekspertu grupas "Ziņojums par cilvēku ar funkcionāliem traucējumiem vajadzību ieḳ̣̂avumu nacionālos un reǵionālos plānošanas dokumentos" (Latvijas Kustība par neatkarīgu dzīvi, 2010); šobrīd situācija ir ievērojami mainījusies un būtu vēlams diskusiju turpināt jaunajos apstākḷos, stingri vērtējot ne tikai vajadzību ieḳ̣̂avumu, bet arī rezultatīvo rādìtāju atbilstību.

Šajā pielikumā skatīti politikas veidošanas dokumenti, kas ir nozīmīgi personu ar invaliditāti tiesību un brīvību realizēšanai. Papildus 2. pielikumā 
pievienots likumu un MK noteikumu pārskats. Skatītie politikas dokumenti ir svarīgi, jo atspoguḷo politisko diskursu un norāda uz esošo un plānoto rīcību personu ar invaliditāti situācijas uzlabošanai. Politikas veidošanā liela nozīme ir starptautiskajiem līgumiem un ar ES atbalstu virzītām politikas pārmaiṇām. Aktuālajam ES atbalstam sociālajai uzņēmējdarbībai vajadzētu sekmēt personu ar invaliditāti iesaisti darba tirgū, savukārt DI plāna īstenošanai - veicināt sociālo pakalpojumu un nepieciešamās infrastruktūras pieejamību, kā arī sabiedrības izpratni par personu ar invaliditāti situāciju. Labākai politikas realizēšanas uzraudzībai būtu nepieciešama funkcionējoša pārmaiṇu monitoringa nodrošināšana. 


\section{Likumi un MK noteikumi par personu ar invaliditāti tiesībām}

- Invaliditātes likums, stājies spēkā 01.01.2011. (Saeima, 2010a)

- Sociālo pakalpojumu un sociālās palīdzības likums, stājies spēkā 01.01.2003. (Saeima, 2002a)

- Valsts sociālo pabalstu likums, stājies spēkā 01.01.2003. (Saeima, 2002b)

- Likums "Par sociālo drošibu", stājies spēkā 05.10.1995. (Saeima, 1995c)

- Darba likums, stājies spēkā 01.06.2002. (Saeima, 2001a)

- Likums "Par maternitātes un slimības apdrošināšanu", stājies spēkā 01.01.1997. (Saeima, 1995b)

- Likums "Par valsts sociālo apdrošināšanu", stājies spēkā 01.01.1998. (Saeima, 1997b)

- Sociālā uzñēmuma likums, stājies spēkā 01.04.2018. (Saeima, 2017a)

- Ministru kabineta 2014. gada 23. decembra noteikumi Nr. 805 "Noteikumi par prognozējamas invaliditātes, invaliditātes un darbspēju zaudējuma noteikšanas kritērijiem, terminiiem un kārtïbu". (MK, 2014b)

- Ministru kabineta 2010. gada 28. decembra noteikumi Nr. 1207 "Noteikumi par personai ar prognozējamu invaliditāti prioritāri sniedzamo invaliditātes riska mazināšanai paredzēto pakalpojumu veidiem, apjomu, saņemšanas nosacijumiem un saņemšanas kārtïbu”. (MK, 2010b)

- Ministru kabineta 2011. gada 4. janvāra noteikumi Nr. 9 "Noteikumi par individuālo rehabilitācijas plānu personai ar prognozējamu invaliditāti un personai ar invaliditāti”. (MK, 2011a)

- Ministru kabineta 2014. gada 10. novembra noteikumi Nr. 698 "Noteikumi par pabalstu par asistenta izmantošanu personām ar I grupas redzes invaliditāti”. (MK, 2014a)

- Ministru kabineta 2012. gada 18. decembra noteikumi Nr. 942 "Kārtība, kādā pieškir un finansē asistenta pakalpojumu pašvaldībā". (MK, 2012d)

- Ministru kabineta 2012. gada 9. oktobra noteikumi Nr. 695 "Kārtība, kādā piešķir un finansē asistenta pakalpojumu izglítibas iestādē". (MK, 2012c)

- Ministru kabineta 2017. gada 21. februāra noteikumi Nr. 94 "Kārtība, kādā persona saṇem valsts finansētus profesionālās rehabilitācijas pakalpojumus un profesionālās piemērotības noteikšanas pakalpojumu". (MK, 2017)

- Ministru kabineta 2011. gada 1. marta noteikumi Nr. 170 "Noteikumi par darbības programmas "Cilvēkresursi un nodarbinātība" papildinājuma 
1.4.1.1.1. apakšaktivitāti "Kompleksi atbalsta pasākumi iedzīvotāju integrēšanai sabiedrībā un darba tirgū"”. (MK, 2011b)

- Ministru kabineta 2009. gada 31. marta noteikumi Nr. 279 "Noteikumi par kārtību, kādā personas saṇem sociālās rehabilitācijas pakalpojumus sociālās rehabilitācijas institūcijās, un prasībām sociālās rehabilitācijas pakalpojumu sniedzējiem". (MK, 2009a)

- Ministru kabineta 2012. gada 26. jūnija noteikumi Nr. 450 "Noteikumi par invaliditāti apliecinoša dokumenta paraugu, dokumenta izsniegšanas un uzskaites kārtỉbu". (MK, 2012a)

- Ministru kabineta 2009. gada 15. decembra noteikumi Nr. 1472 "Kārtỉba, kādā Latvijas Neredzīgo biedrība un Latvijas Nedzirdīgo savienība sniedz sociālās rehabilitācijas pakalpojumus un nodrošina tehniskos palīglīdzekl̦us - tiflotehniku un surdotehniku”. (MK, 2009b)

- Ministru kabineta 2010. gada 21. decembra noteikumi Nr. 1170 "Noteikumi par kārtîbu, kādā personas ar invaliditāti saņem atbalstu mājoḳ̣la pielāgošanai, un atbalsta saņemšanas nosacijumiem”. (MK, 2010a)

- Ministru kabineta 2012. gada 28. augusta noteikumi Nr. 599 "Sabiedriskā transporta pakalpojumu sniegšanas un izmantošanas kārtība”. (MK, 2012b)

- Ministru kabineta 2015. gada 16. jūnija noteikumi Nr. 313 "Darbỉbas programmas "Izaugsme un nodarbinātỉba" 9.2.2. specifiskā atbalsta mērķa "Palielināt kvalitatīvu institucionālai aprūpei alternatīvu sociālo pakalpojumu dzīvesvietā un gímeniskai videi pietuvinātu pakalpojumu pieejamību personām ar invaliditāti un bērniem" 9.2.2.1. pasākuma "Deinstitucionalizācija" īstenošanas noteikumi". (MK, 2015)

- Ministru kabineta 1997. gada 8. aprịla noteikumi Nr. 138 "Noteikumi par iedzìvotāju ienākuma nodokḷa papildu atvieglojumiem personām ar invaliditāti, politiski represētajām personām un nacionālās pretošanās kustības dalībniekiem". (MK, 1997)

- Ministru kabineta 2009. gada 22. decembra noteikumi Nr. 1605 "Noteikumi par valsts sociālā nodrošinājuma pabalsta un apbedǐšanas pabalsta apmēru, tā pārskatîšanas kārtỉbu un pabalstu pieškiršanas un izmaksas kārtību". (MK, 2009c) 

Sociālā spēcināšana rīcỉbspējai un pārmaiņām, 2019

LU Akadēmiskais apgāds Aspazijas bulv. 5, Rìga, LV-1050 www.lu.lv/apgads 
Pārskats par projektu "Sociālā spēcināšana regionos" (SEMPRE) Interreg Baltijas jūras reǵiona transnacionālās teritoriālās sadarbības programmā (2014-2020) ir adresēts profesionāl̦iem, sociālās politikas veidotājiem un interesentiem par sociālās labklājības jautājumiem. Pārskats sniedz ieskatu zināšanās par sociālo spēcināšanu, iesaistǐšanu un iesaistī̌sanos sociālos procesos visām tām personām, kas ieinteresētas sociālās dzīves procesos.

Pārskatā ir sniegta dažu sociālekonomiskā konteksta empīisko rādītāju salīdzinošā analīze, kā arī spēcināšanā iesaistīto un ieinteresēto pušu analīze par tām vietām, kurās SEMPRE projektā ir îstenota sociālo pakalpojumu sniedzēju un galalietotāju sociālā spēcināšana. Sadarbībā ar draudzīgo projekta partneri - Liepājas Diakonijas centru - Latvijā ir apzinātas personu ar invaliditāti vajadzības. Grāmatā ir aprakstītas vajadzību apzināšanas metodes, kas tiek lietotas Ziemel̦eiropā, un iekl̦auti daudzi piemēri par Eiropas Savienības astoṇu Baltijas jūras reǵiona valstu sociālās spēcināšanas labo praksi.

Informācija par projektu atrodama interneta vietnē www.sempre-project.eu.
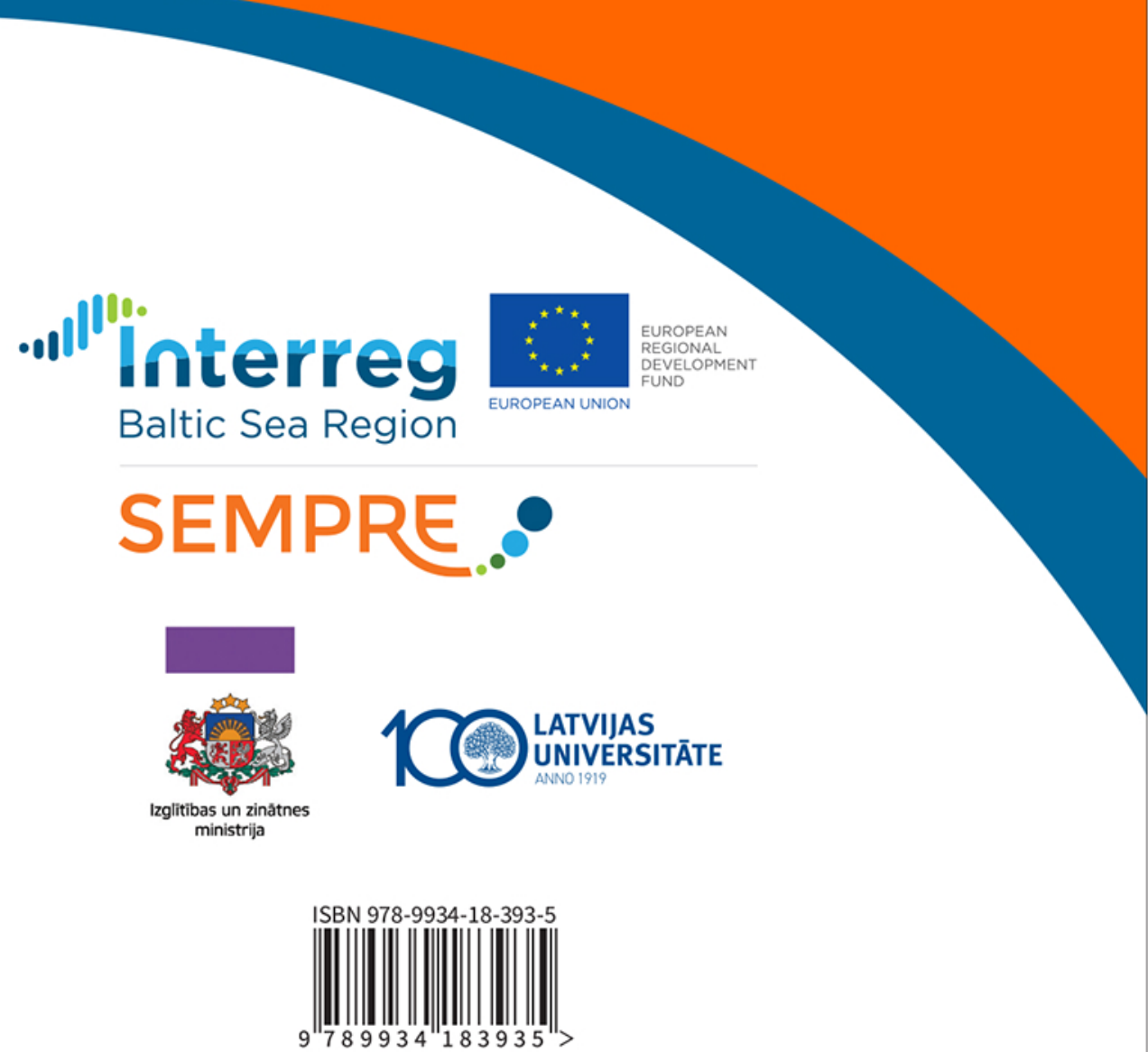